Daniel Lino Teodoro

\title{
Aprendizagem em Grupos Cooperativos e Colaborativos: Investigação no Ensino Superior de Química
}

Tese apresentada ao Instituto de Química de São Carlos da Universidade de São Paulo como parte dos requisitos para a obtenção do título de Doutor em Ciências.

Área de Concentração: Química Analítica e Inorgânica

Orientadora: Profa. Dr ${ }^{a}$. Salete Linhares Queiroz

\section{Exemplar revisado}

O exemplar original encontra-se em acervo reservado na Biblioteca do IQSC-USP

São Carlos 



\section{Dedicatória}

Dedico este trabalho à minha mãe Maria e à minha esposa Graziela, pelo amor, carinho e incentivo; aos meus irmãos Marcio, Elizangela e Gisele, pelo apoio e participação em todas as etapas da minha vida e que com seus filhos ajudaram a dar sentido a minha vida. In memoriam de Willian F. Teodoro, a parte que me faz mais forte. 



\section{AGRADECIMENTOS}

À minha orientadora Profa. Dra. Salete Linhares Queiroz, por ter me guiado pelos melhores caminhos, ajudando-me a superar as dificuldades, sem deixar de me desafiar a ser melhor a cada dia; é para mim a melhor definição da palavra orientar.

À minha mãe Maria E. Barbosa, que nunca me deixa esquecer que sempre há um próximo passo, um próximo pensamento, uma próxima ação que podem me tornar uma pessoa ainda melhor; que não se limitou a dizer o que eu devia fazer, pelo contrário, realizou ações que me inspiraram e não se negou a estar do meu lado só por estar.

À minha esposa Graziela Joskowicz, por ser capaz de me fazer sorrir e me animar mesmo quando a força me falta, por me fazer entender que amar não é só esperar e ter paciência e sim deixar seus sonhos de lado para sustentar a pessoa que se ama.

À minha irmã Gisele L. Teodoro pela coragem e amor que contagia e me faz sentir protegido sempre e ao meu cunhado Domenico por cuidar de pessoas que eu amo tanto.

À minha sobrinha Larissa L. Negreli e ao meu sobrinho Anderson Gabriel de S. Barbosa, por me fazerem querer ser melhor, por refletirem nos outros parte do que eu tenho de melhor.

À minha irmã Elisagela G. Teodoro pelo exemplo de vida, por me fazer querer ser igual a ela, por sonhar com um amanhã diferente para nós e ao meu cunhado Alexandre por cada vez mais fazer parte da minha história e por tantas vezes ter estendido a mão quando eu precisei.

Ao meu irmão Antônio Marcio Barbosa, que mesmo distante ainda me inspira a lutar; será sempre meu grande herói e à minha cunhada Rosalina, que com seus filhos me ajudaram a encontrar sentido em continuar lutando. 
À minha tia Irene B. Gomes, que tanto ajudou na minha formação e como um anjo está sempre pronta a me proteger.

Aos meus amigos Leonardo Eidi. O. Iwaki, Jarlem J. Nacimento, Josué F. Teodoro e Vitor Godoy, que sempre estiveram do meu lado, que abdicaram de parte de suas histórias para me ajudar a construir um sonho, por cada madrugada que deixaram de dormir para me ajudar; saibam que sem vocês não teria chegado até aqui.

Aos meus sobrinhos Laura Nesci, Lucas, Enzo e Rafael dos Santos, que mesmo sem entenderem o motivo da distância continuaram a me motivar pelo simples fato de existirem.

Aos meus amigos Adilson, João Claudio, Henrique e a todos meus familiares por acreditarem na minha capacidade.

Aos meus colegas do Grupo de Pesquisa em Ensino de Química do Instituto de Química de São Carlos (GPEQSC), em especial Patrícia Cabral, Nilcimar Souza, Jerino Ferreira, Jane de Oliveira e Keila, meu fio de esperança, que por dois anos me lembrou que ainda não era hora de desistir.

Ao professor Daniel Luiz Carvalho, que com suas aulas inspirou-me a sonhar com os primeiros passos desta caminhada.

Aos professores Fergus Gessner e Joelma Perez por acreditarem no projeto de pesquisa e confiarem no meu trabalho.

Ao Instituto de Química de São Carlos (IQSC), da Universidade de São Paulo, pela estrutura oferecida aos alunos de doutorado.

Aos alunos do IQSC que contribuíram com esta pesquisa, participando da coleta de dados como sujeitos da pesquisa. 
"Quem se arrisca a dar um passo maior que a perna descobre que o mundo é capaz de colocar muros em sua frente. Porém, é feliz aquele que não teme muros, acha saídas e vive disposto a aprender a voar". (Autoria própria) 



\section{RESUMO}

Considerando a complexidade e a importância da discussão sobre atividades didáticas apoiadas em discussões em grupo, esta tese descreve atividades cooperativas (formato jigsaw) e colaborativas (formato Peer-Led Team Learning) realizadas no Curso de Bacharelado em Química do Instituto de Química de São Carlos, Universidade de São Paulo. As atividades cooperativas foram aplicadas nas disciplinas Comunicação e Expressão em Linguagem Científica I e Introdução à Química e as atividades colaborativas nas disciplinas Introdução à Química e Cinética Química. A dinâmica das interações discursivas estabelecidas entre os alunos nos grupos cooperativos e colaborativos foi investigada com base no Modelo Analítico proposto por Kumpulainen e Mutanen, a partir da análise das seguintes dimensões: funções da fala, processamento cognitivo e processamento social. Nessa perspectiva, foi estudada a influência do grau de estruturação das atividades e a natureza específica das disciplinas na dinâmica das interações discursivas. Nos grupos cooperativos as características peculiares dos conteúdos ministrados nas duas disciplinas direcionam a forma como os alunos usam as funções de fala, o que influencia diretamente a segunda e a terceira dimensão de análise. Nestas dimensões o processamento social predominante foi do tipo colaborativo e o processamento cognitivo predominante foi do tipo rotineiro. Nos grupos colaborativos ficou evidenciado que, independentemente da natureza das duas disciplinas, o uso das funções de fala foi bastante semelhante. Entretanto, o mesmo não ocorre para as demais dimensões. No que se refere ao processamento cognitivo, este apresentou principalmente característica rotineira, embora com considerável contribuição do tipo off-task, que atrapalhou as ações de alguns grupos. Este contexto foi corroborado pelos resultados encontrados para o processamento social, que apresentou características individualistas em todos os grupos. Os resultados obtidos apontam para a possibilidade de adaptação de ambos os tipos de atividades a distintas disciplinas do Curso, assim como destacam ressalvas e oferecem sugestões quanto à aplicação das mesmas no Ensino Superior de Química.

Palavras-Chave: Interações Discursivas. Jigsaw. PLTL. Química. Ensino Superior. 



\begin{abstract}
Considering the complexity and the importance of discussing teaching activities in group discussions, this thesis describes cooperative (jigsaw) and collaborative activities (Peer-Led Team Learning) carried out in the BSc degree in Chemistry at the Institute of Chemistry of São Carlos, the University of São Paulo, Brazil. The cooperative activities were used in the courses Communication and Expression in Scientific Language I and Introduction to Chemistry. The collaborative activities were used in the courses Introduction to Chemistry and Chemical Kinetics. The dynamics of discursive interactions established among students in the cooperative and collaborative groups was investigated based on the Analytical Model proposed by Kumpulainen and Mutanen, by analysing the following: functions of speech, cognitive processing and social processing. In this perspective, the influence of the level of structure of the activities was studied and the specific nature of the subjects in the dynamics of discursive interactions. In cooperative groups, the particular characteristics of the content taught in both courses show how students use functions of speech, which directly influence the second and third dimension of analysis. In these dimensions, the prevailing social process was collaborative and the predominant cognitive processing was routine. In collaborative groups, it was clear that regardless of the nature of the two courses, using functions of speech was quite similar. However, this is not true for the other dimensions. Regarding cognitive processing, it mainly showed the routine characteristic, although considerably contributing to off-task, which impaired some groups' actions. This context was corroborated by the results found for social processing, which showed individualist characteristics in all groups. The results obtained point to the possibility of adapting both types of activities in different courses on the Program, as well as highlighting exceptions and offering suggestions concerning using them in Higher Education Chemistry courses.
\end{abstract}

Keywords: Discursive interactions. Jigsaw. PLTL. Chemistry. Higher Education. 



\section{LISTA DE FIGURAS}

Figura 1 - Quantidade de trabalhos sobre aprendizagem cooperativa (APCP) e aprendizagem colaborativa (APCL) localizados no âmbito internacional.

Figura 2 - Distribuição dos trabalhos sobre aprendizagem cooperativa (APCP) e aprendizagem colaborativa (APCL) de acordo com os níveis de escolaridade.........39

Figura 3 - Classificação dos trabalhos de acordo com a área investigada ................42

Figura 4 - Quantidade de trabalhos publicados nas revistas e nos anais dos ENPEC

Figura 5 - Quantidade de trabalhos publicados nas revistas.

62

Figura 6 - Quantidade de trabalhos publicados nos anais dos ENPEC

Figura 7 - Distribuição dos trabalhos de acordo com as regiões brasileiras

Figura 8 - Distribuição dos trabalhos de acordo com as áreas de pesquisa. 66

Figura 9 - Distribuição dos trabalhos de acordo com o nível de escolaridade

Figura 10 - Esquema de formação de pequenos grupos de discussão pelo método jigsaw adaptado de Barbosa e Jófili (2004).

Figura 11 - Apresentação dos grupos de base, cada grupo composto por cinco alunos, cada um com um tipo de documento.

Figura 12 - Constituição do grupo de especialistas em artigos de divulgação científica.

Figura 13 - Apresentação dos grupos de base, cada grupo composto por cinco alunos, cada um com um tipo de documento. 103

Figura 14 - Constituição dos grupos de especialistas nas temáticas específicas da disciplina Introdução a Química. 104

Figura 15 - Porcentagem de uso dos processamentos cognitivos durante a resolução da primeira e terceira atividades nos Grupos 1 e 2 da Turma A (a) e da Turma C (b), com AT1 = primeira atividade e AT3= terceira atividade.

Figura 16 - Porcentagem de uso dos processamentos cognitivos sociais durante a resolução das três atividades dos Grupos 3 e 4 da Turma $C$ (a) e das três atividades do Grupos 1 da Turma B (b), AT1= primeira atividade e AT3= terceira atividade...134

Figura 17 - Porcentagem de uso dos processamentos cognitivos durante a resolução das três atividades do Grupo 1 da Turma B (a) e das três atividades dos Grupos 3 (b) e Grupos 4 (c) da Turma C, sendo AT1= primeira atividade, AT2= segunda atividade e AT3= terceira atividade. 
Figura 18 - Porcentagem de uso dos processamentos sociais durante a resolução das três atividades do Grupo 1 da Turma B (a) e das três atividades do Grupo 3 (b) e Grupo 4 (c) da Turma C, AT1= primeira atividade, AT2= segunda atividade e AT3= terceira atividade.

Figura 19 - Porcentagem de uso dos processamentos cognitivos durante a resolução das três atividades cooperativas nos Grupo 1 e 2 da Turma $C$ (a) e das três atividades colaborativas nos Grupos 3 e 4 da Turma C (b) 171

Figura 20 - Porcentagem de uso dos processamentos sociais durante a resolução das três atividades dos Grupos 1 e 2 cooperativos (a) e das três atividades dos Grupos 3 e 4 colaborativos (b), AT1= primeira atividade e AT3= terceira atividade. 


\section{LISTA DE TABELAS}

Tabela 1 - Revistas internacionais analisadas, períodos em que o levantamento foi realizado e a quantidade de trabalhos localizados em cada uma delas 32

Tabela 2 - Artigos sobre aprendizagem cooperativa sombreados e artigos sobre aprendizagem colaborativa não sombreados, localizados nas revistas internacionais analisadas e seu respectivo ano de publicação.

Tabela 3 - Classificação dos trabalhos de acordo com a área de pesquisa, nível educacional e foco temático, em que $\mathrm{F}=$ Fundamental, $M=$ Médio, $S=$ Superior e $\mathrm{G}=\mathrm{Geral}$

Tabela 4 - Revistas nacionais analisadas, os respectivos períodos em que o levantamento foi realizado e a quantidade de trabalhos localizados em cada uma delas.

Tabela 5 - Artigos sobre aprendizagem cooperativa sombreados e artigos sobre aprendizagem colaborativa não sombreados, localizados em revistas brasileiras ...56

Tabela 6 - Trabalhos completos apresentados nos ENPEC sobre aprendizagem cooperativa sombreados e artigos sobre aprendizagem colaborativa não sombreados. .58

Tabela 7 - Classificação dos trabalhos de acordo com a instituição de origem 61

Tabela 8 - Classificação dos trabalhos de acordo com a área de pesquisa, nível educacional e foco temático, em que $F=$ Fundamental, $M=$ Médio, $S=$ Superior e $G$ $=$ Geral 



\section{LISTA DE QUADROS}

Quadro 1 - Diferenças e semelhanças entre as aprendizagens colaborativa e cooperativa.

Quadro 2 - Categorização e descrição das funções de falas (adaptação do trabalho de Kumpulainen e Mutanen (1999)).

Quadro 3 - Categorização e descrição dos processamentos cognitivos.

Quadro 4 - Trecho do mapa analítico das interações ocorridas na primeira atividade do Grupo 1 da Turma C. Exemplificação das unidades de análises que constituem o mapa. 108

Quadro 5 - Trechos do mapa analítico das interações ocorridas na terceira atividade do Grupo 1 da Turma C, exemplificando as funções de fala pertencentes ao primeiro bloco.

Quadro 6 - Trechos do mapa analítico das interações ocorridas na primeira atividade do Grupo 1 da Turma A, exemplificando as funções de fala pertencentes ao segundo bloco.

Quadro 7 - Trechos do mapa analítico das interações ocorridas na primeira atividade do Grupo 2 da Turma C, exemplificando as funções de fala pertencentes ao terceiro bloco.

Quadro 8 - Distribuição das funções de fala para os grupos de base jigsaw na primeira e terceira atividades dos grupos da Turma A e da Turma C.

Quadro 9 - Trechos do mapa analítico das interações ocorridas na primeira atividade do Grupo 1 da Turma A (Fragmento 9) e na primeira atividade do Grupo 1 da Turma C (Fragmento 10). 116

Quadro 10 - Trechos do mapa analítico das interações ocorridas na primeira atividade do Grupo 1 da Turma A (Fragmento 11) e na primeira atividade do Grupo 1 da Turma C (Fragmento 12).

Quadro 11 - Trechos do mapa analítico das interações ocorridas na primeira atividade do Grupo 2 da Turma A (Fragmento 13) e na primeira atividade do Grupo 1 da Turma C (Fragmento 14).

Quadro 12 - Trechos do mapa analítico das interações ocorridas na primeira atividade do Grupo 1 da Turma C (Fragmento 15). 120

Quadro 13 - Trechos do mapa analítico das interações ocorridas na terceira atividade do Grupo 2 da Turma C (Fragmento 16) e na primeira atividade do Grupo 2 da Turma A (Fragmento 17).

Quadro 14 - Trechos do mapa analítico das interações ocorridas na primeira atividade do Grupo 1 da Turma C (Fragmento 18) e na primeira atividade do Grupo 2 da Turma A (Fragmento 19). 
Quadro 15 - Trechos do mapa analítico das interações ocorridas na primeira atividade do Grupo 2 da Turma A (Fragmento 20) e na terceira atividade do Grupo 1 da Turma C (Fragmento 21).

Quadro 16 - Trechos do mapa analítico das interações ocorridas na primeira atividade do Grupo 1 e terceira atividade do Grupo 2 da Turma A (Fragmentos 22 e 23), e na primeira atividade do Grupo 1 e do Grupo 2 da Turma C (Fragmentos 24 e 25).

Quadro 17 - Trechos do mapa analítico das interações ocorridas na primeira atividade do Grupo 1 da Turma C, exemplificando os processamentos cognitivos: Rotineiro (Fragmento 26), Off-task (Fragmento 27), Exploratório (Fragmento 28). 126

Quadro 18 - Trechos do mapa analítico das interações ocorridas na terceira atividade do Grupo 1 (Fragmento 29) e do Grupo 2 (Fragmento 30) da Turma A. . 129

Quadro 19 - Trechos do mapa analítico das interações ocorridas na primeira (Fragmento 31) e na terceira (Fragmento 32) atividade do Grupo 2 da Turma C, exemplificando o uso do processamento cognitivo rotineiro nessa turma. 130

Quadro 20 - Trechos do mapa analítico das interações ocorridas na primeira (Fragmento 33) e na terceira atividade (Fragmento 34) do Grupo 1 da Turma C, exemplificando o uso do processamento cognitivo exploratório nessa turma. 131

Quadro 21 - Trechos do mapa analítico das interações ocorridas na primeira atividade do Grupo 1 (Fragmento 35) e na terceira atividade do Grupo 2 (Fragmento 36) da Turma A, exemplificando o uso do processamento cognitivo exploratório nessa turma. 132

Quadro 22 - Trechos do mapa analítico das interações ocorridas na primeira (Fragmento 37) e na terceira (Fragmento 38) atividade do Grupo 1 da Turma C, exemplificando momentos que geraram processamentos sociais do tipo individualista. 135

Quadro 23 - Distribuição das funções de fala para os Grupos PLTL, nas três atividades do Grupo 1 da Turma B e nas três atividades dos Grupos 3 e 4 da Turma C. 141

Quadro 24 - Trechos do mapa analítico das interações ocorridas na primeira atividade do Grupo 1 da Turma B (Fragmento 39). 142

Quadro 25 - Trecho do mapa analítico das interações ocorridas na segunda atividade do Grupo 3 da Turma C (Fragmento 40). 143

Quadro 26 - Trechos do mapa analítico das interações ocorridas na primeira atividade do Grupo 1 da Turma B (Fragmento 41) e na primeira atividade dos Grupos 3 e 4 da Turma C (Fragmentos 42 e 43). 144

Quadro 27 - Trechos do mapa analítico das interações ocorridas na segunda atividade do Grupo 1 da Turma B (Fragmentos 44 e 45). 
Quadro 28 - Trechos do mapa analítico das interações ocorridas na segunda atividade do Grupo 1 da Turma B (Fragmento 46) e na segunda atividade do Grupo 3 da Turma C (Fragmento 47).

Quadro 29 - Trechos do mapa analítico das interações ocorridas na terceira atividade e na segunda atividade do Grupo 1 da Turma B (Fragmentos 48 e 49). . 149

Quadro 30 - Trechos do mapa analítico das interações ocorridas na segunda atividade do Grupo 3 da Turma C (Fragmentos 50 e 51). 150

Quadro 31 - Trechos do mapa analítico das interações ocorridas na primeira e segunda atividade do Grupo 1 da Turma B (Fragmentos 52 e 53). 154

Quadro 32 - Trecho do mapa analítico das interações ocorridas na terceira atividade do Grupo 1 da Turma B (Fragmento 54).

Quadro 33 - Distribuição das funções de fala para os grupos cooperativos e para os grupos colaborativos nas atividades da Turma C. 163

Quadro 34 - Trechos do mapa analítico das interações ocorridas na primeira atividade cooperativa do Grupo 1 (Fragmento 55) e na primeira atividade colaborativa do Grupo 3 (Fragmento 56). 164

Quadro 35 - Trechos do mapa analítico das interações ocorridas na terceira atividade cooperativa do Grupo 1 (Fragmento 57 ) e na terceira atividade cooperativa do Grupo 2 (Fragmento 58). 169

Quadro 36 - Trechos do mapa analítico das interações ocorridas na terceira atividade colaborativa do Grupo 4 (Fragmento 59) e da terceira atividade cooperativa do Grupo 2 (Fragmento 60). 173

Quadro 37 - Trechos do mapa analítico das interações ocorridas na segunda atividade do Grupo 3 da Turma C (Fragmento 61). 



\section{SUMÁRIO}

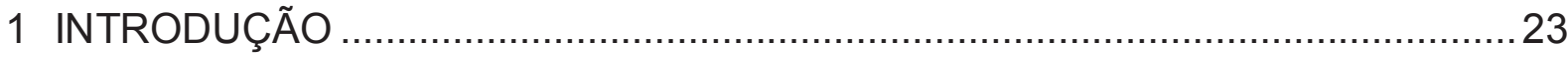

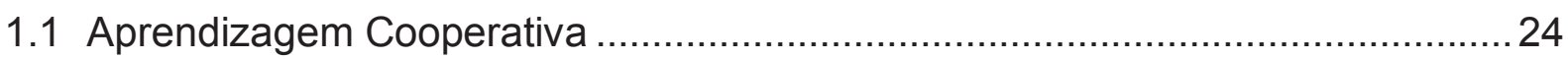

1.2 Aprendizagem Colaborativa ............................................................ 28

1.3 Aprendizagem Cooperativa e Colaborativa no Ensino de Ciências: Panorama das Pesquisas Nacionais e Internacionais ................................................... 30

1.3.1 Aprendizagem Cooperativa e Colaborativa: Âmbito Internacional ...................31

1.3.2 Aprendizagem Cooperativa e Colaborativa: Âmbito Nacional.........................55

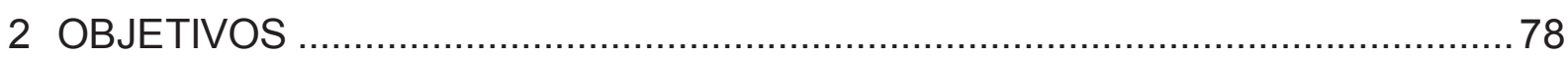

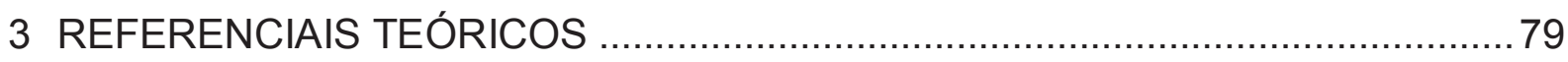

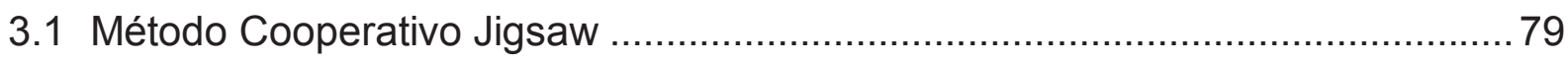

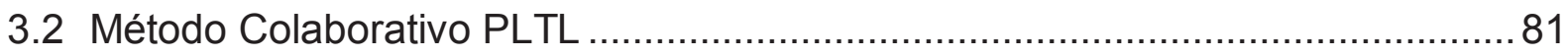

3.3 Modelo Analítico de Kumpulainen e Mutanen................................................... 84

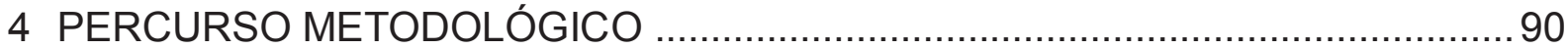

4.1 Contexto de aplicação das atividades em pequenos grupos na Turma A.........91

4.2 Contexto de aplicação das atividades em pequenos grupos na Turma B ..........96

4.3 Contexto de aplicação das atividades em pequenos grupos na Turma C..........99

4.3.1 Atividade Formato Jigsaw ............................................................. 101

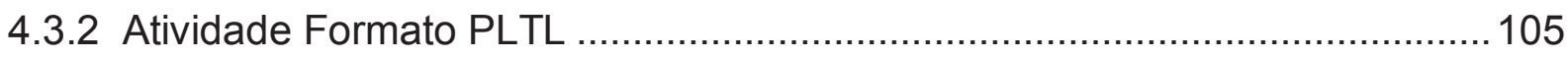

4.4 Métodos de registro dos dados ................................................................ 107

5 RESULTADOS E DISCUSSÃO ........................................................... 111

5.1 Influência da natureza das disciplinas na dinâmica das interações discursivas em grupo cooperativo jigsaw

5.1.1 Análise das interações discursivas na perspectiva da primeira dimensão: função de fala

5.1.2 Análise das interações discursivas na perspectiva da segunda dimensão:

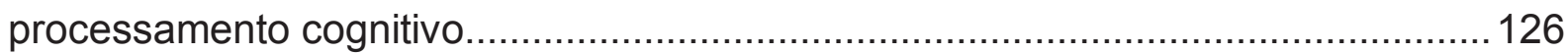

5.1.3 Análise das interações discursivas na perspectiva da terceira dimensão: processamento social.

5.2 Influência da natureza das disciplinas na dinâmica das interações discursivas em grupo colaborativo PLTL

5.2.1 Análise das interações discursivas na perspectiva da primeira dimensão: função de fala 
5.2.2 Análise das interações discursivas na perspectiva da segunda dimensão: processamento cognitivo

5.2.3 Análise das interações discursivas na perspectiva da terceira dimensão: processamento social

5.3 Influência do grau de estrutura da atividade de pequeno grupo na dinâmica das interações discursivas em uma mesma disciplina

5.3.1 Análise das interações discursivas na perspectiva da primeira dimensão: função de fala

5.3.2 Análise das interações discursivas na perspectiva da segunda dimensão: processamento cognitivo

5.3.3 Análise das interações discursivas na perspectiva da terceira dimensão: processamento social

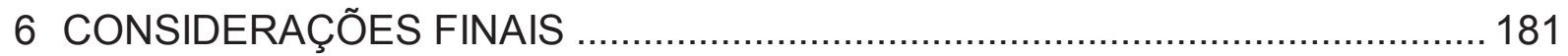

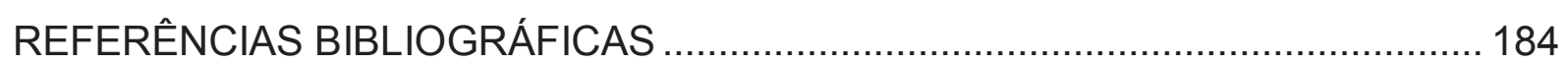

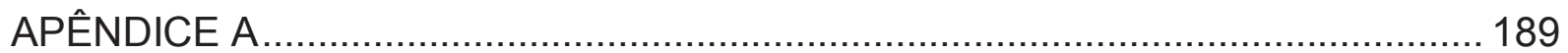

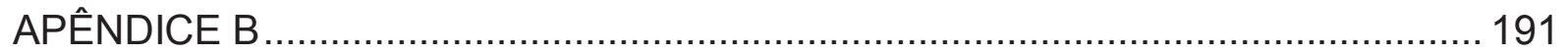

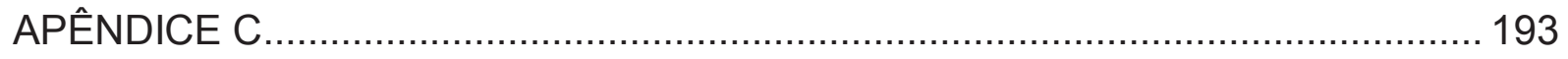

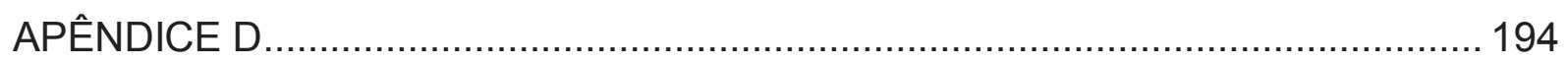

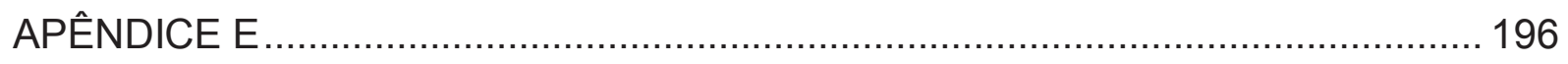

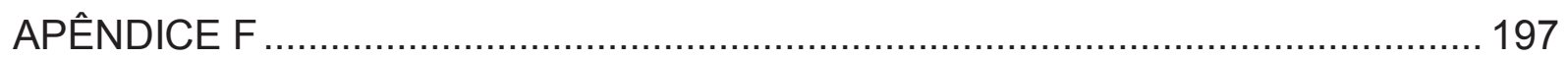

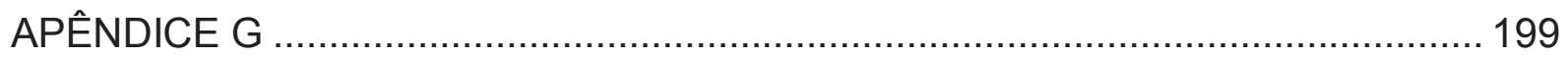

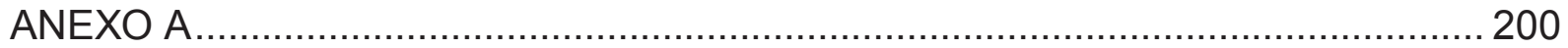

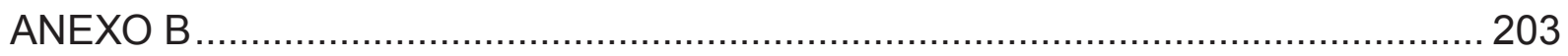




\section{INTRODUÇÃO}

Nos últimos anos, inúmeras modificações foram realizadas nas grades curriculares dos cursos de graduação em Química no Brasil. Contudo, como é destacado nas Diretrizes Curriculares Nacionais para os Cursos de Química, muitas se limitaram à inclusão de novas disciplinas, extinção de outras ou apenas remanejamento das grades curriculares (ZUCCO; PESSINE; ANDRADE, 1999).

Dessa forma, as modificações efetuadas não se mostraram capazes de atender à necessidade, advogada nas Diretrizes Curriculares Nacionais, do estabelecimento de "um novo modelo de curso superior, que privilegie o papel e a importância do estudante no processo da aprendizagem, em que o papel do professor, de 'ensinar coisas e soluções', passe a ser 'ensinar o estudante a aprender coisas e soluções'” (ZUCCO; PESSINE; ANDRADE, 1999, p. 454).

No modelo almejado, a escola tem responsabilidades que vão além da aprendizagem de conteúdo específico, buscando-se uma formação mais geral do estudante, com a inclusão de questões que envolvem a cidadania. Nesse contexto, as estratégias de trabalho em pequenos grupos surgem como alternativa que pode auxiliar no alcance de tal formação, tornando o aluno parte mais ativa no processo de ensino-aprendizagem. Tal participação está diretamente relacionada à interação existente entre os alunos, assim como entre eles e os docentes.

Buscando aprimorar as habilidades sociais e contribuir para o desenvolvimento de um novo modelo de ensino, diversos pesquisadores (COCHITO, 2004; BARBOSA; JÓFILI, 2004; JOHNSON; JOHNSON; SMITH, 2007; VALVERDE; VIZA, 2008) têm registrado diferentes formas de como trabalhar com pequenos grupos, em diversos formatos, com diferentes graus de estruturação, propondo diretrizes para a realização de atividades dessa natureza. Os resultados reportados nesses estudos levam-nos a crer que a realização de atividades em pequenos grupos pode contribuir ao alcance de algumas das habilidades apontadas como essenciais para a formação do químico, expressas nas Diretrizes Curriculares Nacionais (ZUCCO; PESSINE; ANDRADE, 1999).

Nessa perspectiva, analisamos neste trabalho atividades didáticas pautadas no trabalho em pequenos grupos, usando estratégias cooperativas e colaborativas, mais especificamente nos formatos jigsaw e PLTL. 
É importante ressaltar que, apesar de possuírem definições similares, os termos aprendizagem colaborativa e aprendizagem cooperativa apresentam diferenças nas perspectivas teóricas e práticas. Tendo em vista essas diferenças, apresentamos, a seguir, alguns dos fundamentos da aprendizagem cooperativa e da aprendizagem colaborativa.

\subsection{Aprendizagem Cooperativa}

Pode-se atribuir a divulgação da aprendizagem cooperativa aos autores David Johnson e Roger Johnson (1989), que foram responsáveis por inúmeras pesquisas e por vários registros sobre a temática. A característica chave que distingue a aprendizagem cooperativa da aprendizagem tradicional é a sua natureza social, pois proporciona uma maior interação entre os estudantes e o compartilhamento das ideias, aprimorando sua compreensão individual e mútua. Essa aprendizagem dá-se em um meio social particular, no qual se desenvolvem habilidades intelectuais e sociais, ao mesmo tempo em que há o estabelecimento de inter-relações sociais.

Uma vez que cooperar significa "trabalhar juntos para buscar objetivos comuns", pode-se esperar que, nas atividades cooperativas, os indivíduos buscam resultados que tragam benefícios para si mesmos e, simultaneamente, para todos os demais membros do grupo. A aprendizagem cooperativa faz uso de pequenos grupos, dando condição para os estudantes trabalharem juntos para poder melhorar seu próprio aprendizado e dos outros integrantes do grupo.

Seguindo a base teórica fornecida por Johnson, Johnson e Holubec (1999), para que o trabalho cooperativo seja funcional e produtivo, as seguintes condições precisam estar presentes no processo de ensino-aprendizagem:

- Interdependência positiva: o sentimento do trabalho conjunto para um objetivo comum em que cada um se preocupa com a aprendizagem dos colegas. Esta pode ser estimulada estabelecendo-se interdependência positiva de objetivos (os estudantes estão cientes de que os seus objetivos de aprendizagem só serão alcançados se todos os membros do grupo alcançarem as suas metas); interdependência positiva de recompensa (cada estudante recebe uma mesma recompensa quando o grupo alcança seus objetivos); interdependência positiva de recursos (cada estudante dispõe de apenas uma 
parte dos recursos, da informação ou dos materiais necessários para concluir a tarefa estabelecida pelo professor); interdependência positiva de papéis (aos estudantes são atribuídos papéis complementares e inter-relacionados, com responsabilidades necessárias para que o grupo realize a tarefa estabelecida pelo professor);

- Responsabilidade individual: cada elemento do grupo sente-se responsável pela sua própria aprendizagem e pela dos colegas e contribui ativamente para o grupo. Esta pode ser estimulada com a formação de grupos pequenos de aprendizagem (quanto menor for o grupo, maior será a responsabilidade individual); com a realização de avaliações individuais com cada aluno e de avaliações aleatórias com o grupo, fazendo com que um aluno, escolhido pelo mecanismo de sorteio, apresente o trabalho do grupo; por meio da atribuição a um dos membros do grupo do papel de "verificador", o qual deve solicitar aos demais que expliquem as razões que fundamentam as respostas dadas à tarefa estabelecida pelo professor; criar condições para que os estudantes ensinem aos companheiros o que aprendem, prática denominada pelos autores de "explicação simultânea";

- Interação face-a-face: oportunidade de interagir com os colegas de modo a explicar, elaborar e relacionar conteúdos. Esta permite aos estudantes estimular e facilitar os esforços dos demais membros do grupo visando ao alcance dos objetivos estabelecidos;

- Habilidades interpessoais: competências de comunicação, confiança, liderança, decisão e resolução de conflito. Toda a estruturação de atividades cooperativas baseia-se na premissa de que as habilidades sociais são a chave da produtividade do grupo (JOHNSON; JOHNSON; HOLUBEC, 1999). Quanto mais hábeis socialmente forem os alunos e mais atenção dispensem os professores ao ensino de habilidades sociais, maior será a possibilidade de sucesso do grupo;

- Processamento grupal: balanços regulares e sistemáticos do funcionamento do grupo e da progressão nas aprendizagens. Tem como objetivo avaliar quais ações do grupo se mostraram úteis e quais foram inúteis, conduzindo à elaboração de considerações sobre quais condutas devem ser mantidas ou alteradas. 
O domínio e a aplicação dos referidos componentes são pré-requisitos básicos para permitir que o docente formule e organize as atividades cooperativas formais, nas quais os alunos podem trabalhar por um dia ou por várias semanas, realizando diversas tarefas, que podem consistir, por exemplo, na resolução de um problema, na redação de um relatório ou na leitura de um texto. Inicialmente, são delegadas ao docente as seguintes atribuições: definir os objetivos da atividade; tomar decisões prévias à sua realização, como distribuir os estudantes nos seus grupos de trabalho, selecionar os materiais didáticos que serão usados, determinar a disposição de carteiras que será adotada para a atividade; explicar a atividade e os objetivos almejados para os estudantes participantes; colocar em prática a atividade cooperativa propriamente dita; verificar a efetividade do trabalho realizado pelos estudantes nos grupos e fazer intervenções, caso entenda ser necessário; avaliar a aprendizagem dos alunos, com base em uma avaliação feita pelo próprio grupo sobre o seu desempenho (JOHNSON; JOHNSON; HOLUBEC, 1999).

Dentre as ações que o docente tem que efetuar antes da realização da atividade, cabe ressaltar a questão relativa à forma de distribuição dos alunos em seus respectivos grupos. Os grupos homogêneos são recomendados quando se busca promover o domínio de habilidades específicas ou o alcance de determinados objetivos educativos. Contudo, nos grupos heterogêneos, os alunos geralmente dão e recebem explicações com maior frequência e são levados a considerar uma perspectiva mais ampla, discutindo a questão da tarefa solicitada pelo professor, o que pode aprofundar a compreensão e acentuar a qualidade do raciocínio (JOHNSON; JOHNSON; HOLUBEC, 1999).

Além das atividades cooperativas formais, Johnson, Johnson e Holubec (1999) apresentam a possibilidade da realização de atividades cooperativas informais e em grupos de base.

Os grupos de aprendizagem cooperativa informal apresentam uma estrutura que permite aos estudantes se envolverem em discussões breves (três a cinco minutos), que podem ser realizadas antes do início de uma explicação ou após seu término, ou ainda ao longo de toda uma explicação. Quando aplicados em aulas baseadas em seminários ou em projeção de vídeos, por exemplo, podem fazer com que os alunos fiquem mais atentos à matéria abordada. 
Os grupos de base são formados por estudantes que realizam atividades regulares juntos e por um longo período (duração mínima de aproximadamente um semestre). Com característica heterogênea, são formados por integrantes com diferentes níveis de desempenho, motivação e disposição para realizar a atividade proposta. É importante que os participantes saibam que o grupo se manterá unido por um longo período, o que os estimulará a buscar formas de motivar e estimular os outros participantes do grupo. Nessa perspectiva, é essencial que os estudantes acompanhem e participem do progresso acadêmico de seus companheiros, ajudando-os a alcançar seus objetivos.

Diversas formas e métodos de aplicação, fundados nos conceitos da aprendizagem cooperativa, foram desenvolvidos e são objeto de amplos estudos (COCHITO, 2004), dentre os quais podemos destacar: a Instrução Complexa, o TGT (Teams-Games-Tournament), o STAD (Student Teams Achievement Division) e o jigsaw. Cada um desses métodos tem características particulares e a opção por um ou outro deve ser feita dependendo do objetivo do docente e da disciplina na qual o método vai ser aplicado. Essa escolha é parte essencial para que a aprendizagem cooperativa seja bem-sucedida. O método jigsaw, que baseou a elaboração de atividades didáticas descritas no presente trabalho, será discutido mais detidamente no capítulo Referenciais Teóricos.

É importante ressaltar que algumas teorias subjacentes à aprendizagem cooperativa são de grande importância para sua compreensão, de forma que consideramos relevante descrevê-las:

Teoria da interdependência social: suas bases teóricas estão ligadas a Kurt Kafka. Com trabalhos datados da década de 1920, definia os grupos como conjuntos dinâmicos em que a interdependência de seus integrantes era um fator variável. Suas ideias tiveram continuidade e se aperfeiçoaram na mão de pesquisadores como Kurt Lewis e Morton Deutsch, sendo ampliadas por pesquisadores como Johnson e Johnson e culminando na perspectiva que assume a forma de interdependência social como fator capaz de definir o tipo de interação entre os indivíduos, influenciando diretamente e até definindo os seus resultados. A interdependência positiva (cooperação) gera como resultado uma interação, na qual os estudantes facilitam, com seus esforços, a aprendizagem dos demais membros do grupo. Na interdependência negativa (competição), por sua vez, os estudantes não estão necessariamente interligados, podendo levar a resultados de oposição. 
Nessa hipótese, os estudantes dificultam o trabalho dos demais. Pode ainda acontecer de não haver interdependência (individualismo), situação em que os alunos não interagem e trabalham de forma independente (JOHNSON; JOHNSON; HOLUBEC, 1999).

Teoria do desenvolvimento cognitivo, fundada nas obras de Piaget, Vigotsky e de outros teóricos a eles relacionados: segundo Piaget, os ambientes cooperativos são capazes de gerar conflitos sócio-cognitivos, que causam desequilíbrios cognitivos, os quais, por sua vez, podem levar ao desenvolvimento cognitivo. De forma similar, Vygotsky parte do pressuposto de que o conhecimento é uma ação social que advém do esforço para aprender, compreender e resolver problemas (JOHNSON; JOHNSON; HOLUBEC, 1999).

Teoria da aprendizagem comportamental: centrada no impacto que o reforço positivo e a recompensa exercem na aprendizagem dos estudantes. Tem como base os trabalhos de pesquisadores como Skinner, Bandura e Homans, Thibaus e Kelley. Mais recentemente, é apresentada nos trabalhos de Slavin, que chama a atenção para a necessidade das recompensas grupais com o intuito de motivar os estudantes a aprender (JOHNSON; JOHNSON; HOLUBEC, 1999).

\subsection{Aprendizagem Colaborativa}

O termo aprendizagem colaborativa tem sido empregado para caracterizar uma metodologia para o processo de ensino-aprendizagem envolvendo o trabalho em grupos, com o objetivo de socializar e construir conhecimentos, mediados por um indivíduo mais experiente, neste caso o docente.

Para Dillenbourg (1999), conceituar a aprendizagem colaborativa não é simples porque há uma diversidade de usos desse termo tanto no campo acadêmico quanto em outros campos. São duas as grandes preocupações de Dillenbourg (1999) acerca desse conceito: a primeira é a excessiva generalização com a qual a “colaboração" vem sendo utilizada - não há uma preocupação em definir com clareza quais são as condições mínimas para que uma situação de aprendizagem seja caracterizada como colaborativa; a segunda, a articulação das contribuições dos diversos autores, pois expressam ideias muito divergentes sobre o termo. 
Conforme Dillenbourg (1999), mesmo que de uma forma ainda insatisfatória, a aprendizagem colaborativa pode ser definida como "uma situação em que duas ou mais pessoas aprendem ou tentam aprender algo juntas" (p.1). O autor complementa afirmando que cada um dos elementos da definição pode ser interpretado de formas diferenciadas. No entanto, permanece o fundamento: aprendizagem colaborativa implica interação entre grupos de pessoas, presencialmente ou não, com o intuito de aprender algo juntas.

Dillenbourg (1999) menciona ainda a diferença entre a cooperação e a colaboração, que pode ser traduzida pelo modo como é organizada a tarefa pelo grupo. Na colaboração, todos trabalham em conjunto, em um esforço coordenado, a fim de alcançar o objetivo ao qual se propuseram. Já na cooperação, a estrutura hierárquica prevalece e cada um dos membros da equipe é responsável por uma parte da tarefa.

O Quadro 1 apresenta algumas diferenças e semelhanças entre as aprendizagens colaborativa e cooperativa, segundo Figueiredo (2006).

Quadro 1 - Diferenças e semelhanças entre as aprendizagens colaborativa e cooperativa.

\begin{tabular}{|c|c|}
\hline Aprendizagem colaborativa & Aprendizagem cooperativa \\
\hline O foco é no processo. & O foco é no produto. \\
\hline $\begin{array}{c}\text { Diferenças atividades dos membros do grupo são } \\
\text { geralmente não-estruturadas: os seus papéis } \\
\text { são definidos à medida que a atividade se } \\
\text { desenvolve. }\end{array}$ & $\begin{array}{c}\text { As atividades dos membros do grupo são } \\
\text { geralmente estruturadas: os seus papéis são } \\
\text { definidos a priori, sendo resguardada a } \\
\text { possibilidade de renegociação desses papéis. }\end{array}$ \\
\hline $\begin{array}{c}\text { Com relação ao gerenciamento das } \\
\text { atividades, a abordagem é centrada no aluno. }\end{array}$ & $\begin{array}{c}\text { Com relação ao gerenciamento das atividades, a } \\
\text { abordagem é centrada no professor. }\end{array}$ \\
\hline $\begin{array}{c}\text { O professor não dá instruçães aos alunos } \\
\text { sobre como realizar as atividades em grupo. }\end{array}$ & $\begin{array}{c}\text { O professor dá instruções aos alunos sobre como } \\
\text { realizar as atividades em grupo. }\end{array}$ \\
\hline Semelhanças \\
\hline Os alunos tornam-se mais ativos no processo de ensino-aprendizagem, já que não recebem \\
passivamente informações do professor.
\end{tabular}

Tomando como base o Quadro 1, na aprendizagem cooperativa os indivíduos são responsáveis pelo grupo e vice-versa; o professor facilita, mas o grupo é primordial. Nesse modelo, mesmo que os estudantes trabalhem em grupo para realizar os objetivos de uma atividade, o professor mantém o domínio de cada estágio da atividade. Na aprendizagem colaborativa os alunos são os sujeitos que estruturam o processo para o desenvolvimento das atividades. Eles engajam-se em 
atividades com outros companheiros mais capazes, os quais dão assistência e os guiam em busca de novas fontes, promovendo a aculturação dos alunos nas comunidades de conhecimento. Nesse caso, o professor avalia a evolução do grupo e fornece sugestões sobre a fase de desenvolvimento de suas atividades.

A aprendizagem colaborativa parte da ideia de construção coletiva, na busca de novos conhecimentos, que por sua vez, resultam da interação entre os indivíduos. São várias as teorias que contribuem para a compreensão da aprendizagem colaborativa, embora todas tenham em comum o mesmo objetivo: considerar os indivíduos como agentes ativos na construção de seu conhecimento. Nessa perspectiva, a Teoria do desenvolvimento cognitivo, mencionada anteriormente, e baseada nas obras de Piaget e Vigotsky, é a que mais dá suporte aos ambientes de aprendizagem colaborativa.

O método PLTL (Peer-Led Team Learning), que fundamentou a elaboração de atividades didáticas descritas neste trabalho, será discutido detalhadamente no capítulo Referenciais Teóricos.

\subsection{Aprendizagem Cooperativa e Colaborativa no Ensino de Ciências: Panorama das Pesquisas Nacionais e Internacionais}

Com o objetivo de situarmos o nosso trabalho na área de Pesquisa em Ensino de Ciências, buscamos investigações sobre aprendizagem cooperativa e colaborativa nas revistas que constam na área de avaliação do Programa QUALIS da Coordenação de Aperfeiçoamento de Pessoal de Nível Superior (CAPES). O Programa QUALIS consiste em um conjunto de procedimentos utilizados pela CAPES para estratificação da qualidade da produção intelectual dos programas de pós-graduação. A estratificação da qualidade é realizada de uma maneira indireta. Dessa forma, o QUALIS afere a qualidade dos artigos e de outros tipos de produção, a partir da análise da qualidade dos veículos de divulgação, ou seja, periódicos científicos. Os periódicos são separados pelas áreas de avaliação, sendo atualizados anualmente. Esses veículos são enquadrados em estratos que indicam sua qualidade: A1; A2; B1; B2; B3; B4; B5 e C. Consultamos os periódicos QUALIS A1, A2, B1 e B2 da área 38 (Educação), que se relacionavam ao Ensino de 
Ciências, assim como os da área 46 (Ensino). No Apêndice A, encontram-se elencadas as revistas pesquisadas (CAPES 2014).

Também foram analisados os trabalhos apresentados nas edições até 2013 do Encontro Nacional de Pesquisa em Educação em Ciências (ENPEC), encontro mais representativo da área de Ensino de Ciências no Brasil, assim como, as revistas Química Nova e Química Nova na Escola, vinculadas à Sociedade Brasileira de Química, referências nacionais na área de Educação em Química e de ampla penetração na comunidade científica.

A sistemática de busca e seleção dos periódicos deu-se em três etapas: primeiramente, pela verificação de menções à aprendizagem cooperativa, cooperative learning, co-operative learning, aprendizagem colaborativa, colaborative learning, aprendizaje colaborativo, cooperativo, cooperative, cooperación, colaborativo, collaborative, cooperando, cooperating, colaboração, collaboration, Peer-Led Team Learning, PLTL, jigsaw, grupo, group, small-group, workshop, peerled, team, interação, interaction, coletivo, nos títulos dos trabalhos; na segunda etapa, os trabalhos pré-selecionados tiveram seus resumos lidos e, deste conjunto, selecionamos os que faziam referência a pesquisas ou a relatos de atividades planejadas com base nos preceitos da aprendizagem cooperativa ou colaborativa; na terceira etapa, os trabalhos selecionados foram lidos na íntegra.

Em seguida, os trabalhos foram analisados com relação à produção, de acordo com a distribuição no tempo, com a área de pesquisa, com os níveis de escolaridade e com o foco temático privilegiado nos estudos.

\subsubsection{Aprendizagem Cooperativa e Colaborativa: Âmbito Internacional}

$\mathrm{Na}$ Tabela 1 é apresentado um total de treze revistas internacionais nas quais encontramos trabalhos sobre a temática. Nela constam o período em que o levantamento foi realizado, bem como a quantidade de trabalhos localizados por revista. Ressaltamos que o período de pesquisa foi variável, seguindo a disponibilidade das revistas. 
Tabela 1 - Revistas internacionais analisadas, períodos em que o levantamento foi realizado e a quantidade de trabalhos localizados em cada uma delas.

\begin{tabular}{lcc}
\hline Periódicos & Período & $\mathbf{N}^{\circ}$ de trabalhos \\
\hline Cell Biology Education & 2002 a 2013 & 7 \\
International Journal of Science Education & 1979 a 2010 & 24 \\
American Journal of Physics & 1970 a 2010 & 6 \\
Enseñanza de las Ciencias & 1983 a 2013 & 4 \\
Biochemistry and Molecular Biology Education & 1972 a 2013 & 3 \\
Revista Electrónica de Enseñanza de las Ciencias & 2003 a 2013 & 6 \\
Physics Education & 1970 a 2010 & 1 \\
Research in Science \& Technological Education & 1983 a 2013 & 2 \\
Revista Eureka sobre Enseñanza y Divulgación de & 2004 a 2013 & 2 \\
las Ciencias & & \\
Latin American Journal of Physics Education & 2007 a 2013 & 4 \\
Science \& Education & 1992 a 2013 & 1 \\
Cultural Studies of Science Education & 2006 a 2013 & 2 \\
Revista de la Facultad de Ciencia y Tecnologia & 1998 a 2013 & 1 \\
Total & & 63 \\
\hline
\end{tabular}

$\mathrm{Na}$ Tabela 2 listamos os trabalhos encontrados sobre o tema nas revistas referidas anteriormente, em ordem cronológica de publicação. Os artigos relativos à aprendizagem cooperativa encontram-se sombreados, de forma distinta dos relativos à aprendizagem colaborativa.

Tabela 2 - Artigos sobre aprendizagem cooperativa sombreados e artigos sobre aprendizagem colaborativa não sombreados, localizados nas revistas internacionais analisadas e seu respectivo ano de publicação.

(continua)

\begin{tabular}{|c|c|c|}
\hline $\mathrm{N}^{\circ}$ & Autor e Título & $\begin{array}{c}\text { Ano de } \\
\text { Publicação }\end{array}$ \\
\hline \multicolumn{3}{|c|}{ Cell Biology Education } \\
\hline 1 & $\begin{array}{l}\text { TANNER, K.; CHATMAN, L. S.; ALLEN, D. Approaches to cell } \\
\text { biology teaching: cooperative learning in the science classroom } \\
\text { - beyond students working in groups }\end{array}$ & 2003 \\
\hline 2 & $\begin{array}{l}\text { ARMSTRONG, N.; CHANG, S.; BRICKMAN, M. Cooperative } \\
\text { learning in industrial-sized biology classes }\end{array}$ & 2007 \\
\hline 3 & $\begin{array}{l}\text { SEIFERT, K.; FENSTER, A.; DILTS, J. A.; TEMPLE, L. An } \\
\text { investigative, cooperative learning approach to the general } \\
\text { microbiology laboratory }\end{array}$ & 2009 \\
\hline 4 & $\begin{array}{l}\text { PRESZLER, R. W. Replacing lecture with peer-led workshops } \\
\text { improves student learning }\end{array}$ & 2009 \\
\hline 5 & $\begin{array}{l}\text { STANGER-HALL, K. F.; LANG, S.; MASS, M. Facilitating } \\
\text { learning in large lecture classes: testing the "teaching team" } \\
\text { approach to peer learning }\end{array}$ & 2010 \\
\hline
\end{tabular}
composition and inquiry instruction on reasoning gains and achievement in undergraduate biology 
Tabela 2 - Artigos sobre aprendizagem cooperativa sombreados e artigos sobre aprendizagem colaborativa não sombreados, localizados nas revistas internacionais analisadas e seu respectivo ano de publicação.

\begin{tabular}{|c|c|c|}
\hline $\mathrm{N}^{\circ}$ & Autor e Título & $\begin{array}{c}\text { (continuação) } \\
\text { Ano de } \\
\text { Publicação }\end{array}$ \\
\hline 7 & $\begin{array}{l}\text { LEIGHT, H.; SAUNDERS, C.; CALKINS, K.; WITNERS, M. } \\
\text { Collaborative testing improves performance but not content } \\
\text { retention in a large-enrollment introductory biology class }\end{array}$ & 2012 \\
\hline \multicolumn{3}{|c|}{ International Journal of Science Education } \\
\hline 8 & $\begin{array}{l}\text { OKEBUKOLA, P. A. The problem of large classes in science: an } \\
\text { experiment in co-operative learning }\end{array}$ & 1986 \\
\hline 9 & $\begin{array}{l}\text { KEMPA, R. F.; AYOB, A. Learning interactions in group work in } \\
\text { science }\end{array}$ & 1991 \\
\hline 10 & $\begin{array}{l}\text { GAYFORD, C. Patterns of group behaviour in open-ended } \\
\text { problem solving in science classes of } 15 \text {-year-old students in } \\
\text { England }\end{array}$ & 1992 \\
\hline 11 & $\begin{array}{l}\text { CONWELL, C. R.; GRIFFIN, S.; ALGOZZINE, B. Gender and } \\
\text { racial differences in unstructured learning groups in science }\end{array}$ & 1993 \\
\hline 12 & KEMPA, R. F.; AYOB, A. Learning from group work in science & 1995 \\
\hline
\end{tabular}

13 THIJS, G. D.; BOSCH, G. M. Cognitive effects of science 1995 experiments focusing on students' preconceptions of force: a comparison of demonstrations and small-group practicals

14 LAZAROWITZ, R.; BAIRD, J. H.; BOWLDEN, V.; HERTZ- 1996 LAZAROWITZ, R. Teaching biology in a group mastery learning mode: high school students' academic achievement and affective outcomes

15 ALEXOPOULOU, E.; DRIVER, R. Gender differences in small 1997 group discussion in physics

16 BANERJEE, A. C.; VIDYAPATI, T. J. Effect of lecture 1997 and cooperative learning strategies on achievement in chemistry in undergraduate classes

17 SHE, H. Students' knowledge construction in small groups in 1999 the seventh grade biology laboratory: verbal communication and physical engagement

18 HOGAN, K. Sociocognitive roles in science group discourse 1999

19 BARBOSA, R.; JÓFILI, Z.; WATTS, M. Cooperating in 2004 constructing knowledge: case studies from chemistry and citizenship

20 TAO, P. Developing understanding of image formation by 2004 lenses through collaborative learning mediated by multimedia computer-assisted learning programs

21 OSHIMA, J.; OSHIMA, R.; MURAYAMA, I.; INAGAKI, S.; 2004 TAKENAKA, M.; NAKAYAMA, H.; YAMAGUCHI, E. Design experiments in Japanese elementary science education with computer support for collaborative learning: hypothesis testing and collaborative construction 
Tabela 2 - Artigos sobre aprendizagem cooperativa sombreados e artigos sobre aprendizagem colaborativa não sombreados, localizados nas revistas internacionais analisadas e seu respectivo ano de publicação.

\begin{tabular}{llc}
\hline$N^{\circ}$ & Autor e Título & $\begin{array}{c}\text { (continuação) } \\
\text { Ano de } \\
\text { Publicação }\end{array}$ \\
\hline 22 & $\begin{array}{l}\text { HARSKAMP, E.; DING, N. Structured collaboration versus } \\
\text { individual learning in solving physics problems }\end{array}$ & 2006 \\
\hline 23 & $\begin{array}{l}\text { MALONEY, J.; SIMON, S. Mapping children's discussions of } \\
\text { evidence in science to assess collaboration and argumentation }\end{array}$ & 2006 \\
\hline 24 & $\begin{array}{l}\text { BERGER, R.; HANZE, M. Comparison of two small-group } \\
\text { learning methods in 12th-grade physics classes focusing on } \\
\text { intrinsic motivation and academic performance }\end{array}$ & 2009 \\
\hline 25 & $\begin{array}{l}\text { THURSTON, A.; TOPPING, K. J.; TOLMIE, A.; CHRISTIE, D.; } \\
\text { KARAGIANNIDOU, E. ; MURRAY, P. Cooperative learning in } \\
\text { science: follow-up from primary to high school }\end{array}$ & \\
\hline 26 & $\begin{array}{l}\text { BELL, T.; URHAHNE, D.; SCHANZE, S.; PLOETZNER, R. } \\
\text { Collaborative inquiry learning: models, tools, and challenges }\end{array}$ & 2010 \\
\hline 27 & $\begin{array}{l}\text { HONG, Z. Effects of a collaborative science intervention on high } \\
\text { achieving students' learning anxiety and attitudes toward } \\
\text { science }\end{array}$ & 2010 \\
\hline
\end{tabular}

28 SANDI-URENA, S.; COOPER, M. M.; STEVENS, R. H. 2011 Enhancement of metacognition use and awareness by means of a collaborative intervention

29 DING, N.; HARSKAMP, E. G. Collaboration and peer tutoring in 2011 chemistry laboratory education

\begin{tabular}{|c|c|c|c|}
\hline 30 & $\begin{array}{l}\text { BERLAN, L. K.; LEE, V. R. In } \\
\text { disagreement } \\
\text { argumentation }\end{array}$ & $\begin{array}{c}\text { pursuit of consensus: } \\
\text { during small-group }\end{array}$ & 2012 \\
\hline 31 & $\begin{array}{l}\text { KIM, M.; TAN, H. T. A collaborative } \\
\text { through environmental field studies }\end{array}$ & & 2013 \\
\hline
\end{tabular}

\begin{tabular}{|c|c|c|}
\hline \multicolumn{3}{|c|}{ American Journal of Physics } \\
\hline 32 & EMKEY, W. L. Small group approach to introductory physics & 1979 \\
\hline 33 & $\begin{array}{l}\text { HELLER, P.; KEITH, R.; ANDERSON, S. Teaching problem } \\
\text { solving through cooperative grouping. Part 1: group versus } \\
\text { individual problem solving }\end{array}$ & 1992 \\
\hline 34 & $\begin{array}{l}\text { HELLER, P.; HOLLABAUGH, M. Teaching problem solving } \\
\text { through cooperative grouping. Part 2: designing problems and } \\
\text { structuring groups }\end{array}$ & 1992 \\
\hline 35 & $\begin{array}{l}\text { SAMIULLAH, M. Effect of in-class student-student interaction on } \\
\text { the learning of physics in a college physics course }\end{array}$ & 1995 \\
\hline 36 & $\begin{array}{l}\text { KALMAN, C. S.; MORRIS, S.; COTTIN, C.; GORDON, R. } \\
\text { Promoting conceptual change using collaborative groups in } \\
\text { quantitative gateway courses }\end{array}$ & 1999 \\
\hline 37 & $\begin{array}{l}\text { POTTER, W.; WEBB, D.; WEST, E.; PAUL, C.; BOWER, M.; } \\
\text { WEISS, B.; COLEMAN, L.; LEONE, C. Sixteen years of } \\
\text { collaborative learning through active sense-making in physics } \\
\text { (CLASP) at UC DAVIS }\end{array}$ & 2013 \\
\hline
\end{tabular}


Tabela 2 - Artigos sobre aprendizagem cooperativa sombreados e artigos sobre aprendizagem colaborativa não sombreados, localizados nas revistas internacionais analisadas e seu respectivo ano de publicação.

(continuação)

$\mathrm{N}^{\circ} \quad$ Autor e Título Ano de

Publicação

\section{Enseñanza de las Ciencias}

38 CORDERO, S.; COLINVAUX, D.; DUMRAUF, A. G. ¿Y si 2002 trabajan en grupo...? interacciones entre alumnos, procesos sociales y cognitivos en clases universitarias de física

39 FURIÓ, C.; CARNICER, J. El desarrollo profesional del profesor de ciencias mediante tutorías de grupos cooperativos. Estudio de ocho casos

40 VALVERDE, G. J.; VIZA, A. L. Optimización metodológica de 2008 entornos telemáticos cooperativos (bscw y sinergeia) como recursos didácticos de la química en la producción de hipermedia

41 DURÁN-GARCÍA, M. $\quad$ E.; DURÁN-APONTE, E. E. La 2013 termodinámica en los estudiantes de tecnología: una experiencia de aprendizaje cooperativo

\section{Biochemistry and Molecular Biology Education}

42 ANDERSON, W. L.; MITCHELL, S. M.; OSGOOD, M. P. 2005 Comparison of student performance in cooperative learning and traditional lecture-based biochemistry classes

43 FERNÁNDEZ-SANTANDER, A. Cooperative learning combined 2008 with short periods of lecturing

44 TAYLOR, A. Top 10 reasons students dislike working in small 2011 groups... and why I do it anyway

\section{Revista Electrónica de Enseñanza de las Ciencias}

45 GARCÍA, A. G.; TUÑÓN, M. J. I. El ciclo reflexivo cooperativo: 2004 un modelo didáctico para la enseñanza de las ciencias

46 VALVERDE, G. J.; JIMÉNEZ, R. L.; VIZA, A. L. Los niveles de 2005 abertura en las prácticas cooperativas de química

47 COSTA, A. R.; OLIVEIRA, J. P.; ALVES, J. M. Analisando a 2008 construção de explicações individuais e coletivas em aulas sobre ligações iônicas, na 8a série

48 GIANOTTO, D. E. P.; DINIZ, R. E. S. Formação inicial de 2009 professores de biologia: a prática colaborativa e o uso pedagógico do computador

49 REZENDE, F; CASTELLS, M. Interanimation of voices and 2010 argumentative strategies in collaborative knowledge building of physics teachers in an asynchronous discussion group

50 RAMOS, C. R.; SILVA, H. S.; LOPES, J. A aprendizagem no 2013 ensino-aprendizagem das ciências naturais através de um método de aprendizagem cooperativa

\section{Physics Education}

51 MILLS, D.; MCKITTRICK, B. MULHALL, P.; FETERIS, S. CUP: 1999 Cooperative learning that works 
Tabela 2 - Artigos sobre aprendizagem cooperativa sombreados e artigos sobre aprendizagem colaborativa não sombreados, localizados nas revistas internacionais analisadas e seu respectivo ano de publicação.

\begin{tabular}{|c|c|c|}
\hline $\mathrm{N}^{\circ}$ & Autor e Título & $\begin{array}{c}\text { Ano de } \\
\text { Publicação }\end{array}$ \\
\hline \multicolumn{3}{|c|}{ Research in Science \& Technological Education } \\
\hline 52 & $\begin{array}{l}\text { DOYMUS, K. Teaching chemical bonding } \\
\text { jigsaw cooperative learning }\end{array}$ & 2008 \\
\hline 53 & $\begin{array}{l}\text { TARHAN, L.; AYYILDIZ, Y.; OGUNC, A.; ACAR, B. S. A jigsaw } \\
\text { cooperative learning application in elementary science and } \\
\text { technology lessons: physical and chemical changes }\end{array}$ & 2013 \\
\hline \multicolumn{3}{|c|}{ Revista Eureka sobre Enseñanza y Divulgación de las Ciencias } \\
\hline 54 & $\begin{array}{l}\text { VALVERDE, G. J.; VIZA, A. L. Deducción de calificaciones } \\
\text { individuales en actividades cooperativas: una oportunidad para } \\
\text { la coevaluación y la autoevaluación en la enseñanza de las } \\
\text { ciencias }\end{array}$ & 2006 \\
\hline 55 & $\begin{array}{l}\text { VALVERDE, G. J.; VIZA, A. L. Cooperación en entornos } \\
\text { telemáticos y la enseñanza de la química }\end{array}$ & 2006 \\
\hline \multicolumn{3}{|c|}{ Latin American Journal of Physics Education } \\
\hline 56 & $\begin{array}{l}\text { TANEL, Z.; EROL, M. Effects of cooperative learning on } \\
\text { instructing magnetism: analysis of an experimental teaching } \\
\text { sequence }\end{array}$ & 2008 \\
\hline 57 & $\begin{array}{l}\text { CASTELLVI, F. Descripción de un proyecto de aprendizaje } \\
\text { cooperativo multidisciplinar. Estimación versus medida de la } \\
\text { radiación neta }\end{array}$ & 2010 \\
\hline 58 & $\begin{array}{l}\text { DURÁN, S. R.; SÁNCHEZ-GUZMÁN, D. El cálculo de la fuerza } \\
\text { resultante de un par de fuerzas sobre un punto fijo por los } \\
\text { estudiantes de secundaria mediante técnicas colaborativas }\end{array}$ & 2010 \\
\hline 59 & $\begin{array}{l}\text { KEBAN, F.; EROL, M. Effects of strategy instruction in } \\
\text { cooperative learning groups concerning undergraduate physics } \\
\text { labworks }\end{array}$ & 2011 \\
\hline \multicolumn{3}{|c|}{ Cultural Studies of Science Education } \\
\hline 60 & $\begin{array}{l}\text { VENVILLE, G. Powerful knowledge and quality talk: maximising } \\
\text { learning of genetics during collaborative group work }\end{array}$ & 2009 \\
\hline 61 & $\begin{array}{l}\text { FURBERG, A.; ARNSETH, H. C. Reconsidering conceptual } \\
\text { change from a socio-cultural perspective: analyzing students' } \\
\text { meaning making in genetics in collaborative learning activities }\end{array}$ & 2009 \\
\hline \multicolumn{3}{|c|}{ Revista de la Facultad de Ciencia y Tecnologia } \\
\hline 62 & $\begin{array}{l}\text { RAMÍREZ, O. H. F. Hipertextos y mapas conceptuales em } \\
\text { ambientes de aprendizaje colaborativo }\end{array}$ & 2000 \\
\hline \multicolumn{3}{|c|}{ Science \& Education } \\
\hline 63 & $\begin{array}{l}\text { HANSSON, L.; REDFORS, A. Upper secondary students in } \\
\text { group discussions about physics and our presuppositions of the } \\
\text { world }\end{array}$ & 2007 \\
\hline
\end{tabular}




\subsubsection{A produção e sua distribuição no tempo}

Com base nos dados encontrados no levantamento bibliográfico realizado, constatamos que o número de trabalhos publicados com questões referentes ao tema em foco aumentou significativamente a partir da década de 1990 e, considerando os trabalhos publicados de 2010 a 2013, essa tendência de crescimento manter-se-á.

Figura 1 - Quantidade de trabalhos sobre aprendizagem cooperativa (APCP) e aprendizagem colaborativa (APCL) localizados no âmbito internacional.

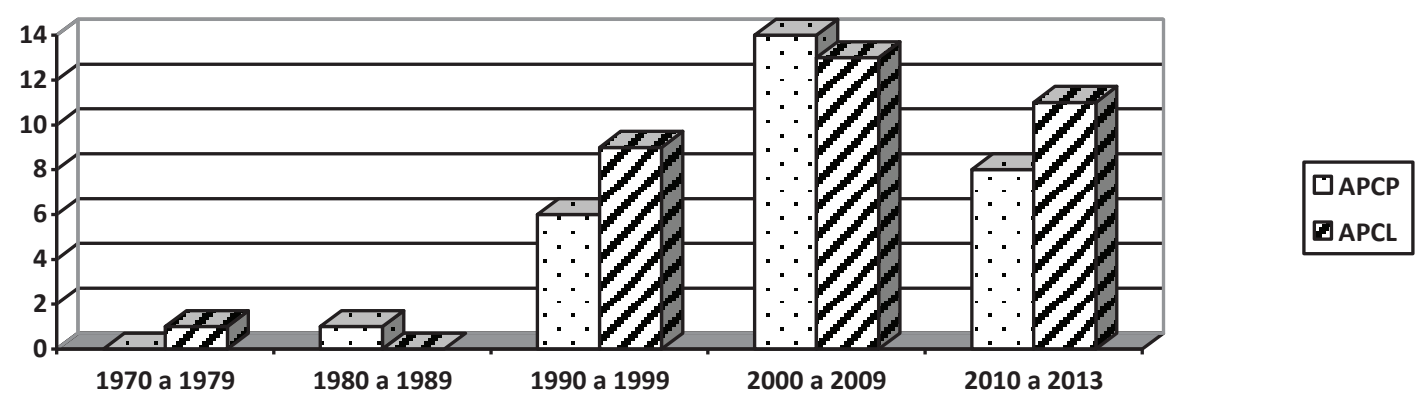

Podemos inferir, com base na Figura 1, o crescente interesse nos temas pesquisados. Houve apenas uma publicação na década de 1970 sobre aprendizagem colaborativa, no periódico American Journal of Physics, e uma na década de 1980 sobre aprendizagem cooperativa, no periódico International Journal of Science Education. O pequeno número de publicações nas décadas de 1960 a 1980 deve-se ao fato de o foco dos pesquisadores nesse período ser direcionado, principalmente, para a compreensão da relação entre comportamento dos professores e o rendimento acadêmico dos alunos, forma de investigação denominada de aproximação processo-produto. Nesse período, a investigação sobre a temática em questão ainda era escassa, sendo representada por poucos grupos de pesquisas que, na década de 1970, começaram a desenvolver estudos de comparação entre diferentes formas de organização social nas salas de aula e constataram que a organização colaborativa era mais eficiente que a competitiva e a individualista (COSTA; OLIVEIRA; ALVES, 2008).

Já na década de 1990, o foco dos pesquisadores mudou, sendo direcionado para a análise dos processos interativos e de como a interação pode ser usada em sala de aula, o que levou ao aumento na produção de artigos sobre a temática em 
questão. Encontramos seis publicações sobre a aprendizagem cooperativa e nove sobre aprendizagem colaborativa na década de 1990 e, como resultado, percebeuse que a eficácia das organizações colaborativas era variável, sendo que os pesquisadores começaram a investigar os fatores determinantes para essa variação, o que justifica o aumento no número de artigos publicados nos anos seguintes (COSTA; OLIVEIRA; ALVES, 2008).

No período de 2000 a 2009, foram publicados quatorze artigos sobre aprendizagem cooperativa e treze artigos sobre aprendizagem colaborativa e nos quatro primeiros anos da década atual já foram publicados oito e onze artigos, respectivamente.

Além do aumento na quantidade, as publicações ocorrem em revistas de Educação em Biologia, Física, Química e Ciências, revelando que a aprendizagem cooperativa e a colaborativa se adéquam a diversas áreas de ensino (TANNER; CHATMAN; ALLEN, 2003; VALVERDE; VIZA, 2006; ARMSTRONG; CHANG; BRICKMAN, 2007; JENSEN; LAWSON, 2011).

Os artigos publicados no ano de 2014 e 2015 não foram considerados, tendo em vista que o levantamento bibliográfico foi realizado no decorrer de 2014, quando alguns periódicos ainda não haviam publicado todos seus volumes nesse ano. Assim, eventual análise sobre os dados referentes a esse ano resultaria incompleta.

\subsubsection{A produção e sua distribuição de acordo com os níveis de escolaridade}

Foram considerados os níveis Fundamental, Médio, Superior e Geral na classificação dos trabalhos quanto ao nível de escolaridade. Para identificar o nível escolar ao qual se relacionam os trabalhos, levamos em consideração os sujeitos participantes da pesquisa, os materiais didáticos utilizados na pesquisa, as experiências educacionais descritas na pesquisa e os programas de ensino propostos, fatores sugeridos por Megid Neto (1999). Foram classificados na categoria geral os trabalhos que abordam os níveis escolares de forma genérica, sem nenhuma especificação ou abordagem preferencial para qualquer etapa de escolarização. 
Figura 2 - Distribuição dos trabalhos sobre aprendizagem cooperativa (APCP) e aprendizagem colaborativa (APCL) de acordo com os níveis de escolaridade.

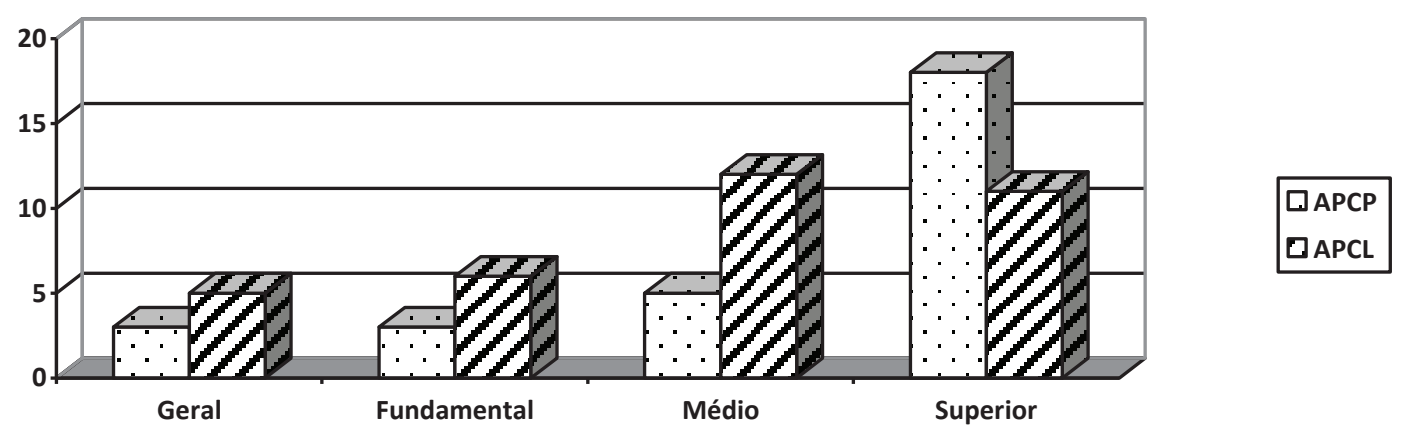

Conforme ilustra a Figura 2, o Ensino Superior é o nível de escolaridade em que mais experiências com aprendizagem cooperativa e colaborativa foram reportadas: dos 63 trabalhos, 29 relacionam-se ao Ensino Superior, representando $46 \%$ do total. O elevado número de trabalhos encontrados pode ser justificado pelo fato de as atividades em grupo se mostrarem como uma alternativa na busca por uma educação que aproxime a sala de aula da realidade de trabalho em laboratórios de Ciências, considerando que no mundo profissional as atividades são realizadas de forma colaborativa e não individual (TANNER; CHATMAN; ALLEN, 2003).

As atividades em grupo permitem a aproximação da sala de aula com o que ocorre no dia a dia da investigação científica, que tem na colaboração entre os pares uma de suas características fundamentais (TANNER; CHATMAN; ALLEN, 2003). Simultaneamente, a aprendizagem cooperativa e a colaborativa possibilitam um ambiente propício para o desenvolvimento de habilidades interpessoais necessárias ao trabalho em laboratório, onde as atividades são realizadas em grupo (VALVERDE; JIMÉNEZ; VIZA; 2005). Assim, estas, em geral, são aplicadas nesse nível de ensino com o objetivo de desenvolver tais habilidades interpessoais $\mathrm{e}$ colaborativas (ARMSTRONG; CHANG; BRICKMAN, 2007). Ademais, as práticas cooperativas e colaborativas são vistas por muitos pesquisadores como alternativas às aulas estritamente expositivas, usuais em muitas universidades (FERNÁNDEZSANTANDER, 2008; SEIFERT et al., 2009).

Os níveis de escolaridade Fundamental e Médio foram representados por oito trabalhos direcionados à aprendizagem cooperativa e dezoito direcionados à aprendizagem colaborativa. A quantidade inferior de trabalhos encontrados sobre aprendizagem cooperativa justifica-se pelas dificuldades apontadas em algumas pesquisas que relatam uma resistência por parte dos docentes e dos alunos, que se 
sentem desconfortáveis frente a atividades não tradicionais (GARCÍA; TUÑÓN, 2004, ANDERSON; MITCHELL; OSGOOD, 2005). Essas dificuldades não são relatadas de forma tão incisiva no Ensino Superior, possivelmente pelo preparo dos docentes e pela maturidade dos alunos nesse nível.

Ressalte-se que, devido à sua estrutura, o uso da atividade cooperativa não implica simplesmente em organizar os alunos em grupos, mas exige uma preparação do docente, como apontado por Johnson, Johnson e Holubec (1999, p. 25), da seguinte forma:

Muitas vezes, os docentes que utilizam aprendizagem cooperativa nos dizem 'Porém não digam que é fácil'. Sabemos que não é, pode-se levar anos para se tornar um especialista, existe muita pressão para que ensinemos como os demais, entretanto, é necessário vencer tais barreiras e explorar mais a abordagem cooperativa nestes níveis de ensino.

Dessa maneira, o uso da aprendizagem cooperativa na sua plenitude pode parecer distante da realidade, entretanto é importante destacar que a introdução das estratégias cooperativas e de seus conceitos pode e deve ocorrer de forma gradativa indo de atividades semiestruradas e parciais a atividades estruturadas e completas (TANNER; CHATMAN; ALLEN, 2003).

$\mathrm{Na}$ categoria Geral foram classificados oito trabalhos: três sobre aprendizagem cooperativa e cinco sobre aprendizagem colaborativa. Dois dos artigos apresentaram análises teóricas sobre os elementos que compõem a aprendizagem cooperativa e a aprendizagem colaborativa. No primeiro é relatada a importância do papel do professor no desenvolvimento da atividade, sendo ele responsável por torná-la possível, apesar das dificuldades. Os autores também afirmam que a aprendizagem cooperativa não pode ser encarada como uma simples atividade em grupo, pois se assim for feito, um erro será cometido, já que a aprendizagem cooperativa envolve uma estrutura predeterminada e se pauta em resultados de pesquisas que remontam a muitas décadas, nas quais foram buscados estratégias e materiais capazes de tornar a aprendizagem em grupo algo mais estruturado e mais efetivo (VENVILLE, 2009). No segundo trabalho, pautado na aprendizagem colaborativa, a preocupação com a estrutura não é relatada, nele a atenção é direcionada para adequação da disciplina à estratégia, assim como a postura do professor e dos alunos frente à estratégia (TANNER; CHATMAN; ALLEN, 2003). 
Ainda na categoria Geral, encontramos três trabalhos voltados à análise de programas de computador, desenvolvidos e utilizados em parceria com atividades em grupos. O primeiro descreve um ambiente online cooperativo, que permite que os alunos realizem atividades usando o meio virtual, experiência esta que amplia as possibilidades do uso da aprendizagem cooperativa, tornando os alunos capazes de superar as limitações de espaço e tempo (VALVERDE; VIZA, 2008). O segundo descreve ambientes de colaboração assistidos por computadores, analisa suas ferramentas e os desafios do seu uso (BELL et al., 2010). Já o terceiro faz uso de um fórum de discussão com o objetivo de permitir que os docentes e os futuros docentes adquiram um meio capaz de desenvolver suas habilidades colaborativas e argumentativas (REZENDE; CASTELLS, 2010).

Três dos artigos encontrados envolviam pesquisadores que trabalharam simultaneamente com alunos de séries diferentes, um em estratégia cooperativa e dois em atividades colaborativas (BARBOSA; JÓFILI; WATTS, 2004; SANDIURENA; COOPER; STEVENS, 2011; KIM; TAN, 2013). Por último, citamos o trabalho que tratou da formação continuada de professores e de como uma atividade colaborativa pode favorecer o processo de aprendizagem de Ciências (FURIÓ; CARNICER, 2002).

\subsubsection{A produção e sua distribuição de acordo com a área investigada}

No que diz respeito à área investigada, conforme ilustra a Figura 3, de todos os trabalhos encontrados, quatorze são concernentes à área de Química, quinze à área de Ciências, treze à área de Biologia e 21 à área de Física. Cabe lembrar que a área de Ciências engloba os trabalhos direcionados para o ensino de Ciências nas series finais do Ensino Fundamental e aqueles que, mesmo sem direcionamento, discutem temas normalmente voltados para esta área de investigação. 
Figura 3 - Classificação dos trabalhos de acordo com a área investigada.

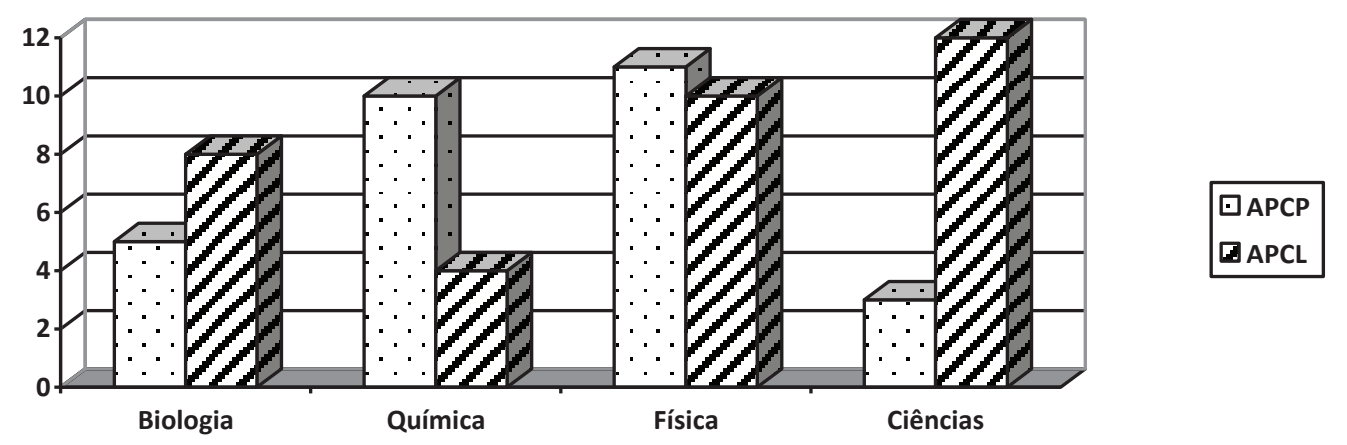

Os dados relativos à área de ensino investigada indicam uma variação na quantidade de trabalhos publicados para cada tipo de estratégia mas, de uma forma geral, temos a execução das duas estratégias nas diversas áreas. Esses resultados estão de acordo com dados reportados na literatura, os quais indicam que ambas as estratégias podem ser adaptadas para qualquer área de ensino (TANNER; CHATMAN; ALLEN, 2003; VALVERDE; VIZA, 2006; ARMSTRONG; CHANG; BRICKMAN, 2007; THURSON et al., 2010). Todavia, percebe-se uma inversão na forma como as estratégias são usadas nas áreas de Ciências e Química, na primeira a estratégia privilegiada é a aprendizagem colaborativa e na segunda a estratégia privilegiada é a aprendizagem cooperativa. Essa diferença pode ser explicada pelo fato de a área de Ciências privilegiar o Ensino Fundamental, no qual há resistência dos docentes e alunos, que se sentem desconfortáveis frente a atividades não tradicionais, dentre elas a aprendizagem cooperativa, como afirmado pelos pesquisadores (GARCÍA; TUÑÓN, 2004, ANDERSON; MITCHELL; OSGOOD, 2005). Essas dificuldades não são relatadas de forma tão incisiva no Ensino Superior, em relação ao qual encontramos o maior número de trabalhos destinados à área de Química.

A dificuldade no uso da aprendizagem cooperativa na área de Ciências, em consequência, no Ensino Fundamental, é sempre relacionada com sua estrutura, já que o uso da atividade cooperativa não implica simplesmente em organizar os alunos em grupos, mas exige uma preparação do docente, como apontado por Johnson, Johnson e Holubec (1999). Entretanto, essas barreiras devem ser superadas, já que muitos pesquisadores relatam que tanto a aprendizagem cooperativa quanto a colaborativa devem ser introduzidas o quanto antes na vida 
dos estudantes (COCHITO, 2004; BARBOSA; JÓFILI, 2004; JOHNSON; JOHNSON; SMITH, 2007; COSTA; OLIVEIRA; ALVES, 2008; THURSTON et al., 2010).

Nesse contexto, fica evidente que os trabalhos voltados para área de Ciências são de suma importância, já que, a inserção de hábitos cooperativos e colaborativos nos primeiros anos da formação dos estudantes poderá ajudar no desenvolvimento de habilidades sociais podendo inclusive ajudá-los na passagem de um nível de ensino para o outro (THURSTON et al., 2010).

\subsubsection{A produção e sua distribuição de acordo com o foco temático}

A análise dos trabalhos internacionais permitiu a determinação dos focos temáticos mais recorrentes que são descritos brevemente a seguir.

- Aprendizagem cooperativa ou colaborativa e suas possibilidades: trabalhos que discutem as contribuições acadêmicas provenientes do uso de estratégias baseadas nos preceitos da aprendizagem cooperativa ou baseados nos preceitos da aprendizagem colaborativa;

- Aprendizagem cooperativa ou colaborativa e suas estratégias específicas: trabalhos que discutem o uso de um método específico de aprendizagem cooperativa ou colaborativa, como jigsaw, PLTL, entre outros;

- Aprendizagem cooperativa ou colaborativa em parceria com outras metodologias: trabalhos que discutem as contribuições da aprendizagem cooperativa ou colaborativa quando usadas em parceria com outras metodologias de ensino/recursos didáticos;

- Aprendizagem cooperativa ou colaborativa apresentada em perspectiva teórica: trabalhos que apresentam considerações exclusivamente teóricas sobre a aprendizagem cooperativa ou colaborativa.

A Tabela 3 apresenta a classificação de cada um dos referidos trabalhos de acordo com a área de enfoque, nível educacional e foco temático, aspectos a serem discutidos nos tópicos seguintes. Os números atribuídos aos trabalhos correspondem à numeração dos trabalhos na Tabela 2. Doravante, os trabalhos serão referenciados por seus respectivos números. 
Tabela 3 - Classificação dos trabalhos de acordo com a área de pesquisa, nível educacional e foco temático, em que $\mathrm{F}=$ Fundamental, $\mathrm{M}=$ =Médio, $\mathrm{S}=$ Superior e $\mathrm{G}=\mathrm{Geral}$.

(continua)

\begin{tabular}{|c|c|c|c|}
\hline $\mathbf{N}^{\circ}$ & Área & Nível & Foco temático/Abordagem \\
\hline 1 & Biologia & G & $\begin{array}{l}\text { Aprendizagem cooperativa apresentado em perspectiva } \\
\text { teórica }\end{array}$ \\
\hline 2 & Biologia & S & Aprendizagem cooperativa e suas possibilidades \\
\hline 3 & Biologia & S & $\begin{array}{l}\text { Aprendizagem cooperativa em parceria com outras } \\
\text { estratégias }\end{array}$ \\
\hline 4 & Biologia & S & Aprendizagem colaborativa e suas estratégias específicas \\
\hline 5 & Biologia & S & Aprendizagem colaborativa e suas estratégias específicas \\
\hline 6 & Biologia & S & $\begin{array}{l}\text { Aprendizagem colaborativa apresentada em perspectiva } \\
\text { teórica }\end{array}$ \\
\hline 7 & Biologia & S & Aprendizagem colaborativa e suas possibilidades \\
\hline 8 & Química & M & Aprendizagem cooperativa e suas possibilidades \\
\hline 9 & Ciências & M & Aprendizagem colaborativa e suas possibilidades \\
\hline 10 & Ciências & M & Aprendizagem colaborativa e suas possibilidades \\
\hline 11 & Ciências & $\mathrm{F}$ & Aprendizagem colaborativa e suas possibilidades \\
\hline 12 & Ciências & M & Aprendizagem colaborativa e suas possibilidades \\
\hline 13 & Física & M & Aprendizagem colaborativa e suas possibilidades \\
\hline 14 & Biologia & M & Aprendizagem cooperativa e suas estratégias específicas \\
\hline 15 & Física & M & Aprendizagem colaborativa e suas possibilidades \\
\hline 16 & Química & S & Aprendizagem cooperativa e suas possibilidades \\
\hline 17 & Biologia & $\mathrm{F}$ & $\begin{array}{l}\text { Aprendizagem colaborativa em parceria com outras } \\
\text { estratégias }\end{array}$ \\
\hline 18 & Ciências & $\mathrm{F}$ & Aprendizagem colaborativa e suas possibilidades \\
\hline 19 & Química & G & Aprendizagem cooperativa e suas estratégias específicas \\
\hline 20 & Física & M & $\begin{array}{l}\text { Aprendizagem colaborativa em parceria com outras } \\
\text { estratégias }\end{array}$ \\
\hline 21 & Ciências & $\mathrm{F}$ & $\begin{array}{l}\text { Aprendizagem colaborativa em parceria com outras } \\
\text { estratégias }\end{array}$ \\
\hline 22 & Física & M & Aprendizagem colaborativa e suas possibilidades \\
\hline 23 & Ciências & $\mathrm{F}$ & Aprendizagem colaborativa e suas possibilidades \\
\hline 24 & Física & M & Aprendizagem cooperativa e suas estratégias específicas \\
\hline 25 & Ciências & G & Aprendizagem cooperativa e suas possibilidades \\
\hline 26 & Ciências & G & $\begin{array}{l}\text { Aprendizagem colaborativa apresentada em perspectiva } \\
\text { teórica }\end{array}$ \\
\hline 27 & Ciências & M & Aprendizagem colaborativa e suas possibilidades \\
\hline 28 & Química & G & Aprendizagem colaborativa e suas possibilidades \\
\hline 29 & Química & M & $\begin{array}{l}\text { Aprendizagem colaborativa em parceria com } \\
\text { estratégias }\end{array}$ \\
\hline 30 & Biologia & $\mathrm{F}$ & Aprendizagem cooperativa e estratégias específicas \\
\hline 31 & Ciências & G & Aprendizagem colaborativa e suas possibilidades \\
\hline 32 & Física & S & Aprendizagem colaborativa e suas possibilidades \\
\hline 33 & Física & S & Aprendizagem cooperativa e suas possibilidades \\
\hline 34 & Física & S & Aprendizagem cooperativa e suas possibilidades \\
\hline 35 & Física & $\mathrm{S}$ & Aprendizagem cooperativa e suas possibilidades \\
\hline 36 & Física & S & Aprendizagem colaborativa e suas possibilidades \\
\hline
\end{tabular}


Tabela 3 - Classificação dos trabalhos de acordo com a área de pesquisa, nível educacional e foco temático, em que $\mathrm{F}=$ Fundamental, $\mathrm{M}=$ Médio, $\mathrm{S}=$ Superior e $\mathrm{G}=\mathrm{Geral}$.

(conclusão)

\begin{tabular}{|c|c|c|c|}
\hline $\mathbf{N}^{\circ}$ & Área & Nível & Foco temático/Abordagem \\
\hline 37 & Física & $\mathrm{S}$ & $\begin{array}{l}\text { Aprendizagem colaborativa em parceria com outras } \\
\text { estratégias }\end{array}$ \\
\hline 38 & Física & S & Aprendizagem colaborativa e suas possibilidades \\
\hline 39 & Ciências & G & Aprendizagem colaborativa e suas possibilidades \\
\hline 40 & Química & $S$ & $\begin{array}{l}\text { Aprendizagem cooperativa em parceria com outras } \\
\text { estratégias }\end{array}$ \\
\hline 41 & Física & S & Aprendizagem cooperativa e suas possibilidades \\
\hline 42 & Química & S & Aprendizagem cooperativa e suas possibilidades \\
\hline 43 & Química & $\mathrm{S}$ & $\begin{array}{l}\text { Aprendizagem cooperativa em parceria com outras } \\
\text { estratégias }\end{array}$ \\
\hline 44 & Química & $\mathrm{s}$ & $\begin{array}{l}\text { Aprendizagem colaborativa apresentada em perspectiva } \\
\text { teórica }\end{array}$ \\
\hline 45 & Física & M & Aprendizagem cooperativa e suas possibilidades \\
\hline 46 & Química & S & Aprendizagem cooperativa e suas possibilidades \\
\hline 47 & Ciências & $\mathrm{F}$ & Aprendizagem colaborativa e suas possibilidades \\
\hline 48 & Biologia & S & $\begin{array}{l}\text { Aprendizagem colaborativa em parceria com outras } \\
\text { estratégias }\end{array}$ \\
\hline 49 & Física & $\mathrm{S}$ & $\begin{array}{l}\text { Aprendizagem colaborativa em parceria com outras } \\
\text { estratégias }\end{array}$ \\
\hline 50 & Ciências & $\mathrm{F}$ & Aprendizagem cooperativa e suas estratégias específicas \\
\hline 51 & Física & S & Aprendizagem cooperativa e suas possibilidades \\
\hline 52 & Química & S & Aprendizagem cooperativa e suas estratégias específicas \\
\hline 53 & Ciências & $\mathrm{F}$ & Aprendizagem cooperativa e suas estratégias específicas \\
\hline 54 & Química & $\mathrm{s}$ & $\begin{array}{l}\text { Aprendizagem cooperativa apresentada em perspectiva } \\
\text { teórica }\end{array}$ \\
\hline 55 & Química & $\mathrm{S}$ & $\begin{array}{l}\text { Aprendizagem cooperativa em parceria com outras } \\
\text { estratégias }\end{array}$ \\
\hline 56 & Física & S & Aprendizagem cooperativa e suas possibilidades \\
\hline 57 & Física & S & Aprendizagem cooperativa e suas estratégias específicas \\
\hline 58 & Física & $\mathrm{M}$ & Aprendizagem cooperativa e suas estratégias específicas \\
\hline 59 & Física & $S$ & $\begin{array}{l}\text { Aprendizagem cooperativa em parceria com outras } \\
\text { estratégias }\end{array}$ \\
\hline 60 & Biologia & G & $\begin{array}{l}\text { Aprendizagem colaborativa apresentada em perspectiva } \\
\text { teórica }\end{array}$ \\
\hline 61 & Biologia & $\mathrm{M}$ & $\begin{array}{l}\text { Aprendizagem colaborativa em parceria com outras } \\
\text { estratégias }\end{array}$ \\
\hline 62 & Química & $\mathrm{M}$ & $\begin{array}{l}\text { Aprendizagem colaborativa em parceria com outras } \\
\text { estratégias }\end{array}$ \\
\hline 63 & Física & $\mathrm{M}$ & Aprendizagem colaborativa e suas possibilidades \\
\hline
\end{tabular}




\section{Aprendizagem cooperativa e suas possibilidades}

Dentre os 29 trabalhos internacionais sobre aprendizagem cooperativa, treze $(2,8,16,25,33,34,35,41,42,45,46,51$ e 56) tratam especificamente de experiências voltadas à análise das possibilidades da aprendizagem cooperativa, mas há outros que, apesar de classificados em outros focos temáticos, tratam de forma secundária da aprendizagem cooperativa e suas possibilidades.

Dentre os 29 trabalhos mencionados, os trabalhos 45 e 46 apontaram a adoção da aprendizagem cooperativa como promotora de um ambiente em que os alunos produzem melhores respostas aos problemas propostos e, consequentemente, têm seu desempenho acadêmico aperfeiçoado.

Nesse contexto, ainda pode-se destacar que o melhor desempenho acadêmico dos alunos relacionou-se diretamente à interação proporcionada pela atividade, que criou uma interdependência positiva, fazendo com que trabalhassem pensando no grupo como um todo, melhorando sua interação durante as atividades. Tal método revelou-se capaz de tornar o aluno responsável pela sua aprendizagem e com a possibilidade de contar com seus pares para sua melhor formação.

Alguns trabalhos, como os de números 45 e 51, apontaram como ponto forte da atividade o alto grau de aprovação dos alunos que dela participaram, relacionando essa aprovação com o fato de a atividade criar um ambiente mais motivador para os alunos. Simultaneamente, os artigos afirmam que o ensino de Ciências deve ser modificado para acompanhar a sociedade, que está em constante mutação, em contraposição ao Ensino de Ciências, que permanece sem alterações relevantes. A aprendizagem cooperativa é descrita como alternativa para uma educação mais dinâmica e interativa.

Outros trabalhos, como o de número 2, apresentaram como objetivo avaliar as contribuições da aprendizagem cooperativa em turmas numerosas, chegando a resultados que apontam para uma melhoria no desempenho dos alunos. Os autores indicam que a aula expositiva não é capaz de envolver o aluno e nem de promover aprendizagem efetiva, quadro que se agrava quando as turmas são formadas por um número elevado de alunos. Dessa forma, a aprendizagem cooperativa surge como forma paliativa para reverter essa situação, melhorando a interação dos alunos durante as atividades e promovendo uma aprendizagem mais rica. 
No trabalho 16, diferentemente dos demais, os autores afirmaram que as atividades cooperativas não ajudaram a melhorar o desempenho dos alunos. Entretanto, estes não conseguiram indicar pontos negativos que desqualificassem a atividade cooperativa. Somados a tais resultados, alguns autores apontam as dificuldades para a implementação das atividades cooperativas em sala de aula, tanto por parte dos professores, que se mostram resistentes a mudanças, quanto por parte dos alunos, que se sentem desconfortáveis frente a uma atividade não tradicional. Essa perspectiva é fruto de uma visão tradicional de ensino que fica arraigada nos alunos desde seus primeiros anos na escola. Porém, como mencionado no trabalho 45 , mesmo diante das dificuldades apontadas, a visão dos alunos pós-atividade é positiva, sendo apontada a motivação gerada pela atividade como seu ponto alto.

\section{Aprendizagem colaborativa e suas possibilidades}

Dentre os 34 trabalhos internacionais sobre aprendizagem colaborativa, dezenove $(7,9,10,11,12,13,15,18,22,23,27,28,31,32,36,38,39,47$ e 63) tratam de experiências voltadas à análise das possibilidades da aprendizagem colaborativa.

Os autores dos trabalhos 27 e 47 apontaram a adoção da aprendizagem colaborativa como uma alternativa na busca de um posicionamento mais positivo dos alunos frente à Ciência, verificando-se ainda sua capacidade na diminuição da ansiedade e no aumento da motivação no estudo de conteúdos dessa natureza.

Os trabalhos 11 e 15 tiveram como foco de pesquisa as diferenças de gênero e raça no desenvolvimento do trabalho colaborativo e concluíram que resultados positivos independem de sexo e raça, sendo apontada apenas uma diferença no trabalho de grupos de gêneros diferentes, que demonstram que os meninos apresentam melhor desempenho nas atividades práticas de laboratório, entretanto o desempenho não se traduz em melhor resultado acadêmico.

Uma perspectiva diferente é apresentada no trabalho 38, no qual é feita uma avaliação negativa do uso do trabalho em grupo. Nele, é apontada a dificuldade em transferir para o aluno o domínio sobre sua aprendizagem, seja por receio de sua imaturidade ou por medo de comprometer-se à aprendizagem individual. De forma complementar, existem artigos, como os de números 18 e 39, nos quais ocorre a 
introdução da temática da aprendizagem colaborativa na formação inicial e continuada de professores. Trabalhos dessa natureza apresentam como resultados positivos o alcance de objetivos como o desenvolvimento de habilidades sociais dos professores, que, no futuro, serão capazes de fomentá-las em sala de aula.

Por fim, no trabalho 7, os autores afirmam que o desempenho acadêmico dos alunos nos grupos colaborativos é superior ao desempenho individual. Entretanto, os resultados obtidos em testes posteriores demonstraram que essa diferença só é perceptível imediatamente após a realização da atividade e, com o passar do tempo, ela torna-se insignificante.

\section{Aprendizagem cooperativa e suas estratégias especificas}

Os trabalhos $14,19,24,30,50,52,53,57$ e 58 foram classificados neste foco temático, sendo o método jigsaw objeto central na maioria dos textos. Apenas o texto de número 50 apresenta como estratégia cooperativa o método STAD, desenvolvidos por Slavin (1983), que usa o fator motivacional como elemento facilitador do processo de ensino-aprendizagem. Segundo Slavin, o rendimento aumenta com a aprendizagem cooperativa se e quando existir uma recompensa pelo trabalho de grupo e, ao mesmo tempo, se cada aluno for responsabilizado pela sua própria aprendizagem. A pesquisa em questão foi realizada com vinte alunos do Ensino Fundamental, que participaram de dois testes (um pré-teste e um pós-teste) com o objetivo de verificar o desenvolvimento dos alunos no conteúdo aplicado e também no seu autoconhecimento. Como resultado, os autores perceberam uma melhora significativa no desempenho dos alunos, tanto nas questões voltadas para o conteúdo, quanto nas questões voltadas para seu autoconhecimento. Como justificativa para os resultados encontrados, os autores apontam a capacidade que essa estratégia possui de fazer o aluno participar mais ativamente do processo. Os autores também relatam a importância do uso de grupos heterogêneos, apontados como fator motivador, inclusivo e gerador de perspectivas comuns. Aspecto importante se considerarmos que, na Ciência, raramente uma grande ideia surge de esforço individual.

Os trabalhos 30 e 53, voltados para o Ensino Fundamental, chamam atenção para a quantidade de equívocos gerados durante a aprendizagem de Ciências nesta 
etapa, lembrando que os alunos consideram os conceitos de Ciências de difícil compreensão e de elevado grau de abstração. Assim, apresentam o método jigsaw como uma possibilidade para o desenvolvimento de habilidades de comunicação e facilitando a aprendizagem dos conceitos de Ciências. Para tanto, os autores do trabalho 53 comparam uma atividade cooperativa frente a uma atividade tradicional, realizando um teste de verificação e, ao término das atividades, realizaram uma entrevista para identificar possíveis concepções alternativas. Como resultado, concluíram que os alunos participantes da atividade cooperativa desenvolveram melhor os conceitos e o número de concepções alternativas relatados foi consideravelmente menor do que o encontrado para o grupo de controle. Já os autores do trabalho 30 chamam atenção para uma aprendizagem que se apoie na argumentação e na construção coletiva do conhecimento, fatores normalmente ignorados nos métodos de aprendizagem tradicionais.

Os trabalhos 14, 24 e 58 trataram do uso do método jigsaw no Ensino Médio, sendo dois em disciplina de Física (trabalhos 24 e 58) e um em disciplina de Biologia (trabalho 14). O artigo 24 investigou a capacidade motivacional do jigsaw frente a outra atividade de grupo, apontando como fator positivo da metodologia a potencialidade de tornar os alunos mais ativos e acentuar a sua motivação. Entretanto, apesar de positivos, os resultados não foram tão significativos com relação ao desempenho acadêmico dos alunos. Já o trabalho 58 apontou como principal característica do jigsaw o trabalho com pares, que pode ser benéfico pela proximidade maior existente entre eles, sendo o método também eficiente no estudo de equações matemáticas, que exigem uma participação mais ativa dos alunos. No artigo 14 foram comparados os resultados de duas atividades em disciplina de Biologia, uma cooperativa jigsaw e outra tradicional, encontrando como resultado do pós-teste um desempenho melhor para os alunos que participaram da atividade cooperativa, porém os autores apontaram a necessidade de pesquisas futuras para subsidiar os resultados encontrados.

Os artigos 52 e 57 tiveram como público alvo os alunos do Ensino Superior. Em ambos os casos, os autores tentaram verificar a influência da metodologia na compreensão e retenção dos conceitos de Química e Física. Os alunos que participaram das atividades cooperativas obtiveram resultados superiores aos que participaram dos métodos tradicionais. Cabe ressaltar que no artigo 57 os autores chamam a atenção para a utilização de grupos heterogêneos que podem evitar que 
os alunos se apropriem de conceitos errados, normalmente verificados na aprendizagem tradicional.

Os autores do trabalho 19 relataram três casos em que o trabalho cooperativo jigsaw foi utilizado como metodologia principal, em diferentes níveis e com alunos de idades distintas. Encontraram resultados positivos em suas pesquisas, denotando a importância do uso do trabalho de grupo pelo seu caráter social e revelando que a aprendizagem cooperativa tem que ser vista não como um fim, e sim como um meio para o processo de ensino-aprendizagem, repleta de possibilidades, que devem se adequar aos conteúdos que se quer ensinar e ao seu público alvo. Apontam ainda a liderança e a motivação como pontos chaves para a metodologia jigsaw.

\section{Aprendizagem colaborativa e suas estratégias específicas}

Para este foco, encontramos os trabalhos 4 e 5, que visam investigar atividades de grupo colaborativas no Ensino Superior de Biologia. No trabalho 4, a estratégia apresentada é uma variação do PLTL. O objetivo do trabalho foi verificar a eficiência das oficinas de pares, que se caracteriza por atividades em grupo lideradas por um aluno aprovado anteriormente na disciplina, ministrada em horários extraclasse com o intuito de melhorar o desempenho dos alunos provenientes de salas numerosas, também verificando a interferência dos gêneros e da origem dos alunos em pré-teste e pós-teste. Os resultados encontrados demonstraram que os alunos aceitaram positivamente o uso das oficinas, tendo as meninas adquirido os resultados mais positivos. Outro fator relevante foi o impacto mais efetivo nos alunos autodeclarados de minorias sociais.

No trabalho 5, encontramos outra estratégia derivada do PLTL, denominada Teaching Team Program (TTP), utilizada com o objetivo de facilitar o processo de ensino-aprendizagem para as turmas numerosas e com número elevado de retenções. A maior diferença frente ao PLTL é que o programa conta com grupos de estudos em que os alunos decidem o que estudam e como estudam, diferentemente do PLTL, no qual quem decide o que e como vai ser estudado é o líder do grupo. Como resultado da atividade, nos dois semestres em que foi levada a cabo, o número de retenções e abandonos no curso diminuiu. Entretanto, o resultado encontrado no segundo semestre da atividade foi muito inferior, o que levou os 
pesquisadores a questionarem a efetividade da atividade. Como justificativa para esse resultado, os autores apontaram a formação do líder do grupo e também a formação prévia dos alunos que participaram da atividade no primeiro semestre como fatores críticos para o rendimento das atividades. Ressaltamos que um grupo de alunos sugeriu que atividades mais estruturadas poderiam evitar a diferença nos resultados já que consideram que os alunos não levaram a atividade tão a sério pela falta da organização.

\section{Aprendizagem cooperativa em parceria com outras estratégias}

Os trabalhos 3, 40, 43, 55 e 59 foram classificados neste foco temático. Nos trabalhos 3 e 59 são discutidos os benefícios da utilização da aprendizagem cooperativa combinada com aulas de laboratório. No trabalho 3, os autores verificaram a opinião dos alunos antes e depois do projeto. Como resultado, os alunos aprovaram a combinação das atividades. Além da percepção dos alunos, os resultados apontaram uma melhora nas suas notas médias. Ficou claro, a partir desses resultados, que os alunos se sentiram mais responsáveis pela sua aprendizagem, o que levou a uma melhor assimilação dos conceitos específicos de Microbiologia. No trabalho 59, foi relatada uma atividade de laboratório de Física combinada com uma atividade cooperativa, com o objetivo de demonstrar a importância do laboratório no desenvolvimento de habilidades motoras dos alunos. Simultaneamente, os autores verificaram a atividade cooperativa frente a um grupo de controle para comparar os resultados acadêmicos. Como resultado, apontaram a importância da atividade para o desenvolvimento social e motor dos alunos, porém não encontraram diferença significativa no desempenho acadêmico nos diferentes grupos.

Nos trabalhos 40 e 55, desenvolvidos pelos mesmos autores, são discutidos benefícios decorrentes do uso de recursos computacionais associados a estratégias cooperativas no Ensino Superior de Química. Com o uso das tecnologias da informação e comunicação (TIC) os autores afirmam que conseguiram minimizar as limitações de espaço e tempo, com o enriquecimento da aquisição de conhecimento dos alunos. No trabalho 40 os autores apontam duas dificuldades no uso das tecnologias: primeiro, a falta de preparo por parte dos docentes; em segundo lugar, 
o trabalho exigido, que é superior ao de uma aula convencional e nem sempre garante resultados positivos.

No trabalho 43 os autores apresentaram uma atividade que combinava atividades cooperativas com aulas expositivas. Os resultados encontrados demonstram que os alunos melhoraram seus resultados acadêmicos, se comparados com os alunos que participaram somente de aulas expositivas. Apontaram ainda uma boa aceitação dos alunos frente ao método utilizado. Com ele, os alunos se mostraram mais satisfeitos em participar do processo de ensinoaprendizagem.

\section{Aprendizagem colaborativa em parceria com outras estratégias}

Os trabalhos $17,20,21,29,37,48,49,61$ e 62 foram classificados neste foco temático. No trabalho 17 são discutidos os benefícios da utilização da aprendizagem colaborativa em aulas de laboratório. Em particular, neste artigo encontramos grupos separados por gênero e também grupos mistos, tendo como resultados os benefícios na área da comunicação verbal e indícios de que o gênero não interfere no resultado das atividades.

Nos trabalhos 20, 21, 48, 49 e 61 são discutidos benefícios decorrentes do uso de recursos computacionais associados a técnicas colaborativas. No trabalho 20 participaram alunos do Ensino Médio em disciplina de Física os pesquisadores verificaram como os alunos usam um programa de multimídia para descobrir como funcionam as lentes e os espelhos. O trabalho é feito de forma colaborativa, com pré-teste, a atividade baseada no programa e um pós-teste. Os pesquisadores obtiveram como resultado uma melhora na compreensão do conteúdo, o que sugere o papel do computador como mediador no processo colaborativo, nos trabalhos 21 e 61 em disciplina de Física e Biologia, respectivamente, os autores trabalham com os programas de computador de forma a auxiliar e facilitar a cooperação entre os grupos.

Nos trabalhos 48 e 49 encontramos a aprendizagem colaborativa associada a recursos computacionais no Ensino Superior, nas disciplinas de Biologia e Física respectivamente, ressaltando a importância da colaboração na formação dos 
professores, sendo capazes de aproximá-los dos seus alunos no processo de ensino-aprendizagem.

Nos trabalhos 29 e 37 encontramos a aprendizagem colaborativa associada a atividades de laboratórios, sendo uma desenvolvida no Ensino Médio de Química e outro no Ensino Superior de Física. No Ensino Médio de Química, os pesquisadores compararam três situações diferentes: na primeira, os alunos trabalharam no laboratório individualmente; na segunda, os alunos trabalharam em grupos colaborativos; e na terceira, trabalharam de forma colaborativa, com a supervisão de um monitor. Os resultados apontaram que, nas duas atividades colaborativas, os alunos apresentaram resultados melhores do que os que participaram da atividade individual. Para chegar a essa conclusão foram analisados os relatórios desenvolvidos pelos alunos e um pós-teste. Também ficou registrado que as atividades colaborativas não apresentaram diferenças significativas entre elas em curto prazo, mas em longo prazo a atividade colaborativa monitorada superou em resultados a sem monitoramento. Já no trabalho 37 encontramos a aprendizagem colaborativa usada simultaneamente com aulas expositivas e atividades no laboratório. O resultado foi considerado positivo, já que os alunos participantes tiveram melhor desempenho do que os dos cursos tradicionais. O número de desistência do curso de Física também diminuiu e o número de alunos participantes das atividades, que eram opcionais, aumentou durante a realização do projeto. Como motivo para os resultados, os pesquisadores não conseguiram apontar uma tendência única, mas, entre outros aspectos, indicaram a participação mais ativa dos alunos como fator motivador mais relevante.

No trabalho 62 os autores apresentam uma atividade colaborativa realizada em parceria com a construção de mapas conceituais. O trabalho foi realizado com a comparação de quatro grupos de análises, dois de trabalhos individuais e dois colaborativos, sendo que nos grupos colaborativos, um trabalhou com a realização de mapas conceituais e o outro só observou os mapas conceituais. O mesmo foi feito com alunos que trabalhavam individualmente. Os resultados demonstraram que os alunos que trabalharam de forma colaborativa tiveram melhores resultados, independentes dos mapas conceituais. Já quando analisado o trabalho individual, os que usaram os mapas tiveram melhores resultados do que aqueles que só observaram. Os alunos que participaram das atividades colaborativas assimilaram melhor os conceitos e tiveram melhores resultados nas avaliações, com nota cerca 
de $20 \%$ maior do que aqueles que trabalharam individualmente. Já com relação aos que fizeram e os que só observaram os mapas conceituais, os que realizaram tiveram notas maiores.

\section{Aprendizagem cooperativa apresentada em perspectiva teórica}

Os trabalhos 1 e 54 foram classificados nesta categoria. Os autores do trabalho 1 recorrem à análise de diversos artigos e fazem uso dos resultados encontrados para recomendar a utilização da aprendizagem cooperativa para os diversos níveis do ensino na área de Biologia, considerando a aprendizagem cooperativa como uma alternativa capaz de aproximar a realidade da sala de aula à prática vivida pelos profissionais de Biologia, que em seu trabalho realizam atividades de forma colaborativa e não individual.

Além disso, o texto aponta que esse tipo de estratégia melhora o comportamento dos alunos e simultaneamente fortalece 0 processo de aprendizagem. Os autores chamam atenção para o fato de a aprendizagem cooperativa exigir um grande conhecimento do professor que vai utilizá-la e da necessidade de sua introdução gradativa e pontual já nos primeiros níveis educacionais, passando por atividades semiestruturadas até chegar em atividades mais estruturadas e complexas. Cabe lembrar que os autores afirmam que definir a aprendizagem cooperativa simplesmente observando o significado das palavras que a denominam é um erro, pois denota uma simplicidade que não existe nessa prática. $\mathrm{O}$ trabalho em aprendizagem cooperativa envolve uma estrutura pré-determinada e se pauta na realização de pesquisas que buscaram materiais e meios capazes de tornar a aprendizagem grupal mais efetiva.

No trabalho 54 os autores apresentam um método que tem como objetivo oferecer suporte para que os professores possam avaliar seus alunos individualmente, mesmo quando estiverem realizando atividades cooperativas. A preocupação com o assunto se justifica, tendo em vista que a responsabilidade individual é uma condição crucial para o sucesso ou o fracasso do trabalho em grupo cooperativo. Os autores apontam a avaliação como uma forma de garantir que os alunos tenham mais responsabilidade. 


\section{Aprendizagem colaborativa apresentada em perspectiva teórica}

Os trabalhos $6,26,44$, e 60 foram classificados nesta categoria. O artigo 6 apresenta uma investigação com o objetivo de verificar qual o tipo de grupo (homogêneo ou heterogêneo) apresenta mais vantagens para a realização de trabalhos colaborativos. Na perspectiva dos autores os grupos homogêneos são mais indicados, pois permitem que os alunos considerados de baixo rendimento participem de forma plena, já que em grupos heterogêneos eles não teriam condições de discutir em condições iguais.

O trabalho 26 apresenta uma análise teórica do funcionamento de uma rede de colaboração científica denominada NetColL. Para tanto, os pesquisadores verificam o funcionamento das ferramentas do programa, as metodologias utilizadas e os desafios descritos pelos professores, terminando por descreverem indicações positivas e também limitações da rede em questão.

O trabalho 60 apresenta uma revisão de artigos que mostra a importância do trabalho em grupo e discute a relevância do papel do professor na atividade colaborativa, deixando evidente que a sua participação nas atividades colaborativas tem que ser ativa, sendo ele o grande responsável pela organização e condução das ações, podendo determinar o sucesso e o fracasso do grupo.

O trabalho 44 apresenta dez razões negativas apontadas pelos alunos na realização de atividades colaborativas. Apesar da existência das dificuldades, o autor indica que o uso da atividade colaborativa deve prevalecer independente dos obstáculos encontrados em sala e da opinião dos alunos.

\subsubsection{Aprendizagem Cooperativa e Colaborativa: Âmbito Nacional}

$\mathrm{Na}$ Tabela 4 é apresentado um total de sete revistas nacionais nas quais encontramos trabalhos sobre a temática. Nela consta o período em que o levantamento foi realizado, bem como a quantidade de trabalhos localizados por revista. Ressaltamos que o período de pesquisa foi variável, seguindo a disponibilidade de cada uma das revistas. 
Tabela 4 - Revistas nacionais analisadas, os respectivos períodos em que o levantamento foi realizado e a quantidade de trabalhos localizados em cada uma delas.

\begin{tabular}{lcc}
\hline Periódicos & Período & N$^{\circ}$ de trabalhos \\
\hline Ciência e Educação & 1975 a 2013 & 7 \\
Experiência em Ensino de Ciência & 2006 a 2013 & 2 \\
$\begin{array}{l}\text { Revista Brasileira de Pesquisa em } \\
\text { Educação em Ciências }\end{array}$ & 2001 a 2013 & 2 \\
$\begin{array}{l}\text { Ensaio: Pesquisa em Educação em } \\
\text { Ciências }\end{array}$ & 1999 a 2013 & 1 \\
Revista Brasileira de Ensino de Física & 1978 a 2013 & 1 \\
Revista Química Nova na Escola & 1995 a 2013 & 3 \\
Revista Química Nova & 1978 a 2013 & 1 \\
Total & & 17 \\
\hline
\end{tabular}

$\mathrm{Na}$ Tabela 5 listamos os trabalhos encontrados sobre o tema nas revistas referidas acima, em ordem cronológica de publicação. Os artigos relativos à aprendizagem cooperativa encontram-se sombreados, diversamente dos relativos à aprendizagem colaborativa.

Tabela 5 - Artigos sobre aprendizagem cooperativa sombreados e artigos sobre aprendizagem colaborativa não sombreados, localizados em revistas brasileiras.

(continua)

$\mathrm{N}^{\circ}$ Autor e Título Ano de

Publicação

Ciência e Educação

1 BAROLLI, E VILLANI, A. O trabalho em grupos no laboratório 2000 didático: reflexões a partir de um referencial psicanalítico

2 MARTINS, S. T. F. Educação e atividade grupal na perspectiva 2002 sócio-histórica

3 BARBOSA, R. $\quad$ M. N.; JÓFILI, Z. M. $\quad$ S. Aprendizagem 2004 cooperativa e ensino de química - parceria que dá certo

4 BARROS, M. A.; LABURÚ, C. E.; ROCHA, Z. F. D. C. Análise 2007 do vínculo entre grupo e professora numa aula de ciências do Ensino Fundamental

5 SILVA, G. S. F.; VILLANI, A. Grupos de aprendizagem nas 2009 aulas de física: as interações entre professores e alunos

6 JULIO, J; VAZ, A.; FAGUNDES, A. Atenção: alunos engajados - 2011 análise de um grupo de aprendizagem em atividade de investigação 
Tabela 5 - Artigos sobre aprendizagem cooperativa sombreados e artigos sobre aprendizagem colaborativa não sombreados, localizados em revistas brasileiras.

\begin{tabular}{|c|c|c|}
\hline $\mathrm{N}^{\circ}$ & Autor e Título & $\begin{array}{c}\text { (conclusão) } \\
\text { Ano de } \\
\text { Publicação }\end{array}$ \\
\hline 7 & $\begin{array}{l}\text { NASCIMENTO, J. M.; AMARAL, E. M. R. O papel das interações } \\
\text { sociais e de atividades propostas para o ensino - aprendizagem } \\
\text { de conceitos químicos }\end{array}$ & 2012 \\
\hline \multicolumn{3}{|c|}{ Experiência em Ensino de Ciência } \\
\hline 8 & $\begin{array}{l}\text { CAVALHEIRO, P.; DEL PINO, J. C.. Aprendizagem e } \\
\text { cooperação em atividades de monitoria para o ensino de } \\
\text { ciências no nível fundamental }\end{array}$ & 2007 \\
\hline 9 & $\begin{array}{l}\text { INFANTE-MALACHIAS, M. E.; NAVAS, A.M., NUNES, C. A. A.; } \\
\text { SANTOS-GOUW, A. M. P.; FEJES, M. E. Elaboração em grupo } \\
\text { de roteiros de simulações de química: uma aproximação à } \\
\text { aprendizagem significativa colaborativa }\end{array}$ & 2007 \\
\hline \multicolumn{3}{|c|}{ Revista Brasileira de Pesquisa em Educação em Ciências } \\
\hline 10 & $\begin{array}{l}\text { BARROS, M. A.; BAROLLI, E.; VILLANI, A. A evolução de um } \\
\text { grupo de aprendizagem num curso de física de Ensino Médio }\end{array}$ & 2001 \\
\hline 11 & $\begin{array}{l}\text { QUEIROZ, M. P.; BARBOSA, R. M. N.; AMARAL E. M. R.. Uma } \\
\text { análise de interações discursivas promovidas pela aplicação de } \\
\text { métodos cooperativos em aulas de química }\end{array}$ & 2009 \\
\hline \multicolumn{3}{|c|}{ Ensaio: Pesquisa em Educação em Ciências } \\
\hline & $\begin{array}{l}\text { PEREIRA, M. M. Interações discursivas em pequeno grupo } \\
\text { durante uma atividade investigativa sobre determinação da } \\
\text { aceleração da gravidade }\end{array}$ & 2013 \\
\hline \multicolumn{3}{|c|}{ Revista Brasileira de Ensino de Física } \\
\hline 13 & $\begin{array}{l}\text { LEITE, I. S.; LOURENÇO, A. B.; LICIO, J. G.; HERNANDES, A. } \\
\text { C. Uso do método cooperativo de aprendizagem jigsaw } \\
\text { adaptado ao ensino de nanociência e nanotecnologia }\end{array}$ & 2013 \\
\hline \multicolumn{3}{|c|}{ Química Nova na Escola } \\
\hline 14 & $\begin{array}{l}\text { RIBEIRO JÚNIOR, R. M.; ECHEVERRÍA, A. R. Grupos de } \\
\text { estudos entre estudantes ingressantes (calouros) e veteranos: } \\
\text { uma perspectiva alternativa de estudo e discussão na } \\
\text { universidade }\end{array}$ & 2009 \\
\hline 15 & $\begin{array}{l}\text { FATARELI, E. F.; FERREIRA, L. N. A.; FERREIRA, J. Q.; } \\
\text { QUEIROZ, S. L. Método cooperativo de aprendizagem jigsaw no } \\
\text { ensino de cinética química }\end{array}$ & 2010 \\
\hline 16 & $\begin{array}{l}\text { SILVA, V. A.; SOARES, M. H. F. B. Conhecimento prévio, } \\
\text { caráter histórico e conceitos científicos: o ensino de química a } \\
\text { partir de uma abordagem colaborativa da aprendizagem }\end{array}$ & 2013 \\
\hline \multicolumn{3}{|c|}{ Química Nova } \\
\hline 17 & $\begin{array}{l}\text { QUEIROZ, S. L.; MASSI, L.; CERRUTTI, B. M. Metodologia de } \\
\text { ensino jigsaw em disciplina de química medicinal }\end{array}$ & 2013 \\
\hline
\end{tabular}

$\mathrm{Na}$ Tabela 6 listamos os trabalhos encontrados sobre o tema nas edições dos ENPEC até 2013, em ordem cronológica de realização dos eventos. Os trabalhos 
relativos à aprendizagem cooperativa encontram-se sombreados, diversamente dos relativos à aprendizagem colaborativa.

Tabela 6 - Trabalhos completos apresentados nos ENPEC sobre aprendizagem cooperativa sombreados e artigos sobre aprendizagem colaborativa não sombreados.

III ENPEC - Atibaia, $2001 \quad$ Autores

(continua)

\begin{tabular}{ll}
\hline A evolução de um grupo de aprendizagem num curso & BARROS, M.A.; \\
de física de Ensino Médio & BARROLI, E.; \\
& VILLANI, A.
\end{tabular}

\section{ENPEC - Bauru, 2003}

Articulando os discursos de um professor de física com $\quad$ BARROS, M.A.;

19 a aprendizagem em grupo dos estudantes

ARRUDA, S.M.;

LABURÚ, C.E.;

VILLANI, A.

\begin{tabular}{lllll}
\hline Um referencial psicanalítico para os grupos de & $\begin{array}{c}\text { VALADARES, J.M.; } \\
\text { aprendizagem em ciências }\end{array}$
\end{tabular}

\section{ENPEC - Bauru, 2005}

O grupo de estudo como alternativa para a educação SILVA, E.L.; PACCA,

21 permanente e suas implicações para a prática docente J.L.A.

Grupos de aprendizagem: o papel da intervenção do GUIMARÃES, L.F.;

22 professor

SILVA, G.S.F.;

VILLANI, A.

23 O professor de física como "co-pensor" em "grupos JULIO, J.; VAZ, operativos" de alunos do Ensino Médio ${ }^{A}$

A.

Utilização de software interativo como ferramenta de MOREIRA, C.A.O.;

24 apoio ao ensino de gráfico em física, em um ambiente SANTOS, M.G.

de aprendizado interativo colaborativo

Trabalho em grupo: concepções práticas e ROSA, K.S.;

25 contribuições no curso de ciências biológicas BARCELOS,

N.N.S.

\begin{tabular}{llr}
\hline VI ENPEC - Florianópolis, 2007 & \\
\hline 26 & Aprender ciências em grupo: o que os alunos pensam? & $\begin{array}{c}\text { GUEDES, M.G.M.; } \\
\text { BARBOSA, R.M.N.; } \\
\text { JÓFILI, Z.M.S. }\end{array}$ \\
\hline & $\begin{array}{l}\text { Caracterização dos alunos-professores participantes da } \\
\text { pesquisa "formação inicial de professores de ciências e } \\
\text { biologia e o uso de computadores: análise de uma } \\
\text { prática colaborativa" }\end{array}$ & $\begin{array}{r}\text { GIANOTTO, D.E.P.; } \\
\text { DINIZ, R.E.S.; } \\
\text { MARICATO, F.E. }\end{array}$ \\
\hline $\begin{array}{l}\text { Algumas características adquiridas por professores em } \\
\text { formação continuada no trabalho em grupo }\end{array}$ & $\begin{array}{c}\text { SILVA, E.L.; } \\
\text { PACCA, J.L.A. }\end{array}$ \\
\hline 29 & $\begin{array}{l}\text { Atividades de investigação escolar em física: uma } \\
\text { análise psicanalista de pequenos grupos }\end{array}$ & JÚLIO, J.M.; \\
VAZ, A.M.
\end{tabular}


Tabela 6 - Trabalhos completos apresentados nos ENPEC sobre aprendizagem cooperativa sombreados e artigos sobre aprendizagem colaborativa não sombreados.

(conclusão)

\begin{tabular}{|c|c|c|}
\hline \multicolumn{2}{|c|}{ VII ENPEC - Florianópolis, 2009} & \multirow{2}{*}{$\begin{array}{c}\text { Autores } \\
\text { MELIM, L.M.C.; } \\
\text { SPIEGEL, C.N.; } \\
\text { ALVES, G.G.; LUZ, } \\
\text { M.R.M.P. }\end{array}$} \\
\hline 30 & $\begin{array}{l}\text { Cooperação ou competição? Avaliação de uma } \\
\text { estratégia lúdica de ensino de biologia para } \\
\text { estudantes do Ensino Médio }\end{array}$ & \\
\hline 31 & $\begin{array}{l}\text { Aprendizagem cooperativa no ensino de química: } \\
\text { uma proposta de abordagem em sala de aula }\end{array}$ & $\begin{array}{c}\text { SILVA, A. J.; GAUCHE } \\
\text { R. }\end{array}$ \\
\hline 32 & $\begin{array}{l}\text { Grupos de aprendizagem colaborativa como } \\
\text { ferramenta na reestruturação do pensamento e } \\
\text { desenvolvimento profissional do professor de química }\end{array}$ & $\begin{array}{l}\text { SANTOS JUNIOR; J.B. } \\
\text { MARCONDES, M.E.R. }\end{array}$ \\
\hline 33 & $\begin{array}{l}\text { O processo grupal nas aulas de física: a análise do } \\
\text { grupo da dependência }\end{array}$ & $\begin{array}{l}\text { SILVA, G.S.F.; } \\
\text { VILLANI, A. }\end{array}$ \\
\hline \multicolumn{3}{|c|}{ VIII ENPEC - Campinas, 2011} \\
\hline 34 & $\begin{array}{l}\text { A aprendizagem colaborativa: desenvolvimento de } \\
\text { conceitos químicos em nível médio de ensino }\end{array}$ & $\begin{array}{l}\text { SILVA, V.A.; } \\
\text { SOARES, M.H.F.B. }\end{array}$ \\
\hline 35 & $\begin{array}{l}\text { Panorama das pesquisas sobre aprendizagem } \\
\text { cooperativa no ensino de ciências }\end{array}$ & $\begin{array}{l}\text { TEODORO, D.L.; } \\
\text { QUEIROZ, S.L. }\end{array}$ \\
\hline 36 & $\begin{array}{l}\text { Engajamento cognitivo na física em função de } \\
\text { condutas dos alunos durante investigação em grupo }\end{array}$ & $\begin{array}{l}\text { FARIA, A.F.; VAZ, } \\
\text { A.M. }\end{array}$ \\
\hline 37 & $\begin{array}{l}\text { Aplicação de discussões on-line e estratégias de } \\
\text { aprendizagem cooperativa no Ensino Superior de } \\
\text { Química }\end{array}$ & $\begin{array}{l}\text { FERREIRA, J.Q.; } \\
\text { QUEIROZ, S.L. }\end{array}$ \\
\hline 38 & $\begin{array}{l}\text { Ensino de física moderna e contemporânea: o } \\
\text { trabalho em grupo como construção de atividade }\end{array}$ & $\begin{array}{l}\text { ARENGHI, L.E.B.; } \\
\text { CARVALHO, L.M.O.; } \\
\text { BORTOLETTO, A. }\end{array}$ \\
\hline \multicolumn{3}{|c|}{ IX ENPEC - Águas de Lindoia, 2013} \\
\hline 39 & $\begin{array}{l}\text { Grupo cooperativo: contribuições para o estágio } \\
\text { curricular supervisionado na educação a distancia } \\
\text { durante o CEK }\end{array}$ & $\begin{array}{l}\text { SILAVA, A.P.T.B; } \\
\text { BASTOS, H.F.B.N. }\end{array}$ \\
\hline 40 & $\begin{array}{l}\text { Diseño de una secuencia de enseñanza y } \\
\text { aprendizaje sobre electricidad para la promoción de } \\
\text { competências em ciências, basado em el aprendizaje } \\
\text { cooperativo }\end{array}$ & $\begin{array}{l}\text { ESPINOZA, J.S.; } \\
\text { RUBILAR, C.M. }\end{array}$ \\
\hline
\end{tabular}

A seguir apresentamos discussões acerca dos aspectos mencionados anteriormente, com relação aos trabalhos apresentados nas Tabelas 4 e 5. 


\subsubsection{A produção e sua distribuição no tempo}

Com base no levantamento bibliográfico realizado, observamos que questões ligadas à aprendizagem cooperativa e à aprendizagem colaborativa vêm sendo exploradas de forma constante nos últimos anos. Na Figura 4, apresentamos a frequência de trabalhos localizados nas revistas e nos anais dos ENPEC, de acordo com os períodos especificados nas Tabelas 5 e 6 .

Figura 4 - Quantidade de trabalhos publicados nas revistas e nos anais dos ENPEC.

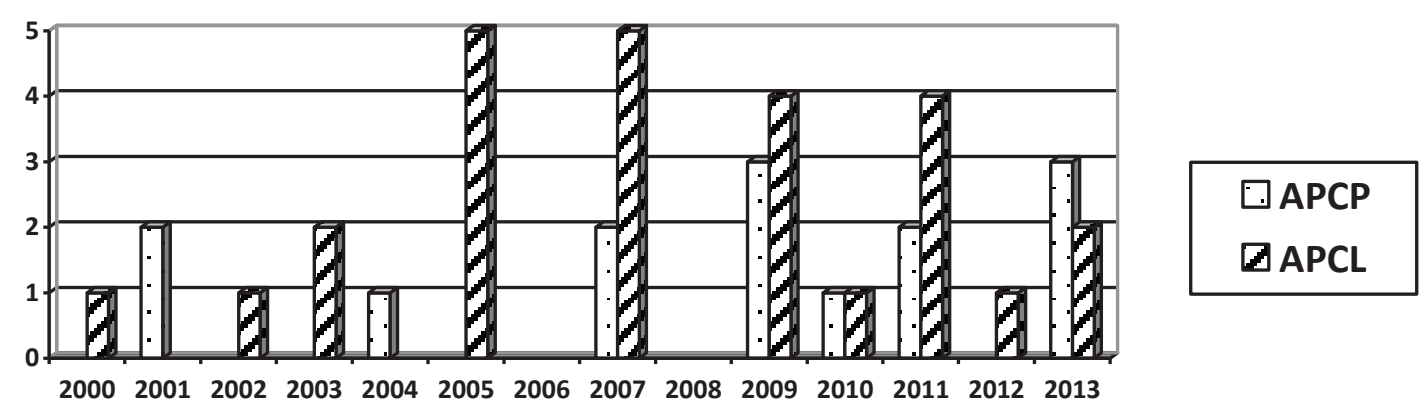

Com relação às revistas analisadas, encontramos dezessete publicações, sendo seis referentes à aprendizagem cooperativa e onze referentes à aprendizagem colaborativa. No período de 2000 a 2009, encontramos sete publicações sobre aprendizagem colaborativa e três publicações sobre aprendizagem cooperativa. Já no período de 2010 a 2013, nas revistas pesquisadas, encontramos quatro publicações sobre aprendizagem colaborativa e três sobre aprendizagem cooperativa.

Comparando-se com o número de artigos publicados internacionalmente, a produção em periódicos no âmbito nacional ainda é incipiente, mas revela que as temáticas vêm sendo explorados de forma constante nos últimos anos, sendo a aprendizagem colaborativa mais explorada na última década, tendência de publicação que não deve mudar na década atual.

No que diz respeito aos trabalhos dos ENPEC, encontramos seis sobre a aprendizagem cooperativa e dezessete sobre aprendizagem colaborativa. A abordagem sobre aprendizagem cooperativa ocorreu pela primeira vez na sexta edição do encontro, com apenas um trabalho. Dessa data em diante, em todas as 
edições, tivemos trabalhos sobre a temática. Os dados também sugerem a atualidade do tema e que suas possibilidades educacionais ainda não foram significativamente exploradas em território nacional.

A abordagem sobre aprendizagem colaborativa ocorreu pela primeira vez na terceira edição do encontro, com um trabalho apresentado. Dessa data em diante foram encontrados trabalhos sobre a temática em todas as demais edições do encontro. Os números sugerem a importância da temática e como seu uso é constante no sistema educacional brasileiro.

A Tabela 7 apresenta a classificação de cada um dos referidos trabalhos de acordo com a instituição de origem, a região brasileira e a área de enfoque, aspectos discutidos nos tópicos seguintes. Os números atribuídos aos trabalhos correspondem à numeração dos trabalhos nas Tabelas 5 e 6 . Doravante, os trabalhos serão referenciados por seus respectivos números.

Tabela 7 - Classificação dos trabalhos de acordo com a instituição de origem.

\begin{tabular}{lccc} 
& & & \\
\hline $\mathbf{N}^{\mathbf{0}}$ & Instituição & Região & Área \\
\hline 1 & USP/UEL & Sudeste/Sul & Física \\
2 & UNESP & Sudeste & Geral \\
3 & UFRPE & Nordeste & Química \\
4 & UEM/UEL & Sul & Ciências \\
5 & USP & Sudeste & Física \\
6 & UFSCar/UFMG & Sudeste & Física \\
7 & UFRPE & Nordeste & Química \\
8 & UFRGS & Sul & Ciências \\
9 & USP & Sudeste & Química \\
10 & USP/UFSCar & Sudeste & Física \\
11 & UFRPE & Nordeste & Química \\
12 & USP & Sudeste & Física \\
13 & USP/IFSC & Sudeste & Geral \\
14 & UFG & Centro-Oeste & Química \\
15 & USP/IQSC & Sudeste & Química \\
16 & UFG & Centro-Oeste & Química \\
17 & USP/IQSC & Sudeste & Química \\
18 & USP/UFSCar & Sudeste & Física \\
19 & UEM/UEL/USP & Sul & Física \\
20 & USP & Sudeste & Geral \\
21 & USP & Sudeste & Geral \\
22 & USP & Sudeste & Física \\
23 & UFMG & Sudeste & Física \\
24 & USP & Sudeste & Física \\
25 & UFU & Sudeste & Biologia \\
26 & UFRPE & Nordeste & Ciências
\end{tabular}


Tabela 7 - Classificação dos trabalhos de acordo com a instituição de origem.

\begin{tabular}{lccc}
\hline$N^{\circ}$ & Instituição & Região & Área \\
\hline 27 & UNESP/UEM & Sudeste/Sul & Biologia \\
28 & USP & Sudeste & Física \\
29 & UFMG & Sudeste & Física \\
30 & IOC/UFF & Sudeste & Biologia \\
31 & UNIDESC/UNB & Centro-Oeste & Química \\
32 & USP & Sudeste & Química \\
33 & USP & Sudeste & Física \\
34 & UFG & Centro-Oeste & Química \\
35 & USP/IQSC & Sudeste & Química \\
36 & UFMG & Sudeste & Física \\
37 & USP/IQSC & Sudeste & Química \\
38 & UNESP & Sudeste & Física \\
39 & UFRPE & Nordeste & Física \\
40 & UCV & ----- & Física \\
\hline
\end{tabular}

\subsubsection{A produção e sua distribuição de acordo com as instituições acadêmicas}

Neste tópico apresentamos uma análise das instituições acadêmicas às quais estão vinculados os autores dos trabalhos analisados. A classificação de cada um dos trabalhos é apresentada na Tabela 7. É necessário destacar que alguns trabalhos foram realizados em parcerias, sendo seus pesquisadores provenientes de duas ou mais instituição.

Figura 5 - Quantidade de trabalhos publicados nas revistas.

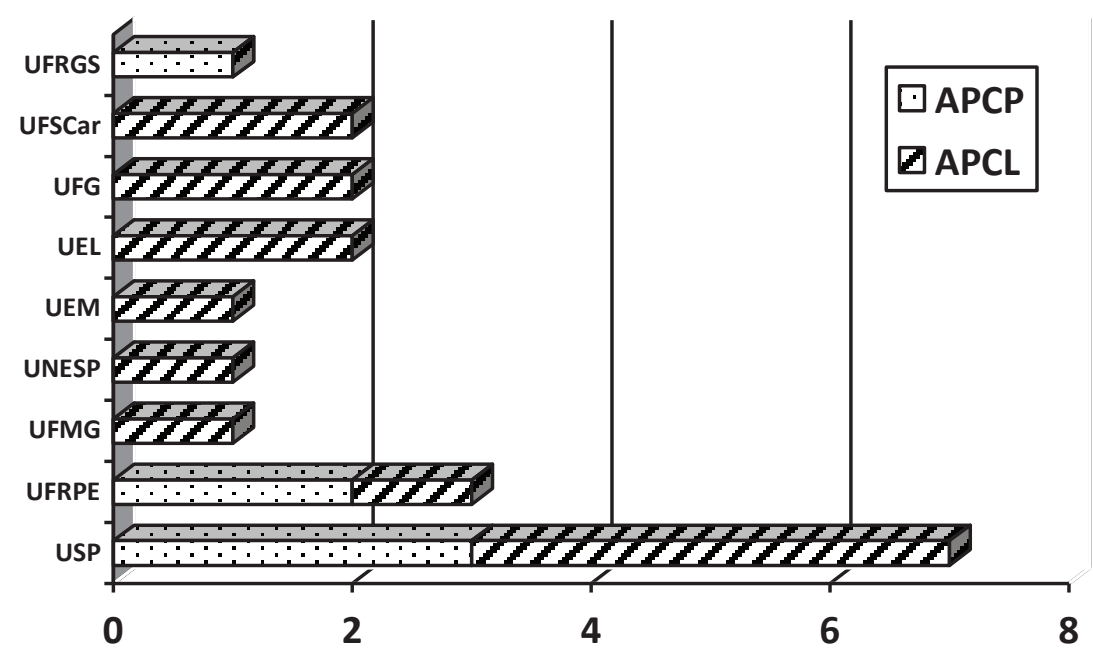


Figura 6 - Quantidade de trabalhos publicados nos anais dos ENPEC.

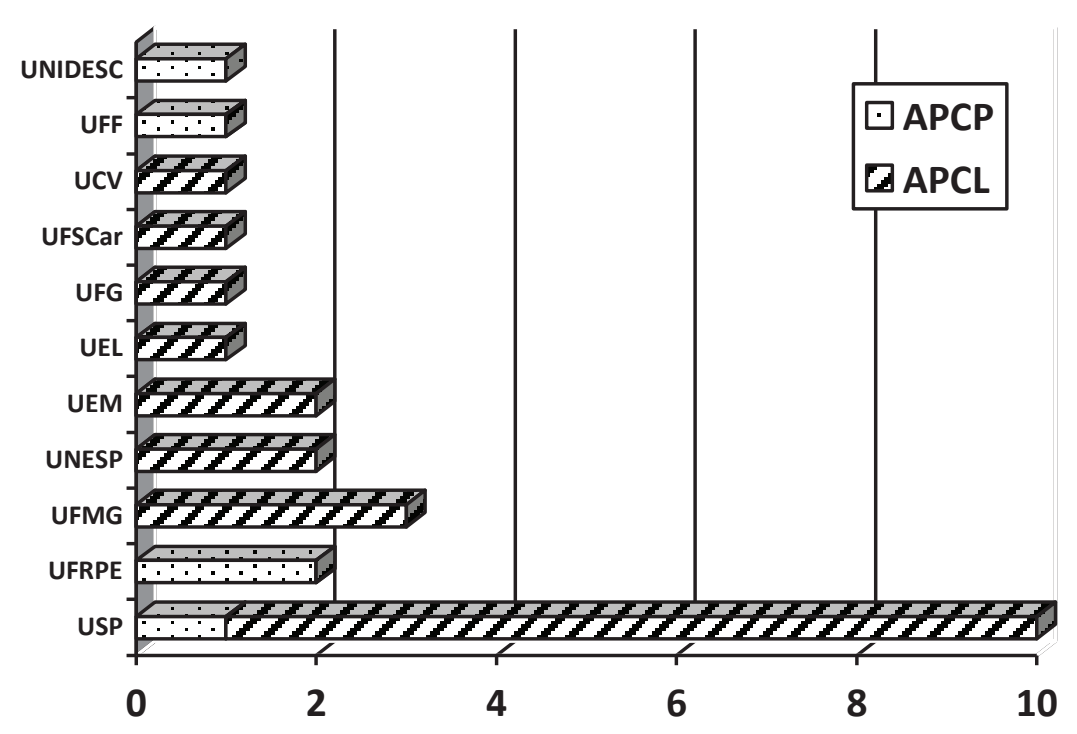

Conforme se verifica na Figura 5, nove instituições foram responsáveis pelos artigos publicados. Ao considerarmos os temas separadamente, oito instituições foram responsáveis pelas publicações sobre aprendizagem colaborativa, enquanto três instituições foram responsáveis pelas seis publicações sobre aprendizagem cooperativa em revistas. É digno de nota que, dos seis artigos localizados sobre aprendizagem cooperativa, cinco são provenientes de apenas duas instituições, sendo elas USP e UFRPE. O mesmo não ocorre com os onze artigos publicados sobre aprendizagem colaborativa, que são provenientes de oito instituições diferentes. A USP foi a instituição que mais publicou trabalhos sobre as duas temáticas, sendo cinco sobre aprendizagem colaborativa e três sobre aprendizagem cooperativa, tendo contribuído de forma mais vigorosa quando nos referimos às temáticas pesquisadas.

Quando analisamos os trabalhos apresentados nos ENPEC, na Figura 6, a tendência verificada nos periódicos se mantém. Onze instituições foram responsáveis pela apresentação de 23 trabalhos. Quando verificamos o número de instituição por temática separadamente, temos sete instituições apresentando dezessete trabalhos sobre aprendizagem colaborativa e cinco instituições apresentando seis trabalhos sobre aprendizagem cooperativa.

Levando em conta apenas os trabalhos apresentados sobre aprendizagem colaborativa, a USP apresentou o maior número de contribuições: nove dos dezessete trabalhos encontrados. Entretanto, quando verificamos apenas os 
trabalhos sobre aprendizagem cooperativa, a UFRPE é a instituição com o maior número de trabalhos publicados.

Cabe ainda destacar a existência de um trabalho sobre o tema na revista Educação e Pesquisa, referente ao ano de 2005. Contudo, sua realização ocorreu na Colômbia, na Universidad Pedagogica Nacional. Logo, não o consideramos representativo para a análise da produção no contexto nacional.

\subsubsection{A produção e sua distribuição de acordo com as regiões brasileiras}

A Tabela 7 apresenta os trabalhos encontrados de acordo com a sua distribuição por região geográfica do Brasil. É importante lembrar que alguns trabalhos foram realizados em parceria, fato que justifica um mesmo trabalho ser classificado para duas regiões diferentes.

Figura 7 - Distribuição dos trabalhos de acordo com as regiões brasileiras.

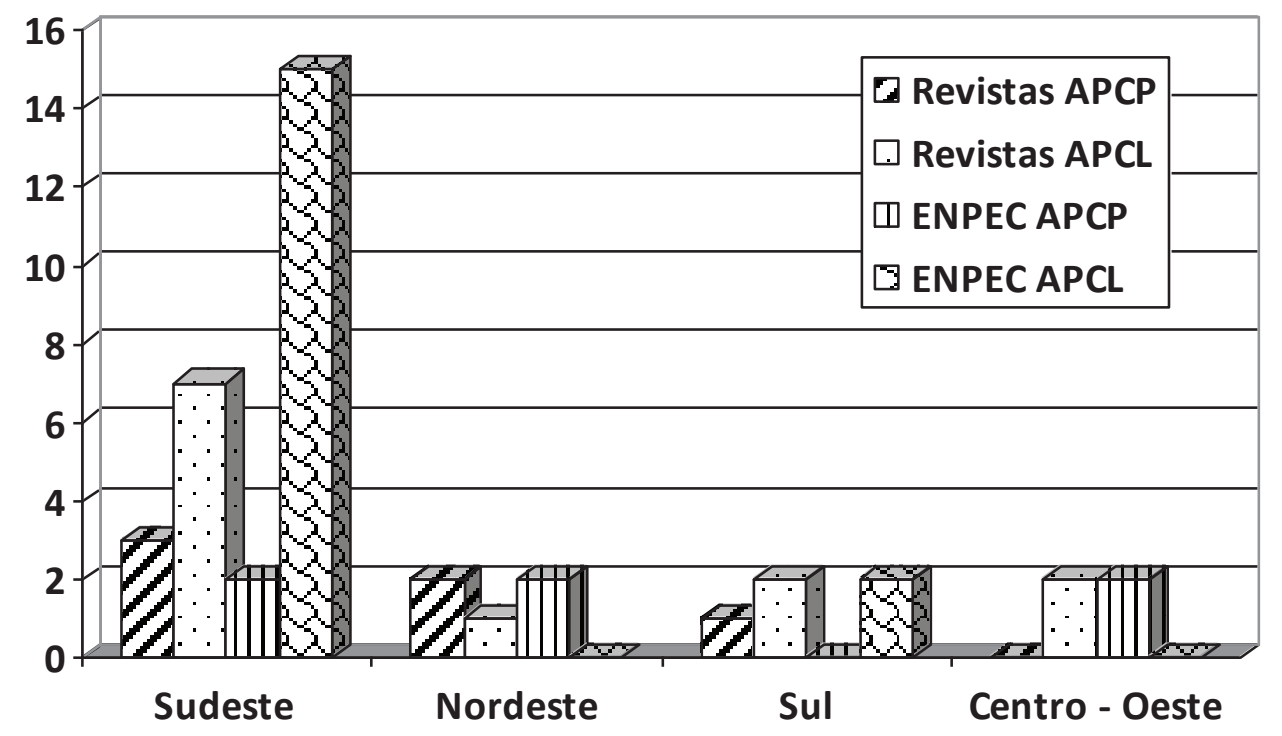

Conforme apresentado na Figura 7, a maioria dos artigos localizados nos periódicos e apresentados nos eventos é proveniente da região Sudeste, sendo dez na forma de artigos e dezessete na forma de trabalhos apresentados em eventos. Conforme reportam Silva e Queiroz (2016), alguns fatores podem contribuir para explicar o maior número de trabalhos encontrados na região: a quantidade de 
Instituições de Ensino Superior de pesquisas de grande tradição em pesquisa como USP, UFMG e UFSCar, bem como a concentração de programas de pós-graduação na região.

As regiões Sul e Nordeste foram as regiões que mais produziram depois da região Sudeste, com cinco trabalhos cada uma. A distribuição entre eventos e periódicos também foi a mesma, sendo três artigos e dois trabalhos apresentados em eventos em cada região. Ressaltando a grande diferença de produção entre as regiões, por fim, encontramos quatro publicações originadas da região CentroOeste, duas na forma de artigo e duas apresentadas no ENPEC.

Verificando as temáticas separadamente, alguns valores se revelam interessantes: na região Sudeste prevalecem os trabalhos direcionados à aprendizagem colaborativa, com 22 trabalhos, contra apenas cinco direcionados para aprendizagem cooperativa; na região Sul, os valores se igualam, com dois trabalhos direcionados para cada tipo de estratégia de aprendizagem; já no Nordeste, os valores invertem-se, com quatro trabalhos direcionados para aprendizagem cooperativa e apenas um direcionado para aprendizagem colaborativa.

Os valores apontados acima mostram que dois grupos de pesquisa (um do Nordeste - Universidade Federal Rural de Pernambuco e um do Sudeste Universidade de São Paulo, campus de São Carlos) são responsáveis pela maior parte do que é publicado referente à temática aprendizagem cooperativa o que indica que, para que o tema se difunda, é necessário que outros grupos de pesquisa desenvolvam a temática nas demais regiões do país.

\subsubsection{A produção e sua distribuição de acordo com a área de pesquisa}

A Figura 8 ilustra o número de trabalhos publicados nas revistas e os trabalhos apresentados nos ENPEC de acordo com a área de pesquisa privilegiada no enfoque dos trabalhos. Na Tabela 7, é possível verificar a classificação de cada um dos trabalhos por área de pesquisa. 
Figura 8 - Distribuição dos trabalhos de acordo com as áreas de pesquisa.

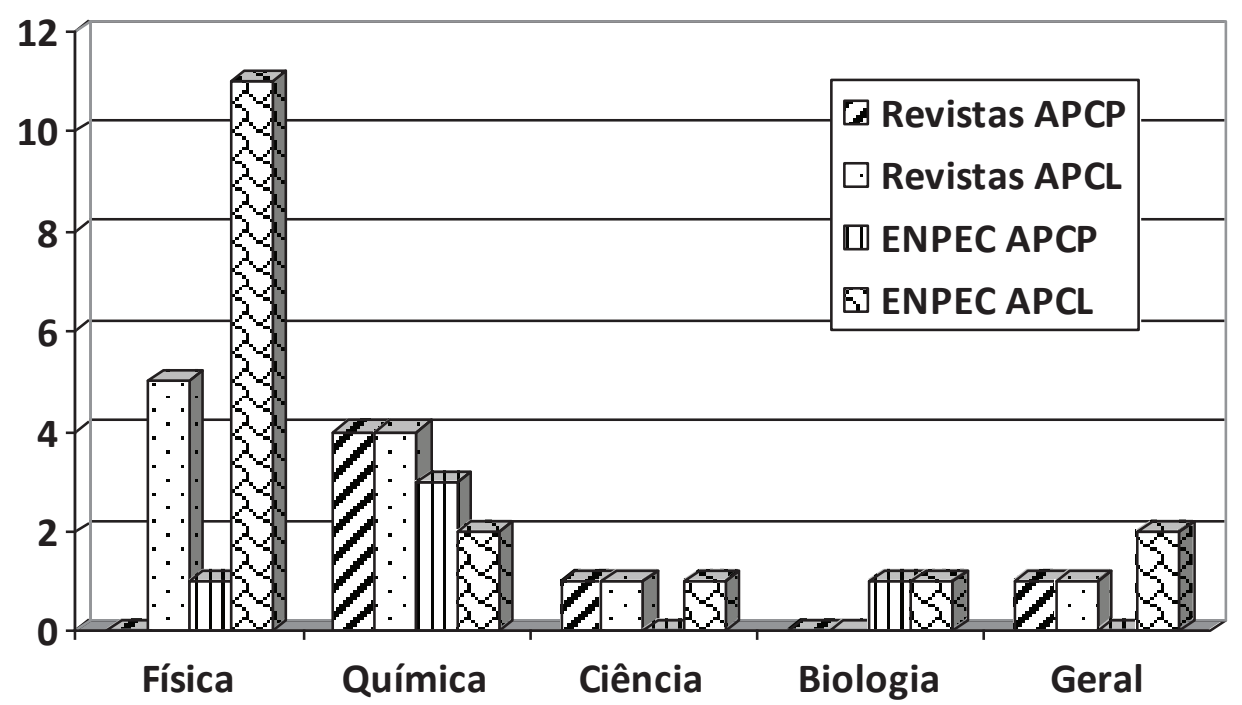

Para a classificação, foram consideradas cinco possíveis áreas: Química, Física, Biologia, Ciências e Geral. Cabe ressaltar que a área de Ciências engloba os trabalhos direcionados para o ensino de Ciências nas séries finais do Ensino Fundamental e aqueles que, mesmo sem direcionamento, discutem temas normalmente voltados para essa área de investigação. Na categoria Geral, foram classificados os trabalhos que não apresentam direcionamento para nenhuma área de forma especifica e aqueles que apresentam levantamento bibliográfico sobre a temática pesquisada.

Ao observarmos a Figura 8, percebemos que a área que mais contribuiu com publicação sobre a temática foi a de Química, com oito artigos publicados, dos quais quatro trataram da aprendizagem cooperativa e quatro da aprendizagem colaborativa. A segunda área com publicações sobre a temática é a de Física, com cinco trabalhos. Entretanto, uma diferença se faz notar quanto à distribuição dos artigos: dos cinco artigos localizados, nenhum trata da aprendizagem cooperativa, todos fazem referência à aprendizagem colaborativa.

Os resultados encontrados para os trabalhos apresentados no ENPEC apresentaram como área com maior contribuição a de Física, com doze publicações, sendo que destas apenas uma tratava sobre aprendizagem cooperativa. Já os resultados encontrados para área de Química, no que concerne aos trabalhos apresentados no ENPEC, apresentaram a mesma tendência dos artigos: dos cinco 
trabalhos apresentados, três tratavam da aprendizagem cooperativa e dois da aprendizagem colaborativa.

Os resultados encontrados para as demais áreas foram bem inferiores aos das áreas de Química e Física, discutidas anteriormente: encontramos quatro publicações classificadas na categoria Geral, três na área de Ciências e duas na área de Biologia. Esses resultados destacam que é na área de Química que ocorrem mais aplicações de novas estratégias de aprendizagem e também é a área em que há o maior número de publicações, mostrando que existe uma lacuna com relação às áreas como Biologia e Ciências que poderiam fomentar iniciativas capazes de explorar melhor as novas estratégias de aprendizagem.

\subsubsection{A produção e sua distribuição de acordo com os níveis de escolaridade}

A identificação do nível de escolaridade foi realizada tendo como base os participantes na pesquisa, os materiais didáticos utilizados, as experiências educacionais descritas na pesquisa e os programas de ensino propostos, fatores sugeridos por Megid Neto (1999). A Tabela 8 apresenta a classificação de cada um dos referidos trabalhos de acordo com o nível educacional e o foco temático, aspectos discutidos nos tópicos seguintes. Os números atribuídos aos trabalhos correspondem à numeração dos trabalhos nas Tabelas 5, 6 e 7.

Tabela 8 - Classificação dos trabalhos de acordo com a área de pesquisa, nível educacional e foco temático, em que $\mathrm{F}=$ Fundamental, $\mathrm{M}=$ Médio, $\mathrm{S}=$ Superior e $\mathrm{G}=$ Geral.

(continua)

\begin{tabular}{|c|c|c|}
\hline $\mathbf{N}^{\circ}$ & Nível & Foco temático/Abordagem \\
\hline 1 & S & Aprendizagem colaborativa em parceria com outras estratégias \\
\hline 2 & G & Aprendizagem colaborativa em perspectiva teórica \\
\hline 3 & $\mathrm{~F}$ e $\mathrm{S}$ & Aprendizagem cooperativa e suas possibilidades \\
\hline 4 & $\mathrm{~F}$ & Aprendizagem colaborativa e suas possibilidades \\
\hline 5 & M & Aprendizagem colaborativa e suas possibilidades \\
\hline 6 & M & Aprendizagem colaborativa e suas possibilidades \\
\hline 7 & M & Aprendizagem colaborativa e suas possibilidades \\
\hline 8 & $\mathrm{~F}$ & Aprendizagem cooperativa e suas possibilidades \\
\hline 9 & M & Aprendizagem colaborativa em parceria com outras estratégias \\
\hline 10 & M & Aprendizagem colaborativa e suas possibilidades \\
\hline 11 & M & Aprendizagem cooperativa e suas estratégias específicas \\
\hline 12 & M & Aprendizagem colaborativa em parceria com outras estratégias \\
\hline
\end{tabular}


Tabela 8 - Classificação dos trabalhos de acordo com a área de pesquisa, nível educacional e foco temático, em que $\mathrm{F}=$ Fundamental, $\mathrm{M}=$ Médio, $\mathrm{S}=$ Superior e $\mathrm{G}=$ Geral.

(conclusão)

\begin{tabular}{ccl}
\hline$N^{\circ}$ & Nível & Foco temático/Abordagem \\
\hline 13 & M & Aprendizagem cooperativa e suas estratégias específicas \\
14 & S & Aprendizagem colaborativa e suas possibilidades \\
15 & M & Aprendizagem cooperativa e suas estratégias específicas \\
16 & M & Aprendizagem colaborativa e suas possibilidades \\
17 & M & Aprendizagem cooperativa e suas estratégias específicas \\
18 & M & Aprendizagem colaborativa e suas possibilidades \\
19 & M & Aprendizagem colaborativa e suas possibilidades \\
20 & G & Aprendizagem colaborativa em perspectiva teórica \\
21 & G & Aprendizagem colaborativa e suas possibilidades \\
22 & M & Aprendizagem colaborativa e suas possibilidades \\
23 & M & Aprendizagem colaborativa e suas possibilidades \\
24 & M & Aprendizagem colaborativa em parceria com outras estratégias \\
25 & S & Aprendizagem colaborativa e suas possibilidades \\
26 & F & Aprendizagem cooperativa e suas estratégias específicas \\
27 & S & Aprendizagem colaborativa em parceria com outras estratégias \\
28 & S & Aprendizagem colaborativa e suas possibilidades \\
29 & M & Aprendizagem colaborativa e suas possibilidades \\
30 & M e S & Aprendizagem cooperativa e suas possibilidades \\
31 & M & Aprendizagem cooperativa e suas possibilidades \\
32 & M e S & Aprendizagem colaborativa e suas possibilidades \\
33 & M & Aprendizagem colaborativa e suas possibilidades \\
34 & M & Aprendizagem colaborativa e suas possibilidades \\
35 & G & Aprendizagem cooperativa em perspectiva teórica \\
36 & M & Aprendizagem colaborativa e suas possibilidades \\
37 & S & Aprendizagem cooperativa em parceria com outras estratégias \\
38 & M & Aprendizagem colaborativa e suas possibilidades \\
39 & S & Aprendizagem cooperativa em parceria com outras estratégias \\
40 & G & Aprendizagem colaborativa em perspectiva teórica \\
\hline & &
\end{tabular}

A Figura 9 ilustra que o nível de escolaridade que mais se destacou dentro da nossa pesquisa foi o Ensino Médio, tanto nos artigos publicados, quanto nos trabalhos apresentados nos ENPEC, com 22 trabalhos privilegiando esse nível. A superioridade do nível em questão também se mantém quando verificamos as temáticas separadamente, com quinze trabalhos versando sobre aprendizagem colaborativa e sete trabalhos versando sobre aprendizagem cooperativa, de modo que podemos apontar esse nível como o principal na divulgação e uso das estratégias em questão. 
Figura 9 - Distribuição dos trabalhos de acordo com o nível de escolaridade.

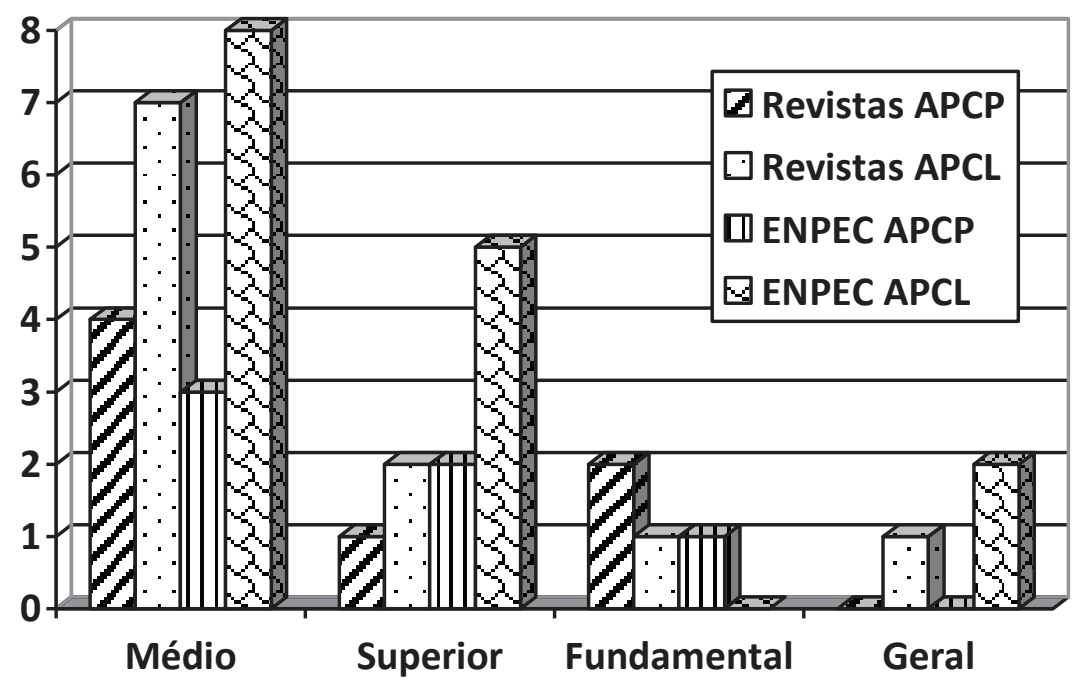

O segundo nível com maior número de trabalhos foi o Ensino Superior, com dez trabalhos, sendo sete sobre aprendizagem colaborativa e três sobre aprendizagem cooperativa. Nesse nível existem muitas perspectivas que permitem o trabalho com as estratégias de aprendizagem. Cabe ressaltar ainda que, no Ensino Fundamental, encontramos quatro trabalhos, dos quais três são sobre aprendizagem cooperativa.

Portanto, pode-se afirmar que, diferentemente das tendências observadas nos trabalhos internacionais, que privilegiavam o Ensino Superior, no Brasil, a maioria dos trabalhos é voltada para o Ensino Médio, indicando uma lacuna na área de pesquisa e a necessidade de fomento a iniciativas que buscam desenvolver investigações sobre a temática no Ensino Superior.

\subsubsection{A produção e sua distribuição de acordo com o foco temático}

A análise dos trabalhos nacionais foi realizada adotando-se o mesmo procedimento desenvolvido para os trabalhos internacionais, com os mesmos focos temáticos descritos anteriormente. 


\section{Aprendizagem cooperativa e suas possibilidades}

Dentre os doze trabalhos nacionais sobre aprendizagem cooperativa, quatro $(3,8,30$ e 31) tratam especificamente de experiências voltadas à análise das possibilidades da aprendizagem cooperativa.

O trabalho 3 aponta a aprendizagem cooperativa como uma abordagem que favorece o alcance de resultados acadêmicos melhores por parte dos alunos e ajuda no desenvolvimento de habilidades sociais, preparando alunos mais aptos para os trabalhos em equipes e mais comprometidos com valores sociais. Entretanto, os autores ressaltam a importância na escolha a ser feita pelo professor com relação à estratégia cooperativa a ser empregada, já que o bom funcionamento da atividade depende fundamentalmente da adequação da estratégia à aula a ser ministrada.

No trabalho 8 os autores verificaram a potencialidade da aprendizagem cooperativa no auxílio à formação de um aluno preparado para as necessidades atuais, que exigem o domínio da sua área. Como resultado, os autores indicam que um melhor desempenho acadêmico dos alunos relacionou-se diretamente à interação proporcionada pela atividade, que criou uma interdependência positiva, fazendo com que trabalhassem pensando no grupo como um todo, melhorando sua interação durante as atividades e promovendo uma aprendizagem mais rica. Salientam ainda que o grupo não garante o resultado positivo por si só, sendo necessária uma estrutura que conduza à interdependência positiva.

O trabalho de número 30 compara atividades cooperativas com competitivas, na tentativa de encontrar um meio que fortaleça a aprendizagem sem estimular em demasia a competição. Para tanto, os autores sugerem jogos cooperativos, nos quais os alunos jogam um "com o outro" e não um "contra o outro". Como resultado, os autores classificam a atividade cooperativa como válida, com alunos que apresentam resultados superiores aos participantes de atividades puramente competitivas, e esperam que os resultados reportados contribuam para destacar o seu potencial no ensino de Biologia, tanto no Ensino Médio quanto no Ensino Superior.

No trabalho 31 os autores apresentam a aprendizagem cooperativa como uma alternativa para melhorar o desempenho dos alunos do Ensino Médio de Química. Ainda com resultados parciais, estes tentam verificar as potencialidades e 
os desafios na utilização dessa estratégia. Primeiramente, os autores indicam as dificuldades em colocá-la em prática, o que exige muito mais do que o domínio de conteúdo e depende de todos os participantes do processo. Por fim, apontam como maior ganho as relações sociais e a motivação dos alunos.

\section{Aprendizagem colaborativa e suas possibilidades}

Dentre os 28 trabalhos nacionais sobre aprendizagem colaborativa, vinte (4, $5,6,7,10,14,16,18,19,21,22,23,25,28,29,32,33,34,36$ e 38) tratam de experiências voltadas à análise das possibilidades da aprendizagem colaborativa.

Os autores dos trabalhos 4, 5, 6, 10, 18, 19, 21, 22, 23, 28 e 32 chamam a atenção para o papel do professor nas atividades sociais que visam à construção do conhecimento científico, apontando-o como fundamental para que o grupo tenha um resultado positivo. Destacam também que o professor deve abandonar a postura passiva e participar de forma ativa como um condutor da atividade, entendendo o processo e interferindo na hora certa para obter o melhor resultado dos alunos. Chama atenção às conclusões alcançadas pelos autores dos trabalhos 6, 29, 36 e 38 que afirmam que mesmo um grupo formado por alunos considerados hábeis pode findar em resultados negativos se não tiver a orientação do professor, de forma que o sucesso do grupo depende em boa parte de fatores externos.

Os autores dos trabalhos também atentam para o fato de que o professor deve conhecer o grupo de trabalho, identificando possíveis papéis gerados pela atividade em grupo como: líder, porta voz, entre outros, sabendo identificar e conduzir a atividade de forma que todos os alunos sejam capazes de usar esses papéis em favor da atividade. Se possível, o professor deve conduzir os alunos a desenvolver o hábito de trocar de papel durante a atividade. Corroboram com tais dizeres os autores do trabalho 5 , que concluem ser fundamental para o professor conhecer o processo de aprendizagem dos alunos nos grupos, para poder conduzir as atividades e modificar suas intervenções, tendo maior chance, assim, de obter sucesso.

De forma complementar, existem artigos, como o de número 19, que indicam a necessidade de se refletir sobre como o professor interage com o grupo, assim determinando quais são os discursos dominantes empregados por ele em sala de aula, reconhecendo quais discursos aproximam e quais afastam os alunos, o que 
deve ser uma análise pessoal, mas que deveria fazer parte da formação do professor de Ciências.

Os trabalhos de números 21, 28 e 32 apresentaram indícios de que o trabalho em pequenos grupos pode também ajudar na formação continuada do professor, por exigir diversas características que se fazem necessárias também em sala de aula, dentre as quais a narrativa e a negociação. Essas características podem ser adquiridas no trabalho com alunos em grupos, mas também na participação de grupos formados por docentes, como o caso apresentado no trabalho 32.

O trabalho 14 direciona sua investigação na busca de determinar as potencialidades da aprendizagem colaborativa no desenvolvimento de habilidades sociais. Para tanto, analisou grupos de aprendizagem formados por alunos de diferentes turmas, permitindo um ambiente propício para a troca de experiência, de forma a facilitar o percurso acadêmico dos alunos calouros. Como resultado, os próprios alunos avaliaram a atividade de forma positiva.

O trabalho 25 verifica a estrutura do grupo e sua influência dentro da atividade, sugerindo que a simples formação do grupo por afinidade pode levar à exclusão social e a ações individualizadas. Com o objetivo de modificar essa situação, sugere a utilização de um painel integrado que, por meio de características dos alunos, gera modificação na estrutura dos grupos. Como resultado, foram coletadas as impressões dos alunos, que se mostraram favoráveis à atividade, ressaltando, entretanto, a preferência pela formação do grupo por afinidade. O uso do painel foi considerado positivo pelos autores, já que permitiu a interação e boa execução da atividade proposta.

Os autores do trabalho 34 direcionam a sua atenção para a função do aluno no processo de ensino-aprendizagem enfatizando que a aprendizagem ocorrerá de forma plena se o aluno for o principal responsável pelo seu conhecimento, de forma que a aprendizagem colaborativa, se bem direcionada, pode ser um caminho para o alcance de uma aprendizagem mais centrada no aluno e não no professor. 


\section{Aprendizagem cooperativa e suas estratégias especificas}

Os trabalhos $11,13,15,17$ e 26 foram classificados neste foco temático, sendo o método jigsaw objeto central de todos os textos analisados. Dentre eles, apenas o trabalho 11 , além de tratar da estratégia jigsaw, também faz referência à estratégia TGT.

Nos trabalhos 11,15 e 17 os autores apresentam o método jigsaw como uma possibilidade para desenvolver habilidades de comunicação e aprendizagem dos conceitos de Ciências, tendo como característica em comum o desenvolvimento de habilidades sociais. O trabalho 11 verificou a influência de dois métodos cooperativos combinados (jigsaw e TGT). O segundo método se baseia em torneios em que os alunos disputam em grupos em busca de uma premiação. Esse é considerado um método motivador, pois direciona os alunos a participarem de forma ativa em busca do prêmio.

Nos trabalhos 13, 15, 17 e 26 o jigsaw é aplicado em diferentes contextos e diferentes disciplinas, abarcando conteúdos de Química Medicinal, Cinética e Nanotecnologia, o que resultou em um trabalho mais ativo dos alunos em todas as disciplinas testadas. Verificou-se, ainda, como ganho, habilidades sociais e de assimilação do conteúdo. Outro fator a ser considerado é a versatilidade da estratégia em questão, pois nos quatro artigos mencionados ela foi trabalhada em diferentes níveis de ensino, apresentando resultados satisfatórios em todos.

\section{Aprendizagem colaborativa e suas estratégias especificas}

Para este foco não foi encontrado nenhum trabalho em âmbito nacional, diferentemente do que acontece em ambiente internacional, onde estratégias colaborativas, como PLTL têm mostrado resultados positivos no ensino de Ciências. Nessa perspectiva, existe uma limitação no uso dessa estratégia em âmbito nacional quando comparado com o âmbito internacional e também uma possibilidade de pesquisa na área de Ciências a ser explorada. 


\section{Aprendizagem cooperativa em parceria com outras estratégias}

Os trabalhos 37 e 39 foram classificados neste foco temático. No trabalho 37 são discutidos os benefícios decorrentes do uso de recursos computacionais associados à estratégia cooperativa jigsaw no Ensino Superior de Química. Com o uso das TIC, os autores analisaram as interações on-line estabelecidas entre alunos de graduação em Química em fórum de discussão, verificando a dinâmica de participação e as interações entre os alunos e entre os alunos e o professor. Indicaram em seus resultados que a natureza da atividade a ser realizada é um dos principais fatores para determinar o tipo de participação e a interação que os alunos terão, não sendo indicado o uso de questões fechadas ou roteiros se o objetivo for a promoção da interação e troca de conhecimento. Por fim, os autores sugerem que os benefícios do uso das TIC estão diretamente relacionados com a frequência de uso.

No trabalho 39 os autores descrevem uma proposta metodológica de estágio supervisionado, na modalidade a distância, associado a atividades cooperativas, com o objetivo de contribuir para a formação de professores capazes de desenvolver ações, intervenções, habilidades e competências no exercício da sua profissão. A pesquisa apresenta em seus resultados parciais que a aprendizagem cooperativa possibilitou reflexões e avaliações sobre a prática. Além disso, espera-se que ela, aliada às TIC, possibilite que docentes que estejam distantes geograficamente possam trabalhar de forma cooperativa, trazendo ganho para todos os que participam do processo.

\section{Aprendizagem colaborativa em parceria com outras estratégias}

Os trabalhos 9, 12, 24 e 27 foram classificados neste foco temático. No trabalho 12 são discutidos os benefícios da utilização da aprendizagem colaborativa durante atividades investigativas com experimentação para o ensino de Física. Como maior benefício, os autores apontam a interação entre os alunos e o fomento a questionamentos investigativos. A interação só ocorreu de forma efetiva graças à igualdade que a atividade em grupo permite. 
Os trabalhos 9, 24 e 27 relacionam o trabalho colaborativo com o uso de computadores em perspectivas diferentes. No trabalho 9 encontramos a aprendizagem colaborativa associada a um laboratório didático virtual de Química. Nele os alunos desenvolvem simulações que ajudam na assimilação dos conceitos. Os autores apontam como positivo o fato de a atividade tornar o conhecimento mais próximo do cotidiano do aluno, além do desenvolvimento de habilidades sociais.

O trabalho 24 apresenta um programa de computador que pode ser utilizado associado à aprendizagem colaborativa, gerando diversas possibilidades de interação entre os alunos.

No trabalho 27 os autores verificam a possibilidade do uso de computadores na formação de professores em uma perspectiva colaborativa. A intenção é levar para sua formação reflexões sobre o processo de ensino-aprendizagem.

\section{Aprendizagem cooperativa apresentada em perspectiva teórica}

Apenas um trabalho foi classificado neste foco temático. O pequeno número deu-se, entre outros motivos, pelo fato de a temática ainda ser pouco explorada em âmbito nacional. O trabalho 35 apresentou uma discussão sobre a produção acadêmica brasileira e internacional a respeito da aprendizagem cooperativa no Ensino de Ciências até 2010. Para tanto, foram investigados trabalhos apresentados nos ENPEC e em revistas nacionais e internacionais. Com os resultados, foram feitas considerações quanto à abrangência dos trabalhos com relação aos seguintes aspectos: ano de publicação, área de conhecimento, nível de escolaridade e foco temático.

Os resultados mostraram que os trabalhos encontrados em âmbito nacional eram ainda escassos e concentrados no Ensino Fundamental e Médio, diferentemente do observado internacionalmente, em que as pesquisas se concentram no Ensino Superior. A Química apresentou o maior volume de publicações nos dois contextos. Cabe ressaltar que os autores apontaram a estratégia como capaz de levar os alunos a melhor desempenho acadêmico. 


\section{Aprendizagem colaborativa apresentada em perspectiva teórica}

Os trabalhos 2, 20 e 40 foram classificados neste foco temático. O artigo 2 propõe um debate de questões relativas à atividade de grupo e a educação científica em uma abordagem sócio-histórica. Para tanto, os autores usam como base as obras de Vigotski e Leontiev, verificando o papel da colaboração no alcance de novos níveis de desenvolvimento. Dentre as questões suscitadas estão: "É possível estabelecer aproximações entre educação cientifica e atividade grupal? Em que medida a atividade grupal na escola pode contribuir para o desenvolvimento do pensamento científico?". Por fim, os autores se mostraram confiantes no uso das atividades colaborativas, embora tenham afirmado que a atividade em grupo só se tornará efetiva se o professor for capaz de organizar o trabalho e identificar as potencialidades dos alunos, não exigindo deles uma cooperação que eles não estejam preparados para oferecer.

O trabalho 20 apresenta uma análise de alguns exemplos de atividades colaborativas com o objetivo de mostrar que o referencial do psicanalista René Kaës pode servir como base para a compreensão das relações ocorridas durante as atividades, em três diferentes dimensões.

O trabalho 40, apesar de apresentado no ENPEC, não faz referência à pesquisa realizada em âmbito nacional. Assim, sua análise não teria contribuições para o entendimento do contexto nacional.

Diante do exposto, percebe-se que os trabalhos encontrados em âmbito internacional para aprendizagem cooperativa estão concentrados nos níveis de escolaridade Ensino Superior. Diferentemente, para aprendizagem colaborativa, os trabalhos concentram-se nos níveis Médio e Superior. Já com relação à área de ensino, a Química apresenta o menor volume de pesquisa em aprendizagem colaborativa. Diferentemente, para aprendizagem cooperativa, a área de Química está entre as duas com maior número de trabalhos. Destaca-se, ainda, o notório crescimento na produção de trabalho para as duas estratégias nas últimas décadas.

Em âmbito nacional, o número de trabalhos sugere que nossa produção sobre as temáticas ainda é incipiente, mas aponta um interesse crescente nos últimos anos, sendo a aprendizagem colaborativa mais explorada do que a aprendizagem cooperativa. Com relação ao nível de ensino, temos o Ensino Médio como o maior 
privilegiado em ambas as estratégias. No que se referente à área de ensino, a Física apresenta o maior volume de pesquisas em aprendizagem colaborativa. Já a Química é a segunda maior área em número de trabalhos e também apresenta um equilíbrio no número de publicações, tanto para aprendizagem cooperativa, quanto para a aprendizagem colaborativa. Chama a atenção o fato de o Sudeste do Brasil ser a região que domina a produção de trabalhos para as duas estratégias. Entretanto, o número de trabalhos sugere a atualidade do tema e indica que suas possibilidades educacionais ainda não foram significativamente exploradas nas diferentes áreas e tampouco nos diferentes níveis, denotando o potencial de pesquisa em contexto nacional. 


\section{OBJETIVOS}

Neste trabalho tratamos de aspectos relacionados à dinâmica das interações discursivas estabelecidas em pequenos grupos no Ensino Superior de Química, cuja organização se pauta nos preceitos da aprendizagem cooperativa (formato jigsaw) e nos preceitos da aprendizagem colaborativa (formato PLTL). O trabalho foi realizado em diferentes disciplinas oferecidas a alunos no Curso de Bacharelado em Química do Instituto de Química de São Carlos, da Universidade de São Paulo (IQSC/USP), com os seguintes objetivos:

- Investigar a dinâmica das interações discursivas estabelecidas entre os alunos, dentro dos seus respectivos grupos cooperativos e colaborativos, a partir da análise das seguintes dimensões: processamento cognitivo, processamento social e funções da fala (KUMPULAINEN; MUTANEN, 1999). Em particular, investigar a influência do tipo de conteúdo e da estrutura dos grupos na forma como as interações discursivas dos alunos são estabelecidas.

- Apontar potencialidades das atividades em pequenos grupos cooperativos e colaborativos, a partir da investigação da dinâmica das interações discursivas estabelecidas entre os alunos com relação às atividades.

Na medida em que os objetivos acima citados foram alcançados, buscamos respostas para as seguintes questões de pesquisas: (1) De que forma a natureza específica da disciplina pode influenciar na dinâmica das interações discursivas em um grupo cooperativo jigsaw? (2) De que forma a natureza especifica da disciplina pode influenciar na dinâmica das interações discursivas em um grupo colaborativo PLTL? (3) De que forma o grau de estrutura da atividade de pequeno grupo pode interferir na dinâmica das interações discursivas em uma mesma disciplina? As respostas às perguntas permitirão a tessitura de considerações quanto à viabilidade da utilização de atividades realizadas em pequenos grupos em diferentes disciplinas do Ensino Superior de Química. 


\section{REFERENCIAIS TEÓRICOS}

Para que as atividades didáticas descritas neste trabalho se concretizassem foi necessário, inicialmente, que determinássemos os métodos de aprendizagem cooperativa e colaborativa que iríamos adotar dentre aqueles relatados na literatura (COCHITO, 2004; BARBOSA; JÓFILI, 2004; DOYMUS, 2007; GAFNEY; VARMANELSON, 2008). A escolha dos métodos jigsaw e PLTL deveu-se ao fato de a sua aplicação ser apontada como capaz de desenvolver uma postura mais ativa dos alunos, assim como agregar ganhos em habilidades interpessoais (JOHNSON; JOHNSON; HOLUBEC, 1999; COCHITO, 2004; BARBOSA; JÓFILI, 2004; GAFNEY; VARMA-NELSON, 2008). Para investigar a dinâmica das interações estabelecidas entre os alunos, dentro dos seus respectivos grupos, nos baseamos no Modelo Analítico proposto por Kumpulainen e Mutanen (1999).

Os referencias teóricos acima mencionados encontram-se sucintamente descritos a seguir.

\subsection{Método Cooperativo Jigsaw}

Desenvolvido por Aronson (1978), o método jigsaw pode ser definido como um conjunto de procedimentos que se adéquam ao desenvolvimento de competências cognitivas de nível superior, preservando os principais fundamentos da aprendizagem cooperativa defendidos pelos irmãos Johnson (JOHNSON; JOHNSON; HOLUBEC, 1999). Testado pela primeira vez nos Estados Unidos (Austin/Texas), no ano de 1971, em uma época marcada por lutas civis, mostrou-se uma ferramenta eficiente para amenizar conflitos de caráter racial entre jovens brancos, negros e hispânicos, que em virtude das atividades se encontraram pela primeira vez juntos em uma sala de aula.

No formato jigsaw, os alunos trabalham em grupos que seguem os preceitos da aprendizagem cooperativa, de forma que o trabalho que cada aluno realiza tornase essencial para que o resultado final do grupo seja satisfatório. Esse método lembra um quebra-cabeça, que somente está concluído quando todas as peças estão encaixadas. Daí a origem do nome jigsaw. A Figura 10 ilustra um esquema da formação dos grupos conforme esse método. 
Figura 10 - Esquema de formação de pequenos grupos de discussão pelo método jigsaw adaptado de Barbosa e Jófili (2004). Existe apenas um grupo de origem, que é formado por alunos $A, B, C$ e $D$ (grupo de base). Existem quatro subgrupos, que são formados por alunos $A$, $B, C$ ou $D$ (grupos de especialistas). As setas indicam a movimentação dos alunos nos grupos: todos são provenientes do grupo de origem e a ele retornam, na etapa final da atividade.

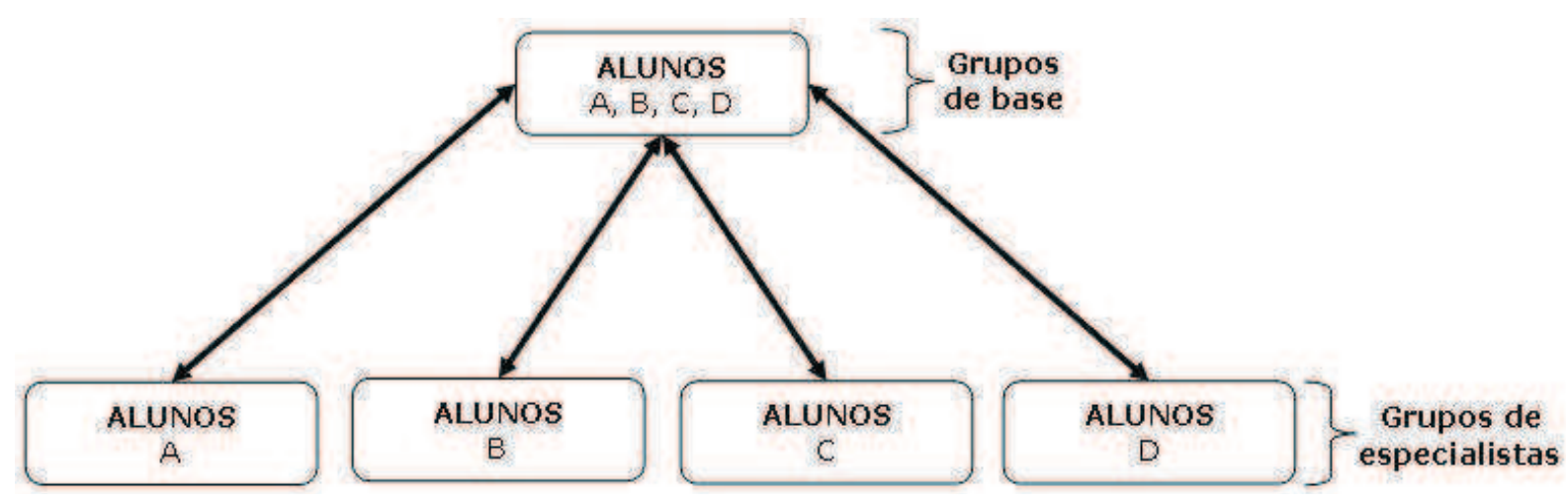

A primeira fase da atividade consiste na divisão dos estudantes em grupos de base heterogêneos, com o objetivo de evitar o isolamento e a discriminação na formação dos grupos, dando a chance aos alunos com mais dificuldade de receberem suporte dos alunos mais adiantados. Ao mesmo tempo, a heterogenia dos alunos permite um conjunto de interações que podem gerar vantagens cognitivas para eles. Cada membro do grupo é designado a estudar apenas uma parte do material acadêmico, que é previamente dividido em pequenas partes.

$\mathrm{Na}$ segunda fase são formados novos grupos baseados nas partes do material didático que foi dividido na fase anterior. Dessa forma, os alunos designados a estudarem a mesma parte do material didático reúnem-se em um mesmo grupo e discutem apenas a parte designada, formando grupos denominados de especialistas.

Na terceira fase, munidos de uma visão mais aprofundada da sua parte do material didático, decorrente das atividades nos grupos de especialistas, cada aluno volta ao seu grupo de base original e compartilha o que aprendeu do seu material com os outros membros do seu grupo de base.

Cabe destacar que, no escopo do presente trabalho, entendemos o método jigsaw como uma atividade cooperativa formal (JOHNSON; JOHNSON; HOLUBEC, 1999). Assim, procuramos tornar o trabalho cooperativo funcional e produtivo, garantindo que as seguintes condições permeassem o processo de ensino- 
aprendizagem: interdependência positiva; responsabilidade individual; interação face-a-face.

A interdependência positiva foi estimulada a partir do estabelecimento de:

- Interdependência positiva de recompensa: caso participassem de todas as atividades, os alunos seriam agraciados com um ponto a mais na média, desde que a média exigida para aprovação na disciplina já tivesse sido previamente alcançada;

- Interdependência positiva de recursos: cada um dos alunos do grupo detinha a posse de apenas parte do material didático necessário para a realização da tarefa solicitada.

A responsabilidade individual foi estimulada por meio da formação de grupos pequenos (máximo de cinco alunos) e da realização de avaliações individuais sobre o conteúdo da disciplina estudado no jigsaw, enquanto a interação face-a-face entre os alunos ocorreu pelo menos uma vez por semana, em horário extraclasse em grupo ou em classe em grupo.

\subsection{Método Colaborativo PLTL}

As origens do PLTL, um método colaborativo de aprendizagem idealizado para o ensino de disciplinas de Ciências, Engenharia e Matemática na graduação, remontam ao início dos anos noventa, quando David Gosser, professor do City College of New York, recebeu os primeiros subsídios financeiros por parte da National Science Foundation (NSF) para o seu desenvolvimento. Os subsídios foram mantidos até 2003, de modo que o método foi amplamente testado, evidenciando suas limitações e possibilidades. Participaram dessa empreitada escolas de nível superior sediadas em Nova York e outras espalhadas pelo território americano. $O$ apoio financeiro se destinou tanto ao seu desenvolvimento quanto à sua divulgação e adaptação a outros contextos diferenciados do inicial: disciplina de Química Geral (GAFNEY; VARMA-NELSON, 2008).

O PLTL tem a liderança estudantil como um elemento unificador chave, que catalisa o envolvimento dos alunos no aprendizado da Ciência e lhes proporciona oportunidades de desenvolvimento intelectual e pessoal, bem como uma reestruturação de seu conhecimento de conteúdo. Essa abordagem preserva a aula expositiva e traz em seu bojo uma nova estrutura, definida como oficina, na qual os 
alunos interagem para resolver problemas sob a orientação de um líder (peer leader), um estudante que cumpriu os créditos referentes à disciplina em foco com ótimo rendimento. Ademais, tais sujeitos são selecionados de acordo com as habilidades de comunicação e liderança que apresentam, assim como o desejo de contribuir para a aprendizagem de seus pares.

Cada oficina PLTL gira em torno da resolução de problemas e da realização de atividades cuidadosamente construídas. Tarefas ministradas pelo docente para execução em casa, por exemplo, são selecionadas para estudo nas oficinas, tendo em vista o domínio de conteúdo. Segundo Gafney e Varma-Nelson (2008), para que as oficinas ocorram com sucesso os seguintes componentes são desejáveis:

- Envolvimento do docente: o docente da disciplina precisa estar envolvido na construção e realização das oficinas. Ou seja, elas não podem ser oferecidas de forma suplementar ou à parte do curso em questão. Devem ser planejadas e implementadas pelo docente, que pode participar da seleção e do treinamento dos líderes e do desenvolvimento de materiais didáticos nelas empregados;

- Integração das oficinas ao curso: as oficinas são uma característica essencial do curso e não opcional. Para que a oficina seja eficaz é importante que os estudantes a vejam como parte do curso, tão importante quanto as aulas expositivas, tarefas de casa ou testes. Para a maioria dos instrutores originais isso significava que as oficinas deveriam ser obrigatórias. Com o passar do tempo e difusão do programa, por uma razão ou outra, muitos instrutores têm feito oficinas de forma opcional para os alunos, mas como uma decisão tomada no início do curso. É essencial, no entanto, que os participantes das oficinas, mesmo que opcionais, vejam-nas como altamente significativas para a aprendizagem;

- Seleção do líder e treinamento: os líderes das oficinas devem ser selecionados, treinados e supervisionados, adquirindo conhecimento sobre a disciplina e sobre técnicas de aprendizagens em pequenos grupos;

- Utilização de materiais apropriados: os materiais didáticos empregados nas oficinas devem ser desafiadores (com grau crescente de dificuldade na resolução das atividades), destinados a estimular a aprendizagem ativa e adequados para o trabalho em grupo. O desenvolvimento de materiais 
apropriados é fundamental para o sucesso das oficinas. Usualmente, o material encontrado em livros ou apostilas é adaptado para o trabalho em grupo, já que sua confecção é feita voltada para o trabalho individual;

- Organização adequada do grupo: as indicações presentes na literatura, incluindo o tamanho do grupo, espaço, tempo, nível de ruído etc, são relevantes para promoção da aprendizagem. Pesquisadores indicam grupos de seis a oito alunos para o desenvolvimento ideal do PLTL. Quanto ao tempo, é indicado que as oficinas tenham a duração de 90 a 120 minutos. Intervalos mais restritos de tempo não se mostraram adequados na promoção de um trabalho produtivo para o desenvolvimento de habilidades na resolução de problemas;

- Apoio administrativo: as oficinas precisam ser apoiadas institucionalmente, tanto no que diz respeito ao provimento de espaços físicos e recursos materiais quanto no que concerne à aceitação de alterações na estrutura organizacional das próprias disciplinas.

Cabe destacar como os componentes anteriormente citados foram incorporados à atividade didática realizada no âmbito da presente pesquisa. Quanto ao envolvimento dos docentes e a integração das oficinas ao curso, tais requisitos foram cumpridos a contento, uma vez que os docentes deram ciência aos alunos sobre a sua existência no primeiro dia de aula e estimularam a participação dos mesmos, vinculando as atividades das oficinas àquelas ocorridas em sala.

No que tange ao material didático, os docentes ajudaram na sua confecção/organização, escolhendo os exercícios e os livros usados nas oficinas, dando qualidade e respaldo às atividades. Apesar dos docentes não terem selecionado o líder, destacamos que este participou de diversas atividades relacionadas à formação de grupo e preparação anterior na disciplina em questão, fatos que o qualificaram para a função. Em relação à formação do grupo, foram mantidas as principais características recomendadas na literatura: grupos de quatro a sete alunos e oficinas com duração de 90 a 120 minutos. Com relação ao apoio administrativo, este se concretizou apenas no oferecimento de espaço físico para a realização das oficinas. 


\subsection{Modelo Analítico de Kumpulainen e Mutanen}

O Modelo Analítico proposto por Kumpulainen e Mutanen (1999) apresenta como característica principal seu grande potencial em investigar a natureza das atividades sociais dos alunos, com enfoque especial nas interações verbais efetivadas em diferentes situações de aprendizagem. O modelo foi elaborado em uma pesquisa realizada com alunos do Ensino Fundamental, na Finlândia e na Inglaterra, na qual os participantes realizaram atividades em pequenos grupos (FOURLAS; WRAY, 1990; KUMPULAINEN, 1994; KUMPULAINEN, 1996; KUMPULAINEN; MUTANEN, 1998).

O Modelo Analítico foi desenvolvido inicialmente com o objetivo de analisar interações verbais entre os estudantes e determinar o seu papel nas atividades entre pares e também nas interações com os professores (FOURLAS; WRAY, 1990). Posteriormente, Kumpulainen testou, modificou e aplicou esse modelo em um estudo que investigava as atividades sociais desenvolvidas entre os alunos durante uma atividade de escrita colaborativa (KUMPULAINEN, 1994; KUMPULAINEN, 1996). Nesse contexto, o uso do Modelo Analítico visou evidenciar as estruturas e a qualidade das interações e, embora apresentasse um grande potencial de análise, não foi considerado pronto para desvendar o processo de aprendizagem social compartilhada em toda sua complexidade.

Por esse motivo, Kumpulainen e Mutanen (1999) decidiram desenvolver um sistema de análise descritiva com uma perspectiva mais holística e multidimensional, o que os levou a buscar um Modelo que fosse além das interações verbais e que se mostrasse capaz de desvendar a construção do conhecimento, valorizando o caráter da atividade, momento a momento, tendo como unidade de análise, ao mesmo tempo, o aluno e o seu grupo (KUMPULAINEN; MUTANEN, 1999).

Os interesses acima descritos direcionaram os pesquisadores à formulação do Modelo Analítico de três dimensões utilizado por nós, que descreve a dinâmica das interações estabelecidas entre os estudantes da perspectiva de cada uma delas, descritas a seguir: funções da fala, processamento cognitivo e processamento social. 


\section{Primeira dimensão: funções de fala}

Desenvolvidas para permitir a investigação das estratégias comunicativas adotadas pelos alunos durante a interação com seus colegas, as funções de fala buscam determinar quais são os possíveis significados funcionais das falas utilizadas pelos alunos no processo de interação. As funções de fala têm como característica refletir as expectativas dos alunos frente ao contexto sociocultural da atividade didática e, simultaneamente, permitem analisar e interpretar a evolução das situações criadas no decorrer da atividade, culminando em uma análise intra e interpessoal.

O processo de identificação das funções de fala está primariamente ligado ao conteúdo da fala do orador, ou seja, àquilo que sua fala pode implicar ou sugerir. Entretanto, em alguns casos, a identificação da função de fala não tem relação direta com o significado literal do que foi dito. Dessa forma, nem sempre a função é reflexo direto da forma linguística, mas do contexto, em termos de sua retrospectiva e prospectiva, tanto no que se refere ao conteúdo como à forma. Quando isto é levado em consideração, uma expressão pode ser considerada como unidade de intervenção, ou uma unidade de mensagem, sendo que a divisão de cada elocução é linguisticamente pautada pelas pistas referentes ao contexto em que foi dita. Assim, uma expressão pode servir a mais de uma função, da mesma forma que múltiplas funções podem ser identificadas em uma mesma emissão.

As funções podem ser divididas entre as que descrevem a natureza da interação com enfoque nas demandas necessárias para execução da tarefa e as que enfocam na perspectiva social ou cognitiva das relações estabelecidas no grupo. O Quadro 2 ilustra as funções de falas, adaptadas para a nossa análise, com base no trabalho de Kumpulainen e Mutanen (1999).

Quadro 2 - Categorização e descrição das funções de falas (adaptação do trabalho de Kumpulainen e Mutanen (1999)).

\begin{tabular}{|c|l|}
\hline Categoria & \multicolumn{1}{c|}{ Descrição } \\
\hline $\begin{array}{c}\text { Informação } \\
\text { (Inf) }\end{array}$ & $\begin{array}{l}\text { É caracterizada quando ocorre o fornecimento de informação, desde que } \\
\text { essa informação não tenha como objetivo responder uma pergunta ou } \\
\text { organizar ideia ou ação. }\end{array}$ \\
\hline $\begin{array}{c}\text { Avaliação } \\
\text { (Ava) }\end{array}$ & $\begin{array}{l}\text { É caracterizada quando o aluno faz uma avaliação de uma ação ou ideia } \\
\text { que tenha partido do grupo ou de um membro do grupo. }\end{array}$
\end{tabular}


Quadro 2 - Categorização e descrição das funções de falas (adaptação do trabalho de Kumpulainen e Mutanen (1999))

\begin{tabular}{|c|c|}
\hline Categoria & Descrição \\
\hline $\begin{array}{l}\text { Interrogação } \\
\quad(\text { Int) }\end{array}$ & $\begin{array}{l}\text { É caracterizada quando o aluno elabora uma questão ou faz referência a } \\
\text { uma questão feita pelo professor ou por outro membro do grupo. }\end{array}$ \\
\hline $\begin{array}{l}\text { Resposta direta } \\
\text { (Res) }\end{array}$ & $\begin{array}{l}\text { É caracterizada quando a fala do aluno busca responder uma pergunta } \\
\text { dita anteriormente de forma simples e objetiva. }\end{array}$ \\
\hline $\begin{array}{l}\text { Resposta critica } \\
\quad \text { (Res-C) }\end{array}$ & $\begin{array}{l}\text { É caracterizada quando a resposta do aluno parte de uma análise mais } \\
\text { aprofundada e elaborada. }\end{array}$ \\
\hline $\begin{array}{l}\text { Complemento de } \\
\text { resposta } \\
\text { (C-Res) }\end{array}$ & $\begin{array}{l}\text { E caracterizada por falas que complementam sentidos de respostas } \\
\text { dadas anteriormente. }\end{array}$ \\
\hline $\begin{array}{l}\text { Complemento de } \\
\text { resposta crítica } \\
\text { (C-Res-C) }\end{array}$ & $\begin{array}{l}\text { É caracterizada por falas que complementam sentidos de respostas que } \\
\text { partam de uma análise mais aprofundada, que tenham sido dadas } \\
\text { anteriormente. }\end{array}$ \\
\hline $\begin{array}{l}\text { Organização de ação } \\
\text { (Org-A) }\end{array}$ & $\begin{array}{l}\text { É caracterizada quando a fala do aluno tem o objetivo de organizar o } \\
\text { grupo ou a atividade. }\end{array}$ \\
\hline $\begin{array}{l}\text { Organização de ideia } \\
\text { (Org-I) }\end{array}$ & $\begin{array}{l}\text { É caracterizada quando a fala do aluno tem o objetivo de organizar as } \\
\text { ideias expostas buscando a melhor resposta. }\end{array}$ \\
\hline $\begin{array}{l}\text { De julgamento } \\
\text { (Jul) }\end{array}$ & $\begin{array}{l}\text { É caracterizada quando as falas buscam concordar ou discordar com } \\
\text { ações ou ideias dos demais membros do grupo. }\end{array}$ \\
\hline $\begin{array}{l}\text { Citação crítica } \\
\text { (Cit-C) }\end{array}$ & É caracterizada quando o aluno tenta justificar ou refutar ideias ou ações. \\
\hline $\begin{array}{l}\text { Leitura em voz alta } \\
\qquad \text { (LVA) }\end{array}$ & $\begin{array}{l}\text { É caracterizada pela leitura de um material em voz alta. Seja esse } \\
\text { material produzido pelo leitor, por outro membro do grupo ou por } \\
\text { terceiros. }\end{array}$ \\
\hline $\begin{array}{l}\text { Experiencial } \\
(\text { Exp) }\end{array}$ & É caracterizada quando ocorre uma fala relatando experiências pessoais. \\
\hline $\begin{array}{l}\text { Afetiva } \\
\text { (Afe) }\end{array}$ & É caracterizada quando ocorre expressão de sentimentos. \\
\hline $\begin{array}{l}\text { Inclassificável } \\
\text { (Inc) }\end{array}$ & $\begin{array}{l}\text { É caracterizada por funções que não podem ser classificadas nas demais } \\
\text { funções. }\end{array}$ \\
\hline
\end{tabular}

Foram suprimidas as seguintes categorias do Modelo original, que era formado por quinze categorias: raciocínio, composição, revisão e ditado. A exclusão ocorreu porque a estrutura e a complexidade das atividades desenvolvidas tornaram sua ocorrência praticamente nula. Também houve uma alteração na função argumentação, que foi substituída pela função de citação crítica. Isso se fez necessário quando se verificou que, em um grupo de cinco alunos, raramente aconteceria uma argumentação completa realizada por um só aluno. Porém, cabe lembrar que os argumentos são construídos em processo colaborativo e se formam baseados em partes menores que denominamos como citação crítica.

Outra modificação foi a subdivisão das categorias resposta e organização, dando origem às seguintes categorias: resposta direta, complemento de resposta, 
resposta crítica, complemento de resposta crítica, organização de ação e organização de ideia. E, por fim, adicionamos a função inclassificável.

A divisão da categoria resposta deveu-se à necessidade de adequar as funções à atividade por nós proposta, a qual tinha como característica a possibilidade de gerar respostas diferenciadas e com objetivos diversos. Na mesma senda, o número de alunos por atividade revelou um tipo diferente de função de fala, direcionada a organizar as ideias e reflexões apresentadas pelo grupo, diferentemente do trabalho original, no qual os alunos trabalham em duplas, o que justificou a subdivisão da categoria organização em dois tipos: de ação e de ideias.

Por último, acrescentamos a categoria inclassificável, que se fez necessária ao identificarmos determinadas funções que não se enquadravam em nenhuma das outras categorias existentes, além de outras que se mostravam incompletas ou incapazes de apresentar sozinhas uma unidade de mensagem.

\section{Segunda dimensão: processamento cognitivo}

$\mathrm{Na}$ segunda dimensão investigam-se as estratégias adotadas pelos alunos, do ponto de vista cognitivo, na resolução da atividade proposta pelo professor (Quadro 3).

Quadro 3 - Categorização e descrição dos processamentos cognitivos.

\begin{tabular}{|l|l|}
\hline \multicolumn{1}{|c|}{ Categorização } & \multicolumn{1}{|c|}{ Descrição } \\
\hline $\begin{array}{l}\text { Procedural } \\
\text { (PCR) }\end{array}$ & $\begin{array}{l}\text { Atividade rotineira, que exige apenas a manipulação, } \\
\text { organização e execução de tarefas sem análise reflexiva. }\end{array}$ \\
\hline $\begin{array}{l}\text { Off-task } \\
\text { (PCO) }\end{array}$ & Atividade não relacionada à tarefa solicitada pelo professor. \\
\hline $\begin{array}{l}\text { Interpretativo ou } \\
\text { Exploratório } \\
\text { (PCE) }\end{array}$ & $\begin{array}{l}\text { Atividade crítica e exploratória, que inclui planejamento, } \\
\text { levantamento de hipóteses, avaliação e experimentação. }\end{array}$ \\
\hline
\end{tabular}

Três estratégias cognitivas são sugeridas pelo Modelo de Kumpulainen e Mutanen (1999): a primeira, denominada de processamento procedural, está relacionada à sequência de passos conhecidos dados pelos alunos para alcançarem a solução do problema de forma objetiva (execuções rotineiras); a segunda, denominada de atividades off-task (fora do contexto da tarefa solicitada), está 
relacionada com momentos em que os alunos realizam atividades paralelas, que não estão relacionadas com a resolução do problema proposto pelo professor; a terceira, denominada processamento interpretativo ou exploratório, está relacionada com momentos nos quais o pensamento crítico é essencial e os alunos se mostram profundamente envolvidos com a atividade, buscando solucionar o problema proposto e abertos a explorar tudo o que a atividade proposta tem a oferecer. Nenhuma adaptação se fez necessária com relação à segunda dimensão do Modelo.

\section{Terceira dimensão: processamento social}

Na terceira dimensão investigam-se as relações sociais estabelecidas entre os alunos na resolução da atividade em grupo, observando-se o tipo de interação predominante que ocorre em um determinado intervalo de tempo. Foram considerados, no trabalho original, os seguintes tipos de interações: colaborativa, tutorial, argumentativa, individualista, dominante, competitiva e modos conflitantes. Este último caracteriza a interação durante um equívoco ou desentendimento entre os pares.

O modo competitivo relaciona-se com o desacordo, geralmente verificado em um nível social. O modo dominante relaciona-se com a distribuição de poder e status dentro do grupo de trabalho. O modo individualista e o dominante são opostos à interação do modo colaborativo. Os modos argumentativo e tutorial podem ser caracterizados como submodelos do modo colaborativo. O modo argumentativo relaciona-se a interações construtivas entre os alunos, que discutem diferentes perspectivas em um ambiente racional, apresentando julgamentos e justificavas, o que direciona os alunos, muitas vezes, a uma compreensão compartilhada da situação. O modo tutorial relaciona-se com a assistência dada por um aluno ou professor a outro aluno com o objetivo de ajudá-lo a compreender o assunto em pauta, incluindo, também, interações em que os estudantes buscam alcançar um entendimento mútuo da situação, sendo que as ideias são negociadas em conjunto e o discurso apresentado é coerente.

Com o intuito de adequar a terceira dimensão do Modelo a uma atividade com um número maior do que dois alunos, algumas adaptações se fizeram necessárias. 
Além da diferença com relação à quantidade de alunos por grupo, algumas das atividades que propusemos, diferentemente da original, contavam com a interação entre os alunos e o líder do PLTL, o que nos fez modificar a categoria tutorial para que esta se adequasse à nova realidade.

Dessa forma, consideramos que as interações podem ser basicamente de quatro tipos: colaborativo (caracterizado pela igual participação dos membros do grupo na realização das tarefas) e tutorial (caracterizado pelo auxílio prestado por um estudante ou professor a outro membro na realização da tarefa). O processamento social do tipo individualista é definido como confuso e pode ser caracterizado pelo trabalho individual do estudante, sem compartilhamento das dúvidas e conclusões com os demais membros do grupo, ou pelo domínio de um dos membros na realização da tarefa. O processamento social do tipo competitivo é definido como modo de conflito e pode ser caracterizado pela ocorrência de conflitos sociais ou acadêmicos não solucionados. $O$ processamento social do tipo nulo é caracterizado pela falta de compreensão entre os alunos ou da própria tarefa.

Faz-se necessário lembrar que, para a análise das três dimensões consideradas nesta pesquisa, não existem regras que restrinjam as categorias usadas, pois, conforme sugerido pelos autores (KUMPULAINEN; MUTANEN, 1999), o Modelo deve ser usado e adaptado considerando-se as peculiaridades dos diversos tipos de atividades de grupo. 


\section{PERCURSO METODOLÓGICO}

A pesquisa realizada assume um caráter de pesquisa qualitativa, uma vez que trabalhamos principalmente com a interpretação da fala, da escrita e das ações dos alunos durante aulas de Química. Somado a isso, nossa pesquisa tem como cenário o ambiente natural de aula como fonte direta de dados e o pesquisador como seu principal instrumento; os dados coletados são predominantemente descritivos; o processo é predominante em relação ao produto e a análise dos dados tende a seguir um processo indutivo. Esses aspectos caracterizam nossa pesquisa como qualitativa de acordo com Lüdke e André (1986).

Nossa análise contou com os seguintes métodos de coleta: observação, gravações em áudio e solicitação de trabalhos escritos dos alunos. Assim, foi necessária a transcrição das gravações das falas dos alunos, registradas no decorrer das aulas e nos encontros extraclasse ocorridos durante as atividades em pequenos grupos. Todo o processo de transcrição foi realizado com o cuidado de manter a fidelidade das falas correspondentes, o procedimento que utilizamos no que diz respeito às transcrições está de acordo com as recomendações de CARVALHO (2006):

As transcrições devem ser totalmente fieis às falas a que correspondem, sendo a substituição de termos por sinônimos terminantemente proibidos. Sobre a correção de erros de concordância existem dois pontos de vista diferentes entre os pesquisadores dessa área: um grupo acha que não se pode fazer as correções enquanto outro, recorrendo a posições éticas de um profissional estar analisando outro profissional, quase sempre colegas, e ainda a diferença existente entre a linguagem falada e a escrita, acha necessário que pequenas correções gramaticais sejam feitas nas apresentações dos dados. Existem também problemas com a pronúncia das palavras, por exemplo, nenhum paulista fala o " $r$ " no final dos verbos, mas isso não é um erro (...) sendo assim necessária na transcrição que as palavras sejam escritas corretamente (CARVALHO, 2006, p.154).

Com relação aos erros de concordância, optamos pela correção gramatical de algumas citações, como é sugerido pelo segundo ponto de vista apresentado pela autora.

As atividades em pequenos grupos descritas neste capítulo foram aplicadas em três turmas distintas, sendo a primeira realizada durante a nossa pesquisa de mestrado (TEODORO, 2011; TEODORO; CABRAL; QUEIROZ, 2015) e as demais realizadas durante nossa pesquisa de doutorado. Assim, trabalhamos com três 
turmas em diferentes disciplinas. A seguir são descritos cada um dos contextos de aplicação das atividades nas turmas denominadas A, B e C.

\subsection{Contexto de aplicação das atividades em pequenos grupos na Turma A}

As atividades em pequenos grupos (formato jigsaw) realizadas na Turma $\mathrm{A}$ foram levadas a cabo nas aulas da disciplina Comunicação e Expressão em Linguagem Científica ${ }^{1}$, oferecida aos alunos ingressantes no Curso de Bacharelado em Química do Instituto de Química de São Carlos.

A disciplina teórica, de caráter obrigatório, é ministrada em duas horas semanais (dois créditos aula e um credito trabalho) e visa à discussão das diversas formas como a Ciência é divulgada, à apresentação aos estudantes de alguns tipos de documentos científicos e suas características peculiares, assim como de fontes de informação em ciência e tecnologia. Ações que buscam a promoção de discussões sobre a importância da comunicação científica para o profissional da área de Química, com ênfase no papel da linguagem escrita, são também realizadas na disciplina, tradicionalmente ministrada a partir da realização de aulas expositivas, de trabalhos em grupo e de aulas práticas na biblioteca.

No primeiro dia de aula, a disciplina contava com 51 alunos matriculados e ao final do semestre com 62 , os onze alunos adicionais se juntaram à turma devido às chamadas subsequentes à primeira chamada do vestibular. Os 51 alunos inicialmente engajados na disciplina foram distribuídos em grupos cooperativos heterogêneos, uma vez que responderam a um questionário de caracterização que subsidiou a sua distribuição nos grupos. Os demais alunos não participaram da etapa de formação dos grupos heterogêneos, porém participaram das atividades cooperativas.

Os alunos foram divididos em doze grupos: dez grupos heterogêneos de cinco membros e dois grupos de seis membros não heterogêneos. Selecionamos aleatoriamente dois grupos heterogêneos compostos por cinco alunos, acompanhamos suas atividades e registramos seus diálogos em áudio. Nessa perspectiva, dez alunos foram tomados como sujeitos na investigação das 
interações discursivas estabelecidas nas atividades realizadas no modelo cooperativo jigsaw. A atividade constou de cinco etapas:

\section{Etapa 1: Formação dos grupos heterogêneos}

Conforme mencionamos anteriormente, os grupos heterogêneos foram formados com base na aplicação de um questionário de caracterização (30 questões, divididas em 4 blocos) preenchido pelos alunos no primeiro dia de aula (TEODORO, 2011). Para a formação dos grupos heterogêneos, lançamos mão dos seguintes critérios: (i) formação estudantil do aluno e (ii) habilidade em escrita e interesse e motivação pela leitura. Para a definição do primeiro critério, fizemos uso da sétima questão do Bloco 1, que indagava "Você teve alguma outra experiência acadêmica durante ou após esse período (outro curso de graduação, curso técnicoprofissionalizante, etc.)? Se sim, especifique." Consideramos as respostas fornecidas à questão, pois entendemos que os alunos que apresentam formação técnica ou advinda de outros cursos de graduação teriam mais facilidade para discorrer sobre a temática em pauta na disciplina.

O segundo critério foi definido ao analisarmos os textos produzidos pelos alunos na resolução do questionário. Selecionamos os que apresentavam uma boa escrita, tendo como base para considerar uma boa escrita o trabalho de Vidal (1998), que a define como sendo clara, legível, rápida, elegante e com liberdade de execução. Também usamos como parâmetro para o segundo critério os questionamentos encontrados nos Blocos 2 e 3: "Quantos livros você lê, em média, por ano?"; "Verifique a lista de revistas de divulgação científica citadas a seguir e assinale aquelas que você já teve a oportunidade de ler."; "Na maioria das vezes, com que finalidade você lê?"; "Acha importante a leitura? Por quê?"; "Quando vai estudar como é a sua relação com a leitura?"; "Quando lê com outro propósito o faz da mesma maneira?". Considerando as respostas fornecidas às questões, definimos os alunos que apresentavam maior interesse e motivação pela leitura.

Tendo em mãos os resultados dos questionários, separamos os alunos em três grupos com o intuito de, a partir dessa classificação inicial, redistribuí-los em dez grupos de característica heterogênea: o grupo $A$, composto pelos alunos que atenderam aos dois critérios; o grupo $\mathrm{B}$, composto pelos alunos que atenderam 
apenas um dos critérios; o grupo C, composto pelos alunos que não atenderam a nenhum dos dois critérios. Assim, dos 51 alunos que responderam ao questionário, dezoito formaram o grupo A, 24 formaram o grupo B, e 9 formaram o grupo C.

Primeiramente, distribuímos os alunos do grupo A nos dez grupos heterogêneos. Dessa forma, cada grupo contou com pelo menos um aluno com curso superior (completo ou incompleto) ou técnico. Esta medida nos pareceu relevante ao considerarmos que tais alunos provavelmente tiveram maior contato com documentos do tipo que seria estudado na disciplina e poderiam direcionar as atividades auxiliando seus companheiros de forma mais efetiva.

Em seguida, distribuímos os alunos do grupo B de forma que cada grupo dos dez grupos heterogêneos contou com a presença de pelo menos dois alunos vindos do referido grupo. Tendo em vista que a maioria dos alunos atendeu ao segundo critério, apresentando interesse e motivação pela leitura, consideramos que eles poderiam ajudar os demais alunos na elaboração e resolução das tarefas.

Por último, distribuímos os alunos do grupo C, de forma que, dos dez grupos heterogêneos, nove contaram com a presença de um aluno do referido grupo.

\section{Etapa 2: Aulas iniciais (expositivas dialogadas)}

Ainda no primeiro dia de aula, o docente apresentou a disciplina, informando o conteúdo a ser ministrado e seus principais objetivos. Após a apresentação, os alunos entraram em contato com a proposta do nosso projeto e concordaram em participar como sujeitos da pesquisa, assinando o Termo de Consentimento e Informação (TEODORO, 2011).

No segundo dia de aula, os alunos conheceram as distribuições dos grupos de base e assistiram a uma aula sobre aprendizagem cooperativa, com foco especial no funcionamento do método jigsaw. A apresentação teve como objetivo dar conhecimento aos alunos sobre a metodologia e seus fundamentos e explicar como esta seria aplicada na disciplina (interdependência de papéis, interdependência de recompensa, processamento grupal etc), assim como sanar possíveis dúvidas existentes por parte dos alunos. Em seguida, o docente indicou uma referência completa de cada um dos seguintes tipos de documento que deveriam ser trazidos pelos membros dos grupos de base para a aula seguinte 
(TEODORO, 2011): artigo científico original de pesquisa; artigo de revisão; artigo de divulgação científica; artigo de educação em Química; tese ou dissertação.

\section{Etapa 3: Aula pautada no trabalho dos grupos de base (parte I)}

No terceiro dia de aula, os alunos reuniram-se nos chamados grupos de base, cada aluno com seu respectivo documento. Assim, cada grupo composto por cinco alunos detinha um tipo de cada um dos documentos solicitados pelo docente, como apresentado na Figura 11. Para realização da atividade, foi entregue aos alunos um questionário relativo aos documentos que o grupo tinha em mãos (TEODORO, 2011). O objetivo do questionário foi buscar uma resposta coletiva dos alunos sobre as características dos diferentes documentos.

Figura 11 - Apresentação dos grupos de base, cada grupo composto por cinco alunos, cada um com um tipo de documento.

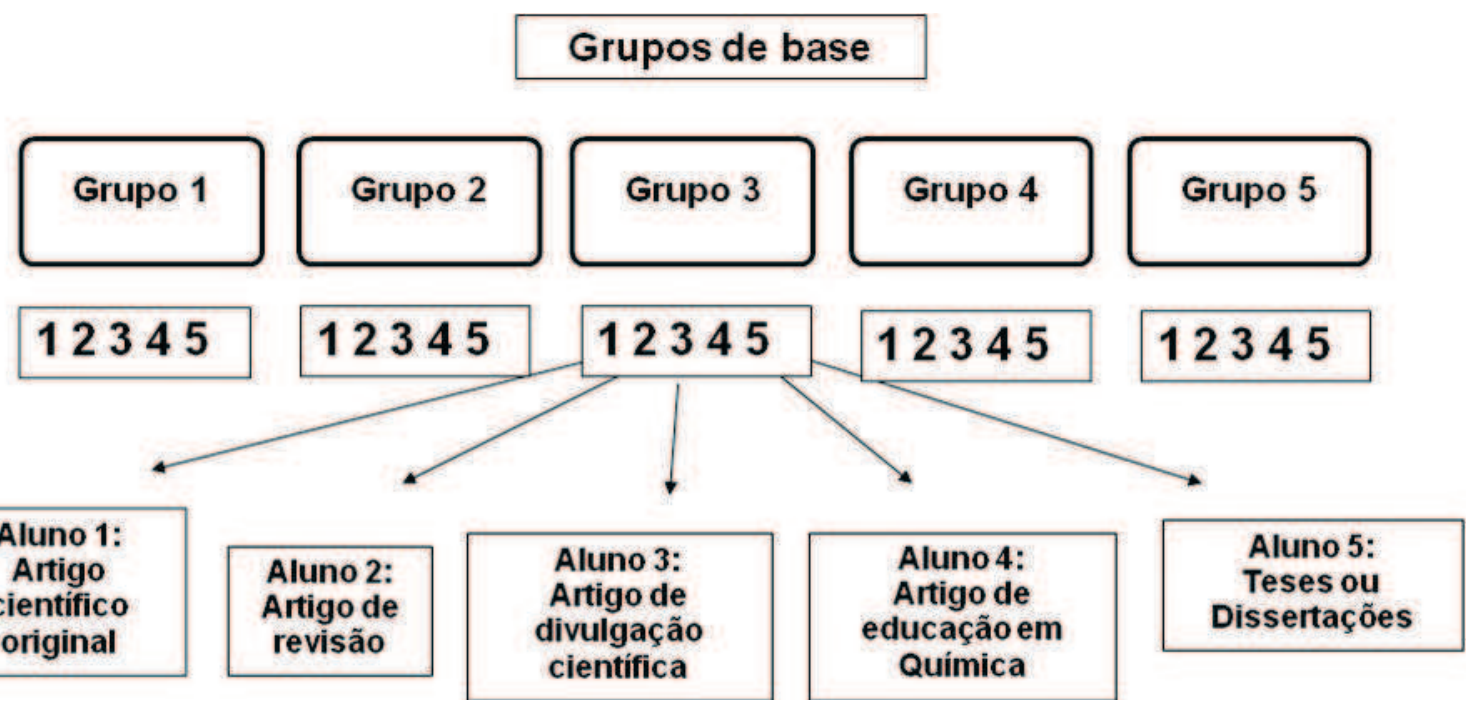

Cabe lembrar que, dentro do grupo de base, cada aluno era responsável por exercer uma das seguintes funções determinadas pelo docente: mediador, relator, redator, porta voz e facilitador/gestor de recursos. Ao final da atividade, os alunos realizaram o processamento grupal, respondendo às seguintes solicitações: "Indiquem pelo menos três atitudes/procedimentos do grupo que favoreceram o desenvolvimento do trabalho realizado na aula de hoje" e "Indiquem também 
algumas atitudes/procedimentos do grupo que podem vir a melhorar o desempenho do grupo nas próximas atividades".

Ao final da aula, os alunos foram incumbidos de realizar uma atividade extraclasse (TEODORO, 2011), contendo questões relacionadas às características estruturais dos seus respectivos documentos.

\section{Etapa 4: Aula pautada no trabalho dos grupos de especialistas}

No quarto dia de aula, os alunos de grupos de base diferentes, mas que foram designados a estudar o mesmo documento, discutiram sobre os seus documentos específicos em um novo grupo (denominado grupo de especialistas). Assim, por exemplo, os alunos especialistas em artigos de divulgação científica investigaram características comuns a textos desse tipo, porém provenientes de revistas distintas, conforme ilustra a Figura 12.

Figura 12 - Constituição do grupo de especialistas em artigos de divulgação científica.

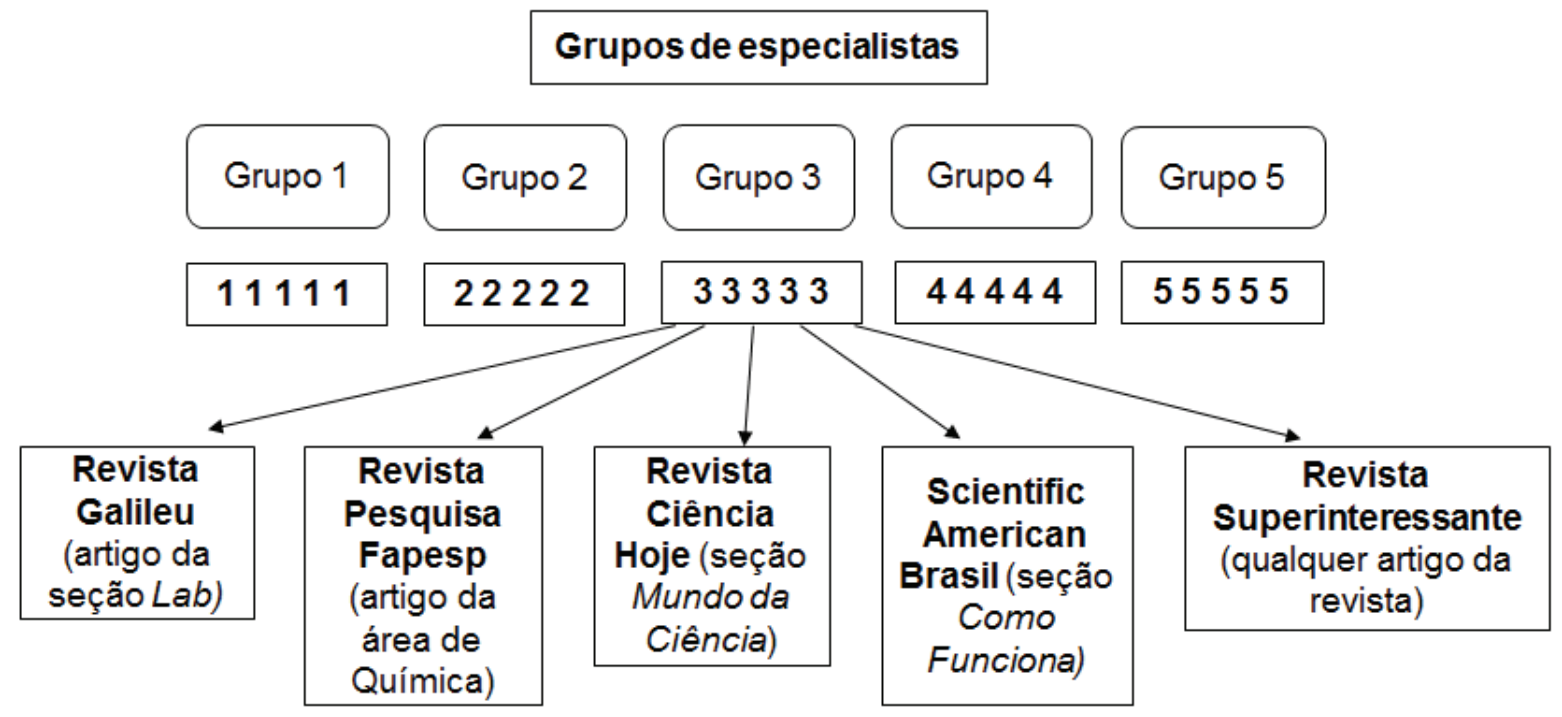

$\mathrm{Na}$ ocasião, o docente entregou uma nova atividade (TEODORO, 2011), a partir da qual os alunos tiveram um contato mais aprofundado sobre as características do seu documento específico. Cada aluno apresentou as respostas dadas para atividade extraclasse (TEODORO, 2011) e, após uma discussão, chegaram a uma resposta considerada melhor pelo grupo. Por fim, desenvolveram um texto sobre o documento estudado. 


\section{Etapa 5: Aula pautada no trabalho dos grupos de base (parte II)}

No quinto dia de aula, os alunos participantes dos grupos de especialistas retornaram aos seus grupos de base e compartilharam com os demais alunos o conhecimento ali adquirido. Além do conhecimento adquirido, cada aluno tinha em mãos um texto organizado sobre seu documento e, a partir dessa nova perspectiva, os alunos aprimoraram as questões produzidas na atividade inicial solicitada aos grupos de base (TEODORO, 2011), agora munidos de uma visão privilegiada sobre a totalidade dos documentos. Assim, no final da realização do jigsaw, todos os membros dos grupos entraram em contato com todo o conteúdo.

Ao final dessa atividade, os alunos realizaram novamente o processamento grupal.

\subsection{Contexto de aplicação das atividades em pequenos grupos na Turma B}

As atividades em pequenos grupos (formato PLTL) realizadas na Turma $B$ foram levadas a cabo na disciplina Cinética Química: Teoria e Prática ${ }^{2}$, oferecida aos alunos do terceiro ano do Curso de Bacharelado em Química do Instituto de Química de São Carlos.

A disciplina teórico-prática, de caráter obrigatório, é ministrada em quatro horas semanais (quatro créditos aula e um credito trabalho) e visa à discussão dos fundamentos básicos da Cinética Química, tratando de generalidades, termos usuais e definições como: dependência da velocidade de reação com os termos de concentração; leis de velocidade; dependência das equações de velocidade método diferencial; integração das leis de velocidade - meia vida; reações opostas reações paralelas - reações consecutivas e estado estacionário. Métodos Experimentais: utilização das equações de velocidade com medidas experimentais; dependência das velocidades de reação com a temperatura - equação de Arrhenius; energia de ativação; outras equações; teoria das colisões; complexo ativado; diagrama de energia versus coordenada de reação; formulação termodinâmica;

\footnotetext{
${ }^{2}$ As informações completas sobre a disciplina se encontram no site: https://uspdigital.usp.br/jupiterweb/obterDisciplina?sgldis=SQF0331\&verdis=1
} 
teoria absoluta (Introdução); reação em solução; catálise; reações unimoleculares e reações em cadeia.

No primeiro dia de aula a disciplina contava com 45 alunos matriculados, não ocorrendo nenhuma adição ou desistência, este número se manteve até o final do semestre. Dos 45 alunos matriculados, doze participaram da pesquisa.

Os doze alunos foram distribuídos em dois grupos: um grupo heterogêneo de seis membros (formato cooperativo) e um grupo não heterogêneo de seis membros (formato colaborativo PLTL). Selecionamos o grupo não heterogêneo composto por seis alunos, acompanhamos suas atividades e registramos seus diálogos em áudio. Como não analisamos as atividades realizadas no grupo cooperativo, não apresentamos a descrição das etapas nele seguidas. Nessa perspectiva, seis alunos foram tomados como sujeito na investigação das interações discursivas estabelecidas nas atividades realizadas no modelo colaborativo PLTL. A atividade constou de três etapas:

\section{Etapa 1: Formação dos grupos PLTL não heterogêneos}

O grupo PLTL foi formado de maneira não heterogênea, uma vez que a heterogeneidade não é uma prerrogativa exigida na construção de grupos dessa natureza. Entretanto, outras exigências devem ser consideradas na formação desses pequenos grupos, dentre as quais estão: a integração da atividade com a disciplina e com o conteúdo e a presença do chamado líder-par.

A integração deve ocorrer por meio da participação efetiva do docente responsável pela disciplina em todas as atividades do grupo, mesmo as que ocorram em período extraclasse, assim como no planejamento e desenvolvimento das atividades e dos materiais utilizados. O líder-par, necessariamente, deve ser um aluno que já cursou a disciplina e obteve um bom resultado, tendo conhecimento do conteúdo a ser aprendido, apresentando também boa capacidade de comunicação e potencial de liderança (GOSSER JR; KAMPMEIER; VARMA-NELSON, 2010). O papel de líder-par dos grupos ficou ao nosso encargo, uma vez que atendemos aos pré-requisitos indicados para a função: conhecimento vasto do conteúdo e perfil de liderança. 


\section{Etapa 2: Aulas Iniciais (Expositivas Dialogadas)}

No primeiro dia de aula, o docente apresentou a disciplina, informando o conteúdo a ser ministrado e seus principais objetivos. Após a apresentação, os alunos entraram em contato com a proposta do nosso projeto e os alunos que participaram como sujeitos da pesquisa, assinaram o Termo de Consentimento e Informação (Apêndice B). Cabe ressaltar que a atividade, apesar de estar integrada ao conteúdo ministrado em sala de aula, não era obrigatória e os encontros foram realizados em período extraclasse.

\section{Etapa 3: Atividade pautada no trabalho do grupo PLTL (parte I)}

No primeiro dia de atividade extraclasse, que teve duração de sessenta minutos, os alunos reuniram-se no grupo colaborativo PLTL na biblioteca do Instituto de Química de São Carlos e, inicialmente, assistiram a uma explicação sobre aprendizagem colaborativa, com foco especial no funcionamento do método PLTL. A apresentação teve como objetivo dar conhecimento aos alunos sobre a metodologia e seus fundamentos e explicar como esta seria aplicada na disciplina, assim como sanar possíveis dúvidas existentes por parte dos alunos.

Na ocasião, o grupo foi solicitado a responder duas questões: 1) Do conteúdo ministrado pelo professor, qual você considera ser o mais complexo? Cite pelo menos dois tópicos, 2) Das listas de exercícios relacionados à segunda avaliação quais exercícios você considera que apresentam o maior nível de dificuldade? Escolha dois exercícios de cada uma das três listas.

As três listas de exercício foram elaboradas pelo docente responsável pela disciplina e cada uma delas tratava de um tema especifico que seria cobrado em avaliação. A primeira lista (Anexo A) era composta por dez exercícios e tratava especificamente do mecanismo de reações químicas; dessa lista os alunos escolheram os exercícios seis e nove como sendo os mais complexos. A segunda lista (Anexo B) era composta por dez exercícios e tratava especificamente da influência da temperatura na velocidade das reações; dessa lista os alunos escolheram os exercícios sete e onze como sendo os mais complexos. A terceira lista (Anexo C) era composta por dez exercícios e tratava especificamente da teoria 
das colisões; dessa lista os alunos escolheram os exercícios sete e nove como sendo os mais complexos.

\section{Etapa 4: Atividade pautada no trabalho do grupo PLTL (parte II)}

No segundo dia de atividade extraclasse, que teve a duração de sessenta minutos os alunos trabalharam com os exercícios escolhidos da primeira lista de exercícios. $\mathrm{Na}$ atividade, os alunos discutiram o assunto em foco, com o auxílio do líder-par, e chegaram às respostas que consideraram mais satisfatórias para as questões.

\section{Etapa 5: Atividade pautada no trabalho do grupo PLTL (parte III)}

No terceiro dia de atividade extraclasse, as etapas realizadas na parte II foram repetidas, com o diferencial de que o foco eram as questões escolhidas da segunda lista de exercícios.

\section{Etapa 6: Atividade pautada no trabalho do grupo PLTL (parte III)}

Por fim, no quarto dia de atividade extraclasse, os alunos repetiram as etapas realizadas na parte I e II, agora com foco nas questões escolhidas da terceira lista de exercícios.

\subsection{Contexto de aplicação das atividades em pequenos grupos na Turma C}

As atividades em pequenos grupos (formato jigsaw e formato PLTL) realizadas na Turma $\mathrm{C}$ foram levadas a cabo na disciplina Introdução à Química ${ }^{3}$, oferecida aos alunos ingressantes do Curso de Bacharelado em Química do Instituto de Química de São Carlos.

A disciplina teórica, de caráter obrigatório, é ministrada em quatro horas semanais (quatro créditos aula e um crédito trabalho) e visa à discussão e o 
fornecimento ao aluno de uma fundamentação teórica geral da Química, demonstrando a lógica do aprendizado e enfocando tanto aspectos fenomenológicos, quanto aplicações do dia a dia relacionadas aos conteúdos apresentados. O conteúdo programático é dividido em dois blocos. No primeiro bloco são estudados os tópicos: matéria, energia e transformação; características químicas; propriedades e medição da matéria; soluções, coloides e suspensões; misturas e substância puras; substâncias simples e compostas. No segundo bloco são estudados os tópicos: aspectos fenomenológicos de gases, líquidos e sólidos; estequiometria; energia e termoquímica; equilíbrio químico; cinética química; classificação de ácidos e bases, força ácido-base, reações de neutralização; reações de oxirredução: características eletroquímicas. As aulas são tradicionalmente ministradas a partir da realização de aulas expositivas e resolução de exercícios.

No primeiro dia de aula a disciplina contava com sessenta alunos matriculados, não ocorrendo nenhuma adição ou desistência, este número se manteve até o final do semestre, com os alunos divididos em duas turmas de forma igualitária, cada uma com seu respectivo docente. Participaram, inicialmente, das atividades didáticas, realizadas em período extraclasse, 34 alunos, sendo dezessete alunos provenientes de cada turma. Estes responderam a um questionário de caracterização (Apêndice $\mathrm{C}$ ) que subsidiou a formação de cinco grupos cooperativos heterogêneos. Além dos cinco grupos no formato jigsaw, mais dois grupos no formato PLTL foram formados. Para a formação desses grupos não foram consideradas as respostas oferecidas no questionário de caracterização.

Assim, os alunos foram divididos em sete grupos, cinco grupos heterogêneos de cinco membros (formato jigsaw) e dois grupos não heterogêneos de cinco e quatro membros (formato PLTL). Acompanhamos as atividades e registramos os diálogos em áudio dos sete grupos. Dos 34 alunos participantes, 23 cumpriram todas as etapas. Nessa perspectiva, 23 alunos foram tomados como sujeitos na investigação das interações discursivas estabelecidas nos cinco grupos cooperativos jigsaw e nos dois grupos colaborativos PLTL. A atividade no formato jigsaw constou de cinco etapas e no formato PLTL constou de cinco etapas. 


\subsubsection{Atividade Formato Jigsaw}

\section{Etapa 1: Formação dos grupos heterogêneos}

Conforme mencionamos anteriormente, os grupos heterogêneos foram formados com base na aplicação de um questionário de caracterização (dezessete questões, divididas em três blocos) preenchido pelos alunos no primeiro dia de aula (Apêndice C). Para a formação dos grupos heterogêneos, lançamos mão dos seguintes critérios: (i) formação estudantil do aluno e (ii) conhecimento específico na área de Química.

Para a definição do primeiro critério, fizemos uso da sexta questão do Bloco 1, que indagava "Você teve alguma outra experiência acadêmica durante ou após esse período (outro curso de graduação, curso técnico-profissionalizante, etc.)? Se sim, especifique." Consideramos as respostas fornecidas à questão, pois entendemos que os alunos que apresentam formação técnica ou advinda de outros cursos de graduação teriam mais facilidade para discorrer sobre a temática em pauta na disciplina.

Para a definição do segundo critério, analisamos os textos produzidos pelos alunos na resolução das questões do Bloco 2 e 3 , que foram adaptadas do trabalho de França, Marcondes e Carmo (2009). Foi solicitado aos alunos que fizessem uma representação da estrutura de um átomo e de um íon, assim como que respondessem aos seguintes questionamentos: "Quais fatores são usados para separar os elementos na tabela periódica?"; "O fato de um átomo perder ou ganhar elétrons pode afetar seu volume atômico, explique essa relação."; "Defina o que é química orgânica e faça sua correlação com a Química inorgânica?”; "As ligações Químicas podem apresentar um caráter iônico, covalente ou metálico, indique como podemos diferenciar esse caráter em substâncias diferentes?".

Tendo em mãos as respostas às questões citadas, separamos os alunos em três grupos com o intuito de, a partir dessa classificação inicial, redistribuí-los em cinco grupos de característica heterogênea. Para tanto, fizemos uma categorização inicial, na qual alunos com desempenho acima da média nos Blocos 1 e 2 do questionário, referentes à formação acadêmica e ao conhecimento de Química, foram reunidos no grupo $A$. O grupo $B$ reuniu alunos que apresentaram desempenho acima da média em apenas um dos critérios e o grupo $C$ foi formado com os alunos 
que não atenderam respectivamente a nenhum dos dois critérios. Assim, dos 25 alunos, seis formaram o grupo A, 14 formaram o grupo B e cinco formaram o grupo C.

Em seguida, distribuímos os alunos do grupo A nos cinco grupos de base heterogêneos, de forma que cada grupo contou com pelo menos um aluno com curso superior (completo ou incompleto) ou técnico. Esta medida nos pareceu relevante ao considerarmos que tais alunos provavelmente tiveram contato anterior com os conteúdos abordados na disciplina introdutória em questão e que poderiam direcionar as atividades, auxiliando seus companheiros de forma mais efetiva. $\mathrm{Na}$ sequência, distribuímos os alunos do grupo $B$ de forma que cada grupo, dos cinco grupos heterogêneos, contou com a presença de pelo menos dois alunos provenientes do grupo B. Por último, distribuímos os alunos do grupo $\mathrm{C}$ de forma que, dos cinco grupos heterogêneos, todos contaram com a presença de um aluno do grupo $\mathrm{C}$.

\section{Etapa 2: Aulas iniciais (expositivas dialogadas)}

Ainda no primeiro dia de aula, o docente apresentou a disciplina, informando o conteúdo a ser ministrado e seus principais objetivos. Após a apresentação, os alunos entraram em contato com a proposta do nosso projeto e os que concordaram em participar como sujeitos da pesquisa, assinaram o Termo de Consentimento e Informação (Apêndice D).

\section{Etapa 3: Atividade pautada no trabalho dos grupos de base (parte l)}

No primeiro dia de atividade extraclasse, que teve duração de aproximadamente sessenta minutos, ocorrida em uma sala de aula do IQSC, os alunos reuniram-se nos grupos de base, constituídos por cinco alunos. Foi entregue a cada grupo um questionário composto por cinco questões, relativos ao tema Equilíbrio Químico, abordado em sala pelos docentes (Apêndice E). O objetivo da sua aplicação foi buscar uma resposta coletiva dos alunos sobre os questionamentos. 
Figura 13 - Apresentação dos grupos de base, cada grupo composto por cinco alunos, cada um com um tipo de documento.

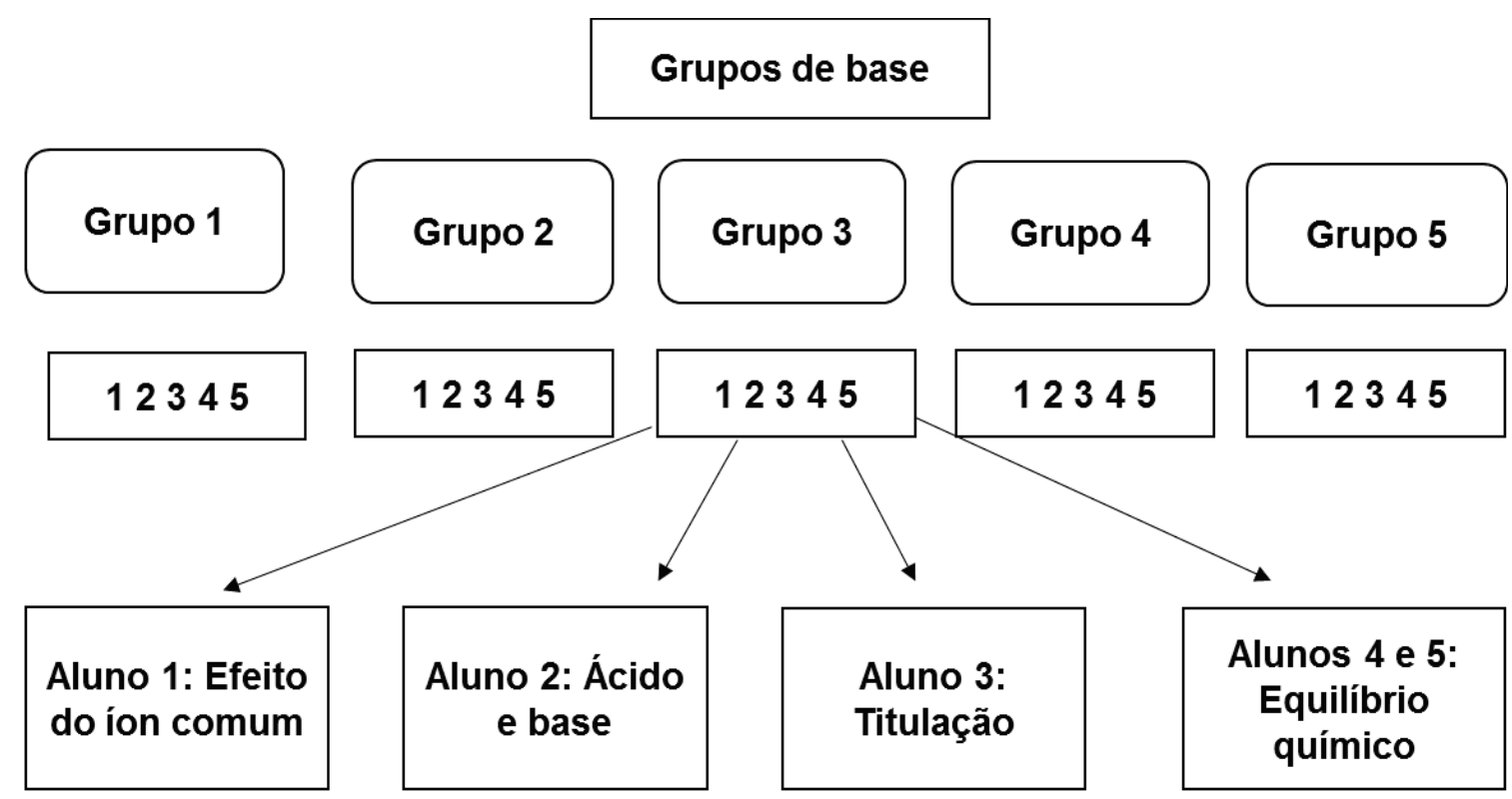

Ao final do preenchimento do questionário, os alunos foram incumbidos de realizar uma atividade extraclasse preparatória para as atividades que seriam levadas a cabo nos grupos de especialistas. Cada aluno ficou responsável por aprofundar seus conhecimentos em um dos quatro tópicos: Efeito do ĺon Comum; Ácido e Base; Titulação e Equilíbrio Químico. Cabe lembrar que, como cada grupo era composto por cinco alunos, o tópico Equilíbrio Químico foi designado para dois alunos de cada grupo. Os alunos foram orientados a pesquisar os tópicos em dois livros distintos de Química Geral (ATKINS; JONES, 2006; MAHAN; MYERS,1995).

\section{Etapa 4: Atividade pautada no trabalho dos grupos de especialistas}

No segundo dia de atividade, os alunos de grupos de base diferentes, mas que foram designados a estudar o mesmo tópico, discutiram sobre o tópico específico em um novo grupo (denominado grupo de especialistas). Assim, por exemplo, os alunos especialistas em Equilíbrio Químico investigaram características comuns ao tema, tratando o tópico na perspectiva dos dois livros indicados. Nesse dia, os alunos receberam um novo questionário (Apêndice $F$ ), a partir do qual tiveram um contato mais aprofundado sobre as características do seu tópico específico. 
Figura 14 - Constituição dos grupos de especialistas nas temáticas específicas da disciplina Introdução a Química.

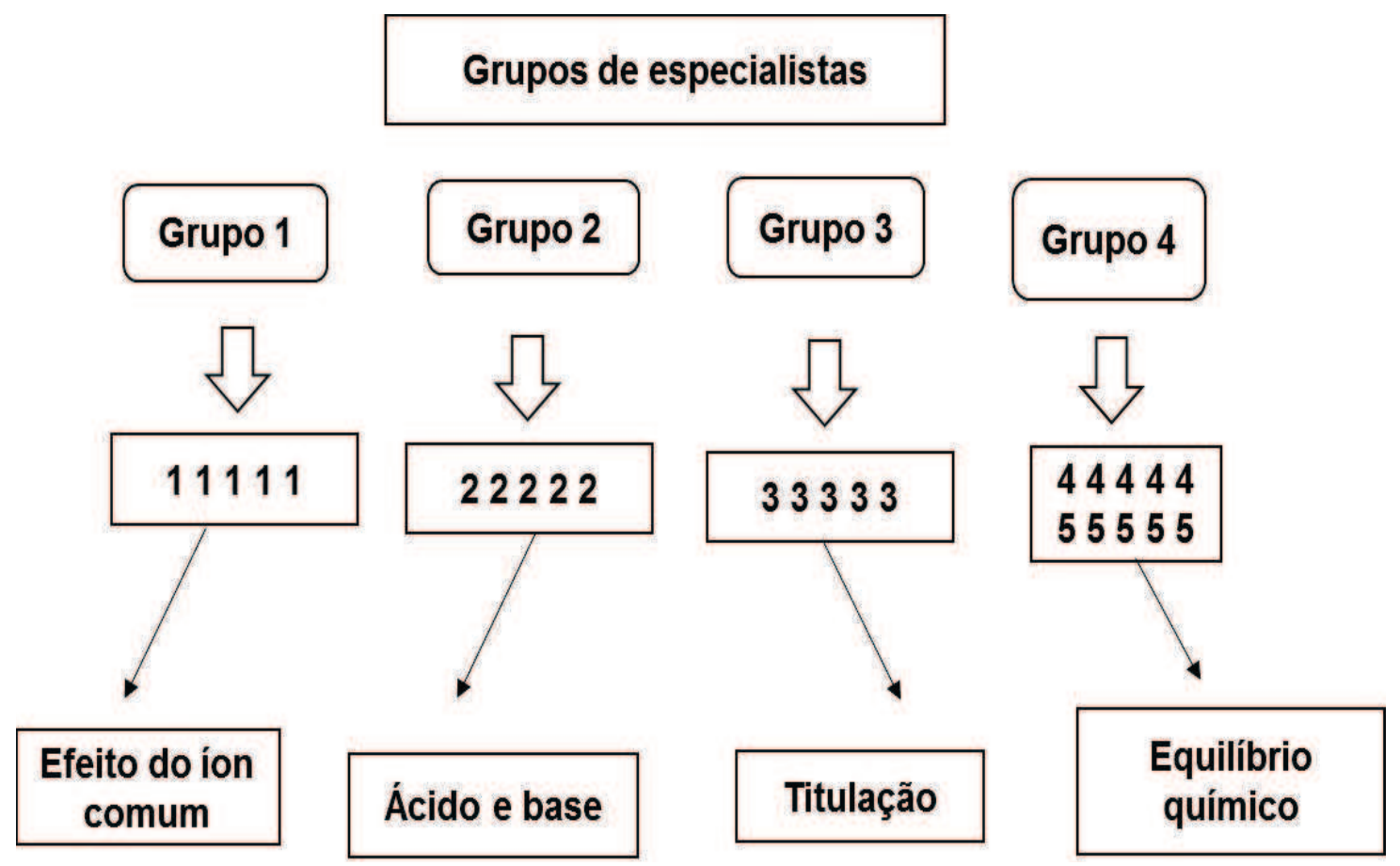

Ou seja, um questionário foi desenvolvido de forma específica para cada tópico: Efeito do ĺon Comum (composto de cinco questões); Ácido e Base (composto de três questões); Titulação (composto por três questões) e Equilíbrio Químico (composto por cinco questões). Em seguida, foi promovida uma discussão de modo que os alunos chegaram a uma resposta considerada satisfatória pelo grupo e desenvolveram um material que representava a melhor resposta para o grupo.

\section{Etapa 5: Atividade pautada no trabalho dos grupos de base (parte II)}

No terceiro dia de atividade, os alunos participantes dos grupos de especialistas retornaram aos seus grupos de base e compartilharam com os demais alunos o conhecimento ali adquirido. Nesse contexto, os alunos aprimoraram seus conhecimentos e produziram respostas para um novo questionário com os mesmos preceitos do inicial, porém com um grau de dificuldade maior (Apêndice $G$ ). Este contava com cinco questões que tratavam dos quatro temas abordados anteriormente de forma a relacioná-los dando mais profundidade ao conteúdo. Os alunos estavam, a princípio, munidos de uma visão privilegiada sobre os tópicos 
apresentados. Assim, no final da realização do jigsaw todos os membros dos grupos entraram em contato com todos os tópicos da atividade.

\subsubsection{Atividade Formato PLTL}

\section{Etapa 1: Formação dos grupos não heterogêneos}

Os grupos PLTL foram formados de maneira não heterogênea, uma vez que a heterogeneidade não é uma prerrogativa exigida na construção de grupos dessa natureza. Entretanto, outras exigências devem ser consideradas na formação desses pequenos grupos, conforme mencionado anteriormente. Formamos dois grupos PLTL com número de quatro a cinco alunos. O papel de líder-par dos grupos ficou ao nosso encargo, uma vez que atendemos aos pré-requisitos indicados para a função: conhecimento vasto do conteúdo e perfil de liderança.

\section{Etapa 2: Aulas iniciais (expositivas dialogadas)}

Ainda no primeiro dia de aula, o docente apresentou a disciplina, informando o conteúdo a ser ministrado e seus principais objetivos. Após a apresentação, os alunos entraram em contato com a proposta do nosso projeto e os que concordaram em participar como sujeitos da pesquisa, assinaram o Termo de Consentimento e Informação (Apêndice D).

\section{Etapa 3: Primeira atividade nos grupos PLTL}

No primeiro dia de atividade extraclasse, que teve duração de aproximadamente sessenta minutos, os alunos reuniram-se nos grupos colaborativos PLTL em uma sala de aula do IQSC, formando dois grupos um com cinco alunos e um com quatro alunos. Foi entregue a cada grupo um questionário composto por cinco questões relativas ao conteúdo Equilíbrio Químico discutido em sala pelos docentes (Apêndice E). O objetivo do questionário foi buscar uma resposta coletiva dos alunos sobre esse tema que é central para a disciplina em questão, lembrando que para a formulação da resposta estes contariam com o auxílio do líder-par. 
Ao final da atividade, os alunos foram incumbidos de realizar uma pesquisa sobre os quatro tópicos que seriam abordados nos próximos encontros: Efeito do Íon Comum; Ácido e Base; Titulação e Equilíbrio Químico. Os alunos foram orientados a pesquisar os tópicos em dois livros distintos de Química Geral (ATKINS; JONES, 2006; MAHAN; MYERS,1995). Cabe lembrar que diferentemente da abordagem no formato jigsaw, a estrutura mais flexível dessa atividade permite aos alunos o compartilhamento com a sala de dúvidas que considerassem importantes.

\section{Etapa 4: Segunda atividade nos grupos PLTL}

No segundo dia de atividade, os alunos dos grupos PLTL se reuniram para trabalhar os tópicos principais da atividade, para tanto, foram entregues quatro questionários (Apêndice F), um para cada tópico: Efeito do ĺon Comum (composto de cinco questões); Ácido e Base (composto de três questões); Titulação (composto por três questões) e Equilíbrio Químico (composto por cinco questões). Em seguida, foi pedido para que os alunos em conjunto decidissem quais questões dentre as apresentadas eram mais relevantes para a atividade. Após a escolha, os alunos, juntamente com líder-par discutiram e chegaram a uma resposta considerada satisfatória. Por fim, desenvolveram um material que representava a melhor resposta para o grupo.

\section{Etapa 5: Terceira atividade nos grupos PLTL}

No terceiro dia de atividade, os alunos dos grupos PLTL reuniram-se para produzir respostas para um novo questionário com os mesmos preceitos do realizado na primeira atividade, porém com um grau de dificuldade maior (Apêndice G). Este contava com cinco questões que tratavam dos quatro temas abordados anteriormente de forma a relacioná-los dando mais profundidade ao conteúdo. Os alunos estavam, a princípio, munidos de uma visão privilegiada sobre os tópicos, decorrente das atividades anteriores. Nas três sessões, a atividade foi realizada com o auxílio do líder-par que, junto com os alunos, direcionou as atividades procurando dirimir eventuais dúvidas sobre as questões em estudo. 


\subsection{Métodos de registro dos dados}

Os dados obtidos a partir da realização da pesquisa constituem-se em:

Gravações de áudio das atividades de pequenos grupos realizadas nas etapas descritas nas Turmas A, B e C: as gravações subsidiaram a análise das interações discursivas dos alunos;

Questionários de caracterização aplicados nas Turmas A e C: as respostas aos questionários serviram de base para a formação de grupos heterogêneos;

As interações discursivas estabelecidas nos grupos cooperativos e colaborativos nas Turmas A, B e C foram analisadas em conjunto com base nas três dimensões propostas por Kumpulainen e Mutanen (1999). Para tanto, construímos mapas analíticos, nos moldes ilustrados no Quadro 4. Os mapas analíticos para todos os grupos são apresentados no CD-ROM, em anexo. Cabe lembrar que essa metodologia de análise de dados já foi utilizada em trabalhos anteriores de nossa autoria (TEODORO; CABRAL; QUEIROZ, 2015). Dessa forma, faremos a seguir uma breve exposição sobre a construção dos mapas, assim como abordaremos os desafios encontrados para torná-la consistente e coerente com os objetivos do trabalho.

No Quadro 4, apresentamos um trecho do mapa analítico da primeira atividade do grupo de base da Turma C, realizada pelo Grupo 1. No mapa analítico, temos duas unidades de análise: a primeira, chamada de unidade de mensagem, é referente a uma exposição verbal que possa representar uma mensagem, sendo que cada unidade de mensagem foi numerada e classificada na primeira dimensão (função de fala) e na segunda dimensão (processamento cognitivo); a segunda unidade é marcada por períodos de tempo determinados de 2 minutos, tendo sido classificada na terceira dimensão (processamento social). Os fragmentos proferidos pelo docente e pelos alunos de pós-graduação que o auxiliaram foram transcritos para as atividades jigsaw e PLTL, mas não foram classificados. Assim, o Quadro 4 exemplifica como o mapa foi construído para cada um dos grupos, permitindo a organização e a posterior análise dos dados. 
Quadro 4 - Trecho do mapa analítico das interações ocorridas na primeira atividade do Grupo 1 da Turma C. Exemplificação das unidades de análises que constituem o mapa.

\begin{tabular}{|c|c|c|c|c|}
\hline $\begin{array}{l}\text { Unidade } \\
\text { de } \\
\text { Mensagem }\end{array}$ & $\begin{array}{l}\text { Função } \\
\text { de fala }\end{array}$ & Fragmentos da transcrição & $\begin{array}{l}\text { Processo } \\
\text { Cognitivo }\end{array}$ & Agente \\
\hline 169 & Int & $\begin{array}{l}\text { Você concorda que se não dá para perceber a } \\
\text { mudança visualmente é porque está } \\
\text { ocorrendo lentamente? }\end{array}$ & PCE & A4 \\
\hline 170 & Cit-C & $\begin{array}{l}\text { Se estivesse acontecendo rapidamente, você } \\
\text { veria. }\end{array}$ & PCE & A4 \\
\hline 171 & Jul & Não. & PCR & A5 \\
\hline 172 & Cit-C & $\begin{array}{l}\text { Não é porque está acontecendo rápido ou } \\
\text { devagar, é porque está acontecendo ao } \\
\text { mesmo tempo. }\end{array}$ & PCE & A5 \\
\hline 173 & C-Res-C & $\begin{array}{l}\text { Por exemplo, ao mesmo tempo em que você } \\
\text { tem, vamos supor, rápido ou lento, o produto } \\
\text { formando o reagente, o reagente vai estar } \\
\text { formando o produto. }\end{array}$ & PCE & A5 \\
\hline 174 & C-Res-C & A concentração vai permanecer. & PCE & A1 \\
\hline 175 & C-Res & Vai ficar elas por elas. & PCR & A5 \\
\hline 176 & Cit-C & $\begin{array}{l}\text { Você vê só o produto e o reagente, você não } \\
\text { vê o caminho. }\end{array}$ & PCE & A1 \\
\hline 177 & Org-I & $\begin{array}{l}\text { Então, se no produto e no reagente, fica } \\
\text { sempre a mesma concentração, independente } \\
\text { da velocidade, você só vai ver a concentração. }\end{array}$ & PCE & A1 \\
\hline 178 & Jul & É. & PCR & A5 \\
\hline 179 & Inc & Pode ser rápido ou lento, mas... & & A5 \\
\hline 180 & Int & Onde é que você está? & PCR & A5 \\
\hline 181 & Org-A & Volta aí. & PCR & A1 \\
\hline 182 & Org-I & $\begin{array}{l}\text { No estabelecimento do equilíbrio químico, as } \\
\text { velocidades das reações diretas e inversas se } \\
\text { igualam, ou seja, as reações não cessam, } \\
\text { apesar de visualmente. }\end{array}$ & PCE & A1 \\
\hline 183 & Org-I & $\begin{array}{l}\text { As características do sistema permanecerão } \\
\text { as mesmas. }\end{array}$ & PCE & A5 \\
\hline 184 & Int & Não é? & PCR & A5 \\
\hline 185 & Int & Aparentarem, alguma coisa assim? & PCR & A1 \\
\hline 186 & Res & $\begin{array}{l}\text { Acho que nem é aparentarem, é a mesma } \\
\text { característica. }\end{array}$ & PCR & A5 \\
\hline 187 & Int & Não é? & PCR & A5 \\
\hline 188 & Res & $\begin{array}{l}\text { É que ele colocou aqui para ver como vamos } \\
\text { escrever. }\end{array}$ & PCR & A1 \\
\hline 189 & Org-I & $\begin{array}{l}\text { As reações não param, apesar de a gente, } \\
\text { olhando, parecer que elas pararam, que a } \\
\text { reação parou. }\end{array}$ & PCE & A1 \\
\hline 190 & Int & Hum? & PCR & A5 \\
\hline 191 & Int & Entendeu? & PCR & A1 \\
\hline 192 & $\begin{array}{l}\text { LVA } \\
\text { Res }\end{array}$ & $\begin{array}{l}\text { Ele colocou assim: apesar de visualmente } \\
\text { parecer que a reação para. }\end{array}$ & PCR & A1 \\
\hline Tempo & 14min & Processamento social: Colaborativo & & \\
\hline
\end{tabular}
Int = interrogação; Res= resposta; Res-C= resposta crítica; C-Res-C= complemento de resposta critica; Org-A= organização de ação; Org-I= organização de ideia; Ava= avaliação; LVA= leitura em voz alta; Jul= julgamento; Cit-C= citação crítica; Inc= Inclassificável; $P C R=$ processamento cognitivo rotineiro; $P C E=$ processamento cognitivo exploratório; $A X=$ Aluno $X$, sendo $X$ de 1 a 5

Cada mapa analítico foi construído separadamente por dois pesquisadores (autor desse trabalho e sua orientadora), que analisaram e classificaram cada mapa. 
Após a finalização dos mapas, os pesquisadores reuniram-se para verificar possíveis incoerências na classificação das unidades de mensagens. Juntos, os pesquisadores revisaram cada um dos mapas, dando uma classificação final para cada um deles. Esse procedimento fortaleceu a nossa análise, corrigindo possíveis incoerências e dando uma uniformidade aos dados discutidos.

A seguir, apresentaremos algumas considerações e premissas que subsidiaram a construção dos mapas.

Em relação às unidades de análise, destacamos que a divisão das exposições verbais em unidades de mensagem não foi feita considerando-se a estrutura gramatical ou a extensão da mensagem, mas sim a capacidade de transmitir com clareza uma das funções previamente definidas, sendo possível que uma exposição verbal faça referência a mais de uma função de fala ao mesmo tempo. Porém, optamos por fazer apenas uma classificação por unidade de mensagem. Sendo assim, decidimos que, na situação de dubiedade da função de fala, ela seria classificada com a função que melhor se encaixasse no conjunto e no direcionamento da atividade. Ou seja, a classificação das unidades foi feita dando-se ênfase à análise do meio e do momento em que foram proferidas.

No decorrer do desenvolvimento do mapa, deparamo-nos com determinados trechos impossíveis de serem classificados dentre as funções de fala estabelecidas, juntamente com outros que se apresentavam de forma incompleta. Em ambas as situações, definimos os referidos trechos como inclassificáveis e representados pela sigla "Inc".

Ressaltamos, ainda, que algumas das funções de fala definidas na primeira dimensão podem parecer confusas à primeira vista, cabendo aqui uma explanação sobre cada uma delas.

A função de fala do tipo "julgamento" pode ser confundida com a função do tipo "citação crítica" se não forem guardados os devidos cuidados. A primeira diz respeito ao ato de concordar ou discordar de forma direta e objetiva, sem apresentar argumentos favoráveis ou desfavoráveis frente a uma atitude ou ideia apresentada dentro da atividade. Já a função do tipo "citação crítica" pressupõe a concordância ou discordância em relação a uma ideia ou fato acontecido dentro do grupo, com a apresentação de uma explanação que baseie essa opinião. Dessa forma, o fator mais importante para a diferenciação dessas funções é a apresentação ou não de uma explanação com caráter crítico. Cabe lembrar que a citação crítica pode fazer 
referência ao conteúdo que está em discussão e também às ações demandadas dentro do grupo.

Cabe ressaltar a diferença entre a função de fala do tipo "julgamento" e a função de fala do tipo "avaliação". A primeira, como dito anteriormente, faz referência ao ato de concordar ou não com uma ideia ou ação. Já a segunda diz respeito ao ato de avaliar uma ação ou ideia apresentada por um aluno ou pelo grupo, atribuindo-Ihe uma qualificação positiva ou negativa.

Outra função que exige esclarecimento é a função do tipo "experiencial". Esta é caracterizada nos contextos nos quais o aluno se refere a uma situação vivenciada por ele ou pelo grupo, desde que ele se inclua na ação mencionada, como por exemplo: "Nós fizemos", "A gente já entregou". Esta função também pode fazer referência a uma característica ou habilidade própria que está sendo apresentada, como exemplo: "Eu sei", "Fui eu que fiz" ...

A função do tipo "leitura em voz alta" também exige esclarecimento, não pelo fato de poder ser confundida, mas sim por ser uma função que depende diretamente do conhecimento das ações que estão sendo realizadas dentro dos grupos. Entendemos que, quando um aluno faz uma leitura em voz alta, ele a faz com um objetivo que gera uma segunda função, como resposta a uma pergunta, elaboração de uma pergunta, organização do grupo ou simplesmente informação ao grupo. Dessa forma, esta função é a única que aceita uma segunda classificação.

Por fim, faz-se importante esclarecer a forma como usamos a função de fala do tipo "organização de ideia", que pode ser identificada em dois contextos, sendo facilmente confundida com a função de resposta direta ou crítica. A função "organização de ideia" faz-se presente quando o aluno tenta organizar ideias expressas anteriormente para formar uma resposta ou para melhorar uma resposta já formulada, assim como pode aparecer com o objetivo de sumarizar ideias expressas anteriormente. Já a função do tipo "resposta" faz referência direta a uma pergunta feita anteriormente. Mais uma vez, denotamos a importância de se verificar as funções não só pelas mensagens em si mesmas, mas também pelo contexto em que se encontram. 


\section{RESULTADOS E DISCUSSÃO}

Os dados discutidos neste capítulo compreendem aqueles coletados com o intuito de responder às seguintes questões de pesquisa:

- De que forma a natureza específica da disciplina pode influenciar na dinâmica das interações discursivas em grupo cooperativo jigsaw?

- De que forma a natureza específica da disciplina pode influenciar na dinâmica das interações discursivas em grupo colaborativo PLTL?

- De que forma o grau de estrutura da atividade de pequeno grupo pode interferir na dinâmica das interações discursivas em uma mesma disciplina?

Para tanto, analisamos as produções orais e escritas coletadas nas atividades de pequenos grupos realizadas nas Turmas $\mathrm{A}, \mathrm{B}$ e $\mathrm{C}$ e registradas em áudios.

Lançamos mão dos dados obtidos nas atividades dos grupos cooperativos jigsaw das Turmas A e C, nas disciplinas Comunicação e Expressão em Linguagem Científica I e Introdução à Química, respectivamente, para analisar em que medida a natureza específica da disciplina pode influenciar na dinâmica das interações dos alunos nos grupos cooperativos jigsaw. Para isso, classificamos as transcrições das falas de todos os participantes dos grupos de acordo com as três dimensões propostas por Kumpulainen e Mutanen (1999). De forma análoga e com propósitos semelhantes, utilizamos os dados obtidos nas atividades dos grupos colaborativos PLTL das Turmas B e C, nas disciplinas Cinética Química e Introdução à Química.

Para verificarmos de que forma o grau de estrutura da atividade de pequeno grupo pode interferir na dinâmica das interações discursivas, fizemos uso dos dados obtidos nas atividades dos grupos colaborativos PLTL e cooperativos jigsaw da Turma C. Estes também foram analisados com base nas três dimensões propostas por Kumpulainen e Mutanen (1999).

Por fim, a partir da análise de todos os dados produzidos, verificamos a viabilidade da utilização das atividades em pequenos grupos nas diferentes disciplinas do Ensino Superior de Química. Para tanto, analisamos as nuances das diferentes estratégias nas diferentes disciplinas, lembrando que a disciplina Comunicação e Expressão em Linguagem Científica I baseia-se em diferentes conhecimentos da linguagem verbal, escrita, leitura e interpretação de texto, a disciplina Introdução à Química baseia-se em um conjunto de conceitos, habilidades e procedimentos próprios da Química e a disciplina Cinética Química baseia-se em 
um conjunto de conceitos relativos a cálculos matemáticos, medidas e noções de estatística, envolvendo diferentes formas de pensar a Matemática articulada com os conhecimentos de Química. Esperamos, assim, alcançar a abrangência necessária para a construção dos nossos apontamentos finais.

\subsection{Influência da natureza das disciplinas na dinâmica das interações discursivas em grupo cooperativo jigsaw}

As interações discursivas estabelecidas nos grupos cooperativos jigsaw nas Turmas A e C foram analisadas com base em três dimensões: função de fala, processamento cognitivo e processamento social. Cada uma dessas funções será analisada a seguir separadamente.

\subsubsection{Análise das interações discursivas na perspectiva da primeira dimensão: função de fala}

Com o intuito de facilitar a análise das interações discursivas na perspectiva das funções de fala, estas foram distribuídas em três blocos.

O primeiro bloco é composto pelas funções de fala dos seguintes tipos: interrogação (Int), resposta (Res), complemento de resposta (C-Res), informação (Inf) e leitura em voz alta (LVA). Estas funções foram agrupadas por serem capazes de refletir as interações entre os alunos na busca direta e objetiva pela resolução da atividade proposta pelos professores.

O Quadro 5 apresenta trechos do mapa analítico da terceira atividade do Grupo 1 da Turma C, nos quais as funções de fala do primeiro bloco se fazem presentes.

Quadro 5 - Trechos do mapa analítico das interações ocorridas na terceira atividade do Grupo 1 da Turma C, exemplificando as funções de fala pertencentes ao primeiro bloco.

(continua)

\begin{tabular}{|c|c|l|c|c|}
\hline $\begin{array}{l}\text { Unidade de } \\
\text { Mensagem }\end{array}$ & $\begin{array}{c}\text { Função } \\
\text { de fala }\end{array}$ & \multicolumn{1}{|c|}{ Fragmento 1 } & $\begin{array}{c}\text { Processo } \\
\text { Cognitivo }\end{array}$ & Agente \\
\hline 94 & Int & A dois é do quê? De equilíbrio? & PCR & A5 \\
\hline 95 & Res & Solução tampão. & PCR & A2 \\
\hline
\end{tabular}


Quadro 5 - Trechos do mapa analítico das interações ocorridas na terceira atividade do Grupo 1 da Turma C, exemplificando as funções de fala pertencentes ao primeiro bloco.

(conclusão)

\begin{tabular}{|c|c|c|c|c|}
\hline $\begin{array}{c}\text { Unidade de } \\
\text { Mensagem }\end{array}$ & $\begin{array}{c}\text { Função } \\
\text { de fala }\end{array}$ & Fragmento 1 & $\begin{array}{c}\text { Processo } \\
\text { Cognitivo }\end{array}$ & Agente \\
\hline 96 & Inf & Solução também é equilíbrio. & PCR & A5 \\
\hline 97 & Inf & Ele desmembrou o tema equilíbrio. & PCR & A2 \\
\hline 99 & C-Res & É um ácido fraco com um sal. & PCR & A2 \\
\hline $\begin{array}{l}\text { Unidade de } \\
\text { Mensagem }\end{array}$ & $\begin{array}{c}\text { Função } \\
\text { de fala }\end{array}$ & Fragmento 2 & $\begin{array}{l}\text { Processo } \\
\text { Cognitivo }\end{array}$ & Agente \\
\hline 263 & LVA/lnt & $\begin{array}{l}\text { Solução tampão pode ser utilizada como } \\
\text { gatilho? }\end{array}$ & PCR & $\mathrm{A} 3$ \\
\hline 264 & Int & Cadê o Atkins? Será que tem algum aí? & PCR & $\mathrm{A} 2$ \\
\hline 265 & Res & É o capítulo doze, eu acho, que tem tampão. & PCR & $\mathrm{A} 2$ \\
\hline
\end{tabular}

O segundo bloco é composto pelas funções de fala dos seguintes tipos: organização de ação (Org-A), experiencial (Exp), julgamento (Jul), avaliação (Ava) e afetiva (Afe). Estas funções foram agrupadas por serem capazes de refletir as interações ocorridas entre os interlocutores na perspectiva de interação social. Elas são, entre as demais, as que melhor refletem a interação social ocorrida entre os alunos. É com elas que eles julgam, avaliam, organizam e até elogiam seus pares.

O Quadro 6 apresenta trechos do mapa analítico da primeira atividade do Grupo 1 da Turma A, nos quais as funções de fala do segundo bloco se fazem presentes.

Quadro 6 - Trechos do mapa analítico das interações ocorridas na primeira atividade do Grupo 1 da Turma A, exemplificando as funções de fala pertencentes ao segundo bloco.

\begin{tabular}{|c|c|l|c|c|}
\hline $\begin{array}{c}\text { Unidade } \\
\text { de } \\
\text { Mensagem }\end{array}$ & $\begin{array}{c}\text { Função } \\
\text { de fala }\end{array}$ & Fragmento 3 & $\begin{array}{c}\text { Processo } \\
\text { Cognitivo }\end{array}$ & Agente \\
\hline 457 & Afe & Calma, calma. & PCR & $\mathrm{A} 4$ \\
\hline 458 & Cit-C & $\begin{array}{l}\text { Não fala que tem que justificar, porque a gente se } \\
\text { familiariza. }\end{array}$ & PCR & $\mathrm{A} 3$ \\
\hline 459 & Jul & Não, esse não tem que justificar. & PCR & $\mathrm{A} 2$ \\
\hline 460 & Org-A & $\begin{array}{l}\text { Mesma coisa, não precisa justificar então a gente } \\
\text { não coloca nada. }\end{array}$ & PCR & $\mathrm{A} 2$ \\
\hline $\begin{array}{c}\text { Unidade } \\
\text { de } \\
\text { Mensagem }\end{array}$ & $\begin{array}{c}\text { Função } \\
\text { de fala }\end{array}$ & \multicolumn{1}{|c|}{ Fragmento 4 } & $\begin{array}{c}\text { Processo } \\
\text { Cognitivo }\end{array}$ & Agente \\
\hline $\begin{array}{c}522 \\
\text { Org-A }\end{array}$ & $\begin{array}{l}\text { Você me guia, eu escrevo. Então vai, começa de } \\
\text { novo. }\end{array}$ & PCR & $\mathrm{A} 4$ \\
\hline $\begin{array}{c}\text { Unidade } \\
\text { de } \\
\text { Mensagem }\end{array}$ & $\begin{array}{c}\text { Função } \\
\text { de fala }\end{array}$ & Agora eu esqueci. & PCR & $\mathrm{A} 2$ \\
\hline 738 & Org-A & Deixa eu ver. & $\begin{array}{c}\text { Processo } \\
\text { Cognitivo }\end{array}$ & Agente \\
\hline 739 & Ava & Está bom os dois. & PCR & A3 \\
\hline
\end{tabular}


O terceiro bloco é composto pelas funções de fala dos seguintes tipos: resposta crítica (Res-C), complemento de resposta crítica (C-Res-C), citação crítica (Cit-C) e organização de ideia (Org-I). Estas funções foram agrupadas por serem capazes de refletir as interações entre os alunos baseadas em exercício críticoreflexivo com demanda cognitiva complexa.

O Quadro 7 apresenta trechos do mapa analítico da primeira atividade do Grupo 2 da Turma C, nos quais as funções de fala do terceiro bloco se fazem presentes.

Quadro 7 - Trechos do mapa analítico das interações ocorridas na primeira atividade do Grupo 2 da Turma C, exemplificando as funções de fala pertencentes ao terceiro bloco.

\begin{tabular}{|c|c|c|c|c|}
\hline $\begin{array}{l}\text { Unidade } \\
\text { de } \\
\text { Mensagem }\end{array}$ & $\begin{array}{l}\text { Função } \\
\text { de fala }\end{array}$ & Fragmento 6 & $\begin{array}{l}\text { Processo } \\
\text { Cognitivo }\end{array}$ & Agente \\
\hline 54 & Res-C & $\begin{array}{l}\text { Tem a ver com os lados, se a reação é } \\
\text { endotérmica ou exotérmica. }\end{array}$ & PCE & A2 \\
\hline 55 & C-Res-C & $\begin{array}{l}\text { Primeiro tem que ver a reação para saber qual } \\
\text { lado vai ser endotérmico e qual vai ser } \\
\text { exotérmico. }\end{array}$ & PCE & A1 \\
\hline $\begin{array}{l}\text { Unidade } \\
\text { de } \\
\text { Mensagem }\end{array}$ & $\begin{array}{l}\text { Função } \\
\text { de fala }\end{array}$ & $\begin{array}{l}\text { Fragmento } 7 \\
\end{array}$ & $\begin{array}{l}\text { Processo } \\
\text { Cognitivo }\end{array}$ & Agente \\
\hline 100 & Res-C & $\begin{array}{l}\text { É como se o equilíbrio fosse por compensação } \\
\text { de lado. }\end{array}$ & PCE & $\mathrm{A} 2$ \\
\hline 101 & Org-I & $\begin{array}{l}\text { Se a gente acrescentar produto, vai tender a } \\
\text { formar reagente porque tem excesso de } \\
\text { produto, se colocarmos reagente, vai tender a } \\
\text { produto. }\end{array}$ & PCE & A1 \\
\hline $\begin{array}{l}\text { Unidade } \\
\text { de } \\
\text { Mensagem }\end{array}$ & $\begin{array}{l}\text { Função } \\
\text { de fala }\end{array}$ & Fragmento 8 & $\begin{array}{l}\text { Processo } \\
\text { Cognitivo }\end{array}$ & Agente \\
\hline 160 & C-Res-C & $\begin{array}{l}\text { Vai dar } \mathrm{Na}^{+}, \mathrm{Cl}^{-} \mathrm{H}_{3} \mathrm{O}^{+} \text {e } \mathrm{OH}^{-} \text {. Se eu coloco } \mathrm{Na}^{+} \text {, } \\
\text { eu vou ter ele no produto e no reagente. }\end{array}$ & PCE & A1 \\
\hline 161 & Cit-C & $\begin{array}{l}\text { Sim, mas é íon, não é na forma de sal. Isso é } \\
\text { um sal, não está íon. }\end{array}$ & PCE & $\mathrm{A} 2$ \\
\hline
\end{tabular}

No Quadro 8, apresentamos a frequência expressa em porcentagem em que cada função de fala foi utilizada nos grupos cooperativos jigsaw nas Turmas A e C, para cada bloco de análise. Nele apresentamos os dados obtidos para o Grupo $1 \mathrm{e}$ para o Grupo 2 da Turma A e para o Grupo 1 e para o Grupo 2 da Turma C. 
Quadro 8 - Distribuição das funções de fala para os grupos de base jigsaw na primeira e terceira atividades dos grupos da Turma A e da Turma C.

\begin{tabular}{|c|c|c|c|c|c|c|c|c|c|}
\hline & \multicolumn{4}{|c|}{ Turma A } & \multicolumn{4}{|c|}{ Turma C } \\
\hline & & \multicolumn{2}{|c|}{$\begin{array}{c}\text { Grupo } 1 \\
(\%)\end{array}$} & \multicolumn{2}{|c|}{$\begin{array}{c}\text { Grupo } 2 \\
(\%)\end{array}$} & \multicolumn{2}{|c|}{$\begin{array}{c}\text { Grupo } 1 \\
(\%)\end{array}$} & \multicolumn{2}{|c|}{$\begin{array}{c}\text { Grupo } 2 \\
(\%)\end{array}$} \\
\hline & & AT1 & AT3 & AT1 & AT3 & AT1 & AT3 & AT1 & AT3 \\
\hline \multirow{6}{*}{$\begin{array}{l}\text { o } \\
\frac{0}{0}\end{array}$} & Int & 27,9 & 27,4 & 29,5 & 29,7 & 21,8 & 21,5 & 17,0 & 20,4 \\
\hline & Res & 17,8 & 17,6 & 20,8 & 21,9 & 8,8 & 11,5 & 9,9 & 12,8 \\
\hline & C-Res & 7,0 & 10,5 & 5,5 & 8,3 & 1,0 & 2,6 & 9,3 & 2,3 \\
\hline & Inf & 8,1 & 6,8 & 8,4 & 5,7 & 1,8 & 9,6 & 12,2 & 3,3 \\
\hline & LVA & 2,7 & 1,4 & 1,1 & 2,1 & 3,6 & 3,0 & 5,1 & 4,3 \\
\hline & Soma & 63,5 & 63,7 & 65,3 & 67,7 & 37,0 & 48,2 & 53,5 & 43,1 \\
\hline \multirow{6}{*}{$\begin{array}{l}\mathcal{N} \\
\stackrel{\delta}{0} \\
\frac{o}{n}\end{array}$} & Org-A & 9,8 & 11,5 & 10,5 & 9,4 & 18,1 & 14,8 & 9,3 & 18,4 \\
\hline & Exp & 2,7 & 0,3 & 1,9 & 0 & 3,6 & 2,2 & 3,9 & 5,9 \\
\hline & Jul & 6,4 & 6,1 & 6,7 & 6,8 & 9,3 & 7,4 & 11,3 & 7,6 \\
\hline & Ava & 4,1 & 2,4 & 4,8 & 1,0 & 2,6 & 3,0 & 1,5 & 3,3 \\
\hline & Afe & 0,2 & 0,3 & 1,5 & 0 & 2,3 & 0,4 & 0,3 & 4,6 \\
\hline & Soma & 23,2 & 20,6 & 25,4 & 17,2 & 35,9 & 27,8 & 26,3 & 39,8 \\
\hline \multirow{5}{*}{$\begin{array}{c}m \\
\stackrel{0}{0} \\
\text { o }\end{array}$} & Cit-C & 7,0 & 8,4 & 5,0 & 5,7 & 5,2 & 10,4 & 3,0 & 3,6 \\
\hline & Org-I & 4,1 & 5,0 & 3,0 & 7,3 & 6,8 & 2,6 & 6,3 & 1,0 \\
\hline & Res-C & 2,2 & 1,0 & 1,3 & 2,1 & 5,2 & 4,4 & 3,2 & 3,9 \\
\hline & C-Res-C & 0 & 1,3 & 0 & 0 & 9,9 & 6,6 & 7,7 & 8,6 \\
\hline & Soma & 13,3 & 15,7 & 9,3 & 15,1 & 27,1 & 24 & 20,2 & 17,1 \\
\hline
\end{tabular}

Int = interrogação; Res= resposta; C-Res= complemento de resposta; Inf= informação; LVA= leitura em voz alta; Org- $A=$ organização de ação; $E x p=$ experencial; Jul= julgamento; Ava= avaliação; $A f e=$ afetiva; Cit-C= citação crítica; Org-I organização de ideia; Res-C= resposta crítica e C-Res-C= complemento de resposta crítica; AT1= primeira atividade e AT3= terceira atividade dos grupos de base jigsaw.

Analisamos as interações estabelecidas apenas nos grupos de base do jigsaw, nos quais foram realizadas a primeira e a terceira atividades, porque é nesse contexto que os alunos trabalham juntos em seus grupos heterogêneos de origem. Fato que não ocorre no grupo de especialistas, formado por membros diferentes, originários de distintos grupos de base.

Com relação às funções de fala que compõem o primeiro bloco (interrogação, resposta, complemento de resposta, informação e leitura em voz alta), nos dois grupos da Turma A encontramos somatória superior a $60,0 \%$ nos quatro encontros analisados, enquanto para os grupos da Turma $\mathrm{C}$, encontramos valores que variam de $37,0 \%$ a $53,5 \%$. O uso significativo dessas funções indica que os alunos se mantiveram dedicados à resolução das atividades em ambas as turmas. Por meio delas, eles fazem a leitura do material de referência e do material produzido durante a atividade, oferecem informações, questionam e respondem as perguntas lançadas ao grupo. Dessa forma, o resultado indica o comprometimento dos alunos em sua 
resolução. Algumas peculiaridades, no entanto, distinguem as interações estabelecidas em cada uma das turmas.

$\mathrm{Na}$ Turma A os alunos fazem acentuado uso das funções de fala dos tipos resposta direta e complemento de resposta direta, uso que se revela suficiente na busca pelas respostas para a atividade proposta: análise de documentos científicos de naturezas distintas e percepção das características inerentes a cada um. Já na Turma C, os alunos precisam responder questões sobre Equilíbrio Químico, conteúdo reconhecido como de grande complexidade e que gera problemas de aprendizagem (CAROBIN; SERRANO, 2007). Essa situação faz com que se engajem em discussões mais críticas, não sendo suficientes, assim, as respostas diretas, fato que justifica o uso em menor quantidade das funções do primeiro bloco pela Turma C. Paralelamente, o uso reduzido deste tipo de função de fala levará, como consequência, a um uso superior das funções do bloco 3 , como será mostrado e discutido a seguir.

O Quadro 9 apresenta trechos do mapa analítico da primeira atividade do Grupo 1 da Turma A e da primeira atividade do Grupo 1 da Turma C. Nele são apresentados dois fragmentos que evidenciam a forma como as funções de fala do bloco 1 se conectam na realização de atividades inerentes a cada uma das turmas e corroboram as afirmações anteriores. Com o objetivo de tornar mais rápida a identificação dos fragmentos nos quadros, passaremos a indicar os fragmentos pertencentes à Turma C com sombreamento cinza e os fragmentos da Turma A sem sombreamento.

Quadro 9 - Trechos do mapa analítico das interações ocorridas na primeira atividade do Grupo 1 da Turma A (Fragmento 9) e na primeira atividade do Grupo 1 da Turma C (Fragmento 10).

(continua)

\begin{tabular}{|c|c|l|c|}
\hline $\mathbf{N}^{\circ}$ & $\begin{array}{c}\text { Função } \\
\text { de fala }\end{array}$ & \multicolumn{1}{|c|}{ Fragmento 9 } & Agente \\
\hline 126 & Inf & $\begin{array}{l}\text { O meu (artigo) é (sobre) água do planeta terra. O meu é } \\
\text { educacional, artigo. }\end{array}$ & A2 \\
\hline 127 & Int & Da Química Nova também? & $\mathrm{A} 4$ \\
\hline 128 & Res & Isso, só que na área de educação. & $\mathrm{A} 2$ \\
\hline 129 & LVAlnf & O nome (artigo) é Águas do Planeta Terra. & $\mathrm{A} 2$ \\
\hline 130 & Int & Autor? & $\mathrm{A} 4$ \\
\hline 131 & $\mathbf{R e s}$ & O autor é Marcos Tadeu Graci. & $\mathrm{A} 2$ \\
\hline 132 & Inf & Só o meu que tem um nome de três linhas. & $\mathrm{A} 3$ \\
\hline 133 & Ava & É normal. & $\mathrm{A} 2$ \\
\hline 134 & Inf & O meu tem um autor de três linhas. & $\mathrm{A} 4$
\end{tabular}


Quadro 9 - Trechos do mapa analítico das interações ocorridas na primeira atividade do Grupo 1 da Turma A (Fragmento 9) e na primeira atividade do Grupo 1 da Turma C (Fragmento 10).

\begin{tabular}{|c|c|l|c|}
\hline $\mathbf{N}^{\circ}$ & $\begin{array}{c}\text { Função } \\
\text { de fala }\end{array}$ & \multicolumn{1}{|c|}{ Fragmento 10 } & Agente \\
\hline 581 & LVA/Int & $\begin{array}{l}\text { O equilíbrio químico da substância água pode ajudar a definir } \\
\text { ácidos, bases e pH? Se sim, indique como. }\end{array}$ & $\mathrm{A} 1$ \\
\hline 582 & Res & Sim. & $\mathrm{A} 5$ \\
\hline 583 & C-Res-C & A concentração em água pura de $\mathrm{H}^{+}$é de $10^{-7}$ e de $\mathrm{OH}^{-}$é 10-7 mol/L. & $\mathrm{A} 2$ \\
\hline 584 & Jul & Hum, não necessariamente. & $\mathrm{A} 5$ \\
\hline 585 & C-Res-C & Da água pura. & $\mathrm{A} 2$ \\
\hline 586 & Afe & Muito bem. & $\mathrm{A} 1$ \\
\hline 587 & C-Res-C & $\begin{array}{l}\text { E esse pode ajudar a definir o pH porque há adição de uma } \\
\text { substância ácida. Aumenta a concentração de } \mathrm{H}^{+} \text {e diminui o pH. }\end{array}$ & $\mathrm{A} 2$ \\
\hline 588 & C-Res-C & $\begin{array}{l}\text { Porque o produto é o mesmo. } \\
\text { Jul do OH mais o pH tem que dar } 14 .\end{array}$ & $\mathrm{A} 2$ \\
\hline 589 & Jul & Eu concordo. & $\mathrm{A} 4$ \\
\hline
\end{tabular}

O fragmento 9 do Quadro 9 ilustra como três alunos usam uma informação inicial para direcionar a interrogação, que vai gerar uma resposta direta e, assim, de forma subsequente, as funções se repetem levando à resolução da atividade a partir da identificação ou recordação de informações disponíveis no material didático fornecido na disciplina. Já no fragmento 10, quatro alunos buscam a resposta da atividade começando por uma leitura em voz alta, que gera, simultaneamente, uma interrogação. Esta foi seguida por uma resposta direta que, não suficiente para atender ao que a atividade pede, levou os alunos à realização de um exercício crítico-reflexivo baseado no uso das funções complemento de resposta crítica e julgamento.

Fragmentos como os citados no Quadro 9, onde constam funções de fala do bloco 1, repetiram-se diversas vezes na condução da atividade em cada turma. Assim, é possível afirmar que as características próprias das disciplinas, principalmente associadas ao conteúdo que veiculam, influenciaram nas interações discursivas nos grupos e acabaram gerando um procedimento particular de trabalho em cada uma delas.

Em contraponto, outro aspecto comum observado com relação às funções de fala nas duas turmas consiste no fato de muitas perguntas formuladas no decorrer das atividades encontrarem mais do que uma resposta. O que corrobora a afirmação sobre o comprometimento e dedicação dos alunos na resolução das atividades, busca pela melhor resposta e responsabilidade individual no seu desenvolvimento. 
O Quadro 10 apresenta trechos do mapa analítico da primeira atividade do Grupo 1 da Turma A e da primeira atividade do Grupo 1 da Turma C de modo a evidenciar como se deu a construção de respostas dessa forma. A partir da leitura dos trechos é possível constatar novamente como as respostas são dadas de uma forma mais direta e objetiva na Turma A, enquanto na Turma C as respostas são dadas de uma forma mais crítica.

Quadro 10 - Trechos do mapa analítico das interações ocorridas na primeira atividade do Grupo 1 da Turma A (Fragmento 11) e na primeira atividade do Grupo 1 da Turma C (Fragmento 12).

\begin{tabular}{|c|c|c|c|}
\hline $\mathbf{N}^{\circ}$ & $\begin{array}{l}\text { Função } \\
\text { de fala }\end{array}$ & Fragmento 11 & Agente \\
\hline 778 & LVA/Res & $\begin{array}{l}\text { Concluímos que há várias formas de transmitir o conhecimento } \\
\text { através de. }\end{array}$ & A4 \\
\hline 779 & Int & Como é que você tinha falado? & A4 \\
\hline 780 & Res & De redigir artigos, agora vai identificar. & A2 \\
\hline 781 & C-Res & Não é só artigo, dá para colocar textos científicos. & A1 \\
\hline 782 & C-Res & Teses, textos e artigos. & A4 \\
\hline $\mathbf{N}^{\circ}$ & $\begin{array}{c}\text { Função } \\
\text { de fala }\end{array}$ & Fragmento 12 & Agente \\
\hline 330 & Int & Como é que começava a primeira parte mesmo? & A5 \\
\hline 331 & Res & É a parte um e a parte dois. A um é alteração da concentração. & A5 \\
\hline 332 & Res-C & A temperatura muda a constante. & A3 \\
\hline 333 & Jul & Sim. & A5 \\
\hline 334 & C-Res-C & A concentração não altera e a temperatura altera. & A1 \\
\hline 335 & C-Res-C & Tem até o gráfico. & A3 \\
\hline 336 & C-Res-C & Exponencial, que está aumentando a constante com a temperatura. & A1 \\
\hline
\end{tabular}

No fragmento 11 a resposta dada pelo aluno A2 é complementada de forma direta pelos alunos A1 e A4. Nele pode-se verificar que os complementos feitos levam os alunos a uma conclusão satisfatória, que encerra a resposta à pergunta. Paralelamente, no fragmento 12, a resposta é construída simultaneamente pelos alunos A1, A3 e A5. Entretanto, só a primeira parte da resposta dada pelo aluno A5 é direta, e todos os complementos são dados de forma crítica, o que acaba levando os alunos a uma análise mais aprofundada sobre a temática.

Conforme ilustra o Quadro 8, para as funções de fala que compõem o segundo bloco (organização de ação, experiencial, julgamento, avaliação e afetiva), nos grupos da Turma A a somatória apresentou valores de 23,2\% e 20,6\% para as atividades do Grupo 1 e somatórias de 25,4\% e 17,7\% para as atividades do Grupo 2. Para os grupos da Turma C, encontramos somatória de $35,9 \%$ e $27,8 \%$ para as atividades do Grupo 1 e somatória de $26,3 \%$ e 39,8\% para as atividades do Grupo 2. 
Percebe-se que os valores encontrados para as atividades da Turma $C$ foram superiores aos encontrados para a Turma $A$, sugerindo que na Turma $C$ os alunos sentiram uma necessidade maior em organizar e julgar o trabalho dos seus pares. De fato, as três maiores porcentagens de ocorrência no que diz respeito à função organização de ação foram localizadas na Turma C (18,1\%; 18,4\% e 14,8\%), enquanto o maior valor encontrado para Turma A foi de 11,5\%. De forma semelhante, todas as maiores porcentagens de ocorrência no que diz respeito à função julgamento também foram encontradas na Turma C, com valores entre 7,4\% e $11,3 \%$, enquanto o maior valor encontrado para Turma A foi de $6,8 \%$.

O Quadro 11 apresenta trechos do mapa analítico da primeira atividade do Grupo 2 da Turma A e da primeira atividade do Grupo 1 da Turma C. Nele são apresentados os fragmentos 13 e 14, que evidenciam a forma como as funções de fala do segundo grupo são usadas na condução da atividade e na interação entre os alunos de cada grupo de forma distinta.

Quadro 11 - Trechos do mapa analítico das interações ocorridas na primeira atividade do Grupo 2 da Turma A (Fragmento 13) e na primeira atividade do Grupo 1 da Turma C (Fragmento 14).

\begin{tabular}{|c|c|l|c|}
\hline $\mathbf{N}^{\circ}$ & $\begin{array}{c}\text { Função } \\
\text { de fala }\end{array}$ & \multicolumn{1}{|c|}{ Fragmento 13 } & Agente \\
\hline 129 & Afe & Olha a carinha dela. & $\mathrm{A} 1$ \\
\hline 130 & Org-I & Eu estou fazendo meio conciso, se colocar tudo vai dar muita coisa. & $\mathrm{A} 5$ \\
\hline 131 & Jul & Eu também. & $\mathrm{A} 1$ \\
\hline 132 & Ava & Melhor para ela. & $\mathrm{A} 5$ \\
\hline 133 & Exp & Eu sou meio assim, não gosto de escrever muito bla, bla, bla. & $\mathrm{A} 5$ \\
\hline 134 & Jul & Beleza. & $\mathrm{A} 2$ \\
\hline 135 & $\mathbf{A f e}$ & Depois é ela que vai escrever. & $\mathrm{A} 2$ \\
\hline 136 & Org-A & Se você quiser que eu escreva mais, aí você que vê se quer & $\mathrm{A} 5$ \\
\hline 137 & Exp & Acho que não. & $\mathrm{A} 3$ \\
\hline $\mathbf{N}^{\circ}$ & $\begin{array}{c}\text { Função } \\
\text { de fala }\end{array}$ & & $\mathrm{Agente}$ \\
\hline 321 & Org-A & Voltando. & $\mathrm{A} 1$ \\
\hline 322 & Org-A & Volta, volta. & $\mathrm{A} 4$ \\
\hline 323 & Org-A & Foca. & $\mathrm{A} 2$ \\
\hline 324 & Org-A & Gente, ajuda, poxa, deixa eu ver o que você está escrevendo. & $\mathrm{A} 1$ \\
\hline 325 & Exp & Eu estou escrevendo parte desse, para ficar mais rápido. & $\mathrm{A} 4$ \\
\hline 326 & Jul & Sim, é verdade. & $\mathrm{A} 1$ \\
\hline
\end{tabular}

No fragmento 13 percebemos como as funções de fala intermediam a interação dos alunos do Grupo 2 da Turma A. Destacamos a forma carinhosa como um dos alunos se dirige a outro: Aluno A1: Olha a carinha dela. Nessa exposição, a 
afetividade fica evidente, fato que não ocorre na segunda vez que essa função aparece (Aluno A2: Depois é ela que vai escrever). Nessa frase, a função afetiva não tem conotação tão direta, mas com o auxílio do áudio, percebe-se que o aluno demostrou de forma carinhosa uma preocupação com o fato de o outro membro do grupo ter que escrever demais na hora de transcrever o texto por eles produzido. De forma semelhante, vemos as funções do tipo experiencial e avaliação sendo usadas.

Paralelamente, o fragmento 14, retirado da atividade 1 do Grupo 1 da Turma C, demonstra como a interação entre os alunos ocorre de forma sistemática e direcionada. Nela, os três alunos participantes fazem uso da função de organização de ação para chamar a atenção e orientar o grupo na direção da postura correta para a boa prática da atividade. A função experiencial neste fragmento é usada pelo aluno A4 atrelada à própria atividade (Aluno A4: Eu estou escrevendo parte desse, para ficar mais rápido), diferentemente do observado para o aluno A5 no fragmento 13.

O fato da diferença observada na dinâmica das interações entre os alunos das duas turmas ser fruto, principalmente, do uso das funções do tipo organização de ação e julgamento corrobora as constatações alcançadas a partir da análise das funções de fala do primeiro bloco. Com efeito, os dois grupos da Turma A se engajaram em discussões que exigiram o uso preponderante de respostas diretas, atenuando a necessidade de iniciativas voltadas a tais funções. Em perspectiva contrária, os alunos da Turma $\mathrm{C}$, envolvidos de forma mais vigorosa na elaboração de respostas e complementos de resposta crítica, foram impulsionados a organizar ações e fazer apontamentos para atender às demandas da disciplina.

O Quadro 12 apresenta trechos do mapa analítico da primeira atividade do Grupo 1 da Turma C. Nele é apresentado o fragmento 15, que evidencia o uso das funções de fala organização de ação e julgamento diretamente entrelaçadas às funções de fala respostas e complementos de resposta crítica e citação crítica.

Quadro 12 - Trechos do mapa analítico das interações ocorridas na primeira atividade do Grupo 1 da Turma C (Fragmento 15).

\begin{tabular}{|l|c|lc|c|}
\hline $\mathbf{N}^{\circ}$ & $\begin{array}{c}\text { Função } \\
\text { de fala }\end{array}$ & Fragmento 15 & Agente \\
\hline 359 & Int & O que você está escrevendo? & A1 \\
\hline 360 & Org-A & Lê aí. & A1 \\
\hline 361 & LVARes & Considerando a concentração de produtos e reagentes. & A3
\end{tabular}


Quadro 12 - Trechos do mapa analítico das interações ocorridas na primeira atividade do Grupo 1 da Turma C (Fragmento 15).

(conclusão)

\begin{tabular}{|l|c|l|c|}
\hline $\mathbf{N}^{\circ}$ & $\begin{array}{c}\text { Função } \\
\text { de fala }\end{array}$ & \multicolumn{1}{|c|}{ Fragmento 15 } & Agente \\
\hline 362 & Org-A & Não esquece de escrever seu nome depois. & $\mathrm{A} 2$ \\
\hline 363 & Jul & E. & $\mathrm{A} 3$ \\
\hline 364 & C-Res-C & $\begin{array}{l}\text { As demais concentrações sejam alteradas, porém, a constante } \\
\text { permanece inalterada. }\end{array}$ & $\mathrm{A} 4$ \\
\hline 365 & C-Res-C & Agora, a temperatura interfere no valor da constante de equilíbrio... & $\mathrm{A} 3$ \\
\hline 367 & C-Res-C & A temperatura favorece as reações endotérmicas. & $\mathrm{A} 3$ \\
\hline 368 & Int & É só isso? & $\mathrm{A} 1$ \\
\hline 369 & Int & O que mais? & $\mathrm{A} 3$ \\
\hline 370 & Res & Não sei. & $\mathrm{A} 1$ \\
\hline 371 & Org-A & Qualquer opinião é bem-vinda. & $\mathrm{A} 3$ \\
\hline 372 & Exp & Não sei. & $\mathrm{A} 1$ \\
\hline 373 & Ava & Agora está bom. & $\mathrm{A} 2$ \\
\hline 374 & Inf & Não precisa ter tudo. & $\mathrm{A} 1$ \\
\hline 375 & Jul & E. & $\mathrm{A} 5$ \\
\hline 376 & Ava & Está bom, mas... & $\mathrm{A} 1$ \\
\hline 377 & Cit-C & $\begin{array}{l}\text { Mas é porque não vai tudo aí, é um resumo, é só as ideias mais } \\
\text { importantes. }\end{array}$ & $\mathrm{A} 1$ \\
\hline
\end{tabular}

O fragmento 15 revela que, em uma mesma passagem, os alunos do grupo trabalham com o tema Equilíbrio Químico, revezando-se entre organizar, julgar e avaliar as respostas dadas à questão proposta e, mesmo com toda essa interação na busca pela resposta, eles fecham o trecho questionando se a resposta dada seria suficiente para a atividade proposta. Esse fragmento assemelha-se a outros encontrados no decorrer das atividades realizadas na Turma C e reforça a influência da natureza específica da disciplina na dinâmica das interações discursivas desencadeadas em sala de aula.

Os resultados também mostram que para a função de fala do tipo afetiva foram encontrados resultados pouco expressivos e semelhantes para as duas turmas. De fato, cinco dentre os oito valores observados nas duas turmas indicam o uso dessa função em menos de $1 \%(0,2 \%$ e $0,3 \%$ na Turma $A ; 0,4 \%$ e $0,3 \%$ na Turma C). Para a função de fala do tipo avaliação encontramos valores entre 1,0\% e 4,8\% para a Turma A e valores entre 1,5\% e 3,3\% para a Turma C. Aparentemente, não existe uma tendência que possa ser destacada com relação a esta função, seja com relação às interações dentro das próprias turmas, seja entre a Turma $A$ e a Turma C. 
O uso dessas funções, mesmo de forma comedida no caso da função do tipo afetiva, indica que os alunos encontraram um ambiente social e seguro nas atividades realizadas nas duas turmas e se sentiram à vontade para demonstrar afeto, não se omitindo frente ao trabalho realizado pelos seus colegas de grupo, avaliando as suas ideias e ações.

O Quadro 13 apresenta trechos do mapa analítico da terceira atividade do Grupo 2 da Turma C e da primeira atividade do Grupo 2 da Turma A. Nele observase como as funções de fala afetiva e avaliação sugerem o ambiente social favorável e seguro como descrito acima.

Quadro 13 - Trechos do mapa analítico das interações ocorridas na terceira atividade do Grupo 2 da Turma C (Fragmento 16) e na primeira atividade do Grupo 2 da Turma A (Fragmento 17).

\begin{tabular}{|c|c|l|c|}
\hline $\mathbf{N}^{\circ}$ & $\begin{array}{c}\text { Função } \\
\text { de fala }\end{array}$ & \multicolumn{1}{|c|}{ Fragmento 16 } & Agente \\
\hline 170 & Ava & Simples assim. & A2 \\
\hline 171 & Afe & Já se empolga. & A3 \\
\hline 172 & Org-A & Vai, Juju. $\quad$ Fragmento 17 & A3 \\
\hline 173 & Afe & Juju está triste. & A1 \\
\hline $\mathbf{N}^{\circ}$ & $\begin{array}{c}\text { Função } \\
\text { de fala }\end{array}$ & & Agente \\
\hline 264 & Ava & Legal todo mundo feliz. & A1 \\
\hline 265 & Jul & Eu também achei. & A4 \\
\hline 266 & Ava & Nota dez para todo mundo. & A2 \\
\hline 267 & Afe & Só coitada da redatora. & A1 \\
\hline
\end{tabular}

Conforme ilustra o Quadro 8, para as funções de fala que compõem o terceiro bloco (organização de ideia, citação crítica, resposta crítica e complemento de resposta crítica) a somatória dessas funções nos grupos da Turma A apresentou valores de 13,3\% e 15,7\% para as atividades do Grupo 1 e somatórias de 9,3\% e $15,1 \%$ para as atividades do Grupo 2. Já para os grupos da Turma C, encontramos somatória de $27,1 \%$ e $24,0 \%$ para as atividades do Grupo 1 e somatória de $20,2 \%$ e $17,1 \%$ para as atividades do Grupo 2 .

Os valores encontrados para os dois grupos da Turma $C$ foram superiores aos encontrados para os dois grupos da Turma A, o que sugere que os alunos da Turma C participaram de atividades que exigiram respostas mais críticas e reflexivas. De fato, todas as maiores porcentagens referentes à função de resposta crítica foram aí localizadas (valores entre $3,2 \%$ e $5,2 \%$ ), e todas as maiores porcentagens de ocorrência no que diz respeito à função complemento de resposta 
crítica também foram aí encontradas (valores entre 6,6\% e 9,9\%). Os resultados para essas duas funções foram determinantes para os valores mais elevados encontrados para este bloco de análise para a Turma C.

O Quadro 14 apresenta trechos do mapa analítico da primeira atividade do Grupo 1 da Turma C e da primeira atividade do Grupo 2 da Turma A. Nele são apresentados os fragmentos 18 e 19, que evidenciam a forma como as funções de fala do terceiro bloco são usadas em cada um dos grupos.

Quadro 14 - Trechos do mapa analítico das interações ocorridas na primeira atividade do Grupo 1 da Turma C (Fragmento 18) e na primeira atividade do Grupo 2 da Turma A (Fragmento 19).

\begin{tabular}{|l|c|l|c|}
\hline $\mathbf{N}^{\circ}$ & $\begin{array}{c}\text { Função } \\
\text { de fala }\end{array}$ & \multicolumn{1}{|c|}{ Fragmento 18 } & Agente \\
\hline 61 & LVAInt & O que você entende por natureza dinâmica do equilíbrio químico? & $\mathrm{A} 3$ \\
\hline 69 & Res-C & É que no equilíbrio as reações continuam ocorrendo. & $\mathrm{A} 2$ \\
\hline 70 & Int & Você? & $\mathrm{A} 1$ \\
\hline 71 & Res-C & As velocidades das reações se igualam, elas ficam iguais. & $\mathrm{A} 3$ \\
\hline 72 & Jul & Isso aí. & $\mathrm{A} 4$ \\
\hline 73 & Exp & Não tem mais o que falar, eu acho. & $\mathrm{A} 5$ \\
\hline 77 & Res-C & $\begin{array}{l}\text { Apesar de o processo parecer parado visualmente, ele ainda está } \\
\text { ocorrendo molecularmente. }\end{array}$ & $\mathrm{A} 1$ \\
\hline $\mathbf{N}^{\circ}$ & $\begin{array}{c}\text { Função } \\
\text { de fala }\end{array}$ & & Fragmento 19 \\
\hline 25 & Int & $\begin{array}{l}\text { Alguém de vocês já tinha familiaridade sem ser a (revista) } \\
\text { Superinteressante? }\end{array}$ & $\mathrm{A} 5$ \\
\hline 26 & Res & Não. & $\mathrm{A} 3$ \\
\hline 27 & Res & Eu também não. & $\mathrm{A} 2$ \\
\hline
\end{tabular}

No fragmento 18 percebemos como os alunos do Grupo 1 da Turma C são levados pela pergunta a formular duas respostas sobre a temática Equilíbrio Químico. Nele, observamos que as respostas dadas são baseadas em conhecimento adquiridos em ocasiões anteriores. Esse embasamento teórico faz com que tanto as respostas dadas, quanto o seu complemento, sejam críticos. Ademais, a formulação das respostas acaba por exigir que os alunos coloquem em prática a habilidade de entender a química que ocorre em nível molecular ou exploratório (nível submiscroscópico, segundo Johnstone (1982)), conforme indica a resposta do Aluno A1: Apesar de o processo parecer parado visualmente, ele ainda está ocorrendo molecularmente. Ou seja, nessa unidade de mensagem, o aluno A1 procura explicar o fenômeno químico não só no plano macroscópico, mas também buscando a sua compreensão em um nível que requer maior capacidade de abstração, como é o caso do nível submicroscópico (JOHNSTONE, 1982). 
Em contraponto, no fragmento 19, referente à primeira atividade do Grupo 2 da Turma A, verificamos que a pergunta feita pelo aluno A5 também leva os alunos a duas respostas, mas, diferentemente do que se verifica no fragmento 16 , elas são diretas e não requerem embasamento teórico ou capacidade de abstração.

O Quadro 15 apresenta trechos do mapa analítico da primeira atividade do Grupo 2 da Turma A e da terceira atividade do Grupo 1 da Turma C. Nele são apresentados os fragmentos 20 e 21, que evidenciam a forma como a função de fala citação crítica é usada de forma distinta nas duas turmas.

Quadro 15 - Trechos do mapa analítico das interações ocorridas na primeira atividade do Grupo 2 da Turma A (Fragmento 20) e na terceira atividade do Grupo 1 da Turma C (Fragmento 21).

\begin{tabular}{|c|c|c|c|}
\hline $\mathbf{N}^{\circ}$ & $\begin{array}{l}\text { Função } \\
\text { de fala }\end{array}$ & Fragmento 20 & Agente \\
\hline 25 & Int & $\begin{array}{l}\text { Alguém de vocês já tinha familiaridade sem ser a (revista) } \\
\text { Superinteressante? }\end{array}$ & A5 \\
\hline 36 & Cit-C & $\begin{array}{l}\text { Acho que se lê não dá para entender porque nós ainda não temos } \\
\text { conhecimento para usar a tese. }\end{array}$ & A4 \\
\hline 37 & Cit-C & Até dá para entender, mas chega uma hora você viaja. & A2 \\
\hline 38 & Cit-C & É que a Superinteressante é feita para um público mais leigo. & A5 \\
\hline $\mathbf{N}^{\circ}$ & $\begin{array}{l}\text { Função } \\
\text { de fala }\end{array}$ & Fragmento 21 & Agente \\
\hline 272 & C-Res-C & $\begin{array}{l}\text { Solução tampão sempre tem um ponto crítico. Quando chega nele, } \\
\text { ela reverte a situação. }\end{array}$ & A6 \\
\hline 273 & Cit-C & $\begin{array}{l}\text { Não precisa ser necessariamente um tampão. Porque solução } \\
\text { tampão é aquela que o pH não muda muito. }\end{array}$ & A2 \\
\hline 274 & C-Res-C & Estabiliza o pH. & A4 \\
\hline 275 & Cit-C & $\begin{array}{l}\text { Ele deixa em equilíbrio em um determinado intervalo. Então, tem um } \\
\text { intervalo crítico. }\end{array}$ & A6 \\
\hline
\end{tabular}

Nos grupos da Turma A a função citação crítica normalmente apresenta uma análise crítica do ponto de vista pessoal do aluno sobre o material estudado, como se observa no fragmento 20 (A2: Até dá para entender, mas chega uma hora que você viaja). Já na Turma $C$, a citação crítica apresenta um embasamento teórico substancial, que exige do aluno uma demanda cognitiva maior, como exemplificado no fragmento 21 (A2: Não precisa ser necessariamente um tampão. Porque solução tampão é aquela que o pH não muda muito).

Cabe ainda relembrar que o uso da função citação crítica pode se apresentar de diferentes maneiras. No caso do fragmento 21 ela é assim considerada pois a explanação dos alunos busca fornecer elementos que permitam o aprofundamento da análise sobre a temática, apresentando recursos sobre o conteúdo em pauta que aprofundam a discussão a um nível superior ao apresentado anteriormente. 
O Quadro 16 apresenta trechos do mapa analítico da primeira e da terceira atividade dos Grupos 1 e 2 da Turma A e trechos do mapa analítico da primeira atividade dos Grupos 1 e 2 da Turma C. Nele são apresentados os fragmentos de 22 a 25 , que mostram distintas formas de uso da função de fala do tipo organização de ideia.

Quadro 16 - Trechos do mapa analítico das interações ocorridas na primeira atividade do Grupo 1 e terceira atividade do Grupo 2 da Turma A (Fragmentos 22 e 23), e na primeira atividade do Grupo 1 e do Grupo 2 da Turma C (Fragmentos 24 e 25).

\begin{tabular}{|c|c|c|c|}
\hline $\mathbf{N}^{\circ}$ & $\begin{array}{l}\text { Função } \\
\text { de fala }\end{array}$ & Fragmento 22 & Agente \\
\hline 293 & Org-I & Coloca aí o de Tese de Doutorado, para dar uma justificadinha. & A5 \\
\hline 294 & Org-I & Coloca: a Tese é direcionada para um espaço científico. & A4 \\
\hline $\mathbf{N}^{\circ}$ & $\begin{array}{l}\text { Função } \\
\text { de fala }\end{array}$ & $\begin{array}{ll}\text { Fragmento } 23 \\
\end{array}$ & Agente \\
\hline 58 & Org-I & Depois o item sobre a linguagem. & A4 \\
\hline 59 & Org-I & O que tem aqui, que não tem aí e o principal meio de acesso. & A2 \\
\hline $\mathbf{N}^{\circ}$ & $\begin{array}{l}\text { Função } \\
\text { de fala }\end{array}$ & Fragmento 24 & Agente \\
\hline 431 & Org-I & $\begin{array}{l}\text { A gente falou para considerar uma reação, considerando uma } \\
\text { endotérmica, a direta endotérmica e a inversa exotérmica. Aí, } \\
\text { trabalhávamos em cima dessa reação. }\end{array}$ & A1 \\
\hline 432 & Exp & Acho que era isso. & A1 \\
\hline 433 & Org-I & $\begin{array}{l}\text { Aí entra o que ele falou. Ela é endotérmica, aumenta a temperatura, } \\
\text { favorece a direta e a diminuição favorece a inversa. }\end{array}$ & A1 \\
\hline $\mathbf{N}^{\circ}$ & $\begin{array}{l}\text { Função } \\
\text { de fala }\end{array}$ & Fragmento 25 & Agente \\
\hline 100 & Res-C & É como se o equilíbrio fosse por compensação de lado. & A2 \\
\hline 101 & Org-I & $\begin{array}{l}\text { Se a gente acrescentar produto, vai tender a formar reagente porque } \\
\text { tem excesso de produto, se colocarmos reagente, vai tender a } \\
\text { produto. }\end{array}$ & A1 \\
\hline 102 & Jul & Isso. & A4 \\
\hline 103 & Org-I & $\begin{array}{l}\text { Mas se for o contrário, se tirarmos produto, vai favorecer produto, } \\
\text { porque ele vai faltar no equilíbrio. }\end{array}$ & A1 \\
\hline
\end{tabular}

Os fragmentos 22, 23 e 24 mostram como os alunos das duas turmas usam a função de organização de ideia para aprimorar a resposta do grupo, somando informações e perspectivas de análise. Para tanto, eles comentam e apresentam ideias frente à questão proposta. No fragmento 25 , no entanto, observamos que essa função é usada na Turma C com o objetivo de sumarizar as ideias desenvolvidas anteriormente (A1: Se a gente acrescentar produto, vai tender a formar reagente porque tem excesso de produto, se colocarmos reagente, vai tender a produto; A1: Mas se for o contrário, se tirarmos produto, vai favorecer produto, porque ele vai faltar no equilíbrio). Isso acontece porque, frente a uma análise 
aprofundada e com muitas contribuições teóricas, o grupo sente a necessidade de fazer uma síntese do que foi dito para finalizar a resposta, fato que não ocorre com a mesma frequência na Turma $A$.

\subsubsection{Análise das interações discursivas na perspectiva da segunda dimensão: processamento cognitivo}

A análise das interações discursivas permitiu a identificação dos três tipos de processamentos cognitivos: rotineiro, off-task e exploratório. O primeiro está relacionado a períodos em que os alunos concentram seus esforços na realização de atividades rotineiras que exigem apenas a manipulação, organização e execução, sem análise reflexiva. O segundo está relacionado a períodos nos quais os alunos direcionam sua interação para atividades que estão fora do contexto da tarefa solicitada pelo professor. O terceiro está relacionado a períodos em que os alunos concentram seus esforços na realização de atividades críticas e exploratórias, que podem incluir planejamento, levantamento de hipóteses, julgamento, avaliação e experimentação.

O Quadro 17 apresenta trechos dos mapas analíticos referentes à realização da primeira atividade do Grupo 1 da Turma C. Nele constam os três tipos de processamento cognitivo.

Quadro 17 - Trechos do mapa analítico das interações ocorridas na primeira atividade do Grupo 1 da Turma C, exemplificando os processamentos cognitivos: Rotineiro (Fragmento 26), Offtask (Fragmento 27), Exploratório (Fragmento 28)

(continua)

\begin{tabular}{|c|c|l|c|c|}
\hline $\mathbf{N}^{\circ}$ & $\begin{array}{c}\text { Função } \\
\text { de fala }\end{array}$ & \multicolumn{1}{|c|}{ Fragmento 26 } & $\begin{array}{c}\text { Processo } \\
\text { Cognitivo }\end{array}$ & Agente \\
\hline 11 & Org-A & Vai, vamos escrever. & PCR & A1 \\
\hline 12 & Org-A & Precisa pôr o nome do pessoal. & PCR & A4 \\
\hline 13 & Int & Nome? & PCR & A1 \\
\hline 14 & Res & Sim. & PCR & A4 \\
\hline $\mathbf{N}^{\circ}$ & $\begin{array}{c}\text { Função } \\
\text { de fala }\end{array}$ & \multicolumn{1}{c|}{ Fragmento 27 } & $\begin{array}{l}\text { Processo } \\
\text { Cognitivo }\end{array}$ & Agente \\
\hline 28 & & Vou brincar de código Morse. & PCO & A1 \\
\hline 29 & & Morse? & PCO & A2 \\
\hline 30 & & Falar em código. & PCO & A3 \\
\hline 31 & & $\begin{array}{l}\text { É, está bom. Nossa, está irritado. Tem alguma coisa } \\
\text { no meu olho? }\end{array}$ & PCo & A1 \\
\hline
\end{tabular}


Quadro 17 - Trechos do mapa analítico das interações ocorridas na primeira atividade do Grupo 1 da Turma C, exemplificando os processamentos cognitivos: Rotineiro (Fragmento 26), Offtask (Fragmento 27), Exploratório (Fragmento 28)

(conclusão)

\begin{tabular}{|c|c|l|c|c|}
\hline $\mathbf{N}^{\circ}$ & $\begin{array}{c}\text { Função } \\
\text { de fala }\end{array}$ & \multicolumn{1}{|c|}{ Fragmento 28 } & $\begin{array}{c}\text { Processo } \\
\text { Cognitivo }\end{array}$ & Agente \\
\hline 154 & Int & $\begin{array}{l}\text { Por que quando você tem um equilíbrio, não é quando } \\
\text { a velocidade de formação dos produtos é igual à dos } \\
\text { reagentes? }\end{array}$ & PCE & A5 \\
\hline 155 & Res-C & As mudanças ocorrem muito lentamente. & PCE & A4 \\
\hline 156 & Cit-C & Ou seja, não tem coisa parada. & PCE & A5 \\
\hline 157 & C-Res-C & Elas não param, elas ocorrem muito lentamente. & PCE & A4 \\
\hline
\end{tabular}

Na Figura 15 apresentamos a frequência expressa em porcentagem em que cada processamento cognitivo foi utilizado nos grupos cooperativos jigsaw na primeira e da terceira atividade para os Grupos 1 e 2 das Turmas A e C.

Figura 15 - Porcentagem de uso dos processamentos cognitivos durante a resolução da primeira e terceira atividades nos Grupos 1 e 2 da Turma A (a) e da Turma C (b), com AT1= primeira atividade e AT3= terceira atividade.

(a)

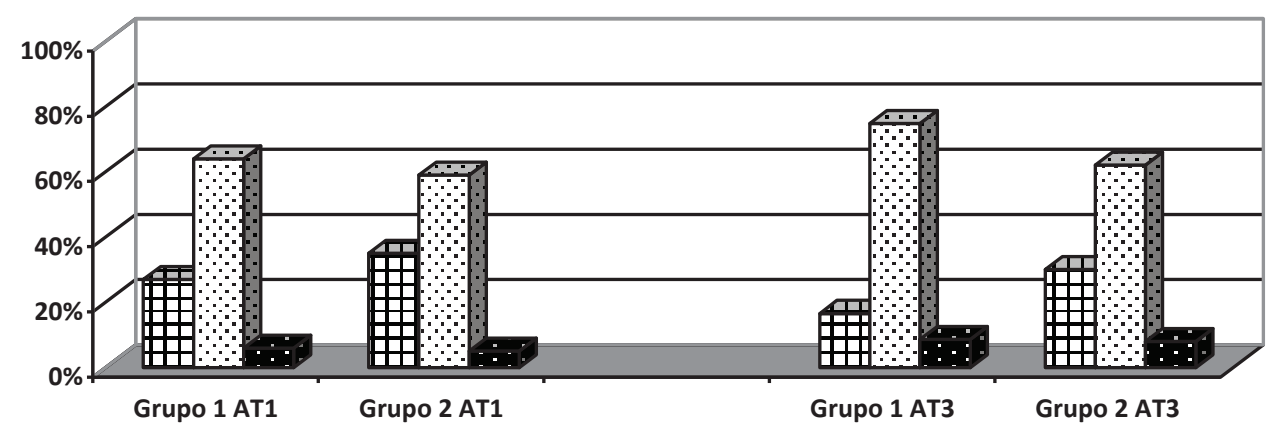

(b)

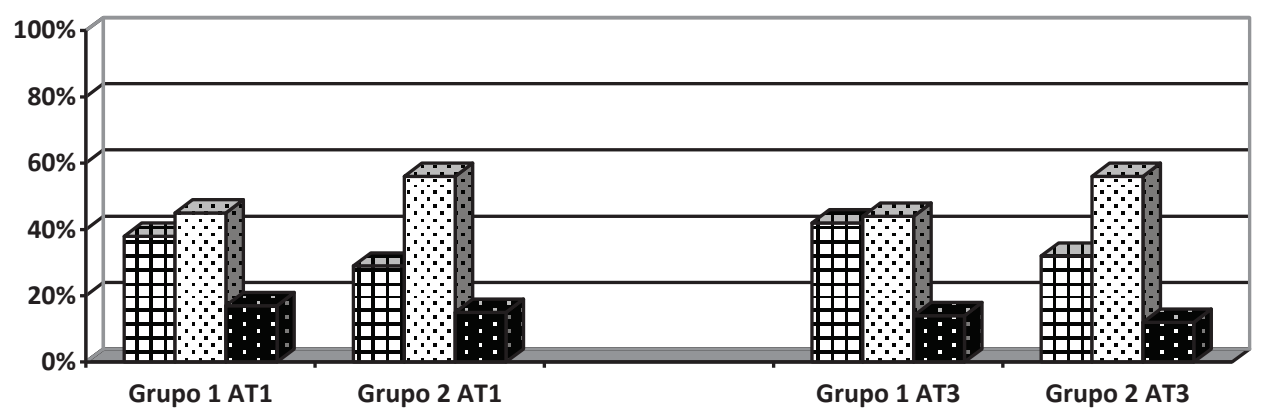

A análise da Figura 15 indica a seguinte tendência para a ocorrência dos processamentos cognitivos nos grupos: o uso do processamento cognitivo rotineiro foi superior em todos os grupos nas duas atividades das duas turmas, sendo que o menor valor apresentado foi de 44\%, na terceira atividade do Grupo 1 da Turma C, e o valor máximo de 75\%, na terceira atividade do Grupo 1 da Turma A; o 
processamento cognitivo off-task foi o segundo mais recorrente nas duas turmas, sendo que o menor valor, de $17 \%$, foi apresentado na terceira atividade do Grupo 1 da Turma A, e o valor máximo, de $42 \%$, foi apresentado na terceira atividade do Grupo 1 da Turma C; o processamento cognitivo exploratório foi o menos recorrente, sendo que o valor mínimo, de 5\%, foi apresentado na primeira atividade do Grupo 2 da Turma A e o valor máximo, de 17\%, foi apresentado na primeira atividade do Grupo 1 da Turma C.

Apesar dos valores encontrados mostrarem que o uso dos processamentos cognitivos seguiu uma tendência, ao analisá-los de forma mais minuciosa, no que diz respeito ao processamento cognitivo rotineiro, observamos que os dois grupos da Turma A fizeram uso superior aos grupos da Turma $\mathrm{C}$ em todas as atividades. Verificamos o uso mínimo de 59\% para a Turma A no Grupo 2 na primeira atividade e o valor máximo de $56 \%$ para a Turma C no Grupo 2 nas duas atividades. Esses valores denotam que o trabalho realizado na Turma $A$ apresentou um caráter mais rotineiro do que o encontrado na Turma $C$, o que reforça as nossas considerações sobre os valores encontrados para a Turma A, que fez uso superior das funções de fala do primeiro bloco, indicativas de que as atividades dessa turma apresentaram característica mais objetivas do que as realizadas na Turma $\mathrm{C}$.

De forma semelhante, os valores encontrados para os processamentos cognitivo exploratórios revelam que os dois grupos da Turma C fizeram uso superior aos grupos da Turma $A$ em todas as atividades, sendo o uso mínimo de $12 \%$ para Turma C no Grupo 2 na segunda atividade e o valor máximo de $9 \%$ para a Turma A no Grupo 1 na terceira atividade. O que mostra que as atividades da Turma C apresentaram um caráter mais exploratório do que o da Turma $A$, justificando o uso superior das funções de fala do terceiro bloco pelos grupos da Turma $C$, isso porque as referidas funções apresentam um caráter mais crítico e reflexivo, o que leva a atividade a ser usualmente mais exploratória.

Por fim, ao analisarmos comparativamente a frequência do processamento cognitivo off-task, verificamos valores variáveis para as duas turmas, com uma pequena superioridade para os grupos da Turma $C$, que apresentou valores entre $29 \%$ e $43 \%$ para os seus grupos, enquanto os grupos da Turma A apresentaram valores entre $17 \%$ e $35 \%$. Considerando os valores encontrados, é plausível afirmar que as atividades, em ambas as turmas, apresentaram um caráter de descontração 
e afetividade. Cabe ressaltar que esses valores também sugerem que, apesar das atividades da Turma $\mathrm{C}$ apresentarem um caráter mais exploratório, isso não trouxe prejuízo na afetividade e na descontração dentro das atividades.

A comparação dos valores referentes aos processamentos cognitivos para as duas turmas indica que, para o caso do processamento cognitivo rotineiro, ocorreu um crescimento nos dois grupos (Grupo 1 e Grupo 2) da Turma A da primeira para a terceira atividade. O mesmo não aconteceu nos grupos da Turma C, em relação aos quais os valores se mantiveram praticamente constantes nas duas atividades. Esses valores sugerem que, diferentemente da Turma $\mathrm{C}$, a terceira atividade realizada na Turma A exigiu dos alunos maior frequência de respostas diretas e objetivas para a sua finalização. No entanto, essa mudança não tornou as atividades significativamente mais exploratórias, mas levou a um decréscimo dos valores encontrados para os processamentos cognitivos off-task, o que mostra que a atividade apresentou um caráter menos descontraído e mais objetivo, conforme ilustram os fragmentos 29 e 30, no Quadro 18.

Quadro 18 - Trechos do mapa analítico das interações ocorridas na terceira atividade do Grupo 1 (Fragmento 29) e do Grupo 2 (Fragmento 30) da Turma A.

\begin{tabular}{|c|c|l|c|c|}
\hline $\mathbf{N}^{\circ}$ & $\begin{array}{c}\text { Função } \\
\text { de fala }\end{array}$ & \multicolumn{1}{|c|}{ Fragmento 29 } & $\begin{array}{c}\text { Processo } \\
\text { Cognitivo }\end{array}$ & Agente \\
\hline 84 & Ava & $\begin{array}{l}\text { Eu acho que a gente vai ter que escrever muito de } \\
\text { qualquer jeito. }\end{array}$ & PCR & A5 \\
\hline 85 & Int & A gente vai fazer cada um, um resumão? & PCR & A4 \\
\hline 86 & Res & Acho que é. & PCR & A5 \\
\hline 87 & Int & É a etapa dois? & PCR & A1 \\
\hline 88 & Inf & Então, o que se assemelham também, eu acho que... & PCR & A4 \\
\hline 89 & Org-A & $\begin{array}{l}\text { A gente vai fazer individual e depois a gente pega a } \\
\text { ideia e melhora. }\end{array}$ & PCR & A2 \\
\hline $\mathbf{N}^{\circ}$ & $\begin{array}{c}\text { Função } \\
\text { de fala }\end{array}$ & & $\begin{array}{l}\text { Processo } \\
\text { Cognitivo }\end{array}$ & Agente \\
\hline 37 & Int & Vai fazer uma tabela nova? & PCR & A5 \\
\hline 38 & Res-C & $\begin{array}{l}\text { Acho que daria até para completar essa, deixar } \\
\text { esses itens e fazer mais itens embaixo. }\end{array}$ & PCE & A1 \\
\hline 39 & Org-A & Eu acho que dá para usar essa também. & PCR & A4 \\
\hline 40 & Org-A & Continuar este modelo. & PCR & A3 \\
\hline 41 & Org-A & E fazer mais itens embaixo. & PCR & A1 \\
\hline 42 & Jul & E completar. & PCR & A4 \\
\hline
\end{tabular}

A observação dos fragmentos 29 e 30 sugere como a atividade proposta e o conteúdo da disciplina direcionam a forma como os alunos interagem e desenvolvem seus processamentos cognitivos. No fragmento 29 os alunos realizam ações 
rotineiras: interrogar, responder, informar e organizar, com o objetivo de ampliar a resposta dada pelo grupo na primeira atividade. Observamos fato semelhante no fragmento 30 , no qual os alunos partem de uma ação rotineira de interrogação, que recebe uma resposta crítica e exploratória, a qual denota a vontade do aluno de avançar no estudo da temática. Porém, as ações que se seguem são complementares e objetivas, revelando seu caráter mais uma vez rotineiro, com o objetivo claro de concluir a atividade de forma completa e objetiva.

Os valores de processamento cognitivo rotineiro se mantiveram constantes nos grupos da Turma $C$ nas duas atividades, conforme mencionado anteriormente. No entanto, é possível observar, a partir dos fragmentos 31 e 32, ilustrados no Quadro 19, que ambas exigem fundamentação teórica considerável sobre o assunto em estudo, mesmo para a efetuação desse tipo de processamento cognitivo. De fato, no fragmento 31, por exemplo, para que o aluno A1 complementasse a resposta direta do aluno A2 se fazia necessário o seu pleno entendimento sobre o conteúdo em discussão.

Quadro 19 - Trechos do mapa analítico das interações ocorridas na primeira (Fragmento 31) e na terceira (Fragmento 32) atividade do Grupo 2 da Turma C, exemplificando o uso do processamento cognitivo rotineiro nessa turma.

\begin{tabular}{|c|c|l|c|c|}
\hline $\mathbf{N}^{\circ}$ & $\begin{array}{c}\text { Função } \\
\text { de fala }\end{array}$ & \multicolumn{1}{|c|}{ Fragmento 31 } & $\begin{array}{c}\text { Processo } \\
\text { Cognitivo }\end{array}$ & Agente \\
\hline 307 & Int & O que você colocou, então? & PCR & A1 \\
\hline 308 & Res & Coloquei que podemos utilizar o titulador. & PCR & A2 \\
\hline 309 & LVARes & Podemos utilizar um destilado para determinar. & PCR & A1 \\
\hline 310 & C-Res-C & Aqui, com molaridade desconhecida. & PCE & A1 \\
\hline 311 & Org-I & $\begin{array}{l}\text { Coloca assim: molaridade desconhecida, porém com } \\
\text { volume conhecido na presença de um indicador. }\end{array}$ & PCE & A1 \\
\hline $\mathbf{N}^{\circ}$ & $\begin{array}{c}\text { Função } \\
\text { de fala }\end{array}$ & \multicolumn{1}{|c|}{ Fragmento 32 } & $\begin{array}{l}\text { Processo } \\
\text { Cognitivo }\end{array}$ & Agente \\
\hline 150 & Res-C & $\begin{array}{l}\text { Ponto de equivalência é quando a reação atinge, não } \\
\text { é o pH7. }\end{array}$ & PCR & A1 \\
\hline 151 & C-Res-C & Neutraliza. & PCR & A2 \\
\hline 152 & C-Res-C & Neutralização do pH. & PCR & A1 \\
\hline 153 & Jul & É. & PCR & A3 \\
\hline 154 & Cit-C & $\begin{array}{l}\text { Sim está certo. Só que indicador é o que mostra o } \\
\text { ponto de viragem. }\end{array}$ & PCE & A1 \\
\hline 155 & Int & E como eles se relacionam? & PCR & A1 \\
\hline
\end{tabular}

Tendência divergente entre as duas turmas foi também observada com relação ao processamento cognitivo off-task. Conforme ilustra a Figura 15, da 
primeira para a terceira atividade, os valores relacionados a esse processamento diminuíram para a Turma A, sugerindo maior foco na resolução da atividade por parte dos alunos. Por outro lado, os valores aumentaram ligeiramente da primeira para a terceira atividade para a Turma C, o que sugere uma maior descontração dos alunos dessa turma na última atividade.

Creditamos essa diferença, pelo menos parcialmente, à presença constante do professor durante a realização nas atividades realizadas na Turma $A$, fato que não aconteceu na Turma $\mathrm{C}$, o que pode ter contribuído para uma maior descontração dos alunos nas atividades dessa última. Nessa perspectiva, as condições impostas em sala de aula, aparentemente, influenciaram as interações estabelecidas, gerando processamentos cognitivos diversos.

Com relação ao processamento cognitivo exploratório, conforme ilustra a Figura 15, os valores seguiram tendências bem definidas para as duas turmas. Foi observado um pequeno aumento no uso desse processamento nos grupos da Turma A (valor aproximado de $2 \%$ ) da primeira para a terceira atividade, enquanto para os grupos da Turma $\mathrm{C}$ encontramos uma pequena redução no uso desse processamento (diminuição de aproximadamente 3\%).

O Quadro 20 apresenta trechos dos mapas analíticos desenvolvidos na primeira e na terceira atividades da Turma C para o Grupo 1, com destaque para o uso do processamento cognitivo exploratório.

Quadro 20 - Trechos do mapa analítico das interações ocorridas na primeira (Fragmento 33) e na terceira atividade (Fragmento 34) do Grupo 1 da Turma C, exemplificando o uso do processamento cognitivo exploratório nessa turma.

\begin{tabular}{|c|c|l|c|c|}
\hline $\mathbf{N}^{\circ}$ & $\begin{array}{c}\text { Função } \\
\text { de fala }\end{array}$ & \multicolumn{1}{|c|}{ Fragmento 33 } & $\begin{array}{c}\text { Processo } \\
\text { Cognitivo }\end{array}$ & Agente \\
\hline 154 & Int & $\begin{array}{l}\text { Por que quando você tem um equilíbrio, não é quando a } \\
\text { velocidade de formação dos produtos é igual à dos } \\
\text { reagentes? }\end{array}$ & PCE & A5 \\
\hline 155 & Res-C & As mudanças ocorrem muito lentamente. & PCE & A4 \\
\hline 156 & Cit-C & Ou seja, não tem coisa parada. & PCE & A5 \\
\hline 157 & C-Res-C & Elas não param, elas ocorrem muito lentamente. & PCE & A4
\end{tabular}


Quadro 20 - Trechos do mapa analítico das interações ocorridas na primeira (Fragmento 33) e na terceira atividade (Fragmento 34) do Grupo 1 da Turma C, exemplificando o uso do processamento cognitivo exploratório nessa turma.

(conclusão)

\begin{tabular}{|l|c|l|c|c|}
\hline $\mathbf{N}^{\circ}$ & $\begin{array}{l}\text { Função } \\
\text { de fala }\end{array}$ & \multicolumn{1}{|c|}{ Fragmento 34 } & $\begin{array}{c}\text { Processo } \\
\text { Cognitivo }\end{array}$ & Agente \\
\hline 29 & Res-C & $\begin{array}{l}\text { No caso da reação, tem que ver que tipo de reação é, } \\
\text { porque ela acontece nos dois sentidos, ou seja, ela tem } \\
\text { reversibilidade. }\end{array}$ & PCE & A1 \\
\hline 30 & Afe & Ela não te dá atenção. & PCR & A5 \\
\hline 31 & C-Res-C & Ela pode ser reversível em qualquer momento. & PCE & A3 \\
\hline 32 & Cit-C & $\begin{array}{l}\text { Não. Reversibilidade nesse caso não é em relação ao } \\
\text { processo reversível. Reversibilidade, nesse caso, é só } \\
\text { em relação à reação direta ou inversa. }\end{array}$ & PCE & A1 \\
\hline 33 & C-Res-C & $\begin{array}{l}\text { Por exemplo, o equilíbrio tem a composição do sistema } \\
\text { e a composição do sistema tem uma determinada } \\
\text { variação de energia livre. E ela vai tendendo até a } \\
\text { variação de energia ser igual a zero. }\end{array}$ & PCE & A1 \\
\hline
\end{tabular}

No Quadro 20 observamos como os alunos da Turma C apresentam um processamento cognitivo exploratório com um sólido embasamento teórico e todas as suas participações são voltadas para ampliar a temática que está sendo estudada. No fragmento 33, dois alunos iniciam uma interação com uma interrogação que não é feita pelo professor e sim pelo próprio aluno (A5) que tenta, por meio dela, ampliar a discussão, que culmina com resposta crítica, citação crítica e complemento de resposta crítica. De forma similar, o fragmento 32 reafirma nosso apontamento e demonstra como os alunos usam o processamento cognitivo exploratório direcionado para ampliar a resposta baseada em conhecimento teórico.

O Quadro 21 apresenta trechos dos mapas analíticos desenvolvidos na primeira atividade do Grupo 1 e na terceira atividade do Grupo 2, ambos da Turma A, também com destaque para o uso do processamento cognitivo exploratório.

Quadro 21 - Trechos do mapa analítico das interações ocorridas na primeira atividade do Grupo 1 (Fragmento 35) e na terceira atividade do Grupo 2 (Fragmento 36) da Turma A, exemplificando o uso do processamento cognitivo exploratório nessa turma.

\begin{tabular}{|c|c|l|c|c|}
\hline $\mathbf{N}^{\circ}$ & $\begin{array}{l}\text { Função } \\
\text { de fala }\end{array}$ & \multicolumn{1}{|c|}{ Fragmento 35 } & $\begin{array}{l}\text { Processo } \\
\text { Cognitivo }\end{array}$ & Agente \\
\hline 440 & Org-I & $\begin{array}{l}\text { Eu acho que o de vocês que a gente tem } \\
\text { familiaridade, não só porque ele fala sobre a água, } \\
\text { mas porque ele fala de água em geral. Ele cita } \\
\text { tratamento, poluição. Fala sobre a falta de água no } \\
\text { futuro. Isso aí é noticiário, sempre está sendo } \\
\text { publicado. }\end{array}$ & A2 \\
\hline 441 & Int & $\begin{array}{l}\text { Essa parte de educação não é como se fosse artigo } \\
\text { de professor? }\end{array}$ & PCE & A1 \\
\hline 442 & Res-C & $\begin{array}{l}\text { Não só para o professor como para o aluno. Por isso } \\
\text { que a linguagem é mais simples e mais facilitada, } \\
\text { acho que o seu também dá para entender. }\end{array}$ & PCE & A2 \\
\hline
\end{tabular}


Quadro 21 - Trechos do mapa analítico das interações ocorridas na primeira atividade do Grupo 1 (Fragmento 35) e na terceira atividade do Grupo 2 (Fragmento 36) da Turma A, exemplificando o uso do processamento cognitivo exploratório nessa turma.

\begin{tabular}{|c|c|l|c|c|}
\hline $\mathbf{N}^{\circ}$ & $\begin{array}{c}\text { Função } \\
\text { de fala }\end{array}$ & \multicolumn{1}{|c|}{ Fragmento 36 } & $\begin{array}{l}\text { Processo } \\
\text { Cognitivo }\end{array}$ & Agente \\
\hline 21 & Cit-C & $\begin{array}{l}\text { Mas de boa, o meu não teve mudança radical que ela } \\
\text { falou que ia ter. }\end{array}$ & PCE & A1 \\
\hline 22 & Cit-C & Eu acho que a mudança vai ser nesse quadro. & PCE & A4 \\
\hline 23 & Org-I & $\begin{array}{l}\text { O que a gente vai fazer nesse quadro, não vai ser } \\
\text { muito isso aqui, vai ser outra coisa, eu entendi nesse } \\
\text { sentido: a gente não vai colocar só a linguagem e o } \\
\text { público alvo, tem mais coisas a acrescentar. }\end{array}$ & PCE & A4 \\
\hline 24 & Org-I & $\begin{array}{l}\text { Eu acho mais fácil não fazer quadro, escreve tese e } \\
\text { coloca o que é. }\end{array}$ & PCE & A2 \\
\hline
\end{tabular}

No fragmento 35 os alunos usam impressões pessoais para organizar as ideias e para responder de forma crítica e, mesmo trabalhando a temática proposta, não se percebe um embasamento aprofundado sobre ela. De forma similar, no fragmento 36 , os alunos novamente desenvolvem uma passagem exploratória. Entretanto, o teor crítico na condução da atividade está relacionado com a formulação e condução da atividade e não com o conteúdo de forma específica.

\subsubsection{Análise das interações discursivas na perspectiva da terceira dimensão: processamento social}

A análise das interações discursivas permitiu a identificação dos quatro tipos de processamentos sociais: colaborativo, tutorial, individualista e competitivo. $\mathrm{O}$ primeiro é caracterizado pela igual participação dos membros do grupo na realização das tarefas. O segundo é caracterizado pelo auxílio prestado por um estudante ou professor a outro membro na realização da tarefa. O terceiro é caracterizado pelo trabalho confuso e sem compartilhamento das dúvidas e conclusões com os demais membros do grupo, ou pelo domínio de um membro sobre a realização da tarefa. $O$ quarto é caracterizado por conflitos sociais e acadêmicos não solucionados ou que interfiram na execução da tarefa.

Com base nas informações contidas nos mapas analíticos, identificamos as interações dominantes ocorridas no decorrer da resolução da primeira e terceira atividades dos dois grupos da Turma A e da Turma C. A Figura 16 ilustra os tipos de interações sociais considerados, assim como a porcentagem com que cada um foi utilizado. 
Figura 16 - Porcentagem de uso dos processamentos cognitivos sociais durante a resolução das três atividades dos Grupos 3 e 4 da Turma C (a) e das três atividades do Grupos 1 da Turma B (b), AT1 = primeira atividade e AT3= terceira atividade.

(a)

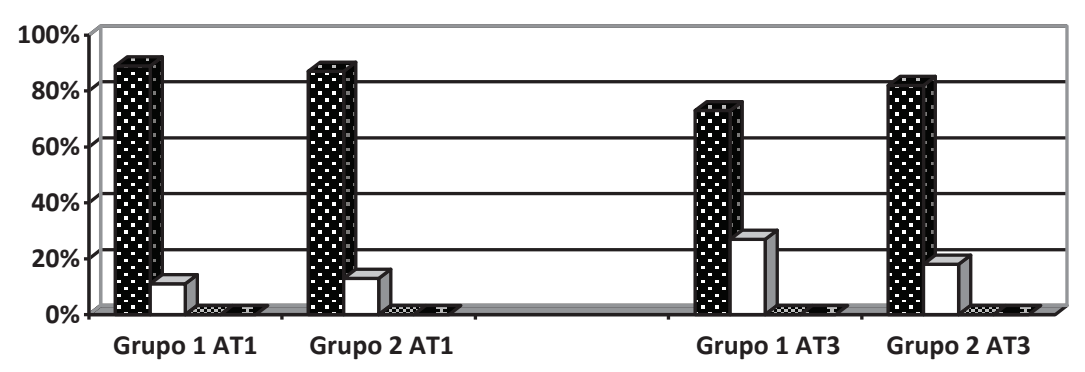

(b)

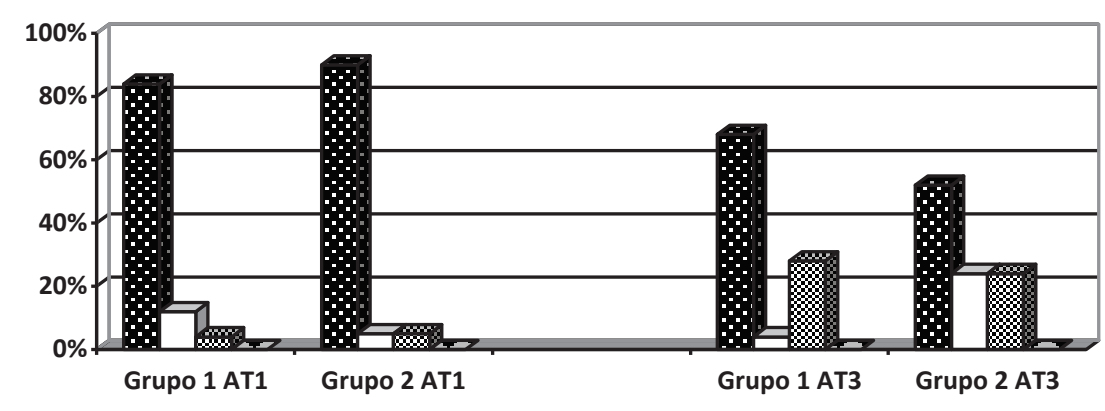

Tanto na Turma A quanto na Turma $\mathrm{C}$ o processamento social predominante em todas as atividades foi do tipo colaborativo, com valores superiores a $70 \%$ nos quatro encontros da Turma A. Para a Turma $C$ os valores encontrados para esse tipo de processamento também foram predominantes. Assim, os valores revelam que as atividades das duas turmas tiveram a colaboração como característica social principal.

Entretanto, ocorreu um decréscimo do caráter colaborativo da primeira para a terceira atividade nos dois grupos das duas turmas, com valores, de $84 \%$ para $68 \%$ no Grupo 1 e de $90 \%$ para $52 \%$, no Grupo 2, ambos da Turma C. Os valores citados estão de acordo com os encontrados nas outras dimensões de análise: a redução encontrada para o processamento do tipo colaborativo na Turma $C$ tem relação direta com a descontração das atividades realizadas, conforme mencionado anteriormente.

O segundo processamento social mais recorrente na Turma $A$ foi do tipo tutorial, com valores indo de $11 \%$ no Grupo 1 , na primeira atividade, a $27 \%$ na terceira atividade. Como esperado, esses valores não se repetiram com tanta frequência nas atividades da Turma $\mathrm{C}$, uma vez que os alunos não contavam com a 
presença do professor em sala, que é o fator que costuma gerar esse tipo de processamento.

Os valores encontrados para o processamento do tipo individualista se destacaram na Turma C, especialmente na terceira atividade dos dois grupos, e não foram identificados na Turma A, o que pode estar relacionado com o fato de a Turma C não contar com o professor durante a atividade. Denotamos, ainda, que as atividades realizadas pela Turma $\mathrm{C}$, apesar de ligadas à disciplina, ocorreram em momentos fora do horário de aula da turma. Também pode-se chamar a atenção para o fato de os processamentos sociais individualistas ocorrerem de formas distintas e com objetivos diferentes, como será demostrado a seguir.

O Quadro 22 apresenta trechos dos mapas analíticos desenvolvidos na primeira e na terceira atividade da Turma C para o Grupo 1. Nele destacamos momentos que geraram processamentos do tipo individualista.

Quadro 22 - Trechos do mapa analítico das interações ocorridas na primeira (Fragmento 37) e na terceira (Fragmento 38) atividade do Grupo 1 da Turma C, exemplificando momentos que geraram processamentos sociais do tipo individualista.

\begin{tabular}{|c|c|c|c|c|}
\hline $\mathbf{N}^{\circ}$ & $\begin{array}{l}\text { Função } \\
\text { de fala }\end{array}$ & Fragmento 37 & $\begin{array}{l}\text { Processo } \\
\text { Cognitivo }\end{array}$ & Agente \\
\hline 574 & & No meio da boca dele. & PCO & A1 \\
\hline 575 & & Mr. M, o menino. & PCO & A4 \\
\hline 576 & & $\begin{array}{l}\text { Aí só depois ele foi falar que, na hora em que ele caiu, } \\
\text { ele abriu a boca. Ahhhh. }\end{array}$ & PCO & A1 \\
\hline 577 & & Eu achei meio estranho. & PCO & A1 \\
\hline 578 & Org-A & Mas, enfim, vamos voltar. Questão quatro. & PCR & A1 \\
\hline $\mathbf{N}^{\circ}$ & $\begin{array}{l}\text { Função } \\
\text { de fala }\end{array}$ & Fragmento 38 & $\begin{array}{l}\text { Processo } \\
\text { Cognitivo }\end{array}$ & Agente \\
\hline 418 & & $\begin{array}{l}\text { Será que ele vai corrigir logo essa prova? Eu quero } \\
\text { ver a minha nota. }\end{array}$ & PCO & A3 \\
\hline 419 & & Não é? & PCO & A5 \\
\hline 420 & & Que demora, povo enrolado. & PCO & A3 \\
\hline 421 & & Eu não sei se eu vou ter que tirar um dez ou um oito. & PCO & A5 \\
\hline 422 & & Você foi mal na segunda? & PCO & A3 \\
\hline 423 & & Eu não sei. & PCO & A5 \\
\hline
\end{tabular}

No fragmento 37 observa-se um momento dominado por processamentos cognitivos off-task. Nele um aluno domina as interações e, ao desviar o foco da atividade para contar uma anedota, acaba não permitindo que os demais realizem a atividade de forma objetiva. Nota-se que a atividade só volta a ter característica colaborativa quando o aluno A1 resolve chamar a atenção dos outros para voltarem a resolver a tarefa proposta. Momentos como o citado no fragmento 37 ocorreram 
nas duas atividades do Grupo 1 e nas duas atividades do Grupo 2 da Turma C, porém não foram dominantes.

Outra forma observada do processamento social individualista está representada no fragmento 38. Nele os alunos, no começo ou no final da atividade, realizam conversas descontraídas que não têm relação com a mesma, mas não chegam a atrapalhar o seu desenvolvimento. Esses momentos ocorrem com maior frequência no começo da atividade, quando os alunos ainda estão se organizando, e no final, quando esta praticamente já está finalizada. Relacionamos o aumento na frequência dessa interação social com a ausência do professor no local, o que imprime caráter mais lúdico e descontraído à atividade, realizada fora da sala de aula e com o aspecto de finalização observado em alguns desses momentos.

Cabe ressaltar que a análise do processamento social permite verificar o comportamento dominante e individualista, como o representado no fragmento 37 , que pela perspectiva das duas dimensões anteriores permanecia camuflado.

Com relação à interação social do tipo processamento competitivo verifica-se que não foi caracterizada em nenhum dos quatro grupos das turmas, o que demonstra a efetivação dos ideais e das bases que fomentam a aprendizagem cooperativa, que surge como uma alternativa para reduzir a aprendizagem baseada na competição, fortalecendo o comportamento colaborativo entre os alunos, como ficou caracterizado nas análises anteriores.

A discussão dos dados apresentados até o momento fornece subsídios para que possamos fazer considerações sobre a nossa primeira questão de pesquisa: de que forma a natureza específica da disciplina pode influenciar na dinâmica das interações discursivas em um grupo cooperativo jigsaw?

Observamos que o fato de os alunos da Turma A terem lidado nos grupos cooperativos jigsaw com atividades que versavam sobre tipos de documentos científicos (Figura 11) e suas características peculiares permitiu que lançassem mão de conhecimentos dos quais já eram detentores ou que estavam disponíveis no livro didático da disciplina (OLIVEIRA; QUEIROZ, 2007) para o alcance dos seus objetivos. Dessa maneira, as interações discursivas foram fortemente pautadas no uso das funções de fala do primeiro bloco, acionadas pelos alunos na intenção de alcançar respostas diretas e objetivas, que se mostraram suficientes para a resolução da atividade proposta pelo professor. Nessa perspectiva, uma única 
interrogação recebeu, com frequência, mais de uma resposta e complemento de resposta.

O processamento cognitivo predominante observado foi o rotineiro, que chegou a sobrepujar o processamento cognitivo exploratório em pelo menos sete vezes para todas as atividades. Constatação esta que é perfeitamente coerente com as funções de fala mais fortemente utilizadas. De fato, o uso das funções interrogação, resposta, complemento de resposta, informação e leitura em voz alta tendem a desencadear processamentos cognitivos do tipo em questão. 0 processamento cognitivo off-task tornou-se menos recorrente nas atividades finais, frente às iniciais, ocorrendo tendência contrária com relação ao processamento cognitivo exploratório. Acreditamos que estas duas tendências estão interligadas, até certo ponto, pois a terceira atividade foi nitidamente mais complexa que a primeira e teve caráter de continuidade bem marcante com relação a ela. Ou seja, os alunos retomaram na terceira atividade uma tabela que haviam construído na primeira e ampliaram o seu leque de conteúdos a partir de informações oferecidas pelos alunos, após a passagem pelo grupo de especialistas. Dessa maneira, o processamento cognitivo exploratório foi ampliado e o off-task reduzido.

Apenas o processamento social colaborativo e o tutorial foram observados na Turma $A$, o que se constitui em resultado bastante animador, uma vez que o caráter individualista, assim como o competitivo não permearam as atividades.

O fato dos alunos da Turma $\mathrm{C}$ terem lidado nos grupos cooperativos jigsaw com atividades que versavam sobre Equilíbrio Químico, conteúdo de grande complexidade no contexto do ensino de Química (CABORIN; SERRANO, 2007), exigiu que se empenhassem em discussões mais críticas para o alcance dos seus objetivos. Dessa maneira, as interações discursivas foram fortemente pautadas no uso das funções de fala do terceiro bloco, acionadas pelos alunos de forma vigorosa na elaboração de citações, respostas e complementos de resposta crítica, assim como na sumarização de ideias, a partir da função organização de ideias. As funções de fala do segundo bloco, julgamento e organização de ação, também estiveram muito mais presentes nas interações discursivas dos alunos da Turma $C$, frente aos da Turma A. Nas ocasiões em que estas foram identificadas na Turma C, mantiveram caráter de interação de forma sistemática e organizada.

Assim como para a Turma A, o processamento cognitivo predominante observado foi o rotineiro. No entanto, o processamento cognitivo exploratório foi 
muito mais significativo na Turma $C$ do que na Turma $A$, sendo sobrepujado no máximo em 4,5 vezes. Constatação esta que é perfeitamente coerente com as funções de fala mais fortemente utilizadas. De fato, o uso das funções citação crítica, organização de ideia, resposta crítica e complemento de resposta crítica tendem a desencadear processamentos cognitivos do tipo em questão. $O$ processamento cognitivo off-task tornou-se mais recorrente nas atividades finais, frente às iniciais, ocorrendo tendência contrária com relação ao processamento cognitivo exploratório. Acreditamos que estas duas tendências, diferentemente do observado para a Turma A, não estão tão diretamente interligadas, pois a terceira atividade, embora nitidamente mais complexa que a primeira, não teve caráter de continuidade marcante com relação a ela. Assim, não ocorreu uma retomada direta, na terceira atividade, do que havia sido feito na primeira, o que não implicou em um processamento cognitivo exploratório maior.

Apenas o processamento social competitivo não foi observado na Turma C e o processamento social colaborativo foi também o predominante, assim como na Turma A. Porém, o processamento cognitivo individualista esteve presente em todos os grupos da Turma C, embora estivesse completamente ausente na Turma A. A ausência do professor durante as atividades da Turma C pode ter gerado este resultado, assim como a limitada presença de processamento social do tipo tutorial.

A partir da investigação da dinâmica das interações discursivas estabelecidas entre os alunos nos grupos cooperativos jigsaw, ainda é possível destacar algumas potencialidades das atividades desenvolvidas em tais contextos.

O trabalho de Doymus (2007), assim como o aqui relatado, trata do ensino de conteúdo de Química que se configura como de difícil entendimento por parte dos alunos (Ligação Química), a partir da aplicação da estratégia jigsaw. Os resultados indicam que as atividades realizadas nos grupos cooperativos contribuíram para o melhor entendimento do assunto e para a superação de concepções alternativas a seu respeito. Embora o nosso objetivo não tenha sido o de investigar o desempenho acadêmico dos alunos a partir da estratégia adotada, acreditamos que elevada recorrência das funções de fala do terceiro bloco nos grupos que se dedicaram ao estudo do conteúdo Equilíbrio Químico e o teor considerável de processamentos cognitivos do tipo exploratório corroboram os estudos do referido autor. Nessa perspectiva, destacamos fortemente a potencialidade da estratégia jigsaw na 
promoção de aprendizagem de conteúdos de Química e julgamos que o fato da mesma permitir que os alunos compartilhem, inicialmente, seus conhecimentos prévios sobre o assunto e, em seguida, sejam encarregados de trazer para os colegas novas informações sobre o tema contribui para isso (BERGER; HÄNZE, 2009).

Os nossos resultados também estão em sintonia com os reportados por Anderson, Mitchell e Osgood (2005) que indicam a potencialidade de métodos cooperativos no aprimoramento do rendimento de alunos, especialmente os de desempenho mediano, provavelmente devido ao papel ativo que passam a desempenhar durante a atividade. De fato, vários fragmentos exibidos anteriormente (por exemplo, o fragmento 18 do Quadro 14) evidenciam a participação de todos os membros de um mesmo grupo na busca de resolução para as tarefas propostas, tornando inquestionável a assertiva sobre o papel central que os alunos assumiram nas Turmas A e C.

Durán e Sánchez-Guzmán (2010) relatam o desenvolvimento de habilidades interpessoais por parte dos alunos a partir da realização de atividades em grupos cooperativos jigsaw, enquanto Berland e Lee (2012), ao se referirem ao mesmo tipo de grupo, tratam do desenvolvimento das habilidades de argumentação. Os valores elevados encontrados para o processamento social do tipo colaborativo em todos os grupos nas Turmas A e C corroboram as observações dos autores com relação à potencialidade da estratégia no desenvolvimento das habilidades interpessoal. De forma similar, a recorrência de funções de fala do tipo julgamento e avaliação, especialmente na Turma $\mathrm{C}$, sugere que muitas delas são desencadeadas em contextos argumentativos.

Portanto, a análise global das três dimensões aponta para a oportunidade que os alunos de ambas as disciplinas tiveram de aperfeiçoar suas habilidades acadêmicas com relação aos diversos conteúdos ministrados. Também podemos inferir que a atividade cooperativa se mostrou capaz de promover um ambiente propício para o desenvolvimento de respostas bem elaboradas mesmo em ambientes diversificados e frente a conteúdos com caraterísticas diferentes, como asseverado pelos autores Garcia e Tunón (2004) e Valverde, Jiménez e Viza (2005), os quais sugerem a adoção da aprendizagem cooperativa como promotora de um ambiente em que os alunos produzem melhores respostas aos problemas proposto. A aplicabilidade da estratégia jigsaw às duas disciplinas, que tratam de conteúdos 
tão diversos, foi também constatada, o que respalda os resultados encontrados por Tanner, Chatman e Allen (2003) e Valverde e Viza (2006).

\subsection{Influência da natureza das disciplinas na dinâmica das interações discursivas em grupo colaborativo PLTL}

As interações discursivas estabelecidas nos grupos colaborativos PLTL nas Turmas B e C foram analisadas com base em três dimensões: função de fala, processamento cognitivo e processamento social. Cada uma dessas funções será analisada a seguir separadamente.

\subsubsection{Análise das interações discursivas na perspectiva da primeira dimensão: função de fala}

Seguindo o modelo do tópico anterior, com o intuito de facilitar a análise das interações discursivas na perspectiva das funções de fala, estas foram distribuídas em três blocos.

No Quadro 23 apresentamos a frequência expressa em porcentagem em que cada função de fala foi utilizada nos grupos colaborativos PLTL nas Turmas B e C, para cada bloco de análise. Nele apresentamos os dados obtidos para o Grupo 1 na Turma B e para os Grupos 3 e 4 da Turma C, nas três atividades.

Para as funções de fala que compõem o primeiro bloco (interrogação, resposta, complemento de resposta, informação e leitura em voz alta), nos três grupos colaborativos, encontramos somatória próxima a 50,0\%, com o menor valor $(46,4 \%)$ encontrado na terceira atividade do Grupo 1 da Turma B e com o maior valor $(56,3 \%)$ encontrado na primeira atividade do Grupo 1 da Turma B. Observa-se que as turmas apresentaram valores muito próximos, o que permite fazer uma análise geral que represente o que aconteceu em todos os grupos. O uso significativo dessas funções indica que os alunos se mantiveram dedicados à resolução das atividades em ambas as turmas. Por meio delas, eles fazem a leitura do material de referência e do material produzido durante a atividade, oferecem informações, questionam e respondem às perguntas lançadas ao grupo. Dessa forma, o resultado indica o comprometimento dos alunos em sua resolução. 
Algumas peculiaridades, no entanto, distinguem as interações estabelecidas em cada uma das turmas.

Quadro 23 - Distribuição das funções de fala para os Grupos PLTL, nas três atividades do Grupo 1 da Turma B e nas três atividades dos Grupos 3 e 4 da Turma C.

\begin{tabular}{|c|c|c|c|c|c|c|c|c|c|c|}
\hline & \multirow{2}{*}{\multicolumn{3}{|c|}{$\begin{array}{c}\text { Turma B } \\
\underset{\text { Grupo } 1}{(\%)}\end{array}$}} & \multicolumn{6}{|c|}{ Turma C } \\
\hline & & & & & \multicolumn{3}{|c|}{$\begin{array}{c}\text { Grupo } 3 \\
\text { (\%) }\end{array}$} & \multicolumn{3}{|c|}{$\begin{array}{c}\text { Grupo } 4 \\
\text { (\%) }\end{array}$} \\
\hline & & AT1 & AT2 & AT3 & AT1 & AT2 & AT3 & AT1 & AT2 & AT3 \\
\hline \multirow{6}{*}{$\begin{array}{l}\text { ¿ } \\
\text { o } \\
0\end{array}$} & Int & 20,2 & 19,5 & 17,5 & 23,2 & 22,2 & 26,4 & 20,1 & 15,5 & 21,9 \\
\hline & Res & 17,0 & 13,9 & 9,3 & 11,9 & 11,4 & 13,1 & 10,8 & 7,4 & 10,3 \\
\hline & C-Res & 4,8 & 4,2 & 2,6 & 4,4 & 4,1 & 4,7 & 9,3 & 6,1 & 4,4 \\
\hline & Inf & 12,6 & 10,3 & 15,2 & 4,2 & 9,5 & 5,7 & 6,5 & 12,8 & 11,7 \\
\hline & LVA & 1,7 & 0,6 & 1,7 & 4,2 & 5,4 & 2,0 & 2,8 & 5,9 & 3,1 \\
\hline & Soma & 56,3 & 48,5 & 46,4 & 47,9 & 52,6 & 51,9 & 49,5 & 47,7 & 51,4 \\
\hline \multirow{6}{*}{$\begin{array}{l}\text { N } \\
\text { O } \\
\text { o }\end{array}$} & Org-A & 9,8 & 5,5 & 7,0 & 8,3 & 7,0 & 7,2 & 11,4 & 8,7 & 13,9 \\
\hline & Exp & 5,9 & 7,1 & 7,0 & 4,6 & 5,1 & 7,6 & 4,0 & 6,1 & 4,2 \\
\hline & Jul & 10,6 & 13,2 & 10,5 & 8,1 & 9,8 & 7,2 & 8,0 & 9,6 & 8,1 \\
\hline & Ava & 5,4 & 7,8 & 8,5 & 2,1 & 2,9 & 3,2 & 2,8 & 4,1 & 1,7 \\
\hline & Afe & 0,9 & 0,2 & 0,3 & 0,2 & 0,3 & 1,5 & 0,3 & 0,4 & 0,8 \\
\hline & Soma & 32,6 & 33,8 & 33,2 & 23,3 & 25,1 & 26,7 & 26,5 & 28,9 & 28,7 \\
\hline \multirow{5}{*}{$\begin{array}{l}\text { m } \\
\text { ठ } \\
\text { o }\end{array}$} & Cit-C & 7,0 & 6,5 & 11,4 & 7,3 & 5,4 & 4,2 & 2,5 & 2,6 & 2,5 \\
\hline & Org-I & 1,3 & 2,7 & 2,6 & 8,6 & 2,9 & 5,4 & 5,6 & 2,0 & 4,2 \\
\hline & Res-C & 1,3 & 2,5 & 2,9 & 5,0 & 6,7 & 3,4 & 3,7 & 1,2 & 4,4 \\
\hline & C-Res-C & 1,5 & 5,9 & 3,5 & 7,9 & 7,3 & 8,4 & 12,4 & 17,6 & 8,9 \\
\hline & Soma & 11,1 & 17,6 & 20,4 & 28,8 & 22,3 & 21,4 & 24,2 & 23,4 & 20 \\
\hline
\end{tabular}

Int = interrogação; Res= resposta; C-Res= complemento de resposta; Inf= informação; LVA= leitura em voz alta; Org-A= organização de ação; Exp= experencial; Jul= julgamento; Ava= avaliação; $A f e=$ afetiva; Cit-C= citação crítica; Org-I organização de ideia; Res-C= resposta crítica e C-Res-C= complemento de resposta crítica; $A T 1=$ primeira atividade, $A T 2=$ segunda atividade e $A T 3=$ terceira atividade.

Na Turma B os alunos fizeram uso ligeiramente superior da função de fala do tipo informação, com valores entre 10,3\% e 15,2\%. Já para os alunos da Turma C, para a mesma função, encontramos valores entre 4,2\% e 9,5\% para o Grupo 3 e valores entre 6,5\% e 12,8\% para o Grupo 4. Essa diferença sugere que os alunos da Turma B usaram a função de informação para direcionar a realização da atividade, o que, provavelmente, se relaciona com a sua natureza. Conforme indicado no tópico Percurso Metodológico, constava como parte da atividade dessa turma a escolha dos exercícios mais complexos da lista disponibilizada em sala de aula pelo professor. Assim, para a realização dessa etapa os alunos usaram a função de fala 
do tipo informação com o intuito de demonstrar suas opiniões e conduzir a atividade, como pode ser observado no Quadro a seguir.

O Quadro 24 apresenta trechos do mapa analítico da primeira atividade do Grupo 1 da Turma B. Nele é apresentado o fragmento 39 que evidencia a forma como a função de fala do tipo informação é utilizada. Cabe ressaltar que, assim como foi feito anteriormente, os fragmentos das diferentes turmas serão apresentados com sombreamentos distintos: os fragmentos pertencentes à Turma $\mathrm{C}$ com sombreamento cinza e os fragmentos da Turma B sem sombreamento.

Quadro 24 - Trechos do mapa analítico das interações ocorridas na primeira atividade do Grupo 1 da Turma B (Fragmento 39).

\begin{tabular}{|c|c|l|c|}
\hline $\mathbf{N}^{\circ}$ & $\begin{array}{c}\text { Função } \\
\text { de fala }\end{array}$ & \multicolumn{1}{|c|}{ Fragmento 39 } & Agente \\
\hline 171 & Inf & O (exercício) nove também. & A1 \\
\hline 172 & Inf & O (exercício) um e o dois foram resolvidos no caderno. & A5 \\
\hline 173 & Org-I & $\begin{array}{l}\text { Como vocês podem ver, a teoria das colisões tem muita matemática. } \\
\text { Tem que diferenciar o Z e o Z de AB, e o Z de AB zero. }\end{array}$ & A5 \\
\hline 174 & Inf & Porque tem uma diferença entre um e outro. & A5 \\
\hline 175 & Ava & Essa (lista de exercício) é difícil mesmo. & A4 \\
\hline
\end{tabular}

O fragmento 39 ilustra como os alunos A1 e A5 usam informações para direcionar a escolha do exercício. Em seguida, este último usa a função de organização de ideia para embasar sua escolha e encerra a participação com outra informação. Por fim, o aluno A4 apresenta a sua avaliação sobre a lista em discussão. É nessa perspectiva que a função de fala informação direciona as interações discursivas, justificando os resultados encontrados.

Diferentemente, na Turma C, os alunos fizeram uso superior da função de fala do tipo leitura em voz alta, com valores entre 2,0\% e 5,9\% para os dois grupos. Já para o grupo da Turma $B$, em relação à mesma função, encontramos valores entre 0,6\% e 1,7\%. Essa diferença se justifica pelo fato da função de fala de leitura em voz alta direcionar a resolução da atividade nos grupos da Turma C. De fato, na disciplina Introdução à Química era imprescindível a leitura dos livros indicados pelo docente para alcance de respostas às questões teóricas propostas. Esta leitura era feita, muitas vezes, por um dos membros do grupo, no momento da resolução das questões.

O Quadro 25 apresenta trechos do mapa analítico da segunda atividade do Grupo 3 da Turma C. 
Quadro 25 - Trecho do mapa analítico das interações ocorridas na segunda atividade do Grupo 3 da Turma C (Fragmento 40).

\begin{tabular}{|c|c|l|c|}
\hline $\mathbf{N}^{\circ}$ & $\begin{array}{l}\text { Função de } \\
\text { fala }\end{array}$ & \multicolumn{1}{|c|}{ Fragmento 40} & Agente \\
\hline 209 & LVA/Res-C & $\begin{array}{l}\text { A presença de Ag provoca uma perturbação no equilíbrio de } \\
\text { solubilidade e, de acordo com o princípio de Le Chatelier, o } \\
\text { equilíbrio deve se deslocar no sentido de minimizar essa. }\end{array}$ & $\mathrm{A}$ \\
\hline 210 & Jul & Sim. & $\mathrm{A} 2$ \\
\hline 211 & Cit-C & $\begin{array}{l}\text { Portanto, podemos inferir que a solubilidade de cloreto de prata } \\
\text { dividida pela concentração de cloreto é igual. }\end{array}$ & $\mathrm{A} 1$ \\
\hline 212 & Ava & Travou. & $\mathrm{A} 3$ \\
\hline 213 & C-Res-C & $\begin{array}{l}\text { O equilíbrio deve se deslocar no sentido de minimizar tal efeito. } \\
\text { Portanto, podemos inferir que a solubilidade do cloreto de prata na } \\
\text { solução de Ag+ deve ser menos do que em água pura. }\end{array}$ & $\mathrm{A} 1$ \\
\hline 214 & Org-I & $\begin{array}{l}\text { Agora começa a fazer sentido o que falamos na outra sala, porque } \\
\text { ele misturou cloreto de prata com nitrato de prata. Os dois têm } \\
\text { prata se você joga na mesma água ou solução. }\end{array}$ & $\mathrm{A} 1$ \\
\hline
\end{tabular}

O fragmento 40 do Quadro 25 ilustra como os alunos usam a função de fala leitura em voz alta. O aluno A1 faz uma leitura da teoria exposta no livro didático e essa leitura em voz alta será usada como resposta crítica ao exercício. Em seguida, o aluno A2, fazendo uso da função de julgamento, concorda com o que foi lido, o que leva o aluno A1 a realizar uma citação crítica. Entretanto, como o aluno A1 não consegue finalizar sua ideia, ele tem sua fala avaliada em tom de brincadeira pelo aluno A3. Por fim, o trecho é finalizado com o aluno A1 complementando sua resposta de forma crítica e, em seguida, usando a função de organização de ideia para expor suas conclusões. Cabe destacar que as interações estabelecidas estão baseadas em conceitos previamente encontrados no material indicado pelo docente, o que corrobora a afirmação anterior. Ainda com relação às diferenças encontradas para as funções de fala informação e leitura em voz alta, nota-se nos fragmentos 39 e 40 como as informações conduzem de forma peculiar o processo da atividade na Turma B, assim como a leitura em voz alta conduz o processo na Turma C.

Com relação às funções de fala interrogação, resposta e complemento de resposta, percebemos que os grupos fizeram uso similar dessas funções, com valores para a função interrogação, entre 17,5\% e 20,2\% para a Turma B e com valores próximos a $20 \%$ em cinco das seis atividades dos dois grupos da Turma C, sendo que apenas uma atividade dessa turma apresentou um valor de 15,5\%, relativamente menor do que nas demais. Com relação à função resposta, também encontramos uma tendência parecida para as duas turmas, com valores entre 9,3\% 
e 17,0\% para o grupo da Turma B e com valores entre 7,4\% e 13,1\% para os grupos da Turma C. De forma semelhante, a função de complemento de resposta mostrou valores entre 2,6\% e 4,8\% para o grupo da Turma B e valores entre 4,1\% e 6,1\% para cinco das seis atividades dos grupos da Turma C. Assim como apontado anteriormente, uma atividade da Turma C apresentou valor destoante das demais, sendo ele de $9,3 \%$.

Os valores citados revelam que as atividades colaborativas empreendidas tiveram caráter objetivo. Dessa forma, os alunos apresentaram uma postura de busca à resolução das mesmas, como pode ser observado no Quadro 26, que apresenta trechos do mapa analítico da primeira atividade dos Grupos 3 e 4 da Turma C e da primeira atividade do Grupo 1 da Turma B. Nele são apresentados três fragmentos que evidenciam a forma como as funções de fala do tipo interrogação, resposta e complemento de resposta se interligam para permitir que os alunos elaborem suas respostas de forma colaborativa.

Quadro 26 - Trechos do mapa analítico das interações ocorridas na primeira atividade do Grupo 1 da Turma B (Fragmento 41) e na primeira atividade dos Grupos 3 e 4 da Turma C (Fragmentos 42 e 43).

\begin{tabular}{|c|c|c|c|}
\hline $\mathbf{N}^{\circ}$ & $\begin{array}{l}\text { Função } \\
\text { de fala }\end{array}$ & Fragmento 41 & Agente \\
\hline 356 & Int & Você fez só olhando o caderno, deu para fazer? & A3 \\
\hline 357 & Res & Eu estava em dúvida e peguei o livro que ele passou. & A1 \\
\hline 358 & C-Res & O Avery. & A2 \\
\hline 359 & Int & É bom? & A3 \\
\hline 360 & Res & Para essa parte de mecanismo ele dá uma explicada, passo a passo. & A1 \\
\hline $\mathbf{N}^{\circ}$ & $\begin{array}{l}\text { Função } \\
\text { de fala }\end{array}$ & Fragmento 42 & Agente \\
\hline 391 & Int & Mas e aí, como é que a gente vai escrever? & A1 \\
\hline 392 & Org-I & A gente fala que a água serve como parâmetro. & A3 \\
\hline 393 & Res & Para alguns resultados. & A2 \\
\hline 394 & Int & Como? & A1 \\
\hline 396 & C-Res & É só um referencial. & A2 \\
\hline $\mathbf{N}^{\circ}$ & $\begin{array}{l}\text { Função } \\
\text { de fala }\end{array}$ & Fragmento 43 & Agente \\
\hline 22 & Int & Será que é essa que a entropia está sempre aumentando? & A3 \\
\hline 23 & Res & Acho que é. & A4 \\
\hline 24 & C-Res & É o que ele colocou na transparência. & A4 \\
\hline 25 & C-Res & É o que estava no slide, na transparência. & A2 \\
\hline
\end{tabular}

Pode-se verificar nos fragmentos 41 a 43 como as funções interrogação, resposta e complemento de resposta são usadas de forma semelhante no Grupo 1 
da Turma B e nos Grupos 3 e 4 da Turma C. Por meio delas os alunos partem de uma interrogação que exige uma resposta direta, a qual é interligada por um ou mais complementos de resposta. A interligação dessas funções permite que as atividades sejam conduzidas de forma colaborativa em todos os grupos, o que revela que, mesmo em disciplinas diferentes, o PLTL tende a levar os alunos a trabalhar de forma semelhante.

Os resultados para as funções do primeiro bloco também revelam que, apesar de os valores encontrados permitirem traçar uma comparação coerente entre as atividades das duas turmas, existem alguns valores que não se alinham com os demais para os três grupos: caso do valor de 9,3\% para a função complemento de resposta da primeira atividade do Grupo 4 da Turma C, por exemplo. Este é maior que o dobro de outros cinco resultados encontrados para mesma função, assim como o valor de $0,6 \%$ para a função de leitura em voz alta da segunda atividade do Grupo 1 da Turma $B$, que se mostrou inferior à metade de todos os outros valores encontrados para mesma função.

Conforme ilustra o Quadro 23, para as funções de fala que compõem o segundo bloco (organização de ação, experiencial, julgamento, avaliação e afetiva), nos grupos da Turma C a somatória apresentou valores entre 23,3\% e 26,7\% para o Grupo 3 e valores entre 26,5\% e 28,9\% para o Grupo 4. Para o Grupo 1 da Turma B encontramos somatória entre $32,6 \%$ e $33,8 \%$.

Percebe-se que os valores encontrados para as atividades da Turma B foram um pouco superiores aos encontrados para a Turma C. Essa pequena diferença teve como fator preponderante o uso da função avaliação pelos alunos da Turma B. De fato, as três maiores porcentagens de ocorrência no que diz respeito à função avaliação foram localizadas na Turma B $(5,4 \%, 7,8 \%$ e $8,5 \%)$, enquanto o maior valor encontrado para a Turma C foi de 4,1\%. Provavelmente, essa superioridade relaciona-se com a natureza da atividade realizada na disciplina. Conforme indicado no tópico Percurso Metodológico, constava como parte da atividade dessa turma a escolha dos exercícios mais complexos da lista disponibilizada em sala de aula pelo professor. Assim, para a realização dessa etapa os alunos usaram a função de fala do tipo avaliação com o intuito de demonstrar as suas impressões, avaliando os exercícios e as informações apresentadas pelos seus pares dentro da atividade. 
O Quadro 27 apresenta trechos do mapa analítico da segunda atividade do Grupo 1 da Turma B. Nele são apresentados dois fragmentos que evidenciam a forma como a função de fala avaliação é utilizada.

Quadro 27 - Trechos do mapa analítico das interações ocorridas na segunda atividade do Grupo 1 da Turma B (Fragmentos 44 e 45).

\begin{tabular}{|c|c|l|c|}
\hline $\mathbf{N}^{\circ}$ & $\begin{array}{c}\text { Função } \\
\text { de fala }\end{array}$ & \multicolumn{1}{|c|}{ Fragmento 44 } & Agente \\
\hline 106 & Ava & Eles (os exercícios) não parecem complicados. & A5 \\
\hline 107 & Ava & Esses primeiros (exercícios), eu achei tranquilos. & A3 \\
\hline 108 & Inf & Os três primeiros (exercícios) são iguais. & A2 \\
\hline 109 & Ava & Geralmente os primeiros exercícios são mais fáceis. & A5 \\
\hline 110 & Ava & Eu achei o exercício seis trabalhoso e o nove. & A3 \\
\hline $\mathbf{N}^{\circ}$ & $\begin{array}{c}\text { Função } \\
\text { de fala }\end{array}$ & & Agente \\
\hline 141 & Ava & Esses (exercícios) são os mais chatos. & 45 \\
\hline 142 & Int & Está todo mundo com dúvida no exercício três? & A5 \\
\hline 143 & Org-A & Porque senão a gente resolve aqui e vê se bate. & A5 \\
\hline 144 & Ava & Nossa! Que estranho esse nove! & A1 \\
\hline 145 & Jul & É isso que eu ia falar, cara. & A2 \\
\hline
\end{tabular}

No fragmento 44 os alunos A5 e A3 fazem uma avaliação dos exercícios da lista, indicando quais acham mais fáceis. Em seguida, o aluno A2 apresenta uma informação, que é complementada pela avaliação apresentada pelo aluno A5. Por fim, o aluno A3 fecha o trecho com outra avaliação, agora indicando quais exercícios são considerados mais trabalhosos. Já o fragmento 45 é iniciado com o aluno A5 fazendo uma avaliação dos exercícios da atividade. Partindo dessa avaliação, ele tenta organizar a atividade por meio de uma interrogação, que é seguida por uma orientação que busca coordenar a ação dos seus pares. O trecho é finalizado com uma avaliação exposta pelo aluno $\mathrm{A} 1$, a qual é corroborada pela concordância apresentada pelo aluno A2, por meio da função de julgamento. É nessa perspectiva que a função de fala avaliação direciona as interações discursivas e as atividades do grupo, justificando os resultados encontrados.

Para as funções de fala do tipo experiencial, julgamento e afetiva encontramos valores semelhantes para as duas turmas. Para a função de fala afetiva foram encontrados resultados pouco expressivos para as duas turmas, na sua maioria, inferiores a $1,5 \%$ para todos os grupos. Para a função de fala do tipo experiencial, encontramos valores entre 4,0\% e 7,6\% para os três grupos das duas turmas, o que mostra que os alunos encontraram um ambiente seguro para interagir com seus 
pares. Corrobora esta afirmação os valores encontrados para a função do tipo julgamento, com valores entre $7,2 \%$ e 13,2\% para os três grupos das duas turmas, mostrando que os alunos participaram de uma atividade em que se sentiram à vontade para julgar as ações realizadas pelos seus pares, como será ilustrado a seguir.

O Quadro 28 apresenta trechos do mapa analítico da segunda atividade do Grupo 1 da Turma B e da segunda atividade do Grupo 3 da Turma C. Nele são apresentados fragmentos que evidenciam a forma similar como as funções de fala julgamento e experiencial foram usadas pelos grupos.

Quadro 28 - Trechos do mapa analítico das interações ocorridas na segunda atividade do Grupo 1 da Turma B (Fragmento 46) e na segunda atividade do Grupo 3 da Turma C (Fragmento 47).

\begin{tabular}{|c|c|l|c|}
\hline $\mathbf{N}^{\circ}$ & $\begin{array}{c}\text { Função } \\
\text { de fala }\end{array}$ & \multicolumn{1}{|c|}{ Fragmento 46 } & Agente \\
\hline 59 & Exp & É essa lista, me deixou muito confuso. & $\mathrm{A} 2$ \\
\hline 60 & Exp & Porque eu fiz as listas antigas e essa era a quatro também. & $\mathrm{A} 3$ \\
\hline 61 & Exp & Eu nem olhei. & $\mathrm{A} 4$ \\
\hline 62 & Exp & Eu nem vi que era a lista quatro. & $\mathrm{A} 1$ \\
\hline 63 & Cit-C & Droga, velho, agora vou ter que dar uma olhada depois. & $\mathrm{A} 2$ \\
\hline 64 & Int & O quê? & $\mathrm{A} 5$ \\
\hline 65 & Jul & Verdade. & $\mathrm{A} 5$ \\
\hline $\mathbf{N}^{\circ}$ & $\begin{array}{c}\text { Função } \\
\text { de fala }\end{array}$ & & Fragmento 47 \\
\hline 95 & Int & É aquilo lá que (o docente) falou na aula passada? & $\mathrm{A} 2$ \\
\hline 96 & Res & É. & $\mathrm{A} 1$ \\
\hline 97 & Jul & É sim. & $\mathrm{A} 2$ \\
\hline 98 & Org-A & $\begin{array}{l}\text { Preciso achar a lei de Le Chatelier, a definição de equilíbrio e e } \\
\text { relacionar. }\end{array}$ & $\mathrm{A} 2$ \\
\hline 99 & Int & Qual que era a do Le Chatelier? & $\mathrm{A} 1$ \\
\hline 100 & Exp & Eu não sei a três, ponto de equivalência e padrão primário. & $\mathrm{A} 3$ \\
\hline
\end{tabular}

Nos fragmentos 46 e 47 percebe-se como os alunos, em determinados momentos, expõem suas experiências, o que leva seus pares a apresentarem julgamento sobre o que é exposto. Como ilustra o fragmento 46, o aluno A2 expõe para seus colegas a dificuldade encontrada com a atividade, o que leva outros três alunos (A1, A3 e A4) a fazer o mesmo. Em seguida, o aluno A2 sente-se à vontade para fazer uma citação crítica, que culmina com o julgamento feito pelo aluno A5. Já o fragmento 47 inicia-se com uma interrogação suscitada pelo aluno A2, que posteriormente gera uma resposta, um julgamento e uma organização de ação. Em seguida, frente ao exposto, o aluno A1 faz uma interrogação que indica sua falta de 
conhecimento sobre o Princípio de Le Chatelier. Por fim, o aluno A3 expõe quais conteúdos ele não domina. Fragmentos como os apresentados mostram que os alunos se sentiram à vontade para apresentar suas experiências e também se sentiram aptos para fazer julgamentos sobre seus pares.

Para a função organização de ação encontramos valores entre 5,5\% e 9,8\% para a Turma B e valores entre 7,0\% e 8,3\% para o Grupo 3 e entre 8,7\% e 13,9\% para o Grupo 4 da Turma C. Os valores encontrados foram semelhantes para os três grupos, com superioridade sendo apresentada pelo Grupo 4 da Turma C. De uma forma geral, o uso considerável dessa função para os três grupos indica que os alunos sentiram a necessidade de organizar a atividade e trabalharam com vistas ao alcance dos objetivos nela propostos. Ainda referente à função de organização de ação, relacionamos o uso superior feito pelo Grupo 4 com peculiaridades dos alunos que fizeram parte do grupo, tendo em vista que, em comparação ao Grupo 3, todos os demais fatores eram idênticos.

Os resultados encontrados mostram que os diferentes grupos fizeram uso similar das seguintes funções de fala do segundo bloco: afetiva, experiencial, julgamento e organização de ação. Isso nos permite inferir que a atividade colaborativa PLTL tende a levar alunos de diferentes turmas a fazer uso similar de diferentes funções e reforça os resultados encontrados para as funções de fala do primeiro bloco (interrogação, resposta e complemento de resposta). Cabe ressaltar que, assim como foi apontado nas funções de fala do primeiro bloco, aqui também se apresentaram alguns valores destoantes dos demais.

Conforme ilustra o Quadro 23, para as funções de fala que compõem o terceiro bloco (organização de ideia, citação crítica, resposta crítica e complemento de resposta crítica), a somatória para o Grupo 1 da Turma B apresentou valores entre $11,1 \%$ e $20,4 \%$. Já para os grupos da Turma C, encontramos somatória entre $21,4 \%$ e $28,8 \%$ para as atividades do Grupo 3 e somatória entre $20 \%$ e $24,2 \%$ para as atividades do Grupo 4.

Os valores encontrados para os dois grupos da Turma $C$ foram superiores aos encontrados para o grupo da Turma B. Entretanto, é preciso levar em consideração as características peculiares das disciplinas e das atividades propostas e o uso individual de cada uma das funções de fala. De fato, todas as maiores porcentagens referentes às funções resposta crítica, complemento de 
resposta crítica e organização de ideia foram localizadas nos grupos da Turma C, com valores entre $5,0 \%$ e $6,7 \%$ para a função de resposta crítica, entre $12,4 \%$ e $17,6 \%$ para a função complemento de resposta crítica e entre 2,0\% e 8,6\% para a função de organização de ideia. Já para Turma B encontramos valores inferiores para as três funções em praticamente todas as atividades.

A referida diferença mostra que os alunos da Turma $C$ foram solicitados a responder de forma mais crítica e reflexiva aos exercícios propostos. O que os levou a complementar suas respostas de forma crítica, com base em conhecimento teórico adquirido em disciplinas anteriores, assim como necessitaram organizar suas ideias para finalizar as atividades. Entretanto, essa primeira impressão é contraditória frente aos valores encontrados para a função de fala citação crítica.

Os valores encontrados para a função citação crítica para o grupo da Turma B foram superiores ao encontrados para a Turma $C$ nos dois grupos, com valores entre $6,5 \%$ e $11,4 \%$. Em contraponto, para a Turma $C$ encontramos valores entre $4,2 \%$ e $7,3 \%$ para o Grupo 3 e 2,5\% e 2,6\% para o Grupo 4.

O Quadro 29 apresenta trechos do mapa analítico da terceira e da segunda atividade do Grupo 1 da Turma B. Nele são apresentados dois fragmentos que evidenciam a forma como a função de citação crítica é usada pelo Grupo 1 da Turma B.

Quadro 29 - Trechos do mapa analítico das interações ocorridas na terceira atividade e na segunda atividade do Grupo 1 da Turma B (Fragmentos 48 e 49).

\begin{tabular}{|c|c|c|c|}
\hline $\mathbf{N}^{\circ}$ & $\begin{array}{l}\text { Função } \\
\text { de fala }\end{array}$ & Fragmento 48 & Agente \\
\hline 373 & Exp & Só sei que eu estava cansado e não prestei atenção. & A2 \\
\hline 374 & Exp & Ou sei lá. Será que ele falou? Eu nem lembro. & A5 \\
\hline 375 & Cit-C & $\begin{array}{l}\text { Eu lembro que ele colocou em uma expressão (matemática). Só que eu } \\
\text { estava cansado e não prestei atenção. }\end{array}$ & A2 \\
\hline 376 & Cit-C & $\begin{array}{l}\text { Eu também. Sei que ele colocou em uma expressão "Pezinho" e } \\
\text { colocou: "Esse é o fator estérico". }\end{array}$ & A5 \\
\hline $\mathbf{N}^{\circ}$ & $\begin{array}{l}\text { Função } \\
\text { de fala }\end{array}$ & $\begin{array}{ll}\text { Fragmento } 49 \\
\end{array}$ & Agente \\
\hline 263 & C-Res & Não precisa ser só dois. & A3 \\
\hline 264 & Org-A & Vai colocando o exercício três aqui também. & A1 \\
\hline 265 & Cit-C & $\begin{array}{l}\text { Da lista cinco eu não me lembro de ter dificuldade até o exercício cinco. } \\
\text { Aí eu vi o nove aqui e não entendi direito, por isso que eu o coloquei } \\
\text { como exercício. }\end{array}$ & A2 \\
\hline 266 & Cit-C & $\begin{array}{l}\text { Eu coloquei o nove e o dez porque parece que falta informação, não que } \\
\text { depois vai ficar fácil de fazer. }\end{array}$ & A5 \\
\hline
\end{tabular}

No fragmento 48 os alunos fazem referência a uma determinada expressão matemática e até analisam o conteúdo de forma crítica, porém a resolução do 
cálculo é feita no papel e não se tem registro disso em áudio, porque seu conteúdo tem como base a resolução matemática dos exercícios. Com isso, parte das respostas dadas com caráter de citação crítica, não é discutida oralmente e sim escrita em forma de expressões matemáticas. Além disso, a atividade permitiu que os alunos escolhessem o exercício que consideravam mais complexo, o que os levou a fazer citações críticas, como evidencia o fragmento 49. Entretanto, essas citações não exigiram respostas críticas, complementos críticos e nem mesmo organização de ideia. Para que a análise refletisse melhor os aspectos críticos nela envolvidos, teria sido necessário considerar não somente as interações discursivas, mas também o material escrito gerado em cada grupo.

A referida limitação, imposta pela metodologia de análise, não gerou impacto na Turma C. Com efeito, nessa turma, conforme mencionado anteriormente, os alunos realizaram leitura em voz alta de conteúdos necessários para o alcance das respostas mais completas, discutiram e elaboraram respostas mais críticas, que foram complementadas também de forma crítica. Ademais, existiu a necessidade de organização de ideia com o objetivo de sumarizar o que foi dito pelo grupo, como ilustra o Quadro 30.

O Quadro 30 apresenta trechos do mapa analítico da segunda atividade do Grupo 3 da Turma C. Nele são apresentados dois fragmentos que evidenciam a forma como as funções do terceiro bloco são usadas pelo Grupo 3 da Turma C.

Quadro 30 - Trechos do mapa analítico das interações ocorridas na segunda atividade do Grupo 3 da Turma C (Fragmentos 50 e 51).

\begin{tabular}{|c|c|l|c|}
\hline $\mathbf{N}^{\circ}$ & $\begin{array}{c}\text { Função } \\
\text { de fala }\end{array}$ & \multicolumn{1}{|c|}{ Fragmento 50 } & Agente \\
\hline 101 & Res-C & Ponto de equivalência é quando você termina a titulação. & $\mathrm{A} 1$ \\
\hline 102 & Int & Não é? & $\mathrm{A} 1$ \\
\hline 103 & $\mathbf{C}-$ Res-C & É ponto de virada então. & $\mathrm{A} 3$ \\
\hline 104 & Org-I & É o que a gente fala, mas é ponto de equivalência. & $\mathrm{A} 1$ \\
\hline $\mathbf{N}^{\circ}$ & $\begin{array}{c}\text { Função } \\
\text { de fala }\end{array}$ & Fragmento 51 & Agente \\
\hline 179 & Int & É que para cada mol deste tem dois desse, certo? & $\mathrm{A} 3$ \\
\hline 180 & Res & Sim. & $\mathrm{A} 1$ \\
\hline 181 & $\mathbf{C - R e s - C}$ & $\begin{array}{l}\text { Esse vai ser o produto de solubilidade, e ele só substituiu o valor dele } \\
\text { aqui em concentração de A. }\end{array}$ & $\mathrm{A} 3$ \\
\hline 182 & Int & Foi o que ele achou aqui, está vendo? & $\mathrm{A} 3$ \\
\hline 183 & Org-I & $\begin{array}{l}\text { Aí ele elevou esse aqui ao quadrado porque ele é ao quadrado, por } \\
\text { isso ficou o quatro aqui. }\end{array}$ & $\mathrm{A} 3$ \\
\hline
\end{tabular}


Nos fragmentos 50 e 51 pode-se observar como o conteúdo abordado na disciplina permite que os alunos façam inferências de teor crítico e, como apresentado no fragmento 50 , normalmente a resposta, mesmo que crítica, sempre pede uma complementação teórica que acaba mostrando um teor crítico no mesmo nível. Já no fragmento 51 existe uma diferença quanto à forma de trabalhar apontada no fragmento 48 referente à Turma B. Na disciplina em questão, a efetuação dos cálculos matemáticos ocorre de forma direta no papel. Já no fragmento 51 percebe-se que, mesmo quando os alunos fazem uso de recursos matemáticos, estes estão precedidos por conteúdo teórico da área de Química, o que gera mais uma vez uma interação que se mostra crítica.

\subsubsection{Análise das interações discursivas na perspectiva da segunda dimensão: processamento cognitivo}

A análise das interações discursivas foi realizada por meio dos três tipos de processamentos cognitivos, rotineiro, off-task e exploratório, nos mesmos moldes empregados anteriormente.

Na Figura 17 apresentamos a frequência expressa em porcentagem em que cada processamento cognitivo foi utilizado nos grupos colaborativos PLTL nas três atividades no Grupo 1 da Turma B e nas três atividades nos Grupos 3 e 4 da Turma C.

Figura 17 - Porcentagem de uso dos processamentos cognitivos durante a resolução das três atividades do Grupo 1 da Turma B (a) e das três atividades dos Grupos 3 (b) e Grupos 4 (c) da Turma C, sendo $A T 1=$ primeira atividade, $A T 2=$ segunda atividade e $A T 3=$ terceira atividade.

(a)

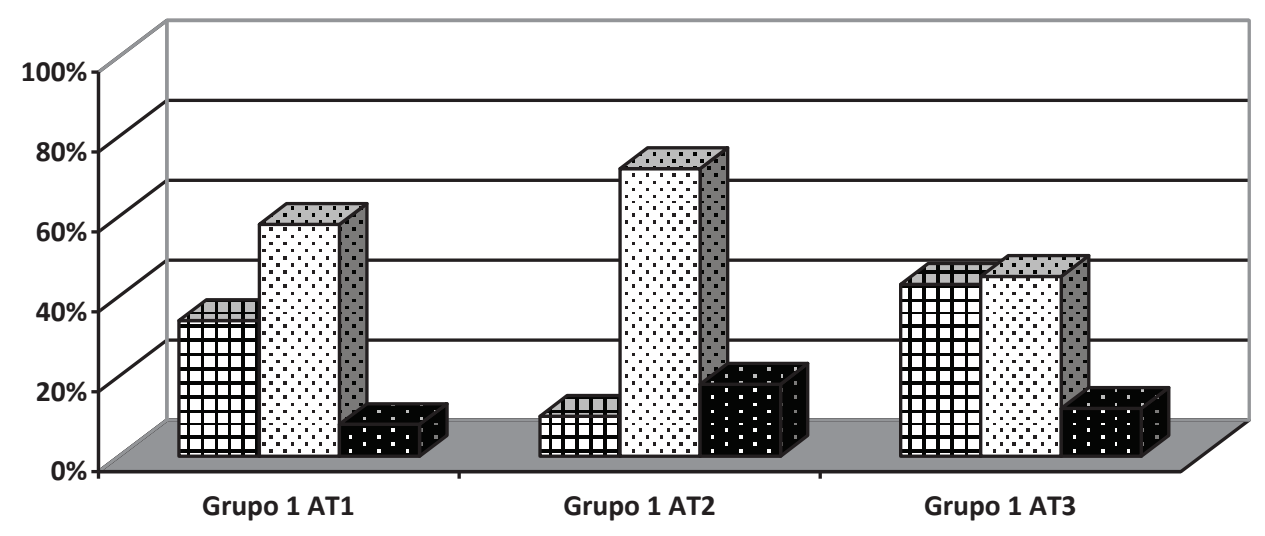


(b)
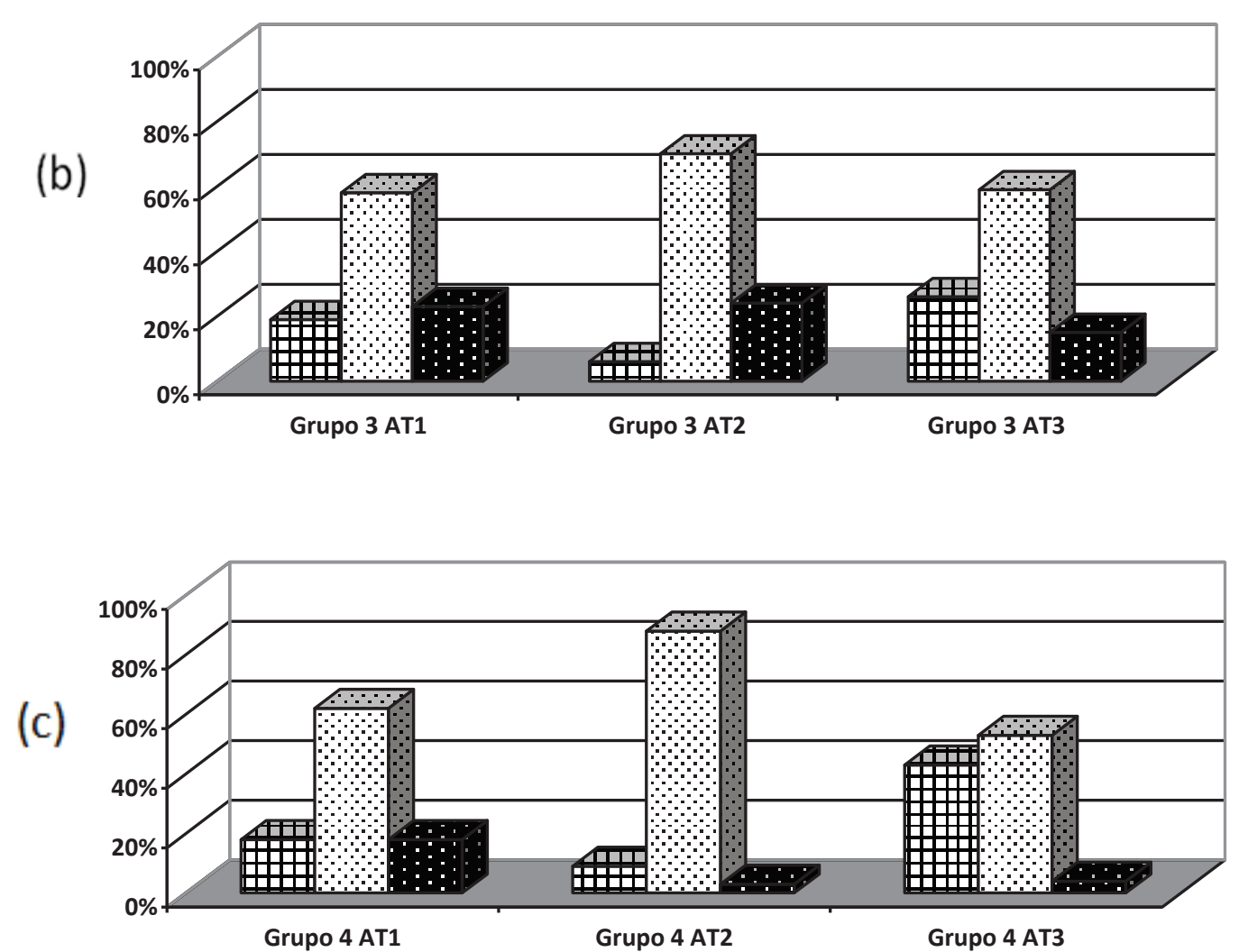

A análise da Figura 17 indica a seguinte tendência para a ocorrência dos processamentos cognitivos nos grupos: o uso do processamento cognitivo rotineiro foi superior em todos os grupos, nas três atividades das duas turmas, sendo que o menor valor apresentado foi de 45\%, na terceira atividade do Grupo 1 da Turma B, e o valor máximo foi de $88 \%$, na segunda atividade do Grupo 4 da Turma C; o processamento cognitivo off-task foi o segundo mais recorrente em cinco das nove atividades analisadas, sendo que o menor valor apresentado foi de $6 \%$, na segunda atividade do Grupo 3 da Turma C, e o valor máximo apresentado foi de 43\%, que se repetiu na terceira atividade do Grupo 1 da Turma B e na terceira atividade do Grupo 4 da Turma C; o processamento cognitivo exploratório foi o menos recorrente em cinco das nove atividades analisadas, sendo que o menor valor apresentado foi de $3 \%$, na segunda atividade do Grupo 4 da Turma C, e o valor máximo apresentado foi de $24 \%$, na segunda atividade do Grupo 3 da Turma C. Ressaltamos, ainda, os resultados encontrados na primeira atividade do Grupo 4 da Turma C, no qual encontramos valor de $19 \%$ tanto para o processamento cognitivo off-task, quanto para o processamento cognitivo exploratório. 
Com o objetivo de fazer apontamentos sobre a ocorrência dos processamentos cognitivos, os dados foram analisados de forma minuciosa. No que diz respeito ao processamento cognitivo rotineiro, observamos que os três grupos das duas turmas apresentaram valores que variaram muito no decorrer das três atividades, sendo essa variação a única tendência constatada para os três grupos das duas turmas. Dessa forma, os resultados não permitiram uma comparação que diferenciasse o uso desse processamento dentro das diferentes turmas, mas os valores elevados encontrados denotam que o trabalho realizado nas Turmas $\mathrm{B}$ e C, mesmo com variações, apresentou um caráter consideravelmente rotineiro. O que reforça os valores encontrados para as duas turmas no que diz respeito ao uso superior das funções de fala do primeiro bloco. Estas indicam que as atividades dessas turmas apresentaram características objetivas.

Os valores encontrados para o processamento cognitivo exploratório revelaram grande variação nos resultados das duas turmas. O Grupo 3 da Turma C apresentou o maior uso desse processamento com valores entre $15 \%$ e $24 \%$. Contrariamente, o Grupo 4 da mesma turma apresentou o menor uso deste processamento, com valores entre 3\% e 19\%. De forma intermediária, o Grupo 1 da Turma B apresentou valores entre $8,0 \%$ e 18\%, o que reafirma o caráter não regular das atividades colaborativas, independentemente do grupo ou da disciplina em que se esteja trabalhando. O que permite verificar, dentro de um mesmo grupo, atividades com caráter exploratório variável. Cabe novamente destacar os valores reportados para as funções de fala do terceiro bloco, que apontavam as atividades do Grupo 1 da Turma B como menos crítica do que as do Grupo 4 da Turma C. Esses valores são contraditórios na análise da segunda dimensão, que mostra a atividade da Turma B com um caráter mais exploratório. Essa aparente incoerência será analisada a seguir.

O Quadro 31 apresenta trechos do mapa analítico da primeira e da segunda atividade do Grupo 1 da Turma B. Nele constam dois fragmentos que evidenciam uma forma peculiar de atividade com caráter exploratório. 
Quadro 31 - Trechos do mapa analítico das interações ocorridas na primeira e segunda atividade do Grupo 1 da Turma B (Fragmentos 52 e 53).

\begin{tabular}{|c|c|l|c|c|}
\hline $\mathbf{N}^{\circ}$ & $\begin{array}{c}\text { Função } \\
\text { de fala }\end{array}$ & \multicolumn{1}{|c|}{ Fragmento 52 } & & Agente \\
\hline 118 & Exp & $\begin{array}{l}\text { Na (questão) dois eu não justifiquei, porque ele não fala } \\
\text { nada, eu só vi qual que é. }\end{array}$ & PCE & A1 \\
\hline 119 & Org-A & É que a gente vai ter que justificar. & PCE & A3 \\
\hline 120 & Ava & Isso é difícil, às vezes. & PCR & A4 \\
\hline 121 & Cit-C & É difícil justificar qual é mais difícil e complexo. & PCE & A2 \\
\hline 122 & Cit-C & $\begin{array}{l}\text { O que que ele está fazendo aqui? Ele está vendo qual que é } \\
\text { o K, qual que é o K-1 } \text {, tudo isso nada mais é do que equação } \\
\text { diferencial. }\end{array}$ & PCE & A5 \\
\hline $\mathbf{N}^{\circ}$ & $\begin{array}{l}\text { Função } \\
\text { de fala }\end{array}$ & Fragmento 53 & & Agente \\
\hline 143 & Org-A & Porque senão a gente resolve aqui e vê se bate. & PCE & A5 \\
\hline 147 & Org-A & É, precisa explicar o que está acontecendo. & PCE & A2 \\
\hline 148 & Cit-C & Também olha de onde é. Do Laidler. & PCE & A3 \\
\hline 149 & Org-A & Deixa eu ver rapidinho. & PCE & A5 \\
\hline
\end{tabular}

Nos fragmentos 52 e 53 observa-se como, usando funções de fala que não apresentam características críticas, os alunos são capazes de explorar a atividade buscando respostas mais completas. No fragmento 52, cinco alunos interagem usando as funções de fala experiencial, avaliação e organização de ação, que fazem parte das funções do segundo bloco referentes à interação. Em seguida, eles fazem uso, por duas vezes, da função citação crítica, que faz parte do terceiro bloco. Assim, mesmo usando mais funções de interação do que funções críticas, as diferentes funções direcionam os alunos a explorar a atividade e exige dos membros do grupo uma melhor resposta, como é evidenciado na frase do aluno A3: É que a gente vai ter que justificar. Essa frase exige uma reflexão que leva os alunos às citações críticas e à exploração da temática.

De forma similar, no fragmento 53 três alunos usam a função de fala organização de ação, que faz parte do segundo bloco de análise, de forma evidentemente exploratória. Nele o aluno A5 sugere a resolução dos diversos exercícios com o objetivo de avançar na sua compreensão. Em um segundo momento, o aluno A2 sugere que responder de forma direta não é suficiente, sendo necessário fazer uma explicação. Após uma citação crítica, o fragmento encerra-se com o aluno A5 sugerindo que teria aceitado o desafio, pedindo para verificar o exercício. Essas e outras passagens evidenciam que não necessariamente só uma função crítica é capaz de levar os alunos a uma atividade com caráter exploratório. 
Por fim, ao analisarmos comparativamente a frequência do processamento cognitivo off-task, verificamos valores variáveis para as duas turmas, com os três grupos passando por valores mínimos e máximos no decorrer das três atividades. Apontamos que, mesmo dentro dessa oscilação, os três grupos apresentaram uma tendência quando verificamos as atividades de forma sequencial. Assim, os maiores valores para esse processamento foram encontrados na terceira atividade para todos os grupos. Para os grupos da Turma $C$, encontramos para a terceira atividade os valores de $26 \%$ para o Grupo 3 e de $43 \%$ para o Grupo 4. Já para a Turma B, encontramos para a terceira atividade o valor de $43 \%$. O uso elevado desse processamento na terceira atividade de forma similar para os três justifica-se, provavelmente, pelo seu caráter finalizador, o que leva os alunos a apresentar um comportamento mais descontraído na última atividade do que nas demais, aumentando assim o uso do processamento off-task.

\subsubsection{Análise das interações discursivas na perspectiva da terceira dimensão: processamento social}

A análise dos quatro tipos de processamentos sociais (colaborativo, tutorial, individualista e competitivo) foi realizada nos mesmos moldes empregados anteriormente.

Com base nas informações contidas nos mapas analíticos, identificamos as interações dominantes ocorridas no decorrer da resolução das três atividades do Grupo 1 da Turma B e do Grupo 3 e Grupo 4 da Turma C. A Figura 18 ilustra os tipos de interações sociais considerados, assim como a porcentagem em que cada um foi utilizado.

Figura 18 - Porcentagem de uso dos processamentos sociais durante a resolução das três atividades do Grupo 1 da Turma B (a) e das três atividades do Grupo 3 (b) e Grupo 4 (c) da Turma C, $A T 1=$ primeira atividade, $A T 2=$ segunda atividade e $A T 3=$ terceira atividade.

(a)

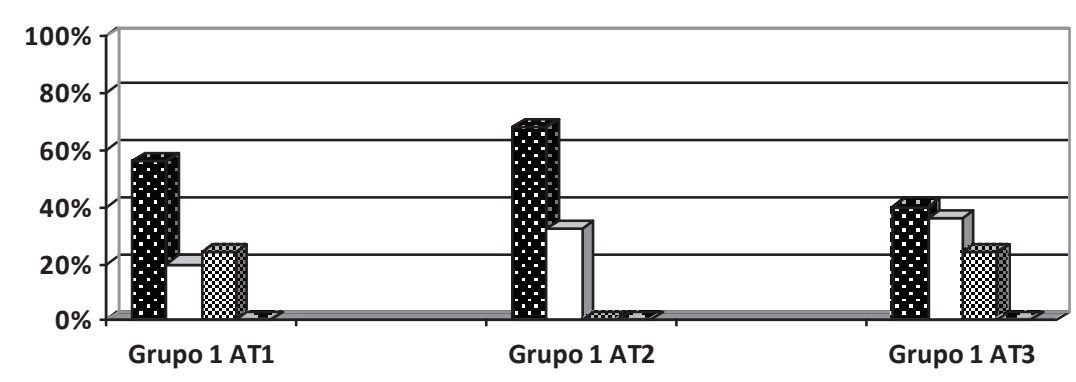


(b)
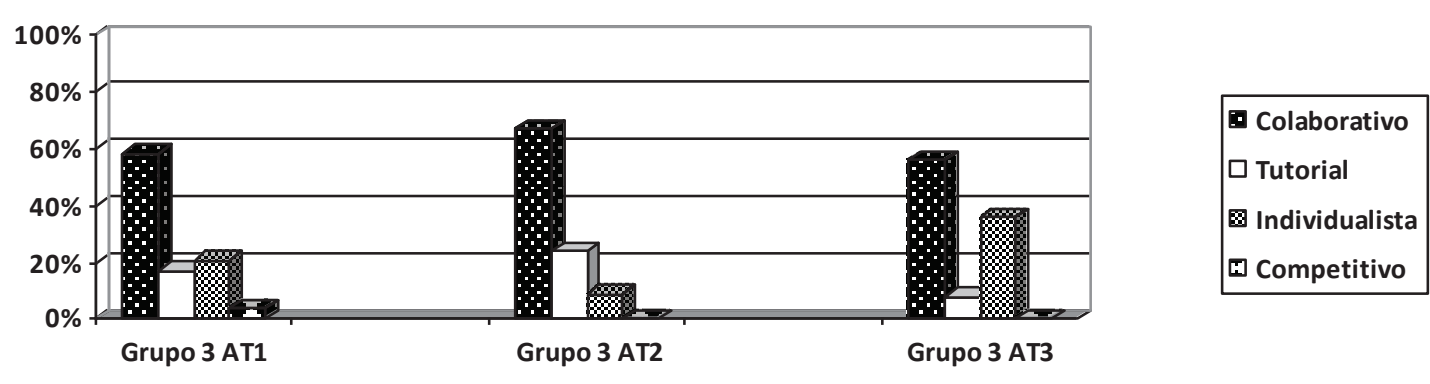

(c)

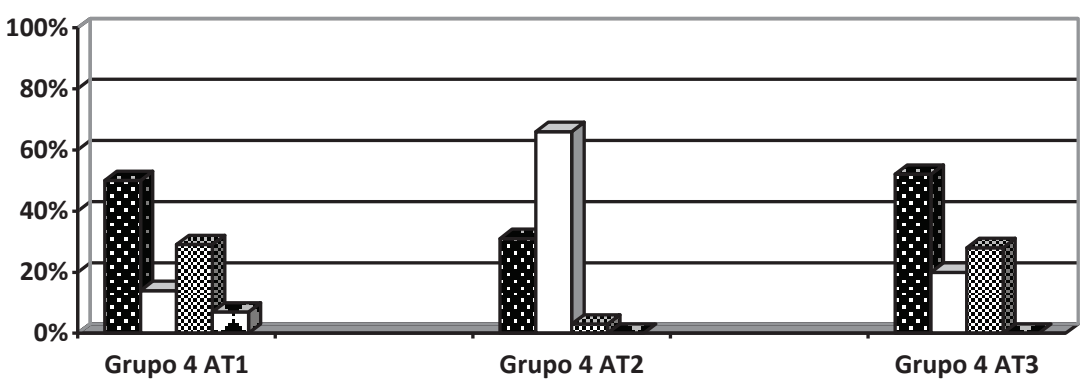

\begin{tabular}{|l|}
\hline Colaborativo \\
$\square$ Tutorial \\
囚 Individualista \\
$\square$ Competitivo \\
\hline
\end{tabular}

Tanto na Turma B quanto na Turma $\mathrm{C}$ o processamento social predominante em praticamente todas as atividades foi do tipo colaborativo, com valores entre $40 \%$ e $68 \%$ para as atividades da Turma B, e valores entre $31 \%$ e $67 \%$ para as atividades dos Grupos 3 e 4 da Turma C. Destacamos que a segunda atividade do Grupo 4, que apresentou o valor de $31 \%$ de processamento social do tipo colaborativo, foi a única que não teve esse tipo de processamento social como predominante. Os valores revelam que, de uma forma geral, as atividades das duas turmas tiveram a colaboração como característica social principal.

Com relação ao uso dos processamentos dentro das três atividades, o processamento social colaborativo apresentou valores variáveis, de forma semelhante ao verificado na análise da segunda dimensão. O que não permitiu a definição de uma tendência em sua frequência para nenhum dos três grupos, reforçando a ideia sobre o caráter da disciplina não ser relevante na dinâmica das interações estabelecidas nos grupos PLTL.

O segundo processamento social em destaque foi o do tipo tutorial. Este apresentou resultados significativos e bem variados para praticamente todos os grupos, com valores entre $8 \%$ e $24 \%$ para o Grupo 3 e valores entre $14 \%$ e $66 \%$ para o Grupo 4 da Turma C. Já para o Grupo 1 da Turma B foram encontrados valores entre $20 \%$ e $36 \%$. Essa variação está de acordo com os resultados 
encontrados nas demais dimensões, que mostrou a inexistência de uma tendência no trabalho dos grupos das duas turmas. Chama a atenção os valores encontrados para esse processamento social para a Turma $B$, na qual verificamos um aumento gradativo no decorrer da primeira para a terceira atividade, revelando uma boa interação entre o grupo e o líder-par dessa turma, resultado que não foi igualmente encontrado na Turma C.

O Quadro 32 apresenta um trecho do mapa analítico da terceira atividade do Grupo 1 da Turma B. Nele consta o fragmento 54, que evidencia a forma como os alunos interagem dentro do grupo.

Quadro 32 - Trecho do mapa analítico das interações ocorridas na terceira atividade do Grupo 1 da Turma B (Fragmento 54).

\begin{tabular}{|c|l|l|c|c|}
\hline $\mathbf{N}^{\circ}$ & $\begin{array}{l}\text { Função } \\
\text { de fala }\end{array}$ & \multicolumn{1}{|c|}{ Fragmento 54 } & Agente \\
\hline 106 & & Parabéns. & PCO & A4 \\
\hline 107 & & Obrigado. & PCO & A5 \\
\hline 108 & & $\begin{array}{l}\text { Eu estava esperando você chegar para te dar parabéns. Eu } \\
\text { queria te dar parabéns. }\end{array}$ & PCO & A4 \\
\hline 109 & & Que mentira. & PCO & A1 \\
\hline 110 & & $\begin{array}{l}\text { É verdade, pode ver que eu ainda não te mandei nada. Eu sabia } \\
\text { que iria te encontrar hoje à noite. }\end{array}$ & PCO & A4 \\
\hline 111 & & Vinte e dois anos, agora eu sou um idoso. & PCO & A5 \\
\hline 112 & & Você está ficando velho. & PCO & A4 \\
\hline
\end{tabular}

No fragmento 54 percebe-se como os alunos A4, A5 e A1 interagem de forma amistosa dentro da atividade. Nele o aluno A5 recebe os parabéns pelo seu dia de aniversário, o que mostra o grau de intimidade entre os alunos. Depois dos parabéns, o trecho segue com os alunos interagindo de forma bem amigável e até afetiva. Esse grau de intimidade pode ser reflexo direto do tempo em que estudam juntos, uma vez que estão no sexto semestre do Curso. O que, se por um lado aumenta a intimidade entre os alunos, diminui a chance de competirem ou apresentarem comportamentos que não sejam colaborativos, justificando os resultados encontrados.

A discussão dos dados apresentados até o momento fornece subsídios para que possamos fazer considerações sobre a nossa segunda questão de pesquisa: de que forma a natureza específica da disciplina pode influenciar na dinâmica das interações discursivas em um grupo colaborativo PLTL? 
Observamos que o fato dos alunos da Turma $\mathrm{C}$ terem lidado nos grupos colaborativos PLTL com atividades que versavam sobre Equilíbrio Químico, conteúdo de grande complexidade no contexto do ensino de Química (CABORIN; SERRANO, 2007), exigiu que se empenhassem em discussões críticas e embasadas permitindo que lançassem mão de conhecimentos dos quais já eram detentores no nível médio de ensino ou que estavam disponíveis nos livros didáticos da disciplina (ATKINS; JONES, 2006; MAHAN; MYERS, 1995) para o alcance dos seus objetivos. Dessa maneira, as interações discursivas foram pautadas no uso das funções de fala do terceiro bloco, acionadas pelos alunos por meio das citações, respostas e complementos de resposta crítica, entretanto, para esta turma também tivemos o uso considerável das funções do primeiro e do segundo bloco. Nessa perspectiva, ressaltamos o uso da função de fala do tipo leitura em voz alta pelos grupos da Turma $\mathrm{C}$, pois como exposto anteriormente, era imprescindível a leitura dos livros indicados pelo docente para alcance de respostas às questões teóricas propostas.

O processamento cognitivo predominante observado foi o rotineiro, que sobrepuja o processamento cognitivo exploratório em todas as atividades, apresentando como característica marcante a variação nos valores encontrados para os dois processamentos, com atividades apresentando valores entre 2,5 vezes e 29 vezes maiores para o processamento rotineiro. Constatação que mostra uma relação não tão harmoniosa entre as funções de falas usadas e o processamento cognitivo predominante. De forma similar, para o processamento cognitivo exploratório encontramos grande variação quando comparamos os dois grupos e até mesmo dentro das atividades de um mesmo grupo. Os resultados para o processamento exploratório reforçaram a ideia de ausência de conexão entre as funções de fala e o processamento cognitivo no caso dos grupos PLTL, isto porque percebe-se que o uso considerável das funções do terceiro bloco não garantiram um elevado uso do processamento cognitivo exploratório. O processamento cognitivo off-task tornou-se mais recorrente nas atividades finais, frente às iniciais. Acreditamos que esta tendência está interligada, até certo ponto com o caráter finalizador, o que leva os alunos a apresentarem um comportamento mais descontraído na última atividade do que nas demais, aumentando assim o uso do processamento off-task. 
Os quatro processamentos sociais foram encontrados para os dois grupos da Turma C, com valores bem variados, dentre eles destacamos o processamento colaborativo dominante nas três atividades do Grupo 3. No Grupo 4 destacamos o processamento social tutorial, que na segunda atividade apresentou valores superiores aos do processamento social colaborativo. Nas demais atividades esse processamento se fez presente, mas com valores variáveis. Resultado esperado já que a estrutura colaborativa PLTL contava com a participação do líder-par que dentro da atividade muitas vezes realizava o papel de tutor. Destacamos a presença do processamento individualista recorrente nas seis atividades e a presença do processamento social competitivo relatado na primeira atividade dos dois grupos. Mesmo assim, ressaltamos que os valores para os processamentos colaborativo e tutorial nos dois grupos indicam que, de uma forma geral, as atividades se mostraram colaborativas o que indica que os resultados alcançados foram satisfatórios.

O fato dos alunos da Turma B terem lidado nos grupos colaborativos PLTL com atividades baseados em um conjunto de conceitos relativos a cálculos matemáticos, envolvendo diferentes formas de pensar a Matemática articulada com os conhecimentos de Química e suas características peculiares, permitiu que lançassem mão de conhecimentos dos quais já eram detentores de outras disciplinas cursadas em anos anteriores para o alcance dos seus objetivos. Entretanto, a criticidade frente a tais conhecimentos não foi evidenciada nas interações discursivas, pois as funções do terceiro bloco não foram privilegiadas. As interações foram, na sua maioria, pautadas no uso das funções de fala do primeiro bloco, acionadas pelos alunos na intenção de alcançar respostas diretas. Em segundo plano apareceram funções de fala do segundo bloco e, por último, funções do terceiro bloco. No entanto, este resultado discrepante foi interpretado como sendo devido a uma fragilidade da metodologia de análise empregada, que não registrava parte das respostas dadas de caráter crítico, uma vez que elas eram diretamente escritas pelos alunos em forma de expressões matemáticas e não comentadas oralmente.

Diante de tal interpretação, assumimos que a distribuição das funções de fala nos grupos PLTL de ambas as disciplinas (ministrada na Turma B e C) foi bastante semelhante, nos oferecendo indicativo de que a natureza da disciplina 
pouco influencia na dinâmica das interações discursivas em um grupo colaborativo desse tipo.

O processamento cognitivo predominante observado foi o rotineiro nas três atividades, porém seu uso se mostrou muito irregular na passagem da primeira para a terceira atividade, resultado que se repetiu para os outros dois processamentos. Assim, é possível especular sobre o caráter não regular dos processamentos cognitivos nos grupos PLTL, independentemente da disciplina em que se esteja trabalhando, uma vez que este comportamento foi observado nas duas turmas em todos os grupos.

Com relação ao processamento social, não se verificou a ocorrência do tipo competitivo e o processamento social do tipo individualista foi registrado em duas das três atividades. Entretanto, seu efeito sobre a atividade foi amenizado pelo significativo comportamento com características colaborativa, acompanhada de um aumento gradativo no processamento social tutorial.

A partir da investigação da dinâmica das interações discursivas estabelecidas entre os alunos nos grupos colaborativos PLTL, ainda é possível destacar algumas potencialidades das atividades desenvolvidas em tais contextos.

Como verificado por Hong (2010), alguns sentimentos como ansiedade podem levar os alunos a ter uma visão negativa frente o ensino de Ciências. Assim, o autor aponta como alternativa para motivar os alunos e diminuir a sua ansiedade o uso de estratégias nas quais eles trabalham de forma colaborativa. Tal potencialidade foi também mostrada a partir dos nossos resultados, considerando os valores significativos obtidos com relação ao processamento social colaborativo e ao processamento cognitivo off-task na maioria das atividades. Ou seja, os alunos de ambas as turmas desfrutaram de ambiente descontraído, que lhes permitiu ainda fazer uso substancial das funções do segundo bloco: avaliação julgamento, organização de ação e experiencial.

O trabalho de Preszler (2009) enfatiza o aprimoramento do desempenho acadêmico de alunos de Biologia participantes de grupos colaborativos semelhantes ao PLTL. Conforme esclarecemos anteriormente, embora o nosso objetivo não tenha sido o de investigar o desempenho acadêmico dos alunos a partir da estratégia adotada, acreditamos que a recorrência das funções de fala do terceiro bloco nos grupos da Turma $\mathrm{C}$ e da Turma $\mathrm{B}$, somado aos valores encontrados para 
o processamento cognitivo do tipo exploratório corroboram o estudo do referido autor. Nessa perspectiva, destacamos a potencialidade da estratégia PLTL na promoção de aprendizagem de conteúdos de Química.

Ainda com relação ao potencial das atividades colaborativas na promoção da aprendizagem de conceitos científicos, citamos os resultados apontados por Costa, Oliveira e Alves (2008). Os autores discutem a influência positiva das interações com os pares nos grupos na aprendizagem e revisão de conceitos, principalmente nos momentos em que os alunos precisam esclarecer os próprios pontos de vistas. O elevado uso de funções do segundo bloco de análise por parte dos sujeitos da nossa pesquisa, as quais indicam o posicionamento dos alunos frente ao seu trabalho e ao trabalho dos seus pares, está alinhado com as considerações dos mesmos.

She (1999) aponta o desenvolvimento de habilidades interpessoais, entre elas a habilidade de comunicação, por parte dos alunos a partir da realização de atividades em grupos colaborativos em aulas de laboratório de Ciências, enquanto Ribeiro e Echeverría (2009), ao se referirem ao mesmo tipo de grupo, tratam da sua potencialidade em tornar o ambiente universitário mais seguro e acolhedor para os alunos calouros, fazendo com que se envolvam e se adaptem mais rapidamente ao ambiente universitário. Os valores elevados encontrados para o processamento social do tipo colaborativo em todos os grupos nas Turmas B e C corroboram as observações dos autores com relação à potencialidade da estratégia no desenvolvimento da comunicação e de um ambiente mais acolhedor. Além disso, a recorrência de funções de fala do tipo experiencial nas duas turmas sugere que estes se sentem à vontade para interagir com seus pares em grupos dessa natureza.

\subsection{Influência do grau de estrutura da atividade de pequeno grupo na dinâmica das interações discursivas em uma mesma disciplina}

As interações discursivas estabelecidas nos grupos cooperativos jigsaw e nos grupos colaborativos PLTL na Turma C foram analisadas com base em três dimensões: função de fala, processamento cognitivo e processamento social. Cada uma dessas funções será analisada a seguir separadamente. 
Cabe destacar que a análise realizada no tópico 5.1 abordou as interações estabelecidas apenas nos grupos de base do jigsaw, nos quais foram realizadas a primeira e a terceira atividade, já que naquele contexto tínhamos como objetivo comparar os grupos base originais de duas turmas diferentes, não sendo assim necessário investigar as interações nos grupos de especialistas. Como o objetivo do presente tópico é analisar as diferenças entre duas estratégias distintas, torna-se importante averiguar as interações ocorridas dentro dos grupos de especialistas, assim como sua influência nos grupos de base. Para maior clareza, os grupos de especialistas serão identificados nos gráficos a seguir como Grupo EAT2, dessa forma indicamos em que momento eles aconteceram e também que sua formação é diferente dos demais.

\subsubsection{Análise das interações discursivas na perspectiva da primeira dimensão: função de fala}

Seguindo o modelo dos tópicos anteriores, com o intuito de facilitar a análise das interações discursivas na perspectiva das funções de fala, estas foram distribuídas em três blocos.

No Quadro 33, apresentamos a frequência expressa em porcentagem em que cada função de fala foi utilizada nos grupos cooperativos jigsaw e nos grupos colaborativos PLTL na Turma C, para cada bloco de análise. Nele apresentamos os dados obtidos para o Grupo 1 e para o Grupo 2 nas três atividades cooperativas (primeira e terceira atividades realizadas nos grupos de base e segunda atividade no grupo de especialistas) e apresentamos os dados obtidos para o Grupo 3 e para o Grupo 4 nas três atividades colaborativas. 
Quadro 33 - Distribuição das funções de fala para os grupos cooperativos e para os grupos colaborativos nas atividades da Turma C.

\begin{tabular}{|l|c|c|c|c|c|c|c|c|c|c|c|c|}
\cline { 2 - 15 } \multicolumn{1}{c|}{} & \multicolumn{9}{|c|}{ Cooperativos } & \multicolumn{5}{c|}{ Colaborativos } \\
\cline { 2 - 16 } & Grupo 1 e 2 & $\begin{array}{c}\text { Grupo de } \\
\text { Especialistas }\end{array}$ & \multicolumn{1}{c|}{ Grupo 1 e 2 } & \multicolumn{3}{c|}{ Grupo 3 } & \multicolumn{3}{c|}{ Grupo 4 } \\
\cline { 2 - 16 } & AT1 & AT1 & AT2 & AT2 & AT3 & AT3 & AT1 & AT2 & AT3 & AT1 & AT2 & AT3 \\
\hline Int & 21,9 & 17,1 & 22,3 & 21,6 & 21,2 & 20,6 & 23,2 & 22,2 & 26,4 & 20,1 & 15,5 & 21,9 \\
\hline Res & 8,9 & 9,9 & 14,3 & 12,9 & 11,5 & 13 & 11,9 & 11,4 & 13,1 & 10,8 & 7,4 & 10,3 \\
\hline C-Res & 1,0 & 9,3 & 1,7 & 3,7 & 2,6 & 2,3 & 4,4 & 4,1 & 4,7 & 9,3 & 6,1 & 4,4 \\
\hline Inf & 2,3 & 10,8 & 5,7 & 5,9 & 9,3 & 3,7 & 4,2 & 9,5 & 5,7 & 6,5 & 12,8 & 11,7 \\
\hline LVA & 3,7 & 5,1 & 1,1 & 5,5 & 3,0 & 4,3 & 4,2 & 5,4 & 2,0 & 2,8 & 5,9 & 3,1 \\
\hline Soma & $\mathbf{3 7 , 8}$ & $\mathbf{5 2 , 2}$ & $\mathbf{4 5 , 1}$ & $\mathbf{4 9 , 6}$ & $\mathbf{4 7 , 6}$ & $\mathbf{4 3 , 9}$ & $\mathbf{4 7 , 9}$ & $\mathbf{5 2 , 6}$ & $\mathbf{5 1 , 9}$ & $\mathbf{4 9 , 5}$ & $\mathbf{4 7 , 7}$ & $\mathbf{5 1 , 4}$ \\
\hline Org-A & 18,0 & 9,3 & 5,7 & 12,9 & 15,2 & 17,3 & 8,3 & 7,0 & 7,2 & 11,4 & 8,7 & 13,9 \\
\hline Exp & 3,9 & 4,8 & 5,1 & 2,7 & 2,6 & 6,3 & 4,6 & 5,1 & 7,6 & 4,0 & 6,1 & 4,2 \\
\hline Jul & 8,6 & 11,4 & 12 & 8,2 & 7,4 & 7,6 & 8,1 & 9,8 & 7,2 & 8,0 & 9,6 & 8,1 \\
\hline Ava & 2,6 & 1,2 & 1,7 & 4,3 & 3,0 & 3,3 & 2,1 & 2,9 & 3,2 & 2,8 & 4,1 & 1,7 \\
\hline Afe & 2,4 & 0,6 & 0,6 & 1,4 & 0,7 & 4 & 0,2 & 0,3 & 1,5 & 0,3 & 0,4 & 0,8 \\
\hline Soma & $\mathbf{3 5 , 5}$ & $\mathbf{2 7 , 3}$ & $\mathbf{2 5 , 1}$ & $\mathbf{2 9 , 5}$ & $\mathbf{2 8 , 9}$ & $\mathbf{3 8 , 5}$ & $\mathbf{2 3 , 3}$ & $\mathbf{2 5 , 1}$ & $\mathbf{2 6 , 7}$ & $\mathbf{2 6 , 5}$ & $\mathbf{2 8 , 9}$ & $\mathbf{2 8 , 7}$ \\
\hline Cit-C & 5,2 & 3 & 6,3 & 5,7 & 10,0 & 4 & 7,3 & 5,4 & 4,2 & 2,5 & 2,6 & 2,5 \\
\hline Org-I & 6,0 & 6,4 & 3,5 & 6,5 & 2,3 & 1 & 8,6 & 2,9 & 5,4 & 5,6 & 2,0 & 4,2 \\
\hline Res-C & 5,5 & 3,3 & 4,6 & 2,3 & 4,5 & 4 & 5,0 & 6,7 & 3,4 & 3,7 & 1,2 & 4,4 \\
\hline C-Res-c & 9,9 & 7,8 & 15,4 & 6,4 & 6,7 & 8,6 & 7,9 & 7,3 & 8,4 & 12,3 & 17,6 & 8,9 \\
\hline Soma & $\mathbf{2 6 , 6}$ & $\mathbf{2 0 , 5}$ & $\mathbf{2 9 , 8}$ & $\mathbf{2 0 , 9}$ & $\mathbf{2 3 , 5}$ & $\mathbf{1 7 , 6}$ & $\mathbf{2 8 , 8}$ & $\mathbf{2 2 , 3}$ & $\mathbf{2 1 , 4}$ & $\mathbf{2 4 , 1}$ & $\mathbf{2 3 , 4}$ & $\mathbf{2 0}$ \\
\hline
\end{tabular}

Int = interrogação; Res= resposta; C-Res= complemento de resposta; Inf= informação; LVA= leitura em voz alta; Org-A= organização de ação; $E x p=$ experencial; Jul= julgamento; Ava= avaliação; $A f e=$ afetiva; $\mathrm{Cit}-\mathrm{C}=$ citação crítica; Org-I organização de ideia; $\mathrm{Res}-\mathrm{C}=$ resposta crítica e C-Res-C= complemento de resposta crítica.

Para as funções de fala que compõem o primeiro bloco (interrogação, resposta, complemento de resposta, informação e leitura em voz alta), encontramos somatória com valores entre $37,8 \%$ e $52,2 \%$ para os dois grupos cooperativos e encontramos somatórias com valores entre $47,7 \%$ e $52,6 \%$ para os dois grupos colaborativos. Observa-se que os grupos colaborativos, em média, apresentaram somatórias superiores às apresentadas pelos grupos cooperativos. De fato, das quatro maiores porcentagens de ocorrência no que diz respeito às funções do primeiro bloco, três foram localizadas nas atividades colaborativas (51,4\%; $51,9 \%$ e $52,6 \%$ ), enquanto o maior valor encontrado para os grupos cooperativos foi de $52,2 \%$. Apesar das diferenças encontradas, os valores, de uma forma geral, foram significativos para os quatro grupos, o que indica que os alunos se mantiveram dedicados à resolução das atividades nos grupos cooperativos e colaborativos. 
Dessa forma, o resultado mostra que as diferentes estruturas não afetaram o comprometimento dos alunos frente à atividade. Algumas peculiaridades, no entanto, distinguem as interações estabelecidas em cada uma das estratégias.

Conforme ilustra o Quadro 33 , os grupos cooperativos e os grupos colaborativos fizeram uso similar das funções de fala dos tipos interrogação, resposta direta e leitura em voz alta. Para as funções de interrogação, encontramos valores entre $17,1 \%$ e $22,3 \%$ para os grupos cooperativos e valores entre $15,5 \%$ e $26,4 \%$ para os grupos colaborativos. Para as funções de resposta direta encontramos valores entre $8,9 \%$ e $14,3 \%$ para os grupos cooperativos e valores entre $7,4 \%$ e $13,1 \%$ para os grupos colaborativos. Já para a função de fala leitura em voz alta, encontramos valores entre 3,0\% e 5,5\% para cinco das seis atividades dos grupos cooperativos, sendo que apenas a atividade do grupo de especialistas apresentou um valor relativamente menor do que as demais $(1,1 \%)$, e valores entre $2,0 \%$ e $5,9 \%$ para os grupos colaborativos. Os valores citados revelam que ambas as estratégias geraram atividades com caráter objetivo, nas quais os alunos apresentaram uma postura de busca à resolução da atividade e usaram as referidas funções para conduzir suas ações, como se observa a seguir.

O Quadro 34 apresenta trechos do mapa analítico da primeira atividade cooperativa do Grupo 1 e da primeira atividade colaborativa do Grupo 3. Nele são apresentados os fragmentos que evidenciam a forma como as funções de fala interrogação, resposta e leitura em voz alta são utilizadas nas duas estratégias.

Quadro 34 - Trechos do mapa analítico das interações ocorridas na primeira atividade cooperativa do Grupo 1 (Fragmento 55) e na primeira atividade colaborativa do Grupo 3 (Fragmento 56).

(continua)

\begin{tabular}{|c|c|l|c|c|}
\hline $\mathbf{N}^{\circ}$ & $\begin{array}{c}\text { Função de } \\
\text { fala }\end{array}$ & \multicolumn{1}{|c|}{ Fragmento 55 } & Agente \\
\hline 187 & Int & Não é? & PCR & A5 \\
\hline 188 & Res & É que ele colocou aqui para ver como vamos escrever. & PCR & A1 \\
\hline 189 & Org-I & $\begin{array}{l}\text { As reações não param, apesar de a gente, olhando, } \\
\text { parecer que elas pararam, que a reação parou. }\end{array}$ & PCE & A1 \\
\hline 190 & Int & Hum? & PCR & A5 \\
\hline 191 & Int & Entendeu? & PCR & A1 \\
\hline 192 & LVA/Res & $\begin{array}{l}\text { Ele colocou assim: apesar de visualmente parecer que a } \\
\text { reação para. }\end{array}$ & PCR & A1 \\
\hline
\end{tabular}


Quadro 34 - Trechos do mapa analítico das interações ocorridas na primeira atividade cooperativa do Grupo 1 (Fragmento 55) e na primeira atividade colaborativa do Grupo 3 (Fragmento 56).

\begin{tabular}{|c|c|l|c|c|}
\hline $\mathbf{N}^{\circ}$ & $\begin{array}{c}\text { Função de } \\
\text { fala }\end{array}$ & \multicolumn{1}{|c|}{ Fragmento 56 } & & Agente \\
\hline 254 & LVA/C-Res & Bom, o equilíbrio químico da substância água pode ajudar. & PCR & A1 \\
\hline 255 & Org-A & Abre aí porque não dá para ler tudo. & PCR & A1 \\
\hline 256 & LVA/Int & $\begin{array}{l}\text { O equilíbrio químico da substância água pode definir ácidos } \\
\text { base e pH? Se sim, indique como. }\end{array}$ & PCR & A3 \\
\hline 257 & Res & Não. & PCR & A2 \\
\hline 258 & Int & A cinco você manja bastante, não é? & PCR & A2 \\
\hline 259 & Int & O quê? & PCR & A3 \\
\hline 260 & Res & A cinco. & PCR & A2 \\
\hline
\end{tabular}

Os fragmentos 55 e 56 do Quadro 34 ilustram como os grupos cooperativos e colaborativos usam as referidas funções de forma semelhante para conduzir suas atividades. No fragmento 55 o aluno A5 faz uso da função de fala de interrogação, que em seguida é respondida de forma direta pelo aluno A1. Na parte final do trecho, o aluno A1 faz uso da função de fala interrogação e ele mesmo finaliza o trecho fazendo uma leitura em voz alta, que tem como objetivo responder à sua indagação. Ressaltamos a forma como o Aluno A1 busca, com sua pergunta, verificar se o aluno A5 entendeu o que foi exposto e sua preocupação em ajudá-lo.

No fragmento 56, de forma similar, os alunos A1, A2 e A3 conduzem a atividade usando as funções referidas, começando com o aluno $A 1$, que faz uso da função de fala leitura em voz alta, que tem como objetivo complementar de forma direta uma pergunta anterior. Essa inferência faz com que o aluno A3 faça uso do mesmo tipo de função leitura em voz alta, com objetivo de interrogar seus pares. Em seguida, o aluno A2 responde de forma direta, o que leva a outras inferências. Nos dois fragmentos os alunos direcionam a resolução da atividade com o uso das três funções em questão, fato que justifica os valores semelhantes encontrados para as duas estratégias.

Com relação às funções de fala informação e complemento de resposta direta, percebemos que em ambas as estratégias os alunos usaram as referidas funções para auxiliar na realização das atividades. Entretanto, para essas funções encontramos valores diferentes em relação às duas estratégias.

Para a função de fala do tipo complemento de resposta direta, com exceção do valor $9,3 \%$, que se repetiu na primeira atividade cooperativa do Grupo 2 e na primeira atividade do Grupo 3, relativamente maior que as demais para as duas 
estratégias, encontramos valores entre $1,0 \%$ e 3,7\% nos grupos cooperativos, enquanto nos grupos colaborativos encontramos valores entre $4,1 \%$ e $6,1 \%$. Os valores superiores encontrados para as atividades colaborativas indicam que as respostas diretas e seus complementos se mostram suficientes para direcionar os grupos colaborativos no decorrer das atividades, como ilustram os fragmentos 42 e 43 do Quadro 26. Nele os alunos dos Grupos 3 e 4 fazem uso das diferentes funções do primeiro bloco para direcionar sua atividade e fecham suas respostas com um ou mais complementos de respostas diretas, que no caso se mostram suficientes para conduzir a atividade colaborativa, fato que não acontece nos grupos cooperativos de forma tão pronunciada.

Para a função de fala de informação encontramos para ambas as estratégias valores bem variados. Para os grupos cooperativos encontramos valores entre 2,3\% e $10,8 \%$ e para os grupos colaborativos encontramos valores entre $4,2 \%$ e $12,8 \%$. Apesar de a variação ter aparecido nas duas estratégias, chama a atenção o fato de os grupos cooperativos não apresentarem nenhuma tendência (enquanto os valores aumentam entre a primeira $(2,3 \%)$ e a terceira atividade $(9,3 \%)$ no Grupo 1, no Grupo 2 há uma diminuição de 10,8\% na primeira atividade para 3,7\% na terceira atividade). Já nos grupos colaborativos percebe-se que ocorre um aumento da primeira para a terceira de $4,2 \%$ para $5,7 \%$ no Grupo 3 , e de $6,5 \%$ para $12,8 \%$ no Grupo 4.

Conforme ilustra o Quadro 33, para as funções de fala que compõem o segundo bloco (organização de ação, experiencial, julgamento, avaliação e afetiva), nos grupos cooperativos a somatória apresentou valores entre $25,1 \%$ e $38,5 \%$, enquanto para os grupos colaborativos a somatória apresentou valores entre $23,3 \%$ e $28,9 \%$. Os valores encontrados para os dois grupos cooperativos apresentaram uma variação considerável no decorrer das atividades, não sendo identificada nenhuma tendência. Diferentemente, para os grupos colaborativos percebemos pouca variação, com valores entre $23,3 \%$ e 26,7\% para o Grupo 3 e valores entre $26,5 \%$ e $28,7 \%$ para o Grupo 4 . Somado a isso, apontamos o aumento gradativo no uso dessas funções da primeira para terceira atividade.

Os valores encontrados para a função de fala do tipo organização de ação foram relativamente superiores nos grupos cooperativos frente aos encontrados para os grupos colaborativos. De fato, as três maiores porcentagens de ocorrência no que 
diz respeito à função organização de ação foram localizadas nos grupos cooperativos $(15,2 \%, 17,3 \%$ e 18,0\%), enquanto o maior valor encontrado para os grupos colaborativos foi de 13,9\%. Relacionamos as diferenças encontradas com a diferença na estrutura de cada estratégia, tendo em vista que o uso dessa função permite que os alunos organizem e direcionem a atividade, de modo que o uso significativo dessa função se revela mais pronunciado em atividades mais estruturadas, como ilustra o fragmento 14 do Quadro 11. Nela os três alunos A1, A2 e A4 do Grupo 1 fazem uso da função de organização de ação para chamar a atenção e orientar o grupo na direção da postura correta para a boa prática da atividade. Há de se apontar, ainda, que os valores encontrados para os grupos colaborativos apresentam uma diferença com relação à referida função, com valores entre $7,0 \%$ e $8,3 \%$ para o Grupo 3, e valores entre 8,7\% e 13,9\% para o Grupo 4 . Relacionamos o uso superior feito pelo Grupo 4 a peculiaridades dos alunos que fizeram parte do grupo, tendo em vista que, em comparação ao Grupo 3, todos os demais fatores eram idênticos.

Para a função de fala do tipo experiencial, encontramos valores entre $2,6 \%$ e $6,3 \%$ para os grupos cooperativos e valores entre $4,0 \%$ e $7,6 \%$ para os grupos colaborativos. A pequena diferença encontrada para a referida função sugere que os alunos dos grupos colaborativos encontraram dentro das suas atividades mais oportunidades de compartilhar suas experiências com seus pares do que os alunos do grupo cooperativo. Relacionamos essa diferença, mesmo que pequena, à estrutura dos grupos colaborativos, que é menos estruturada, o que oferece ao aluno maior liberdade dentro do grupo, e também à formação dos grupos, lembrando que apenas os grupos cooperativos foram formados de forma heterogênea e, como consequência, os alunos não se agruparam por empatia, como aconteceu nos grupos colaborativos.

Para as funções de fala do tipo, julgamento, avaliação e afetiva encontramos valores semelhantes para os grupos cooperativos e colaborativos. Para a função de fala afetiva foram encontrados resultados poucos expressivos para as duas estratégias, na sua maioria inferiores a 1,5\%, com apenas dois valores destoantes dos demais, sendo eles 2,4\% para a primeira atividade cooperativa do Grupo 1 e $4,0 \%$ para terceira atividade cooperativa do Grupo 2. Para a função de fala do tipo julgamento, encontramos valores entre $7,4 \%$ e $12 \%$ para os grupos cooperativos e valores entre $7,2 \%$ e $9,8 \%$ para os grupos colaborativos. Para a função de fala do 
tipo avaliação, encontramos valores entre 1,2\% e 4,3\% para os grupos cooperativos e valores entre $1,7 \%$ e $4,1 \%$ para os grupos colaborativos. O uso similar encontrado para as três funções nas duas estratégias indica que, mesmo frente a diferenças estruturais, os alunos que participaram de ambas sentiram a necessidade e tiveram a liberdade de julgar e avaliar seus pares, tanto nos grupos cooperativos quanto nos grupos colaborativos.

Como ilustra o fragmento 16 do Quadro 13, os alunos A1, A2 e A3 do Grupo 2 fazem uso das funções de avaliação, organização de ação e afetiva. No fragmento 47 do Quadro 28 os alunos A1, A2 e A3 do Grupo 3 fazem uso das funções julgamento, organização de ação e experiencial. Estes fragmentos, dentre outros, sugerem um ambiente social favorável e seguro, que se repetiu nos quatro grupos independentemente da estratégia.

Conforme ilustra o Quadro 33, para as funções de fala que compõem o terceiro bloco (organização de ideia, citação crítica, resposta crítica e complemento de resposta crítica) encontramos valores similares para as duas estratégias. A somatória dessas funções para os grupos cooperativos apresentou valores entre $17,6 \%$ e $29,8 \%$. Já para os grupos colaborativos, encontramos somatória entre $20 \%$ e $28,8 \%$. Os valores sugerem que os alunos das duas estratégias participaram de atividades que exigiram respostas críticas e reflexivas.

Os valores encontrados para a função citação crítica para os grupos cooperativos foram relativamente maiores do que os encontrados para os grupos colaborativos. De fato, dentre as quatro maiores porcentagens de ocorrência no que diz respeito à função de citação crítica, três foram localizadas nos grupos cooperativos $(5,7 \%, 6,3 \%$ e $10 \%)$, enquanto o maior valor encontrado para os grupos colaborativos foi de $7,3 \%$. Os valores também denotaram tendências diferentes nas duas estratégias. Para os dois grupos cooperativos, observou-se um aumento no uso da referida função da primeira para a terceira atividade, enquanto para as atividades colaborativas do Grupo 3 encontramos uma redução e para o Grupo 4 os valores não mudaram. Os valores mais elevados na terceira atividade dos grupos cooperativos, provavelmente, relacionam-se à estrutura da atividade, que exige a formação dos grupos de especialistas, fazendo com que os alunos voltem para seus grupos de base com um conhecimento aprofundado de um 
determinado assunto, o que gera postura mais crítica frente ao tema trabalhado, como se observa a seguir.

O Quadro 35 apresenta trechos do mapa analítico da terceira atividade cooperativa dos Grupos 1 e 2. Nele são apresentados os fragmentos 57 e 58, que evidenciam o uso da função citação crítica.

Quadro 35 - Trechos do mapa analítico das interações ocorridas na terceira atividade cooperativa do Grupo 1 (Fragmento 57) e na terceira atividade cooperativa do Grupo 2 (Fragmento 58).

\begin{tabular}{|c|c|c|c|}
\hline $\mathbf{N}^{\circ}$ & $\begin{array}{c}\text { Função } \\
\text { de fala }\end{array}$ & Fragmento 57 & Agente \\
\hline 31 & C-Res-C & Ela pode ser reversível em qualquer momento. & A3 \\
\hline 32 & Cit-C & $\begin{array}{l}\text { Não. Reversibilidade nesse caso não é em relação ao processo } \\
\text { reversível. Reversibilidade, nesse caso, é só em relação à reação } \\
\text { direta ou inversa. }\end{array}$ & A1 \\
\hline 33 & C-Res-C & $\begin{array}{l}\text { Por exemplo, o equilíbrio tem a composição do sistema e a } \\
\text { composição do sistema tem uma determinada variação de energia } \\
\text { livre. E ela vai tendendo até a variação de energia ser igual a zero. }\end{array}$ & $\mathrm{A} 1$ \\
\hline $\mathbf{N}^{\circ}$ & $\begin{array}{c}\text { Função } \\
\text { de fala }\end{array}$ & Fragmento 58 & Agente \\
\hline 102 & C-Res-C & $\mathrm{O}$ pH continua constante. & A4 \\
\hline 103 & Cit-C & $\begin{array}{l}\text { Sim, mas se o pH do sangue mudar, o ferro, se não me engano, que } \\
\text { está no sangue. }\end{array}$ & A1 \\
\hline 104 & C-Res-C & Pode desequilibrar várias coisas no corpo. & A4 \\
\hline 105 & Org-A & Mas calma, não é isso que quero explicar. & A1 \\
\hline
\end{tabular}

No fragmento 57, após o aluno A3 fazer um complemento de resposta crítica, o aluno A1 faz uma citação crítica e, em seguida, faz um novo complemento crítico para a resposta. Observa-se que a citação crítica apresenta um embasamento teórico substancial sobre a temática Equilíbrio Químico, que era um dos temas estudados pelo grupo de especialistas. Denotamos, ainda, que os fragmentos foram extraídos de interações discursivas ocorridas no início da terceira atividade (retorno aos grupos de base), mostrando que o aluno trouxe consigo conhecimentos específicos para executá-la. De forma semelhante, no fragmento 58 o aluno A1 faz uso da função de citação crítica, mas neste caso o embasamento teórico é relativo ao tema Ácido e Base, outro tema específico estudado nos grupos de especialistas, o que corrobora os resultados e apontamentos realizados.

Para a função de fala do tipo organização de ideia encontramos variações nos valores das duas estratégias, com valores entre $1 \%$ e $6,5 \%$ para os grupos cooperativos e valores entre $2,0 \%$ e $8,6 \%$ para os grupos colaborativos. Apesar da variação em ambas as estratégias, destacamos que não foi encontrada nenhuma 
tendência nos valores apresentados para os grupos colaborativos. Diferentemente, para os grupos cooperativos, percebe-se que, da primeira para a terceira atividade, ocorre uma redução no uso da referida função, fato que relacionamos com a estrutura da atividade e com a participação dos alunos nos grupos cooperativos de especialistas. Estes, ao voltarem para os grupos de base, fazem uso da função de fala citação crítica em detrimento da função de organização de ideia. Como ilustra o Quadro 35 com os fragmentos 57 e 58.

Com relação às funções de fala resposta crítica e complemento de resposta crítica, percebemos que os alunos fizeram uso similar dessas funções nas duas estratégias, com valores entre 2,3\% e 5,5\% para as atividades dos grupos cooperativos no que se refere à função de resposta crítica, e com valores entre 1,2\% e 6,7\% para as atividades dos grupos colaborativos para a mesma função. Já para a função de fala complemento de resposta crítica foram encontrados valores entre $6,4 \%$ e $15,4 \%$ para os grupos cooperativos e valores entre $7,3 \%$ e $17,6 \%$ para os grupos colaborativos. Os resultados sugerem que o uso das duas funções não foi afetado substancialmente pela estrutura específica das estratégias.

\subsubsection{Análise das interações discursivas na perspectiva da segunda dimensão: processamento cognitivo}

A análise das interações discursivas foi realizada por meio dos três tipos de processamentos cognitivos, rotineiro, off-task e exploratório, nos mesmos moldes empregados anteriormente.

Na Figura 19 apresentamos a frequência expressa em porcentagem em que cada processamento cognitivo foi utilizado nos grupos cooperativos e nos grupos colaborativos nas três atividades da Turma C. 
Figura 19 - Porcentagem de uso dos processamentos cognitivos durante a resolução das três atividades cooperativas nos Grupo 1 e 2 da Turma $C$ (a) e das três atividades colaborativas nos Grupos 3 e 4 da Turma C (b).

(a)
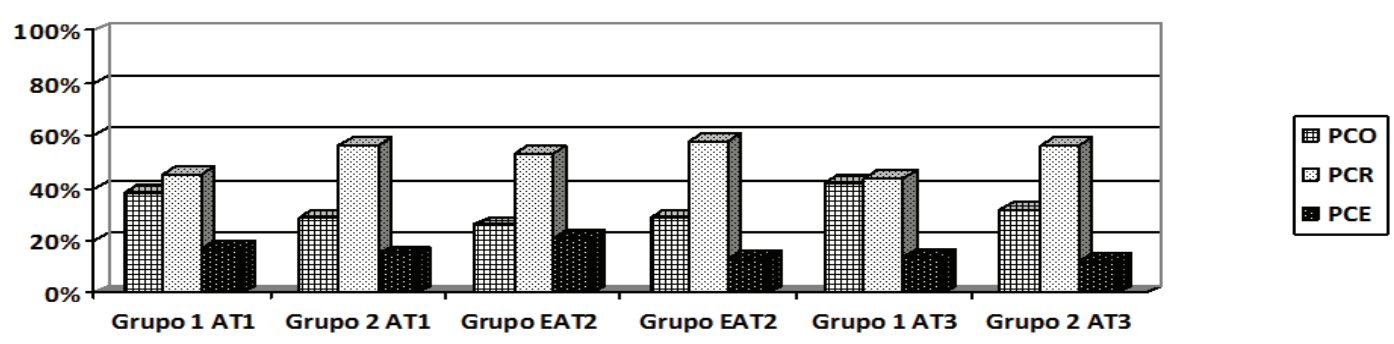

(b)
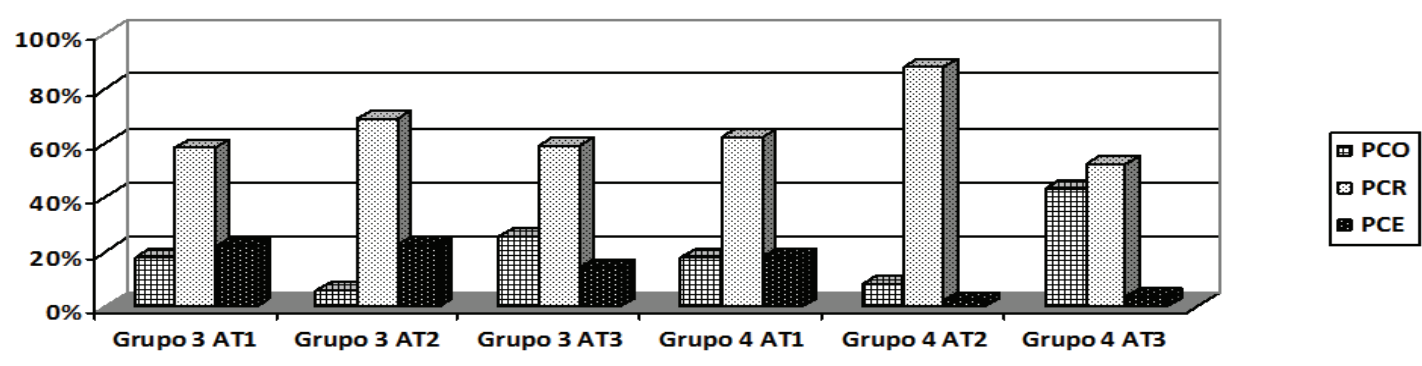

A análise da Figura 19 indica a seguinte tendência para a ocorrência dos processamentos cognitivos nos grupos: o uso do processamento cognitivo rotineiro foi superior em todos os grupos, nas três atividades nas duas estratégias, sendo que o menor valor apresentado foi de $44 \%$, na terceira atividade cooperativa do Grupo 1 , e o valor máximo foi de $88 \%$, na segunda atividade colaborativa do Grupo 4; o processamento cognitivo off-task foi o segundo mais recorrente em nove das doze atividades analisadas, sendo que o menor valor apresentado foi de $6 \%$, na segunda atividade colaborativa do Grupo 3, e o valor máximo apresentado foi de $43 \%$, na terceira atividade colaborativa do Grupo 4; o processamento cognitivo exploratório foi o menos recorrente em nove das doze atividades analisadas, sendo que o menor valor apresentado foi de $3 \%$, na segunda atividade colaborativa do Grupo 4, e o valor máximo apresentado foi de $24 \%$, na segunda atividade colaborativa do Grupo 3. Ressaltamos, ainda, os resultados encontrados na primeira atividade colaborativa do Grupo 4, no qual encontramos valor de $19 \%$ tanto para o processamento cognitivo off-task, quanto para o processamento cognitivo exploratório.

No que diz respeito ao processamento cognitivo rotineiro, os valores encontrados para os grupos colaborativos foram relativamente maiores do que os encontrados para os grupos cooperativos. De fato, as três maiores porcentagens de 
ocorrência no que diz respeito ao processamento cognitivo rotineiro foram aí encontrados $(62 \%, 69 \%$ e $88 \%)$, enquanto o maior valor encontrado para os grupos cooperativos foi de $58 \%$. Os valores elevados encontrados para os grupos colaborativos denotam que o trabalho aí realizado apresentou um caráter consideravelmente rotineiro, o que reforça os valores encontrados para os grupos colaborativos no que diz respeito ao uso superior das funções de fala do primeiro bloco. Assim, é possível especular que as atividades colaborativas apresentaram características mais objetivas do que as realizadas nos grupos cooperativos.

Os valores encontrados para o processamento cognitivo exploratório revelaram comportamentos bem definidos para as duas estratégias, tendo os grupos cooperativos apresentado uso significativo, com pequena redução da primeira para terceira atividade, com valores indo de 17\% (Grupo1 AT1) para 14\% (Grupo1 AT3) para o Grupo 1, e com valores indo de 15\% para 12\% para o Grupo 2. De forma semelhante nos grupos colaborativos encontramos uma redução da primeira para terceira atividade, com valores indo de $23 \%$ para $15 \%$ para o Grupo 3, com valores indo de $19 \%$ para $4 \%$ para o Grupo 4.

Ainda com relação ao processamento cognitivo exploratório, ressaltamos a ampla faixa de valores encontrados para os grupos colaborativos. De fato, ocorre variação que vai de $3 \%$ a $24 \%$ para a mesma estratégia. O que reafirma o caráter irregular das atividades colaborativas na perspectiva dos processamentos cognitivos. Assim, embora tenhamos observado uso significativo das funções de caráter crítico (terceiro bloco) para ambos os grupos colaborativos, este uso não implica, necessariamente, no desencadeamento de processamento cognitivo exploratório.

O Quadro 36 apresenta trecho do mapa analítico da terceira atividade colaborativa do Grupo 4, e da terceira atividade cooperativa do Grupo 2. Nele são apresentados fragmentos que evidenciam a relação entre as funções de fala, principalmente do terceiro bloco, e o processamento cognitivo. 
Quadro 36 - Trechos do mapa analítico das interações ocorridas na terceira atividade colaborativa do Grupo 4 (Fragmento 59) e da terceira atividade cooperativa do Grupo 2 (Fragmento 60).

\begin{tabular}{|c|c|l|c|c|}
\hline $\mathbf{N}^{\circ}$ & $\begin{array}{c}\text { Função de } \\
\text { fala }\end{array}$ & \multicolumn{1}{|c|}{ Fragmento 59 } & Agente \\
\hline 289 & $\mathbf{C}-$ Res-C & Então olha, como que vai formar isso aqui $\left(\mathrm{H}_{3} \mathrm{O}+2 \mathrm{NO}_{2}+\mathrm{K}^{+}\right)$ & PCE & $\mathrm{A} 3$ \\
\hline 290 & Res-C & $\begin{array}{l}\text { Eu tenho a impressão que essa primeira é uma solução } \\
\text { tampão. }\end{array}$ & PCR & $\mathrm{A} 2$ \\
\hline 291 & Int & $\begin{array}{l}\mathrm{NO}_{2} \text {, olha gente, é isso aqui o equilíbrio, vocês concordam } \\
\text { comigo? }\end{array}$ & PCE & A3 \\
\hline 292 & Res-C & Vai dar $\mathrm{NO}_{2}$. & PCR & A4 \\
\hline $\mathbf{N}^{\circ}$ & $\begin{array}{c}\text { Função de } \\
\text { fala }\end{array}$ & \multicolumn{1}{c}{ Fragmento 60 } & Agente \\
\hline 99 & Int & É isso que está pedindo? & PCE & A1 \\
\hline 100 & $\begin{array}{c}\text { C-Res-C } \\
\text { Porque qualquer reação que acontece no nosso corpo, não } \\
\text { vai desequilibrá-lo, entende, equilíbrio químico. }\end{array}$ & PCE & A4 \\
\hline 102 & C-Res-C & O pH continua constante. & PCE & A1 \\
\hline 103 & Cit-C & $\begin{array}{l}\text { Sim, mas se o pH do sangue mudar, o ferro, se não me } \\
\text { engano, que está no sangue. }\end{array}$ & PCE & A1 \\
\hline
\end{tabular}

No fragmento 59 o trecho inicia com o aluno A3 complementando uma resposta de forma crítica e com caráter exploratório, em seguida o aluno A2 sugere uma nova resposta crítica, mas não dá continuidade ao caráter exploratório. Novamente, o aluno A3 faz uma interrogação com caráter exploratório, e por fim, o fragmento é finalizado com o aluno A4 respondendo de forma crítica, mas não dando continuidade ao caráter exploratório. Chama atenção o fato de que uma resposta com embasamento teórico garante o caráter crítico, mas não o caráter exploratório da atividade. Diferentemente, o fragmento 60 inicia-se com o aluno A1 realizando uma interrogação que, dentro do contexto, apresenta um caráter exploratório já que instiga o aluno A4 a fazer um complemento crítico direcionado para a interrogação realizada. Em seguida, o aluno A1 complementa também de forma crítica e finaliza com uma citação crítica que não tem como objetivo fechar a discussão e sim fornecer mais elementos para análise. Fato que justifica os valores encontrados para o processamento cognitivo exploratório para as duas estratégias

Por fim, ao analisarmos comparativamente a frequência do processamento cognitivo off-task, verificamos que os grupos apresentaram tendência destoantes quando se verificam as atividades de forma sequencial, da primeira para terceira. Assim, para os grupos colaborativos valores vão de $18 \%$ na primeira atividade para $26 \%$ para o Grupo 3, e de $18 \%$ na primeira atividade para $43 \%$ na terceira para o Grupo 4. O uso elevado desse processamento na terceira atividade de forma similar para os dois grupos justifica-se pelo seu caráter finalizador, o que leva os alunos a 
apresentar um comportamento mais descontraído na última atividade do que nas demais. Já para os grupos cooperativos os valores apresentam uma pequena variação nos dois grupos, de $38 \%$ para $42 \%$ no Grupo 1, e de $29 \%$ para $32 \%$ no Grupo 2. Relacionamos a consistência nos valores encontrados para os grupos cooperativos com a estrutura das atividades que permite, mesmo durante a sua finalização, o estabelecimento de um ambiente descontraído, mas sem que se observem distrações que comprometam a execução da atividade.

\subsubsection{Análise das interações discursivas na perspectiva da terceira dimensão: processamento social}

A análise dos quatro tipos de processamentos sociais, colaborativo, tutorial, individualista e competitivo, foi realizada, nos mesmos moldes empregados anteriormente. Com base nas informações contidas nos mapas analíticos, identificamos as interações dominantes ocorridas no decorrer da resolução das três atividades cooperativas do Grupo 1 e do Grupo 2 e das atividades colaborativas do Grupo 3 e do Grupo 4 da Turma C. A Figura 20 ilustra os tipos de interações sociais considerados, assim como a porcentagem com que cada um foi utilizado.

Figura 20 - Porcentagem de uso dos processamentos sociais durante a resolução das três atividades dos Grupos 1 e 2 cooperativos (a) e das três atividades dos Grupos 3 e 4 colaborativos (b), AT1= primeira atividade e AT3= terceira atividade.

(a)
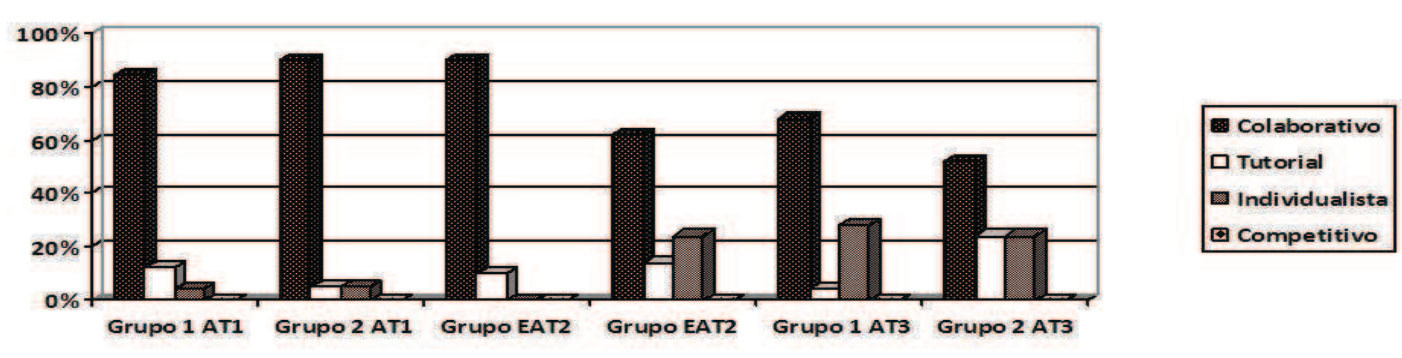

(b)
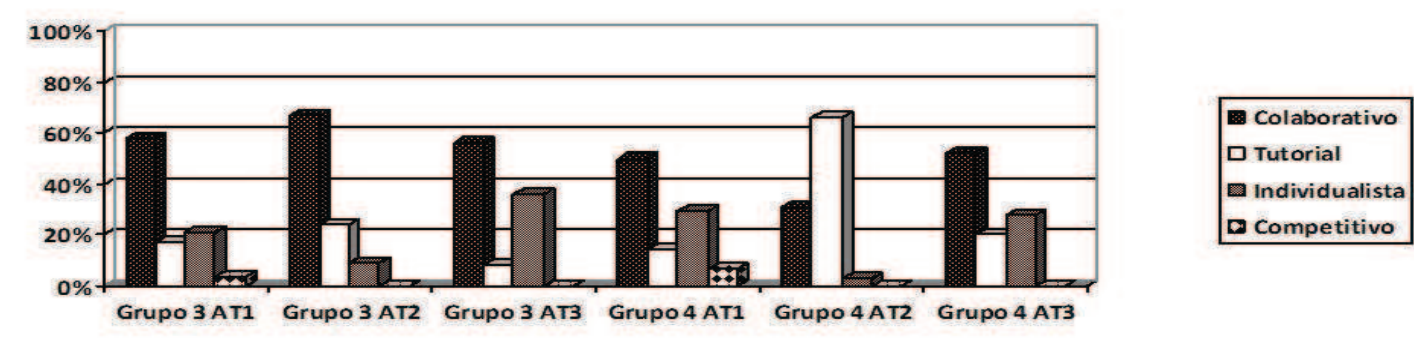
Em praticamente todas as atividades cooperativas e colaborativas 0 processamento social colaborativo foi predominante, com valores entre $52 \%$ e $90 \%$ para as atividades cooperativas, e valores entre $31 \%$ e $67 \%$ para as atividades colaborativas. O valor de 31\%, encontrado para a segunda atividade do Grupo 4, é o único que não se alinha com os demais, com predomínio do processamento tipo tutorial. Os valores revelam que, de uma forma geral, as duas estratégias tiveram a colaboração como característica social principal.

De forma semelhante ao verificado na análise da segunda dimensão para os grupos colaborativos, dentro das três atividades o processamento social colaborativo apresentou valores variáveis, não permitindo a definição de uma tendência. Já para os grupos cooperativos percebe-se uma redução nos valores encontrados na passagem da primeira para terceira atividade nos dois grupos, com valores indo de $84 \%$ para $68 \%$ no Grupo 1, e valores indo de $90 \%$ a $52 \%$ no Grupo 2. Tanto os resultados encontrados para os grupos cooperativos quanto para os grupos colaborativos podem ser relacionados com a estrutura especifica de cada estratégia. Nos grupos colaborativos a variação reforça a ideia sobre a influência da falta de estrutura dos grupos que traz para a atividade uma dependência muito grande das características dos membros dos grupos. Soma-se a isso a presença do líder-par que leva os alunos a migrarem de um comportamento colaborativo para um tutorial.

O Quadro 37 apresenta trechos do mapa analítico da segunda atividade do Grupo 3 da Turma C, que evidenciam como a presença do líder-par influencia no modo de trabalho dos grupos.

Quadro 37 - Trechos do mapa analítico das interações ocorridas na segunda atividade do Grupo 3 da Turma C (Fragmento 61).

\begin{tabular}{|c|c|l|c|}
\hline $\mathbf{N}^{\circ}$ & $\begin{array}{c}\text { Função } \\
\text { de fala }\end{array}$ & \multicolumn{1}{|c|}{ Fragmento 61 } & Agente \\
\hline 43 & Int & $\begin{array}{l}\text { Cadê as outras questões que eu queria perguntar para ele (o líder- } \\
\text { par)? }\end{array}$ & A2 \\
\hline 44 & Res & Acho que ele (o líder-par) vai entregar depois. & A3 \\
\hline 45 & Int & Cadê as nossas questões? & A3 \\
\hline 46 & Inf & Tem que entregar para ele (o líder-par). & A2 \\
\hline
\end{tabular}

O fragmento 61 do Quadro 37 ilustra como os alunos acabam retardando a execução da atividade ou simplesmente esperando que a resposta venha do líder- 
par ao invés de discutir e buscar a resolução da atividade. No fragmento 61 o aluno A2 usa a função de fala interrogação indicando que ele vai esperar as respostas vindas do líder-par. Em seguida, o aluno A3 responde à pergunta, mas não suscita a opção de responder às questões e sim complementa o fragmento com outra interrogação que vai culminar com uma inferência do aluno A2 que cita o líder-par. Estes, dentre outros fragmentos, denotam que, até certo ponto, a existência do líderpar retarda e pode até impedir que os alunos busquem as respostas por eles mesmos. O que transforma um momento que poderia ser colaborativo em um tutorial.

Para os grupos cooperativos a influência da estrutura se relaciona com a passagem pelo grupo de especialistas que traz para a terceira atividade uma nova necessidade, já que os alunos especialistas precisam dividir o conhecimento adquirido, diminuindo assim o processamento colaborativo e aumentando o processamento tutorial. Conforme ilustra o Quadro 35 (fragmentos 57 e 58), os alunos originários dos grupos de especialistas fazem uso do conhecimento adquirido para orientar e direcionar a atividade cooperativa. Cabe lembrar que, diferentemente da atividade colaborativa, o processamento social tutorial na atividade cooperativa parte também dos alunos e não só do monitor.

O segundo processamento social em destaque foi 0 do tipo tutorial apresentando resultados significativos para os quatro grupos nas duas estratégias, com valores entre $8 \%$ e $66 \%$ para os grupos colaborativos, e valores entre $4 \%$ e $14 \%$ para os grupos cooperativos. Assim como para o processamento social colaborativo, encontramos uma grande variação para o processamento tutorial nas duas estratégias, o que reforça os resultados encontrados anteriormente para o processamento colaborativo e aponta para uma relação entre o comportamento do grupo e a estrutura das atividades. Cabe lembrar que estes resultados coadunam com os resultados encontrados nas demais dimensões.

Para o processamento social do tipo individualista destacamos o fato dele ter sido encontrado nas três atividades realizadas pelos dois grupos colaborativos com valores entre $3 \%$ e $33 \%$. Já para os grupos cooperativos esse tipo de processamento social foi verificado em cinco das seis atividades, com valores entre $4 \%$ e $28 \%$. Por fim, ressaltamos os valores encontrados para o processamento social do tipo competitivo, encontrado na primeira atividade dos dois grupos 
colaborativo. Já para os grupos cooperativos o referido processamento social não foi encontrado em nenhuma atividade. Relacionamos esses valores com a formação do grupo apresentada pelas diferentes estratégias, lembrando que os grupos cooperativos são montados de forma heterogênea, com alunos de diferentes características, com o objetivo de equilibrar as ações dentro da atividade. Por outro lado, os grupos colaborativos são livres e formados muitas vezes por empatia, o que leva os alunos a compartilharem momentos de máxima interação - como ilustra o Quadro 28 (fragmento 47), quando os alunos interagem por meio de funções de julgamento, organização de ação e experiencial - e momentos de mínima interação, quando os alunos interagem de forma não colaborativa, como revelam os valores referentes ao processamento social competitivo.

A discussão dos dados apresentados até o momento fornece subsídios para que possamos fazer considerações sobre a nossa terceira questão de pesquisa: de que forma o grau de estrutura da atividade de pequeno grupo pode interferir na dinâmica das interações discursivas em uma mesma disciplina?

Os alunos dos grupos cooperativos jigsaw lidaram com a estrutura bem definida, inerente à própria estratégia, e apesar da complexidade do conteúdo abordado na disciplina, pautaram as suas interações discursivas principalmente no uso das funções de fala do primeiro bloco, embora também tenham feito uso considerável das funções do segundo e do terceiro bloco.

Nessa perspectiva, para as funções do primeiro bloco não percebemos a influência da passagem dos alunos pelos grupos de especialistas, uma vez que os valores praticamente não se alteram da primeira para a terceira atividade. Em contraponto, para o segundo bloco o mesmo não ocorre: o uso das funções de fala organização de ação e avaliação aumenta da primeira para terceira atividade para os dois grupos. Esta variação é esperada, já que na terceira atividade os alunos vindos dos grupos de especialistas deveriam dividir o conhecimento especifico aí adquirido com os colegas do grupo de base, sendo imprescindível que estes últimos fossem capazes de avaliar suas contribuições, o que também justifica o uso considerável da função do tipo julgamento. Na mesma perspectiva, a função de fala organização de ação é acentuada na terceira atividade pois existe a necessidade de organizá-la com o intuito de retomar as ações desencadeadas na primeira atividade.

A influência dos grupos de especialistas é também notada a partir do aumento do uso de uma das funções de fala do terceiro bloco, a citação critica. O que é 
compreensível visto que os alunos voltam para seus grupos de base com um conhecimento aprofundado de um determinado assunto, o que gera postura mais crítica frente ao tema trabalhado. Em contraponto observamos uma redução da primeira para a terceira atividade no uso da função de fala do tipo organização de ideia. Fato que também pode ser relacionado com a passagem pelo grupo de especialistas, visto que na terceira atividade os alunos praticamente fazem uma exposição dos conhecimentos aí adquiridos, não mais existindo tão fortemente a necessidade de organização ou sumarização das ideias apresentadas.

O processamento cognitivo predominante observado foi o rotineiro. No entanto, o processamento cognitivo exploratório foi significativo, sendo sobrepujado com relação ao anterior no máximo em 4,5 vezes. Constatação esta que é perfeitamente coerente com as funções de fala utilizadas na resolução da atividade. De fato, o uso acentuado das funções do terceiro bloco desencadeou processamentos cognitivos do tipo em questão. O que creditamos à passagem dos alunos pelos grupos de especialistas e à formação heterogênea dos grupos de base. Ressaltamos ainda os valores encontrados para o processamento cognitivo off-task, mais recorrente nas atividades finais, frente às iniciais, o que revela que, apesar da estrutura bem definida da estratégia jigsaw, é possível que os alunos trabalhem de forma exploratória e em um ambiente socialmente descontraído.

Para a terceira dimensão encontramos o processamento social colaborativo como dominante, embora com diminuição na sua incidência da primeira para a terceira atividade, enquanto o contrário ocorre com o processamento social individualista, o que se deve ao fato do caráter de colaboração ser menor na terceira atividade, quando os alunos provenientes dos grupos de especialista fazem, principalmente uma exposição das suas ideias, conforme mencionado anteriormente. Já com relação ao processamento social tutorial este é observado em todas as atividades devido a dois fatores vinculados à estrutura da estratégia, a passagem pelos grupos de especialistas e a formação heterogênea dos grupos de base, que possibilita o compartilhamento de ideias entre alunos com perfis acadêmicos diferentes, fazendo com que possam aprender com seus pares. Destacamos ainda a ausência de processamentos sociais do tipo competitivo, o que se constitui em resultado bastante animador. 
Com relação aos alunos dos grupos colaborativos PLTL, embora tenham lidado com atividades de baixo grau de estruturação, empenharam-se em discussões críticas e embasadas e adaptaram-se às características estruturais da estratégia para o alcance dos seus objetivos. Apesar da complexidade do conteúdo trabalhado na disciplina, os resultados revelaram que, assim como os alunos da estratégia jigsaw, estes também fizeram uso preferencial das funções de fala do primeiro bloco e também fizeram uso considerável das funções do segundo e do terceiro bloco. No entanto, o uso da função de fala complemento de resposta direta foi mais frequente nos grupos colaborativos, indicando que as respostas diretas e seus complementos se mostram suficientes para direcionar tais grupos no decorrer das atividades, o que não ocorreu nas atividades cooperativas.

Para as funções do segundo bloco encontramos um uso similar para os grupos colaborativos ao encontrado nos grupos cooperativos, cabendo apenas destacar o uso superior feito nos grupos colaborativos da função de fala do tipo experiencial, o que revela que a atividade não estruturada proporcionou uma maior possibilidade de compartilhamento de experiências pessoais entre os alunos.

Para as funções do terceiro bloco ressaltamos o uso irregular da função citação crítica apresentado pelos grupos colaborativos. A irregularidade no uso dessa função foi uma das diferenças mais marcantes entre as duas estratégias e pode ser relacionada com o caráter menos estruturado da atividade colaborativa, uma vez que a passagem pelo grupo de especialistas na estratégia jigsaw tende a elevar a criticidade dos alunos frente ao conteúdo estudado.

Para a segunda dimensão também foram observados valores irregulares nos grupos colaborativos, dentre eles destacamos os valores encontrados para o processamento cognitivo exploratório, que apresentaram uma grande discrepância dentro do conjunto de atividade realizadas, com valores indo de $3 \%$ a $24 \%$, resultado que se deve, provavelmente, à influência da falta de estrutura da atividade.

Para a terceira dimensão destacamos o processamento social tutorial, que na segunda atividade do Grupo 4 chegou a sobrepujar o processamento social colaborativo, mostrando a influência do líder-par nas atividades dos grupos colaborativos. Cabe ressaltar que, conforme mencionado anteriormente, a participação do líder-par, na maioria das vezes, se mostra positiva, entretanto pode conduzir os alunos a um comportamento de dependência. Além disso, diferentemente dos grupos cooperativos, ocorreu a presença de processamento 
social competitivo, o que também pode estar relacionado com a falta de estruturação bem definida no trabalho dos grupos. 


\section{CONSIDERAÇÕES FINAIS}

Nesta tese investigamos questões relacionadas à dinâmica das interações discursivas estabelecidas em pequenos grupos cooperativos e colaborativos no Ensino Superior de Química. Uma revisão bibliográfica no contexto nacional e internacional sobre a temática em pauta mostrou acentuado crescimento no número de trabalhos relacionados às estratégias jigsaw e PLTL nas últimas três décadas. Em contraponto, especificamente no Brasil, a produção sobre o assunto ainda é incipiente e concentrada na região Sudeste. Este cenário, portanto, sugere a relevância de pesquisas como a que aqui apresentamos, na qual tratamos, entre outros aspectos, da influência do tipo de conteúdo e da estrutura dos grupos na forma como as interações discursivas são estabelecidas em disciplinas oferecidas em um Curso de Bacharelado em Química.

Com relação aos resultados encontrados, referentes às diferentes disciplinas nas quais se aplicou a estratégia cooperativa jigsaw, estes indicam que as interações discursivas nos grupos estão notadamente atreladas às características mais marcantes dos conteúdos nelas ministrados. Assim, para disciplinas que exigem dos alunos uma capacidade de abstração elevada para a compreensão dos conteúdos, ocorre o uso acentuado de funções de fala capazes de refletir as interações entre os alunos baseadas em exercício crítico-reflexivo com demanda cognitiva complexa (funções do terceiro bloco). Já para as disciplinas em que a compreensão dos conteúdos não apresenta tal demanda, verifica-se o uso recorrente das demais funções de fala (especialmente as funções do primeiro bloco), capazes de refletir as interações entre os alunos na busca direta e objetiva pela resolução da atividade.

No que se refere à segunda e à terceira dimensão de análise, percebemos que a aplicação da estratégia cooperativa jigsaw gerou processamentos cognitivos condizentes com as funções de fala identificadas e conduziu os alunos à realização de atividades com caráter colaborativo e de tutorial. É ainda importante destacar a pouca incidência de processamento social individualista e a ausência de processamento do tipo competitivo. Resultado este que está em harmonia com os princípios da aprendizagem cooperativa, que busca reduzir a aprendizagem baseada na competição, fortalecendo o comportamento colaborativo entre os alunos. 
Com relação aos resultados encontrados, referentes às diferentes disciplinas nas quais se aplicou a estratégia colaborativa PLTL, estes indicam que as interações discursivas nos grupos não estão atreladas às características mais marcantes dos conteúdos nelas ministrados, diferentemente do observado para a estratégia cooperativa jigsaw. De fato, o uso das funções de fala é semelhante em ambas e a conexão entre as funções de fala e os processamentos cognitivos é tênue.

No que se refere à terceira dimensão de análise, percebemos que a aplicação da estratégia colaborativa PLTL conduziu os alunos à realização de atividades com caráter colaborativo, com forte influência do processamento social tutorial, em parte devido à interação dos mesmos com o líder-par. O que, entretanto, não os impediu de flertar com momentos de individualismo e até mesmo de competição.

Com relação aos resultados encontrados, referentes à disciplina na qual foram aplicadas ambas as estratégias em questão, estes indicam que algumas das interações discursivas nos grupos estão atreladas às suas características estruturais. De fato, a existência dos grupos de especialistas na estratégia cooperativa jigsaw, embora não influencie as funções de fala do primeiro bloco, repercute principalmente em algumas das funções de fala do segundo bloco (organização de ação e avaliação) e do terceiro bloco (citação crítica e organização de ideia).

No que se refere à segunda e à terceira dimensão de análise, percebemos que a aplicação da estratégia colaborativa PLTL, pouco estruturada e com a formação não heterogênea de grupos, repercutiu nos valores não regulares encontrados para os tipos de processamentos cognitivos e de processamentos sociais. Assim, foi observado que os resultados dependem, de forma significativa, das características dos membros dos grupos. A presença do líder-par, que leva os alunos a migrarem de um comportamento colaborativo para um tutorial, também foi determinante para a obtenção dos referidos valores.

De forma geral, é ainda possível afirmar, com base no uso recorrente das funções de fala que compõem o primeiro bloco (interrogação, resposta, complemento de resposta, informação e leitura em voz alta), que os alunos se mantiveram dedicados à resolução das atividades tanto nas turmas nas quais foi aplicada a estratégia jigsaw, quanto nas que foi aplicada a estratégia PLTL. Da 
mesma forma, o uso, mesmo que restrito, da função de fala do tipo afetiva nas referidas turmas indica que os alunos encontraram um ambiente seguro nas atividades nelas realizadas.

Os resultados obtidos corroboram ainda algumas das potencialidades das atividades cooperativas e colaborativas em ambientes de ensino-aprendizagem de Ciências, como a promoção da aprendizagem de conceitos científicos, o desenvolvimento de habilidades interpessoais e a instauração de um ambiente universitário acolhedor. Ademais, também evidenciam fragilidades da metodologia empregada, como a impossibilidade de verificação sobre as interações estabelecidas em um plano que não é o verbal, e adequação do Modelo Analítico adotado neste trabalho.

Embora 0 percurso trilhado nesta pesquisa tenha ocorrido com embasamento teórico, temos ciência das limitações a ela inerentes e acreditamos que as considerações aqui tecidas não devem ser entendidas de forma estanque. Em contraponto, o conhecimento alcançado pode subsidiar interpretações sobre a forma como diferentes elementos interferem na execução das estratégias investigadas e levar o leitor a ponderar a respeito, promovendo atividades didáticas exitosas. Além disso, esperamos também contribuir para o desencadeamento de ações em ambientes universitários pautadas em atividades em grupos cooperativos e colaborativos, ainda tão escassas no nosso país. 


\section{REFERÊNCIAS BIBLIOGRÁFICAS}

ANDERSON, W. L.; MITCHELL, S. M.; OSGOOD, M. P. Comparison of student performance in cooperative learning and traditional lecture-based biochemistry classes. Biochemistry and Molecular Biology Education, v. 33, n. 6, p. 387-393, 2005.

ARMSTRONG, N.; CHANG, S.; BRICKMAN, M. Cooperative learning in industrialsized biology classes. Cell Biology Education, v. 6, n. 2, p. 163-171, 2007.

ARONSON, E. The jigsaw classroom. Beverly Hills: Sage, 1978.

ATKINS, P.W.; JONES, L. Princípios de química: questionando a vida moderna e o meio ambiente. 3. ed. Porto Alegre: Bookman, 2006.

BARBOSA, R. M. N.; JÓFILI, Z. M. S. Aprendizagem cooperativa e ensino de química - parceria que dá certo. Ciência \& Educação, v. 10, n. 1, p. 55-61, 2004.

BARBOSA, R.; JÓFILI, Z.; WATTS, M. Cooperating in constructing knowledge: case studies from chemistry and citizenship. International Journal of Science Education, v. 26, n. 8, p. 935-949, 2004.

BELL, T.; URHAHNE, D.; SCHANZE, S.; PLOETZNER, R. Collaborative inquiry learning: models, tools, and challenges. International Journal of Science Education, v. 32, n. 3, p. 349-377, 2010.

BERGER, R.; HANZE, M. Comparison of two small-group learning methods in 12th-grade physics classes focusing on intrinsic motivation and academic performance. International Journal of Science Education, v. 31, n. 11, p. 15111527, 2009.

BERLAN, L. K.; LEE, V. R. In pursuit of consensus: disagreement and legitimization during small-group argumentation. International Journal of Science Education, v. 34, n. 12, p. 1857-1882, 2012.

CAROBIN, C.; SERRANO, A. Uma revisão das concepções alternativas em Equilíbrio Químico dentro do enfoque dos diferentes níveis de representação. Acta Scientiae, v. 9, n. 2, p. 131-143, 2007.

CARVALHO, A. M. P. Ensino de Ciências: unindo a pesquisa e a prática. São Paulo: Pioneira Thomson Learning, 2006. p.154.

COCHITO, M. I. S. Cooperação e aprendizagem: educação intercultural. Lisboa: ACIME, 2004.

COSTA, A. R.; OLIVEIRA, J. P.; ALVES, J. M. Analisando a construção de explicações individuais e coletivas em aulas sobre ligações iônicas, na 8a série. Revista Electrónica de Enseñanza de las Ciencias, v. 7, n. 1, p. 86-106, 2008. 
DILLENBOURG, P. What do you mean by collaborative learning? In:

DILLENBOURG, P. (Ed). Collaborative-learning: cognitive and computational approaches. Oxford: Elsevier, 1999. p. 1-19.

DOYMUS, K. Effects of a cooperative learning strategy on teaching and learning phases of matter and one-component phase diagrams. Journal of Chemical Education, v. 84, n. 11, p. 1857-1860, 2007.

DURÁN, S. R.; SÁNCHEZ-GUZMÁN, D. El cálculo de la fuerza resultante de un par de fuerzas sobre un punto fijo por los estudiantes de secundaria mediante técnicas colaborativas. Latin American Journal of Physics Education, v. 4, n. 1, p. 10441050, 2010.

FERNÁNDEZ-SANTANDER, A. Cooperative learning combined with short periods of lecturing. Biochemistry and Molecular Biology Education, v.36, n.1, p.34-38, 2008.

FIGUEIREDO, F. J. Q. (org.). A aprendizagem colaborativa de línguas. Goiânia: Editora UFG, 2006.

FOURLAS, G.; WRAY, D. Children's oral language: a comparison of two classroom organisational systems. In: Wray, D. (Ed.). Emerging partnerships, current research in language and literacy. Clevedon: Multilingual Matters, 1990, p. 76-86.

FRANÇA, A. C. G.; MARCONDES, M. E. R.; CARMO, M. P. Estrutura atômica e formação dos íons: uma análise das ideias dos alunos do $3^{\circ}$ ano do ensino médio. Química Nova na Escola, v. 31, n. 4, p. 275-282, 2009.

FURIÓ, C.; CARNICER, J. El desarrollo profesional del profesor de ciencias mediante tutorías de grupos cooperativos. Estudio de ocho casos. Enseñanza de las Ciencias, v. 20, n. 1, p. 47-73, 2002.

GAFNEY, L.; VARMA-NELSON, P. Peer-Led Team Learning: evaluation, dissemination, and institutionalization of a college level initiative. Dordrecht: SpringerVerlag, 2008.

GARCÍA, A. G.; TUÑÓN, M. J. I. El ciclo reflexivo cooperativo: un modelo didáctico para la enseñanza de las ciencias. Revista Electrónica de Enseñanza de las Ciencias, v. 3, n. 2, p. 148-160, 2004.

GOSSER JR, D. K.; KAMPMEIER, J. A.; VARMA-NELSON, P. Peer-Led Team Learning: 2008 James Flack Norris Award Address, Journal of Chemical Education, v. 87, n. 4, p. 374-380, 2010.

HONG, Z. Effects of a collaborative science intervention on high achieving students' learning anxiety and attitudes toward science. International Journal of Science Education, v. 32, n. 15, p. 1971-1988, 2010. 
JENSEN, J. L.; LAWSON, A. Effects of collaborative group composition and inquiry instruction on reasoning gains and achievement in undergraduate biology. Cell Biology Education, v. 10, n. 1, p. 64-73, 2011.

JOHNSON, D. W., JOHNSON, R.T. Cooperation and competition: theory and research. Edina: Interaction Book Company, 1989.

JOHNSON, D. W.; JOHNSON, R. T.; HOLUBEC, E. J. Los nuevos círculos del aprendizaje: la cooperación en el aula y la escuela. Virginia: Aique, 1999.

JOHNSON, D.W.; JOHNSON, R. T.; SMITH, K. The state of cooperative learning in postsecondary and professional settings. Educational Psychology Review, v. 19, n. 1, p.15-29, 2007.

JOHNSTONE, A. H. Macro and micro-chemistry. The School Science Review, v. 64, n. 227, p. 377-379, 1982.

KIM, M.; TAN, H. T. A collaborative problem-solving process through environmental field studies. International Journal of Science Education, v. 35, n. 3, p. 357-387, 2013.

KUMPULAINEN, K. The nature of children's oral language interactions during collaborative writing experience at the computer. 1994. Tese (Ph. D.) - University of Exeter, Exeter, 1994.

KUMPULAINEN, K. The nature of peer interaction in the social context created by the use of word processors. Learning and Instruction, v. 6, n. 3, p. 243-261, 1996.

KUMPULAINEN, K.; MUTANEN, M. Collaborative practice of science construction in a computer-based multimedia environment. Computers \& Education, v. 30, n. 1-2, p. 75-85, 1998.

KUMPULAINEN, K.; MUTANEN, M. The situated dynamics of peer group interaction: an introduction to an analytic framework. Learning and Instruction, v. 9, n. 5, p. 449-473, 1999.

LÜDKE, M.; ANDRÉ, M. E. D. A. Pesquisa em educação: abordagens qualitativas. São Paulo: Editora Pedagógica e Universitária Ltda., 1986.

MAHAN, B. M.; MYERS, R. J. Química: um curso universitário. São Paulo: Edgard Blücher, 1995.

MEGID NETO, Jorge. Tendências da pesquisa acadêmica sobre o ensino de ciências no nível fundamental. 1999. 365 f. Tese (Doutorado) - Faculdade de Educação, Universidade Estadual de Campinas, Campinas, 1999.

OLIVEIRA, J. R. S.; QUEIROZ, S. L. Comunicação e linguagem científica: guia para estudantes de química. Campinas: Átomo, 2007. 
PRESZLER, R. W. Replacing lecture with peer-led workshops improves student learning. Cell Biology Education, v. 8, p. 182-192, 2009.

REZENDE, F.; CASTELLS, M. Interanimation of voices and argumentative strategies in collaborative knowledge building of Physics teachers in an asynchronous discussion group. Revista Electrónica de Enseñanza de las Ciencias, v. 9, n. 2, p. 396-417, 2010.

RIBEIRO JÚNIOR, R. M.; ECHEVERRÍA, A. R. Grupos de estudos entre estudantes ingressantes (calouros) e veteranos: uma perspectiva alternativa de estudo e discussão na universidade. Química Nova na Escola, v. 31, n. 2, p. 132-139, 2009.

SANDI-URENA, S.; COOPER, M. M.; STEVENS, R. H. Enhancement of metacognition use and awareness by means of a collaborative intervention. International Journal of Science Education, v. 33, n. 3, p. 323-340, 2011.

SEIFERT, K.; FENSTER, A.; DILTS, J. A.; TEMPLE, L. An investigative, cooperative learning approach to the general microbiology laboratory. Cell Biology Education, v. 8, n. 2, p. 147-153, 2009.

SHE, H. Students' knowledge construction in small groups in the seventh grade biology laboratory: verbal communication and physical engagement. International Journal of Science Education, v. 21, n. 10, p. 1051-1066, 1999.

SILVA, O. B.; QUEIROZ, S. L. Mapeamento da pesquisa no campo da formação de professores de química no Brasil. Investigações em Ensino de Ciências, v. 21, n. 1, p. 62-93, 2016.

SLAVIN, R. E. Cooperative learning. New York: Longmann, 1983.

TANNER, K.; CHATMAN, L. S.; ALLEN, D. Approaches to cell biology teaching: cooperative learning in the science classroom - beyond students working in groups.

Cell Biology Education, v. 2, n. 1, p. 1-5, Spring 2003.

TEODORO, D. L. Aprendizagem cooperativa no ensino de química: investigando uma atividade didática elaborada no formato jigsaw. 119 f. Dissertação (Mestrado em Química) - Instituto de Química de São Carlos, Universidade de São Paulo, São Carlos, 2011.

TEODORO, D. L.; CABRAL, P. F. O.; QUEIROZ, S. L. Atividade cooperativa no formato jigsaw: um estudo no Ensino Superior de Química. Alexandria: Revista de Educação em Ciência e Tecnologia, v. 8, n. 1, p. 21-51, 2015.

THURSTON, A.; TOPPING, K. J.; TOLMIE, A.; CHRISTIE, D.; KARAGIANNIDOU, E.; MURRAY, P. Cooperative learning in science: follow-up from Primary to High School. International Journal of Science Education, v. 32, n. 4, p. 501-522, 2010.

VALVERDE, G. J.; JIMÉNEZ, R. L.; VIZA, A. L. Los niveles de abertura en las prácticas cooperativas de química, Revista Electrónica de Enseñanza de las Ciencias, v. 4, n. 3, p. 1-26, 2005. 
VALVERDE, G. J.; VIZA, A. L. Deducción de calificaciones individuales en actividades cooperativas: una oportunidad para la coevaluación y la autoevaluación en la enseñanza de las ciencias. Revista Eureka sobre Enseñanza y Divulgación de las Ciencias, v. 3, n. 2, p. 172-187, 2006.

VALVERDE, G. J.; VIZA, A. M. L. Optimización metodológica de entornos telemáticos cooperativos (BSCW y SINERGEIA) como recursos didácticos de la química en la producción de hipermedia. Enseñanza de las Ciencias, v. 26, n. 1, p. 93-106, 2008.

VENVILLE, G. Powerful knowledge and quality talk: maximising learning of genetics during collaborative group work. Cultural Studies of Science Education, v. 4, n. 1, p. 201-209, 2009.

VIDAL, D. G. Da caligrafia à escrita: experiências escolanovistas com caligrafia muscular nos anos 30. Revista da Faculdade de Educação, v. 24, n. 1, p. 126-140, 1998.

ZUCCO, C.; PESSINE, F. B. T.; ANDRADE, J. B. Diretrizes curriculares para os cursos de química. Química Nova, v. 22, n. 3, p. 454-461, 1999. 


\section{APÊNDICE A}

\section{Revistas analisadas}

\section{Qualis A1}

Ciência e Educação (UNESP. Impresso)

Cultural Studies of Science Education (Print)

Enseñanza de las Ciencias

International Journal of Science Education

Physics Education (Bristol. Print)

Research in science \& technological education

Science \& Education (Dordrecht)

Chemistry Education. Research and Practice in Europe

International Journal of Science and Mathematical Education

Journal of Research in Science Teaching (Print)

Journal of Science Education and Technology

Research in Science Education

Science Education International (Online)

Science Studies (Tampere)

Studies in Science Education

Chemical Education Journal

European Journal of Physics (Print)

Journal of Chemical Education

Public Understanding of Science (Print)

Revista de Educacion de las Ciencias

\section{Qualis A2}

American Journal of Physics

Biochemistry and Molecular Biology Education

Cadernos CEDES (Impresso)

Cell Biology Education

Ensaio: Pesquisa em Educação em Ciências (Impresso)

Enseñanza de las Ciencias de la Tierra

Investigações em Ensino de Ciências (Online)

Investigações em Ensino de Ciências (UFRGS. Impresso)

Journal of Biological Education

Philosophy of Science (East Lansing)

Public Understanding of Science (Print)

REEC. Revista Electrónica de Enseñanza de las Ciencias

Revista de Enseñanza de la Física

Revista Brasileira de História da Ciência

Revista Brasileira de Pesquisa em Educação em Ciências

Science in Context

Studies In History and Philosophy of Modern Physics

Revista Brasileira de Ensino de Física online e imprresso 


\section{Qualis B1}

Revista Eureka sobre Enseñanza y Divulgación de las Ciencias

\section{Qualis B2}

Alexandria (UFSC)

Educação e Pesquisa

Experiências em Ensino de Ciências (UFRGS) Latin American Journal of Physics Education Revista Brasileira de Educação (Impresso)

Revista Brasileira de Informação na Educação

Revista Chilena de Educación Científica

Revista de la Facultad de Ciencia y Tecnologia 


\section{APÊNDICE B}

\section{Termo de Consentimento e Informação}

Nome da Pesquisa: Aprendizagem Cooperativa e Colaborativa no Ensino de Química.

Pesquisadora responsável: Profa. Dra. Salete Linhares Queiroz

Informações sobre a pesquisa: Por meio de leituras, discussões realizadas durante as atividades em grupo e do material escrito produzido pelos alunos (durante as atividades extraclasse da disciplina Cinética Química: Teoria e Prática, ministradas no ano de 2012) deseja-se identificar características inerentes à aprendizagem cooperativa e colaborativa objetivando discutir as suas potencialidades no Ensino de Química.

Assim, convidamos você, aluno de graduação em química no terceiro ano, a participar deste estudo. Assumimos o compromisso de manter sigilo quanto a sua identidade, como também garantimos que o desenvolvimento da pesquisa foi planejado de forma a não produzir riscos ou desconforto para os participantes. Pedimos também autorização para gravar (gravação em áudio e vídeo) o que for falado durante as aulas.

Profa. Dra. Salete Linhares Queiroz 
Eu,

RG abaixo assinado, tendo recebido as informações acima, e ciente dos meus direitos, concordo em participar da referida pesquisa, bem como ter:

1. A garantia de receber todos os esclarecimentos sobre todas as discussões antes e durante o desenvolvimento da pesquisa podendo afastar-me a qualquer momento assim que desejar.

2. A segurança plena de que não serei identificado, mantendo o caráter oficial da informação, assim como está assegurado que a pesquisa não acarretará nenhum prejuízo individual ou coletivo.

3. A segurança de que não terei nenhum tipo de despesa material ou financeira durante o desenvolvimento da pesquisa, bem como esta pesquisa não causará nenhum tipo de risco, dano físico, ou mesmo constrangimento moral e ético.

4. A garantia de que toda e qualquer responsabilidade nas diferentes fases da pesquisa é dos pesquisadores, bem como fica assegurado que haverá ampla divulgação dos resultados finais nos meios de comunicação e nos órgão de divulgação científica em que a mesma seja aceita.

5. A garantia de que todo material resultante será usado exclusivamente para a construção da pesquisa e ficará sob guarda dos pesquisadores.

Tendo ciência do exposto acima, desejo participar da pesquisa.

São Calos, de de 2012. 


\section{APÊNDICE C}

Nome completo:

Idade:

\section{BLOCO 1}

1) Quais foram os motivos que levaram você a prestar vestibular para o curso de Bacharelado em Química?

2) Já tinha contato com algum profissional da área de Química? Se sim, com quem?

3) O que você acredita que um profissional da Química deve "saber" e "saber fazer" para ser bem sucedido na sua profissão?

4) Onde você realizou o ensino fundamental?

( ) Rede Pública ( ) Rede Privada ( ) Parte na Rede Pública e parte na Rede Privada

5) Onde você realizou o ensino médio?

( ) Rede Pública ( ) Rede Privada ( ) Parte na Rede Pública e parte na Rede Privada

6) Você teve alguma outra experiência durante ou após esse período (outro curso de graduação, curso técnico-profissionalizante, etc.). Se sim, especifique.

\section{BLOCO 2}

1) O modelo científico para representação do átomo mostra como a ciência química evoluiu no decorrer da história. Usando seu conhecimento escreva as etapas e os nomes dos cientistas que contribuíram para o desenvolvimento do modelo atual.

2) Elabore, com base em seus conhecimentos, um desenho que mostre como você imagina "ser" um átomo, indicando as partes que o constituem.

3) Quais fatores são usados para separar os elementos na tabela periódica?

4) Podemos separar os elétrons de um átomo? Explique.

5) O fato de um átomo perder ou ganhar elétrons pode afetar seu volume atômico, explique essa relação.

6) Defina o que é química orgânica e faça sua correlação com a química inorgânica?

7) As ligações químicas podem apresentar um caráter iônico, covalente ou metálico, indique como podemos diferenciar esse caráter em substâncias diferentes?

\section{BLOCO 3}

1)Durante a sua vida estudantil você realizou trabalhos em grupo? ( )Sim ( )Não

2) Se sim, com qual frequência (quantas vezes em média, por ano)?

3) Em quais ocasiões (quais atividades, quais disciplinas) foi solicitada a sua participação, na escola, em trabalhos em grupo?

4) O trabalho em grupo, na escola, agrada a você? ( )Sim ( )Não. Justifique sua resposta. 


\section{APÊNDICE D}

\section{Termo de Consentimento e Informação}

Nome da Pesquisa: Aprendizagem Cooperativa e Colaborativa no Ensino de Química.

Pesquisadora responsável: Profa. Dra. Salete Linhares Queiroz

Informações sobre a pesquisa: Por meio de leituras, discussões realizadas durante as atividades em grupo e do material escrito produzido pelos alunos (durante as atividades extraclasse da disciplina Introdução à Química, ministradas no ano de 2013) deseja-se identificar características inerentes à aprendizagem cooperativa e colaborativa objetivando discutir as suas potencialidades no Ensino de Química.

Assim, convidamos você, aluno de graduação em química no primeiro ano, a participar deste estudo. Assumimos o compromisso de manter sigilo quanto a sua identidade, como também garantimos que o desenvolvimento da pesquisa foi planejado de forma a não produzir riscos ou desconforto para os participantes. Pedimos também autorização para gravar (gravação em áudio e vídeo) o que for falado durante as aulas.

Profa. Dra. Salete Linhares Queiroz 
Eu,

RG abaixo assinado, tendo recebido as informações acima, e ciente dos meus direitos, concordo em participar da referida pesquisa, bem como ter:

1. A garantia de receber todos esclarecimentos sobre todas as discussões antes e durante o desenvolvimento da pesquisa podendo afastar-me a qualquer momento assim que desejar.

2. A segurança plena de que não serei identificado, mantendo o caráter oficial da informação, assim como está assegurado que a pesquisa não acarretará nenhum prejuízo individual ou coletivo.

3. A segurança de que não terei nenhum tipo de despesa material ou financeira durante o desenvolvimento da pesquisa, bem como esta pesquisa não causará nenhum tipo de risco, dano físico, ou mesmo constrangimento moral e ético.

4. A garantia de que toda e qualquer responsabilidade nas diferentes fases da pesquisa é dos pesquisadores, bem como fica assegurado que haverá ampla divulgação dos resultados finais nos meios de comunicação e nos órgão de divulgação científica em que a mesma seja aceita.

5. A garantia de que todo material resultante será usado exclusivamente para a construção da pesquisa e ficará sob guarda dos pesquisadores.

Tendo ciência do exposto acima, desejo participar da pesquisa.

São Calos, de de 2013. 


\section{APÊNDICE E}

\section{Tarefa: Grupos de Base 1}

Questionário

1. O que você entende por natureza dinâmica do equilíbrio químico?

2. Como a temperatura e a concentração podem afetar o equilíbrio químico?

3. Defina com suas palavras o efeito do íon comum.

4. O equilíbrio químico da substancia água pode ajudar a definir ácidos, bases e $\mathrm{pH}$ ? Se sim indique como.

5. Já fez titulação alguma vez, como ela funciona? 


\section{APÊNDICE F}

\section{Tarefa: Grupo de Especialistas}

\section{ASSINATURA DOS MEMBROS:}

Todos os membros do grupo de especialistas estudaram o mesmo tipo de tópico e como tarefa de casa na semana passada buscaram aprofundar seus conhecimentos sobre seu tópico, afim de, contribuir para atividade no grupo de especialistas. $\mathrm{Na}$ atividade de hoje os alunos resolverão um questionário sobre seu tópico:

\section{Questionário Equilíbrio Químico}

1. Relacione a natureza dinâmica do equilíbrio químico com a reversibilidade das reações químicas.

2. A natureza termodinâmica do equilíbrio químico coloca em confronto duas tendências da matéria, a entropia máxima e a energia mínima. Discuta e defina como elas agem no equilíbrio.

3. Quais fatores podem influenciar um equilíbrio químico?

4. Uma perturbação pode afetar a espontaneidade do equilíbrio?

5. Por que a expressão de equilíbrio só vale para gases ideais e solutos que obedecem à teoria das soluções ideais.

\section{Questionário Efeito do Íon Comum}

1. Relacione a expressão da constante de equilíbrio com a expressão do produto de solubilidade.

2. Explique por que os equilíbrios iônicos são sempre trabalhados com sais poucos solúveis.

3. Quando se adiciona um íon comum a uma solução ocorre uma perturbação que permite considerar a concentração do íon adicionado como a concentração total do íon em solução. O que nos permite fazer essa aproximação?

4. A solubilidade de $\mathrm{AgCl}$ em água pura é igual a $1,8 \times 10^{-10} \mathrm{M}$. A solubilidade deste sal em uma solução $1,5 \times 10^{-2} \mathrm{M}$ de $\mathrm{AgNO}_{3}$, será maior ou menor do que $1,8 \times 10^{-10}$ M? Por quê?

5. Explique por que temos que saber a expressão de solubilidade e a estequiometria da reação para calcular o efeito de um íon comum. 


\section{Questionário Ácidos e Bases}

1. As modificações na teoria ácido-base teve como objetivo sanar algumas limitações e ao mesmo tempo ampliar seu uso. Diferencie as teorias de Arrhenius, Bronsted e Lowry e Lewis, baseado nessa premissa.

2. Defina o que é um par ácido-base conjugado.

3. Como podemos medir a força de um ácido ou base, o meio onde ele se encontra é importante para definir sua força? Por quê?

\section{Questionário Titulação}

1. Defina titulação ácido-base.

2. É possível usar o principio de Le Chatelier e a definição de equilíbrio químico para explicar a Titulação?

3. Ponto de equivalência, indicador e padrão primário são termos fundamentais na titulação, sabendo disso descreva de forma concisa cada um deles e explique como eles se relacionam. 


\section{APÊNDICE G}

\section{Tarefa: Grupos de Base 2}

\section{Questionário Geral}

1. Relacione a natureza dinâmica do equilíbrio químico com a reversibilidade das reações químicas.

2. Uma solução Tampão pode ser usada como gatilho de defesa no nosso organismo, como isso ocorre?

3. Ponto de equivalência, indicador e padrão primário são termos fundamentais na titulação, sabendo disso descreva de forma concisa cada um deles e como eles se relacionam.

4. Por que a expressão de equilíbrio só vale para gases ideais e solutos que obedecem à teoria das soluções ideais. Defina o Princípio de Le Chatelier.

5. Defina o que é um par ácido-base conjugado. 


\section{ANEXO A}

DISCIPLINA: - Cinética Química

\section{EXERCICIOS - LISTA 1}

1. Ao dissolver $\beta$-glucose em água, esta começa a se transformar em $\alpha$-glucose.

$\beta$-glucose $\alpha$-glucose

Num estudo dessa reação, as leituras dos ângulos de rotação lidas num polarímetro foram:

\begin{tabular}{c|c|c|c|c|c|c|c|c}
\hline $\boldsymbol{t}(\boldsymbol{m i n})$ & 20 & 40 & 60 & 80 & 100 & 120 & 360 & 1440 \\
\hline $\boldsymbol{\theta}$ & 10,8 & 13,3 & 15,1 & 16,4 & 17,5 & 18,2 & 20,3 & 20,4 \\
(graus) & & & & & &
\end{tabular}

Determine a ordem da reação, calcule a constante de velocidade e a meia-vida.

2. A dimerização do butadieno $2 \mathrm{Bu} \longrightarrow \mathrm{Bu}_{2}$ em fase gasosa é uma reação de ordem dois. Num estudo da cinétic desta reação a $326^{\circ} \mathrm{C}$, e com uma pressão inicial de butadieno igual a 632 torr, foram obtidos os seguintes valores de pressão total:

\begin{tabular}{c|c|c|c|c|c|c|c|c}
\hline $\boldsymbol{t}$ (min) & 0 & 6 & 10 & 14 & 29 & 61 & 90 & 135 \\
\hline $\boldsymbol{p}$ (torr) & 632 & 607 & 592 & 576 & 535 & 483 & 453 & 423 \\
\hline
\end{tabular}

Calcule o valor da constante de velocidade em unidades de $t o r r^{-1} \cdot \mathrm{min}^{-1} \mathrm{e} L \cdot \mathrm{mol}^{-1} \cdot \mathrm{min}^{-1}$.

3. A decomposição térmica do éter dimetílico na fase gasosa,

$$
\mathrm{CH}_{3} \mathrm{OCH}_{3} \longrightarrow \mathrm{CH}_{4}+\mathrm{H}_{2}+\mathrm{CO}
$$

foi estudada com medidas de pressão a $504^{\circ} \mathrm{C}$, e pressão inicial de éter igual a 312 torr. Os dados obtidos foram:

\begin{tabular}{c|c|c|c|c|c}
\hline tempo (s) & 390 & 777 & 1195 & 3155 & $\infty$ \\
\hline $\begin{array}{c}\text { aumento de pressão } \\
\text { (torr) }\end{array}$ & 96 & 176 & 250 & 467 & 619 \\
\hline
\end{tabular}

Determinar a ordem da reação e o valor da constante de velocidade.

4. O cloreto de benzildiazônio decompõe-se de acordo com a reação:

$$
\mathrm{C}_{6} \mathrm{H}_{5} \mathrm{~N}_{2} \mathrm{Cl} \longrightarrow \mathrm{C}_{6} \mathrm{H}_{5} \mathrm{Cl}+\mathrm{N}_{2}
$$

Em um experimento a $50{ }^{\circ} \mathrm{C}$, com uma concentração inicial de reagente igual a 10 g. $\mathrm{L}^{-1}$, foram obtidos os seguintes resultados:

\begin{tabular}{c|c|c|c|c|c|c|c|c}
\hline $\boldsymbol{t}(\boldsymbol{m i n})$ & 0 & 6 & 9 & 12 & 18 & 24 & 30 & $\infty$ \\
\hline $\begin{array}{c}\text { volume de } \boldsymbol{N}_{\mathbf{2}} \\
\left(\mathbf{c m}^{3}\right)\end{array}$ & 0 & 19,3 & 26,0 & 32,6 & 41,3 & 46,5 & 50,4 & 58,3 \\
\hline
\end{tabular}

Determinar a ordem e a constante de velocidade para este sistema.

5. A reação de iodação do nitroetano em presença de piridina ocorre de acordo com a seguinte equação química: 


$$
\mathrm{C}_{2} \mathrm{H}_{5} \mathrm{NO}_{2}+\mathrm{C}_{5} \mathrm{H}_{5} \mathrm{~N}+\mathrm{I}_{2} \longrightarrow \mathrm{C}_{2} \mathrm{H}_{4} \mathrm{INO}_{2}+\mathrm{C}_{5} \mathrm{H}_{5} \mathrm{NH}^{+}+\mathrm{I}^{-}
$$

A reação foi estudada por medidas condutométricas.

\begin{tabular}{c|c|c|c|c|c|c|c|c}
\hline $\boldsymbol{t}$ (min) & 0 & 5 & 10 & 15 & 20 & 25 & 30 & $\infty$ \\
\hline $\begin{array}{c}\text { resistência } \\
\text { (ohms) }\end{array}$ & 2503 & 2295 & 2125 & 1980 & 1850 & 1738 & 1639 & 1470 \\
\hline
\end{tabular}

As concentrações iniciais dos reagentes foram:

$\left[\mathrm{C}_{2} \mathrm{H}_{5} \mathrm{NO}_{2}\right]=0,1 \mathrm{~mol} \cdot \mathrm{L}^{-1}$

$\left[\mathrm{C}_{5} \mathrm{H}_{5} \mathrm{~N}\right]=0,1 \mathrm{~mol} \cdot \mathrm{L}^{-1}$

$\left[\mathrm{I}_{2}\right]=0,0045 \mathrm{~mol} \cdot \mathrm{L}^{-1}$

Determine a ordem aparente da reação e a constante aparente em unidades apropriadas.

Supondo ordem um para a piridina e para o nitroetano, obtenha o valor da constante verdadeira.

6. A reação:

$$
\mathrm{C}_{6} \mathrm{H}_{5} \mathrm{CH}=\mathrm{CHCHCl}_{2}+\mathrm{C}_{2} \mathrm{H}_{5} \mathrm{O}^{-} \longrightarrow \mathrm{C}_{6} \mathrm{H}_{5} \mathrm{CH}=\mathrm{CHCl}+\mathrm{Cl}^{-}
$$

foi estudada espectrofotometricamente no comprimento de onda $2600 \AA$, onde o reagente (cloreto de cinamol) absorve, mas o produto não. Quando se estudou a reação em álcool absoluto, a $22,6{ }^{\circ} \mathrm{C}$ e com concentrações iniciais: $\left[\mathrm{RCl}_{2}\right]=2,11 \times 10^{-5} \mathrm{~mol}^{-\mathrm{L}^{-1} \mathrm{e}}$ $[E t O N a]=0,547 \mathrm{~mol} \cdot \mathrm{L}^{-1}$, foram feitas as seguintes leituras no espectrofotômetro:

\begin{tabular}{c|c|c|c|c|c|c|c}
\hline $\boldsymbol{t}$ (min) & 0 & 10 & 31 & 74 & 127 & 178 & 1200 \\
\hline $\boldsymbol{A}=\boldsymbol{c} \boldsymbol{b} \boldsymbol{c}$ & 0,41 & 0,38 & 0,34 & 0,26 & 0,18 & 0,14 & 0,01 \\
\hline
\end{tabular}

Calcule a ordem aparente, a constante de velocidade aparente e a constante verdadeira.

7. Os dados abaixo referem-se à decomposição do vapor de óxido de etileno em metano e monóxido de carbono, a $414,5^{\circ} \mathrm{C}$ :

\begin{tabular}{c|c|c|c|c|c|c}
\hline $\boldsymbol{t}$ (min) & 0 & 5 & 7 & 9 & 12 & 18 \\
\hline $\boldsymbol{p}$ (torr) & 116,50 & 122,56 & 125,72 & 128,74 & 133,23 & 141,37 \\
\hline
\end{tabular}

Mostrar que a decomposição segue uma reação de ordem 1, e calcular a constante específica de velocidade.

8. A decomposição catalisada de $\mathrm{H}_{2} \mathrm{O}_{2}$ em solução aquosa é uma reação de ordem 1 , e foi estudada mediante a titulação de $\mathrm{H}_{2} \mathrm{O}_{2}$ não decomposta com uma solução de $\mathrm{KMnO}_{4}$. Determinar graficamente o valor da constante específica de velocidade.

\begin{tabular}{c|c|c|c|c|c|c}
\hline $\boldsymbol{t}(\boldsymbol{m i n})$ & 0 & 5 & 10 & 20 & 30 & 50 \\
\hline $\begin{array}{c}\text { volume de } \mathrm{KMnO}_{4} \\
\left(\mathbf{c m}^{3}\right)\end{array}$ & 46,1 & 37,1 & 29,8 & 19,6 & 13,3 & 5,0 \\
\hline
\end{tabular}

9. A decomposição do cloroformiato de triclorometila, em estado gasoso, em fosgênio acontece de acordo com a reação: 
$\mathrm{ClCOOCCl}_{3}(\mathrm{~g}) \longrightarrow 2 \mathrm{COCl}_{2}(\mathrm{~g})$

A pressão do sistema foi medida em vários tempos, como mostra a tabela a seguir:

\begin{tabular}{c|c|c|c|c|c|c|c|c}
\hline $\boldsymbol{t}$ (min) & 0 & 51 & 206 & 454 & 751 & 1132 & 1575 & 2215 \\
\hline $\boldsymbol{p}$ (torr) & 15,03 & 15,48 & 16,74 & 18,57 & 20,33 & 22,27 & 23,98 & 25,89 \\
\hline
\end{tabular}

a) Determinar a ordem da reação.

b) Calcular sua constante específica de velocidade.

10. A velocidade da reação $A+B \rightarrow P$ foi seguida através de medidas da absorbância da solução em diferentes tempos, conforme a tabela:

\begin{tabular}{c|c|c|c|c|c|c|c|c}
\hline $\boldsymbol{t}$ (min) & 0 & 18 & 57 & 130 & 240 & 337 & 398 & $\infty$ \\
\hline $\boldsymbol{A b s}$ & 0,219 & 0,206 & 0,183 & 0,151 & 0,120 & 0,105 & 0,098 & 0,080 \\
\hline
\end{tabular}

A concentração inicial de $A$ foi igual a $0,001 \mathrm{M}$ e a concentração inicial de $\mathrm{B}$ igual a $1,00 \mathrm{M}$.

Em um outro experimento nas mesmas condições, mas com a concentração inicial de B igual a 2,00 M verificou-se que o valor da constante de velocidade observada teve um valor igual ao dobro do observado anteriormente.
a) Qual a ordem da reação?
b) Qual o valor das constantes de velocidade (observada e verdadeira)?
c) Qual o valor da meia vida da reação? 


\section{ANEXO B \\ DISCIPLINA: - Cinética Química}

\section{EXERCÍCIOS $-\underline{\text { LISTA } 2}$}

1. A decomposição de dióxido de nitrogênio é uma reação de ordem dois, com as seguintes constantes específicas para diferentes temperaturas:

\begin{tabular}{|c||c|c||c|c|c|}
\hline \hline $\mathrm{T} / \mathrm{K}$ & 592 & 603 & 627 & 652 & 656 \\
\hline $\mathrm{k} / \mathrm{cm}^{3} \cdot \mathrm{mol}^{-1} \cdot \mathrm{s}^{-1}$ & 522 & 755 & 1700 & 4020 & 5030 \\
\hline
\end{tabular}

Calcule a energia de ativação e o fator pré-exponencial.

2. Para a reação entre isocianeto de toloila e álcool n-butílico, foram determinadas as seguintes constantes específicas, em diferentes temperaturas:

\begin{tabular}{|c||c|c|c||c||}
\hline $\mathrm{T}\left({ }^{\circ} \mathrm{C}\right)$ & 0,0 & 7,0 & 15,0 & 25,0 \\
\hline \hline $\mathrm{k}\left(\mathrm{L} \cdot \mathrm{mol}^{-1} \cdot \mathrm{s}^{-1}\right)$ & $4,04 \times 10^{-5}$ & $7,72 \times 10^{-5}$ & $1,29 \times 10^{-4}$ & $2,50 \times 10^{-4}$ \\
\hline
\end{tabular}

Calcule a energia de ativação, e o fator pré-exponencial.

3. A decomposição unimolecular do etano forneceu os seguintes resultados:

\begin{tabular}{|c|c|c|c|c|c|}
\hline $\mathrm{T}\left({ }^{\circ} \mathrm{C}\right)$ & 550 & 570 & 590 & 610 & 630 \\
\hline $\mathrm{k}\left(10^{5} \cdot \mathrm{s}^{-1}\right)$ & 2,5 & 8,2 & 23,1 & 57,6 & 141,5 \\
\hline
\end{tabular}

Calcule a energia de ativação e o fator pré-exponencial.

4. Uma reação de ordem um avança $30 \%$ em 30 minutos, a $25^{\circ} \mathrm{C}$, e em 5 minutos a $40{ }^{\circ} \mathrm{C}$. Estime a energia de ativação.

5. A constante para a decomposição de $\mathrm{N}_{2} \mathrm{O}_{5}$ a $65{ }^{\circ} \mathrm{C}$ é $0,292 \mathrm{~min}^{-1}$ e a energia de ativação $24,7 \mathrm{kcal}^{\mathrm{mol}}{ }^{-1}$. Calcule $\mathrm{k} \mathrm{e} \mathrm{t} 1 / 2$ a $80^{\circ} \mathrm{C}$.

6. A decomposição térmica do dimetil éter segue a estequiometria:

$$
\mathrm{CH}_{3} \mathrm{OCH}_{3} \rightarrow \mathrm{CH}_{4}+\mathrm{H}_{2}+\mathrm{CO}
$$

$$
\mathrm{T}=504^{\circ} \mathrm{C}
$$$$
\mathrm{T}=552^{\circ} \mathrm{C}
$$ 


\begin{tabular}{|c||c|c|c||}
\hline $\mathrm{t}(\mathrm{s})$ & $\mathrm{p}$ (torr) & $\mathrm{t}(\mathrm{s})$ & $\mathrm{p}$ (torr) \\
\hline \hline 0 & 312 & 0 & 420 \\
\hline \hline 320 & 408 & 114 & 743 \\
\hline \hline 171 & 488 & 219 & 954 \\
\hline \hline 3155 & 562 & 299 & 1054 \\
\hline \hline$\infty$ & 779 & 543 & 1198 \\
\hline
\end{tabular}

Determine: a ordem da reação.

a constante de velocidade em cada temperatura.

a energia de ativação.

7. A hidrólise da sacarose, na qual uma molécula de sacarose é quebrada em uma molécula de glicose e uma molécula de frutose, é parte do processo digestivo. Quão fortemente a velocidade depende da temperatura de nosso corpo? Calcule a constante de velocidade para a hidrólise da sacarose a $35,0^{\circ} \mathrm{C}$, sabendo que $\mathrm{k}=1,0 \times 10-3 \mathrm{~L} \mathrm{~mol}^{-1} \mathrm{~s}^{-1}$ a $37{ }^{\circ} \mathrm{C}$ (temperatura normal do corpo) e que a energia de ativação é $108 \mathrm{~kJ} \mathrm{~mol}^{-1}$. (Química Geral Atkins)

8. Duas reações de ordem dois tem fatores pré-exponenciais $(A)$ idênticos, e energia de ativação $\left(E_{a}\right)$ diferindo por $20,0 \mathrm{~kJ} \mathrm{~mol}^{-1}$. Calcule a razão de suas constantes $(\mathrm{k})$ à: (a) $0{ }^{\circ} \mathrm{C}$, e (b) $1000^{\circ} \mathrm{C}$. Assumir que a equação de Arrenhenius seja valida para este caso. (Laidler)

9. A pulga d'água Daphnia possui um número constante de batimentos cardíacos e então morre. Sabendo-se que ela vive duas vezes mais a $15^{\circ} \mathrm{C}$ do que a $25^{\circ} \mathrm{C}$, Estime a energia de ativação para a reação que controla a velocidade destes batimentos cardíacos. (Laidler)

10. Uma amostra de leite mantida à $25^{\circ} \mathrm{C}$ forma soro quarenta vezes mais rápido do que quando mantida a $4,0^{\circ} \mathrm{C}$. Estime a energia de ativação para o processo. (Laidler) 


\section{ANEXO C \\ DISCIPLINA: - Cinética Química \\ EXERCÍCIOS - LISTA 3}

1. Ao dissolver $\beta$-glucose em água, esta começa a se transformar em $\alpha$-glucose.

$$
\beta \text {-glucose } \longrightarrow \alpha \text {-glucose }
$$

Num estudo dessa reação, as leituras dos ângulos de rotação lidas num polarímetro foram:

\begin{tabular}{c|c|c|c|c|c|c|c|c}
\hline $\boldsymbol{t}$ (min) & 20 & 40 & 60 & 80 & 100 & 120 & 360 & 1440 \\
\hline $\begin{array}{c}\boldsymbol{\theta} \\
\text { (graus) }\end{array}$ & 10,8 & 13,3 & 15,1 & 16,4 & 17,5 & 18,2 & 20,3 & 20,4 \\
\hline
\end{tabular}

Determine a ordem da reação, calcule a constante de velocidade e a meia-vida.

2. A dimerização do butadieno $2 \mathrm{Bu}$ $\mathrm{Bu}_{2}$ em fase gasosa é uma reação de ordem dois. Num estudo da cinétic desta reação a $326{ }^{\circ} \mathrm{C}$, e com uma pressão inicial de butadieno igual a 632 torr, foram obtidos os seguintes valores de pressão total:

\begin{tabular}{c|c|c|c|c|c|c|c|c}
\hline $\boldsymbol{t}$ (min) & 0 & 6 & 10 & 14 & 29 & 61 & 90 & 135 \\
\hline $\boldsymbol{p}$ (torr) & 632 & 607 & 592 & 576 & 535 & 483 & 453 & 423 \\
\hline
\end{tabular}

Calcule o valor da constante de velocidade em unidades de $t^{-1} r^{-1} \cdot \mathrm{min}^{-1} \mathrm{e}$ L. $\mathrm{mol}^{-1} \cdot \mathrm{min}^{-1}$.

3. A decomposição térmica do éter dimetílico na fase gasosa,

$$
\mathrm{CH}_{3} \mathrm{OCH}_{3} \longrightarrow \mathrm{CH}_{4}+\mathrm{H}_{2}+\mathrm{CO}
$$

foi estudada com medidas de pressão a $504^{\circ} \mathrm{C}$, e pressão inicial de éter igual a 312 torr. Os dados obtidos foram:

\begin{tabular}{c|c|c|c|c|c}
\hline tempo (s) & 390 & 777 & 1195 & 3155 & $\infty$ \\
\hline $\begin{array}{c}\text { aumento de pressão } \\
\text { (torr) }\end{array}$ & 96 & 176 & 250 & 467 & 619 \\
\hline
\end{tabular}

Determinar a ordem da reação e o valor da constante de velocidade.

4. O cloreto de benzildiazônio decompõe-se de acordo com a reação:

$$
\mathrm{C}_{6} \mathrm{H}_{5} \mathrm{~N}_{2} \mathrm{Cl} \longrightarrow \mathrm{C}_{6} \mathrm{H}_{5} \mathrm{Cl}+\mathrm{N}_{2}
$$

Em um experimento a $50^{\circ} \mathrm{C}$, com uma concentração inicial de reagente igual a 10 g. $\mathrm{L}^{-1}$, foram obtidos os seguintes resultados:

\begin{tabular}{l|l|l|l|l|l|l|l|l}
\hline $\boldsymbol{t}(\boldsymbol{m i n})$ & 0 & 6 & 9 & 12 & 18 & 24 & 30 & $\infty$ \\
\hline
\end{tabular}




\begin{tabular}{c|c|c|c|c|c|c|c|c}
\hline $\begin{array}{c}\text { volume de } \boldsymbol{N}_{\mathbf{2}} \\
\left(\mathbf{c m}^{\mathbf{3}}\right)\end{array}$ & 0 & 19,3 & 26,0 & 32,6 & 41,3 & 46,5 & 50,4 & 58,3 \\
\hline
\end{tabular}

Determinar a ordem e a constante de velocidade para este sistema.

5. A reação de iodação do nitroetano em presença de piridina ocorre de acordo com a seguinte equação química:

$$
\mathrm{C}_{2} \mathrm{H}_{5} \mathrm{NO}_{2}+\mathrm{C}_{5} \mathrm{H}_{5} \mathrm{~N}+\mathrm{I}_{2} \longrightarrow \mathrm{C}_{2} \mathrm{H}_{4} \mathrm{INO}_{2}+\mathrm{C}_{5} \mathrm{H}_{5} \mathrm{NH}^{+}+\mathrm{I}^{-}
$$

A reação foi estudada por medidas condutométricas.

\begin{tabular}{c|c|c|c|c|c|c|c|c}
\hline $\boldsymbol{t}(\boldsymbol{m i n})$ & 0 & 5 & 10 & 15 & 20 & 25 & 30 & $\infty$ \\
\hline $\begin{array}{c}\text { resistência } \\
\text { (ohms) }\end{array}$ & 2503 & 2295 & 2125 & 1980 & 1850 & 1738 & 1639 & 1470 \\
\hline
\end{tabular}

As concentrações iniciais dos reagentes foram:

$\left[\mathrm{C}_{2} \mathrm{H}_{5} \mathrm{NO}_{2}\right]=0,1 \mathrm{~mol} . \mathrm{L}^{-1}$

$\left[\mathrm{C}_{5} \mathrm{H}_{5} \mathrm{~N}\right]=0,1 \mathrm{~mol} \cdot \mathrm{L}^{-1}$

$\left[\mathrm{l}_{2}\right]=0,0045 \mathrm{~mol} \cdot \mathrm{L}^{-1}$

Determine a ordem aparente da reação e a constante aparente em unidades apropriadas.

Supondo ordem um para a piridina e para o nitroetano, obtenha o valor da constante verdadeira.

6. A reação:

$$
\mathrm{C}_{6} \mathrm{H}_{5} \mathrm{CH}=\mathrm{CHCHCl}_{2}+\mathrm{C}_{2} \mathrm{H}_{5} \mathrm{O}^{-} \longrightarrow \mathrm{C}_{6} \mathrm{H}_{5} \mathrm{CH}=\mathrm{CHCl}+\mathrm{Cl}^{-}
$$

foi estudada espectrofotometricamente no comprimento de onda $2600 \AA$, onde o reagente (cloreto de cinamol) absorve, mas o produto não. Quando se estudou a reação em álcool absoluto, a $22,6^{\circ} \mathrm{C}$ e com concentrações iniciais: $\left[\mathrm{RCl}_{2}\right]=2,11 \times 10^{-5} \mathrm{~mol} \cdot \mathrm{L}^{-1} \mathrm{e}$ $[\mathrm{EtONa}]=0,547 \mathrm{~mol} . \mathrm{L}^{-1}$, foram feitas as seguintes leituras no espectrofotômetro:

\begin{tabular}{c|c|c|c|c|c|c|c}
\hline $\boldsymbol{t}$ (min) & 0 & 10 & 31 & 74 & 127 & 178 & 1200 \\
\hline $\boldsymbol{A}=\boldsymbol{\varepsilon} \boldsymbol{b c}$ & 0,41 & 0,38 & 0,34 & 0,26 & 0,18 & 0,14 & 0,01 \\
\hline
\end{tabular}

Calcule a ordem aparente, a constante de velocidade aparente e a constante verdadeira.

7. Os dados abaixo referem-se à decomposição do vapor de óxido de etileno em metano e monóxido de carbono, a $414,5^{\circ} \mathrm{C}$ :

\begin{tabular}{c|c|c|c|c|c|c}
\hline $\boldsymbol{t}$ (min) & 0 & 5 & 7 & 9 & 12 & 18 \\
\hline $\boldsymbol{p}$ (torr) & 116,50 & 122,56 & 125,72 & 128,74 & 133,23 & 141,37 \\
\hline
\end{tabular}

Mostrar que a decomposição segue uma reação de ordem 1, e calcular a constante específica de velocidade. 
8. A decomposição catalisada de $\mathrm{H}_{2} \mathrm{O}_{2}$ em solução aquosa é uma reação de ordem 1 , e foi estudada mediante a titulação de $\mathrm{H}_{2} \mathrm{O}_{2}$ não decomposta com uma solução de $\mathrm{KMnO}_{4}$. Determinar graficamente o valor da constante específica de velocidade.

\begin{tabular}{c|c|c|c|c|c|c}
\hline $\boldsymbol{t}(\boldsymbol{m i n})$ & 0 & 5 & 10 & 20 & 30 & 50 \\
\hline $\begin{array}{c}\text { volume de } \mathrm{KMnO}_{4} \\
\left(\mathbf{c m}^{3}\right)\end{array}$ & 46,1 & 37,1 & 29,8 & 19,6 & 13,3 & 5,0 \\
\hline
\end{tabular}

9. A decomposição do cloroformiato de triclorometila, em estado gasoso, em fosgênio acontece de acordo com a reação:

$\mathrm{ClCOOCCl}_{3}(\mathrm{~g}) \longrightarrow 2 \mathrm{COCl}_{2}(\mathrm{~g})$

A pressão do sistema foi medida em vários tempos, como mostra a tabela a seguir:

\begin{tabular}{c|c|c|c|c|c|c|c|c}
\hline $\boldsymbol{t}$ (min) & 0 & 51 & 206 & 454 & 751 & 1132 & 1575 & 2215 \\
\hline $\boldsymbol{p}$ (torr) & 15,03 & 15,48 & 16,74 & 18,57 & 20,33 & 22,27 & 23,98 & 25,89 \\
\hline
\end{tabular}

a) Determinar a ordem da reação.

b) Calcular sua constante específica de velocidade.

10. A velocidade da reação $A+B \rightarrow P$ foi seguida através de medidas da absorbância da solução em diferentes tempos, conforme a tabela:

\begin{tabular}{c|c|c|c|c|c|c|c|c}
\hline $\boldsymbol{t}$ (min) & 0 & 18 & 57 & 130 & 240 & 337 & 398 & $\infty$ \\
\hline Abs & 0,219 & 0,206 & 0,183 & 0,151 & 0,120 & 0,105 & 0,098 & 0,080 \\
\hline
\end{tabular}
$1,00 \mathrm{M}$.

Em outro experimento nas mesmas condições, mas com a concentração inicial de B igual a 2,00 $\mathrm{M}$ verificou-se que o valor da constante de velocidade observada teve um valor igual ao dobro do observado anteriormente.

a) Qual a ordem da reação?

b) Qual o valor das constantes de velocidade (observada e verdadeira)?

c) Qual o valor da meia vida da reação? 